Historic, Archive Document

Do not assume content reflects current scientific knowledge, policies, or practices. 

$62.63, \quad=1909$

FLOWERING TREES AND

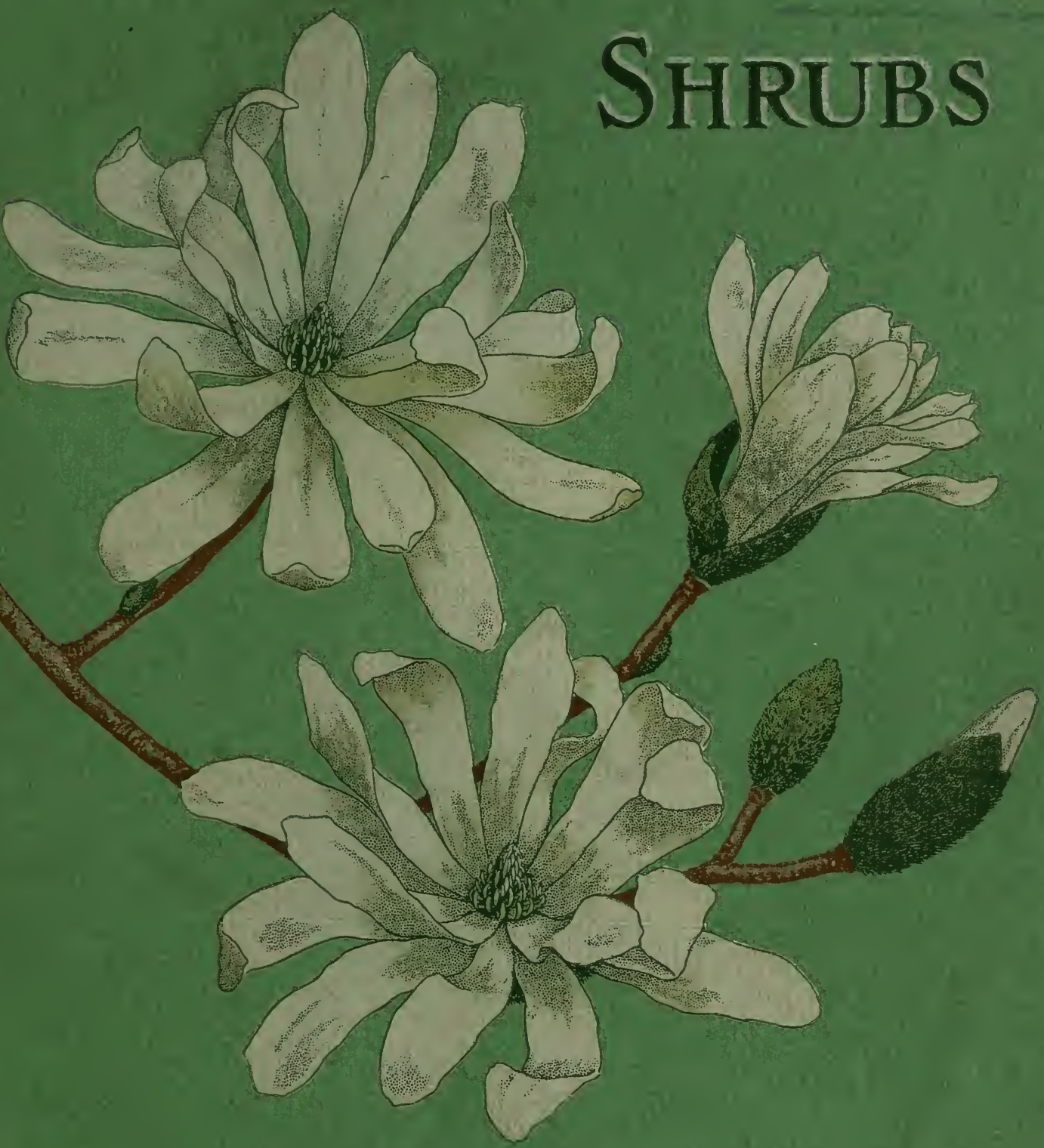

\section{BILTMORE NURSERY}

BILTMORE, NORTH CAROLINA 


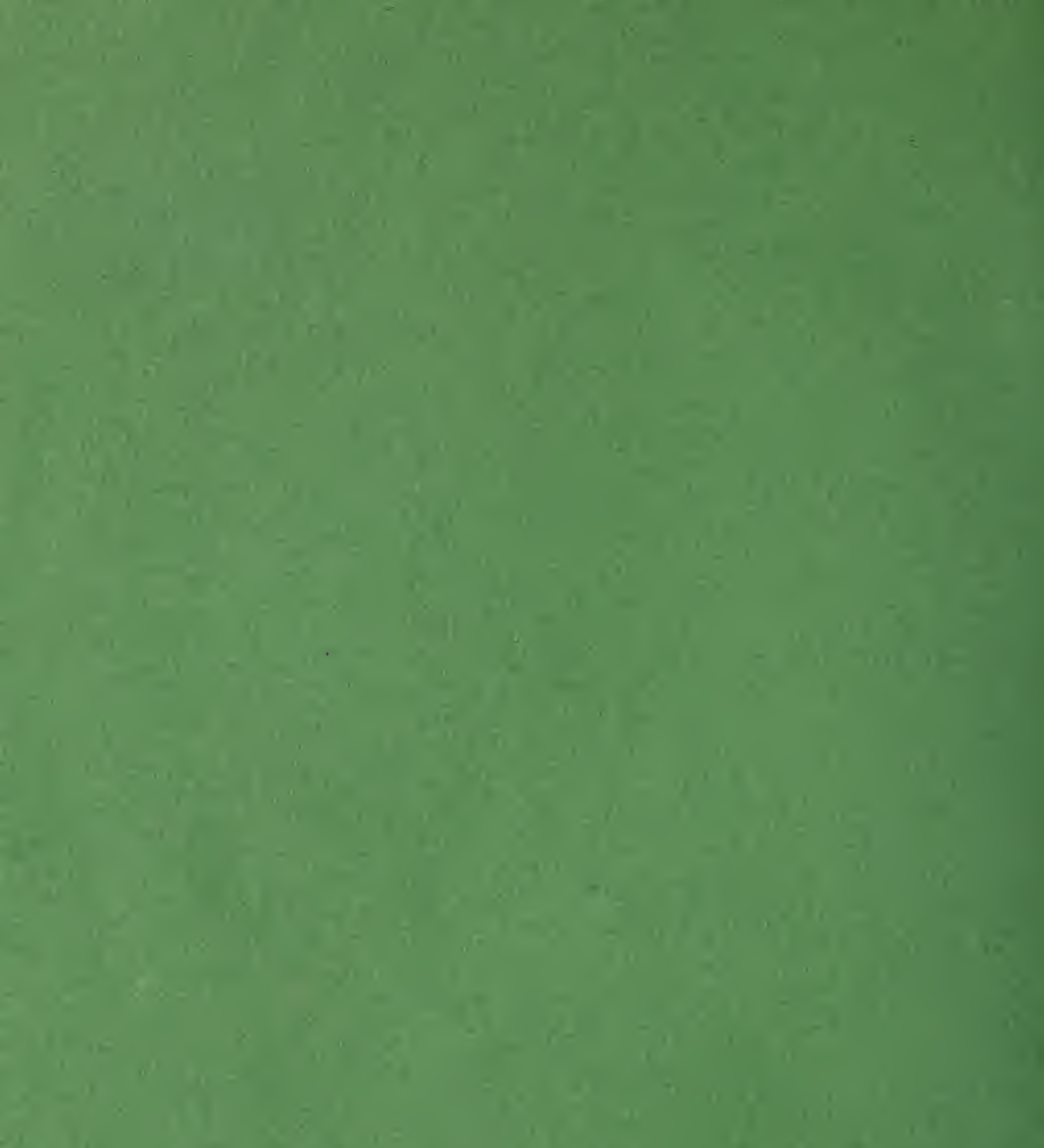

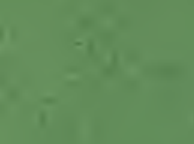

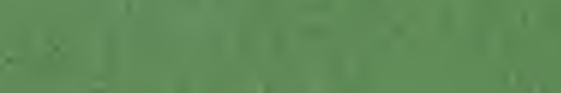

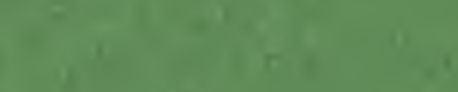

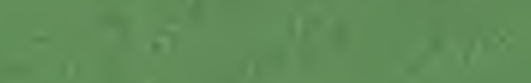
$8^{4}+x^{2}+x^{2}$

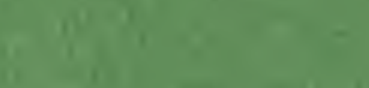

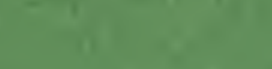

$14 x^{\prime}=-x$

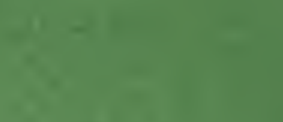

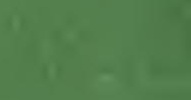

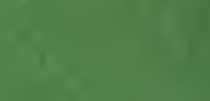
17

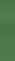

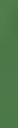
.

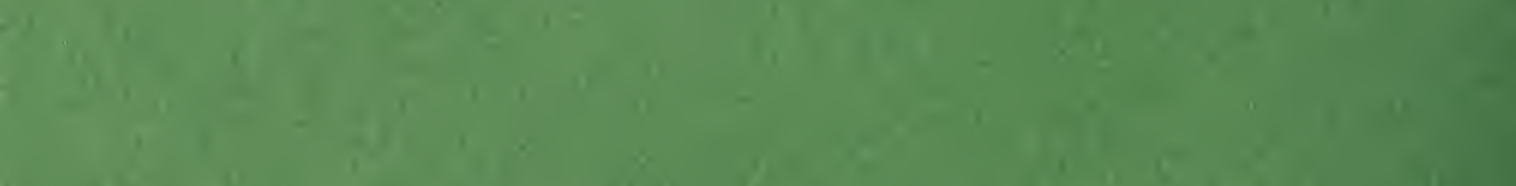

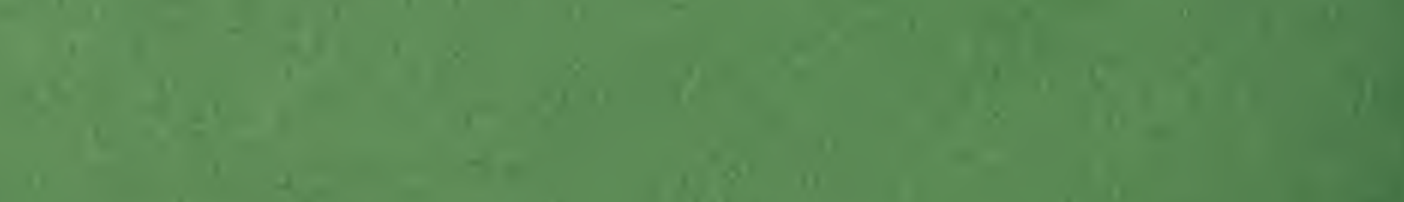

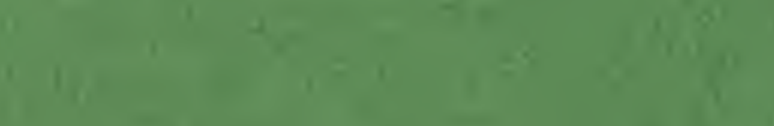

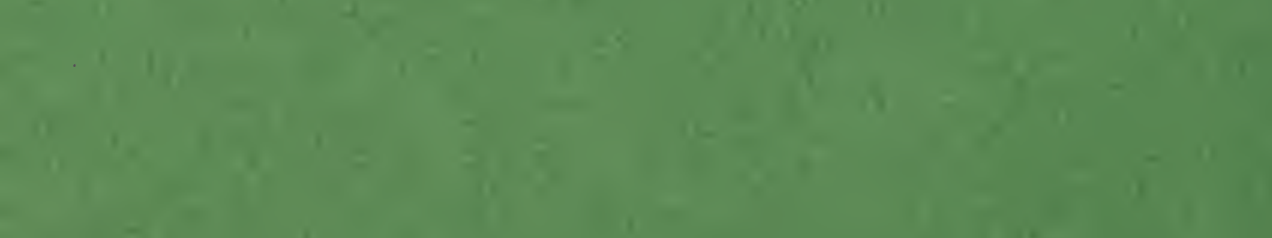

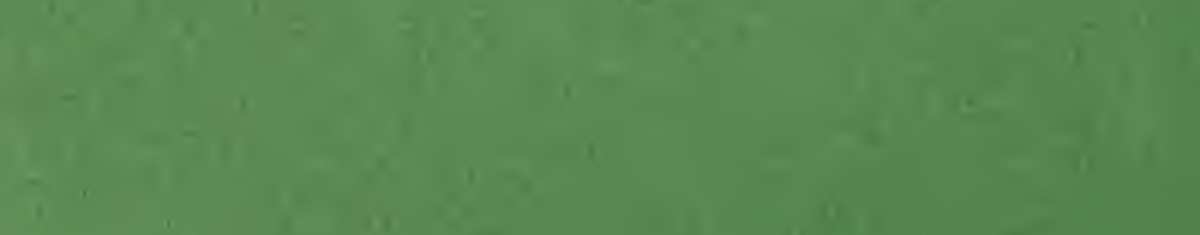
$-3 x^{2}{ }^{2}$ 


\title{
Flowering Trees and Shrubs
}

\section{BILTMORE NURSERY}

\author{
BILTMORE, N. C.
}




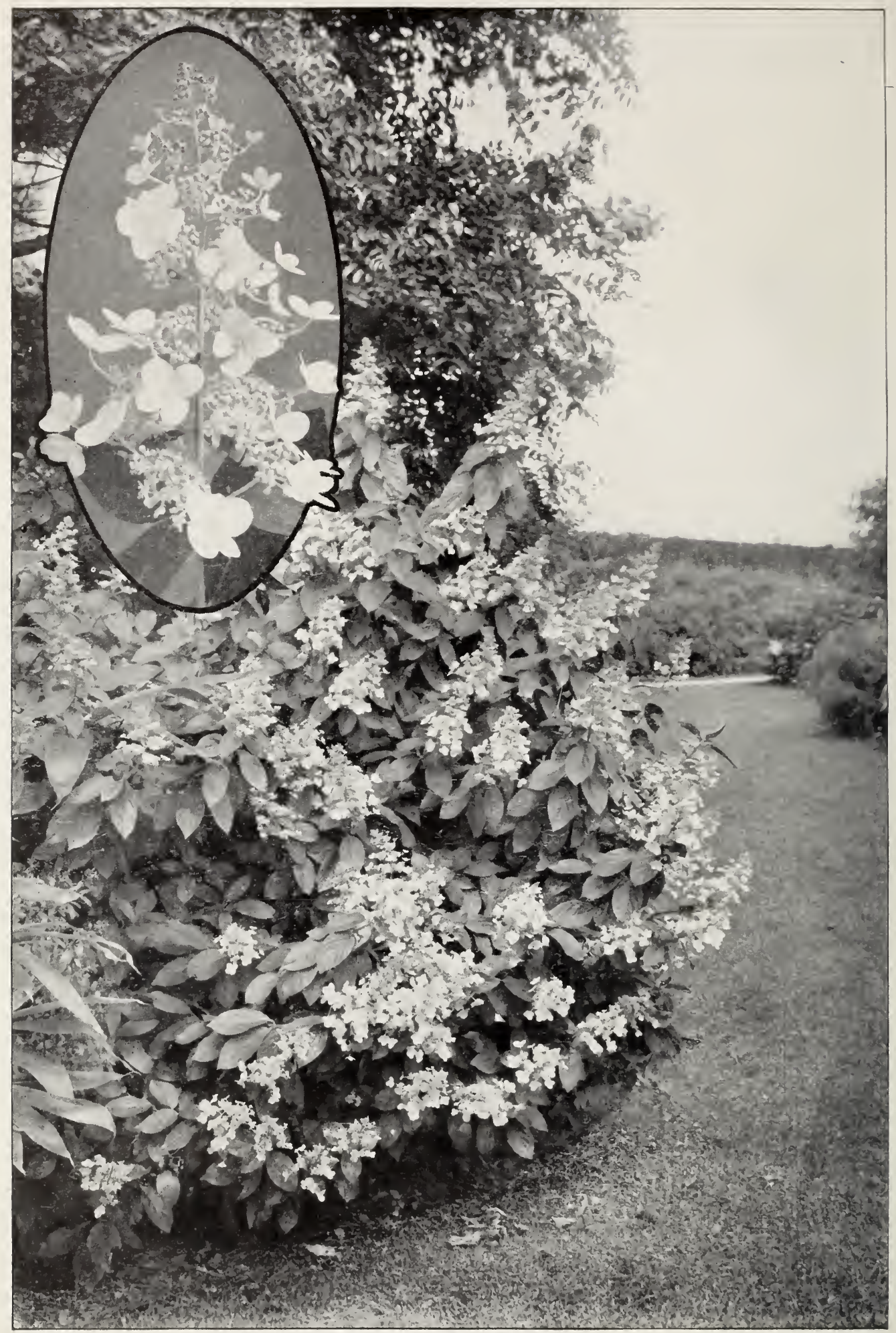

Hydrangea paniculata (see page 24 ) 


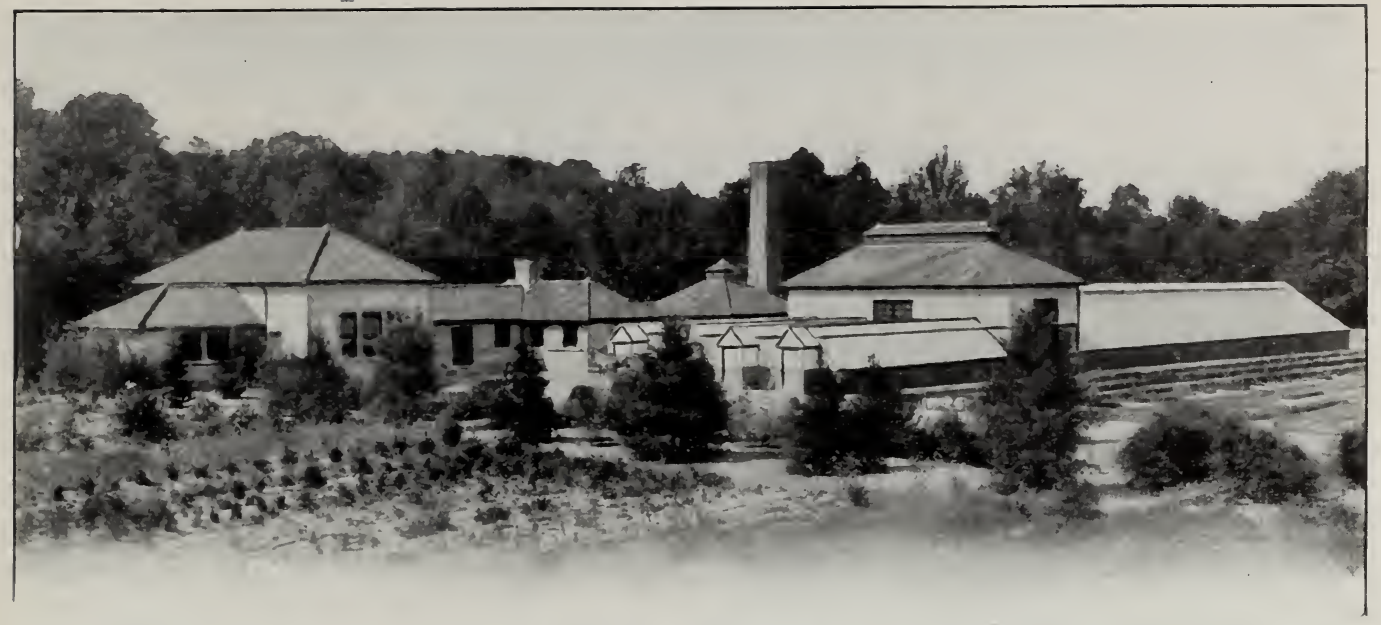

NURSERY BUILDINGS

\section{Introduction}

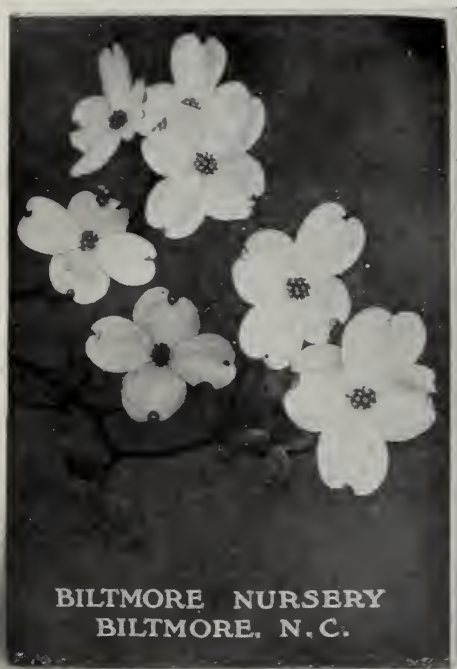

I

$\mathrm{N}$ this booklet, which we have titled "Flowering Trees and Shrubs," will be found descriptions, and, so far as space permits, laithful illustrations engraved from photographs of the foremost trees and shrubs producing showy blossoms-those that give transcendent floral beauty and lend to our lawns and gardens the bright and wholesome joy of profuse and fragrant Howers. No attempt has been made to exploit all of our large and consistent stock of "everything in ornamentals" in this publication; but rather have we aimed at helping the novice and amateur in finding easy access to the most noteworthy of flowering-trees and shrubs, and in aiding them to select with the least confusion or bewilderment the brightest gems among their numbers.

PATRONS AND PROSPECTIVE BUYERS who desire a more extended list than is herein presented, or are interested in other kinds of plants, such as Evergreens, both Coniferous and Broad-leaved; Shade Trees, Vines, Ornamental Grasses and Bamboos, Aquatic and Bog Plants, Hardy Ferns or Herbaceous Perennials, are invited to write for our complete cata$\log$, a book of about 2 o pages, replete with pictures and information concerning Biltmore plants and portraying one of the largest and most diversified collections of ornamentals in the world. The illustration opposite shows the cover design of our famous large catalogue. Free, on application, to any customer.

BILTMORE TREES AND PLANTS have been widely sought by discriminating buyers; the demand increasing to such an extent that we have been compelled to more than duuble our plantations and to prepare unique and attractive catalogs to place in the hands of enquiring friends and patrons who seek the best strains of ornamentals for their lawns and gardens. We appreciate the public confidence and the increasing patronage which has been bestowed upon us, and our efforts to uphold the high standard of our stock have been greatly stimulated by this encouragement.

BILTMORE NURSERY was established in I889. The experience of many years is blended in the production and handling of our plants. We have no connection whatever with any other nursery, and employ no agents, our entire business being transacted from our office at Biltmore, North Carolina.

OUR LOCATION is in the heart of the mountains of Western North Carolina, at elevations between two and three thousand feet above sea-level, where the temperature ranges from ninety degrees above to, in the instance of our higher fields, twenty degrees below zero. The main nursery is located on the northerly bank of the Swannanoa River, near its confluence with the French Broad and between the corporate limits of Biltmore and Asheville. The manager's office is in Biltmore, three minutes' walk from the terminus of the Asheville-Biltmore electric railway, and diagonally opposite the Southern Railway passenger depot. The superintendent's office is at the greenhouses, ten minutes' walk from the end of the trolley line. We invite inspection of our grounds any day except Sunday.

EXTENT AND CAPACITY. Nearly three hundred acres are devoted to the cultivation of trees and shrubs. Our greenhouses and coldframes cover an area of seventy-five thousand square feet, which, in connection with seed-beds to the extent of more than three acres, a large force of trained men and many varieties of carefully tilled soils, give us especial facilities for growing choice trees and plants on an extensive scale both in numbers and kinds. 
QUALITY OF STOCK. The variations in temperature peculiar to the Southern Allegheny region, its evenly distributed and bountiful rainfall, and rich but shallow soil, combine to produce a quality of stock remarkably superior in root-formation, thriftiness and hardiness. Biltmore Nursery is inspected annually by the State Entomologist and a certificate pronouncing the stock free from all insects designated as dangerous pests, and apparently healthy in every respect, will be attached to every shipment.

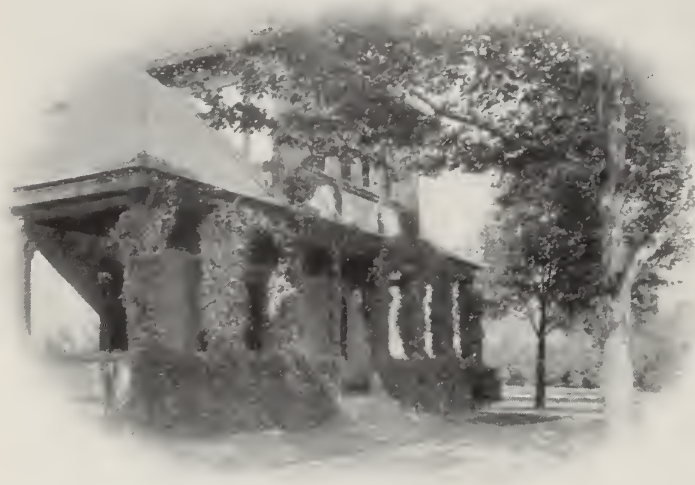

Main office II'e are prepared to fumigate with hydrocyanic gas all or any nursery stock when state laws or customers require such treatment.

PLANTING PLANS AND HORTICULTURAL QUESTIONS. VVe are pleased to answer inquiries from friends or patrons concerning what to plant, how to plant and when to plant. Our experience is at your command. Not only are we prepared to give advice, supply names of trees, shrubs and plants, either cultivated or wild, or to prescribe for plant diseases or attacks of insects, but we will gladly undertake, at small cost, to prepare plans for beautifying the home surroundings, showing a pleasing arrangement of paths and drives combined with an artistic grouping of trees and shrubs.

BILTMORE TREES AND PLANTS are growing from Maine to California and from Canada to Mexico, besides several countries across the seas. From the wording of the descriptions it is an easy matter to select plants adapted to the local conditions of the average planter, whether it be a locality where severe cold reigns in winter, or one where warmer sun prevails.

SHIPIENTS. IVe have suitable plants of each grade of all the varieties listed. Such plants have been frequently transplanted, are shapely and select specimens, and represent honest values. They may be sent safely to any point having transportation facilities. Prepaid shipments are, of necessity, made up of smaller plants than those traveling at purchasers' expense; but invariably they are robust, wellestablished field-grown plants and eminently satisfactory where the inconvenience or expense of heavier shipments is a deterrent. IVe reserve the right to forward prepaid orders by express or mail, and in the instance of packages weighing in excess of one hundred pounds, to effect delivery by freight.

OUR RESPONSIBILITY. IVe refer you to any bank or bankers in Asheville, N. C. We guarantee safe arrival and satisfactory condition of all shipments, unless, from the lateness of the season or extreme causes, we write for consent to waive responsibility. We are most careful to have all plants correctly labeled, and hold ourselves prepared to replace, on proper proof, all that may prove untrue to label, or to refund the amount paid therefor; but it is understood that, in case of error on our part, we shall at no time be held responsible for a greater amount than the original price of such plants.

PACKING. The utmost care will be used in digging and preparing the plants for shipment. There are no charges for packing or packing-cases, or for delivery to our freight or express depots, except in the instance of shipments to foreign countries, where the preparation is often an important item of expense.

RATES AND PRICES. The prices quoted in this catalog are net, and apply to unit quantities; but six plants of any one kind will be furnished at five times the single rate, and a dozen plants of any one kind at ten times the price for each plant.

PACKING SEASON. We ship from October I to May I, with the usual interruptions during winter.

CARE OF STOCK ON ARRIVAL. Promptly on arrival the trees or plants should be unpacked and planted, or else the roots should be protected from sun or air by covering with moist earth. If the ground is frozen outside, or the packing material in the cases frocen, store the original package in a cool, moist cellar until the conditions are favorable for handling. Care should be taken in choosing soil and environment to the end that success may reasonably follow your labors in planting.

CATALOGS SENT UPON REQUEST. We will gladly mail catalogs to any one interested in plants, or to friends into whose hands you would care to place a copy.

TREES AND PLANTS AS ANNIVERSARY PRESENTS. Orders are frequently received from patrons to send plants $t$ special addresses as gifts or amniversary presents, with requests to convey to the recipients the proper form of acknowledgement, and in due time the items of stock selected. All such orders will be most carefully handled, and the plants definitely reserved for forwarding during the planting season.

CONCERNING BILTMORE PLANTS. We are frequently asked if plants grown in the North Carolina Mountains are adaptable to the climatic and other conditions existing in many sections of the country. They are, indeed, peculiarly resistent to changes of environment. Mother Nature develops her sturdiest children on the mountain plateaus, and they carry the vigor of the hills with them when transplanted to the plains and valleys. Experience has shown that trees, shrubs and plants grown in high elevations are remarkably hardy and vigorous when transplanted to lower levels, growing year after year in the new locations with undiminished vigor. A trial order, if nothing more, will result in lasting pleasure.

BILTMORE NURSERY, Biltmore, North Carolina 

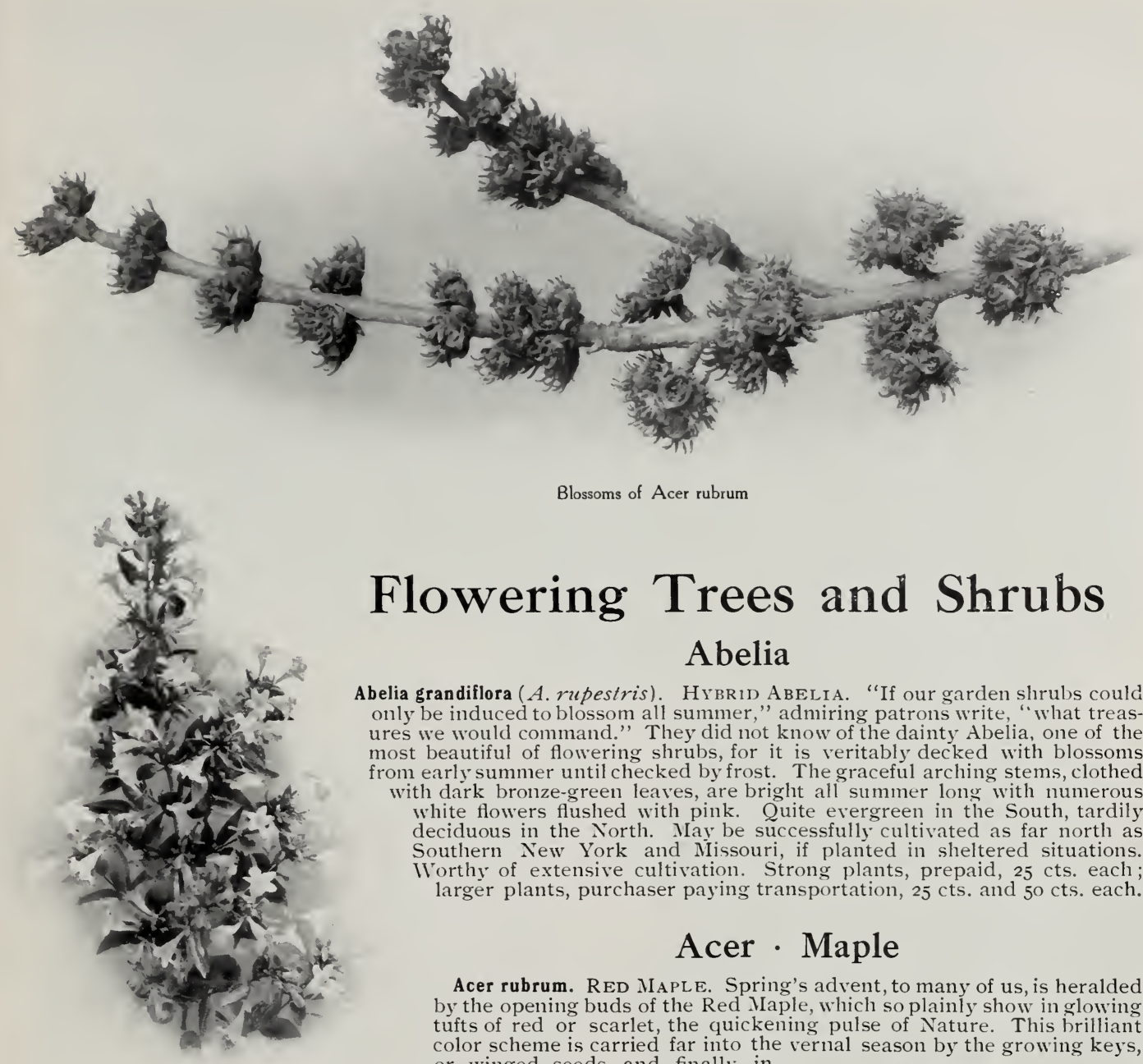

Blossoms of Acer rubrum

\title{
Flowering Trees and Shrubs
}

\begin{abstract}
Abelia
Abelia grandiflora (A. mpestris). HYBRiD ABELIA. "If our garden shrubs could only be induced to blossom all summer," admiring patrons write, "what treasures we would command." They did not know of the dainty Abelia, one of the most beautiful of flowering shrubs, for it is veritably decked with blossoms from early summer until checked by frost. The graceful arching stems, clothed with dark bronze-green leaves, are bright all summer long with numerous white flowers flushed with pink. Quite evergreen in the South, tardily deciduous in the North. May be successfully cultivated as far north as Southern New York and Missouri, if planted in sheltered situations. Worthy of extensive cultivation. Strong plants, prepaid, $25 \mathrm{cts}$. each; larger plants, purchaser paying transportation, $25 \mathrm{cts}$. and $50 \mathrm{cts}$. each.
\end{abstract}

\section{Acer - Maple}

Acer rubrum. RED MAPLE. Spring's advent, to many of us, is heralded by the opening buds of the Red Maple, which so plainly show in glowing tufts of red or scarlet, the quickening pulse of Nature. This brilliant color scheme is carried far into the vernal season by the growing keys, or winged seeds, and finally, in autumn, the leaves transform into a crown of ruddy splendor. A

handsome and attractive tree of

Abelia grandiflora great hardiness. Thrifty young plants, prepaid, $25 \mathrm{cts}$. each ; larger sizes, purchaser paying transportation, $25 \mathrm{cts}$., $50 \mathrm{cts}$. and \$1 each.

\section{Esculus . The Horse-Chestnuts and Buckeyes}

Vigorous, hardy and symmetrical trees, the larger species of which are widely planted for shade, both on lawn and street, being extremely adaptable to the conditions afforded them. Their handsome flowers, aptly compared with hyacinths, are disposed in long and showy panicles, boldly contrasted against the deep green foliage. The following are among the best and most useful species:

AEsculus hippocastanum. EUROPEAN, OR COMMON HORSEChestiut. Flowers white, tinged with red, in loose clusters 8 to 12 inches long. The large attractive seeds are the delight of children. A large tree with many good qualities, and one that has been most successfully used in some sections of the North for street planting. Thrifty young plants, prepaid, $25 \mathrm{cts}$. each; stronger trees, purchaser paying transportation, $25 \mathrm{cts}$., $65 \mathrm{cts}$. and \$I each.

AE. hippocastanum flore pleno. DOUBLE-FLOWERED HORSECHEstiut. A form with double white flowers of surpassing beauty. Bears no fruit. The flowers are more durable than those of the single-flowered kinds, thereby extending the blossoming period for several days. A large symmetrical tree. Thrifty young plants, prepaid, $40 \mathrm{cts}$. each; stronger trees, purchaser paying transportation, $40 \mathrm{cts}$., $75 \mathrm{cts}$. and $\$ \mathrm{I} .50$ each.

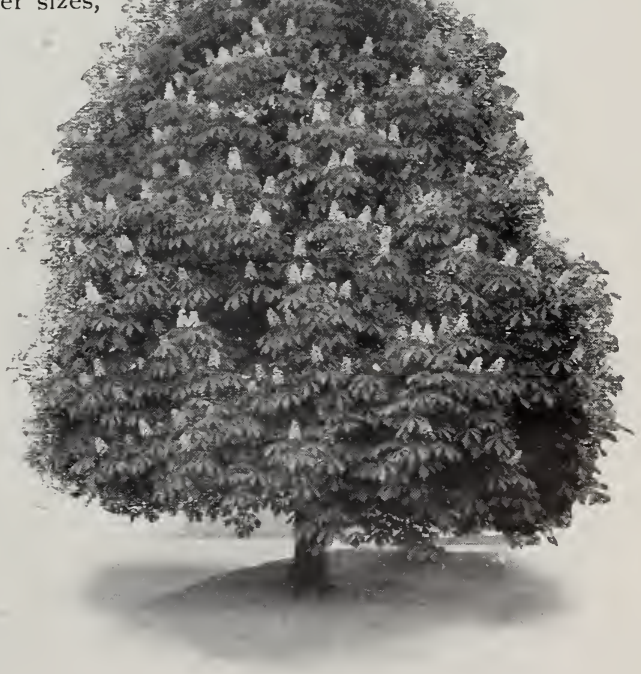

Horse-Chestnut Tree in bloom 


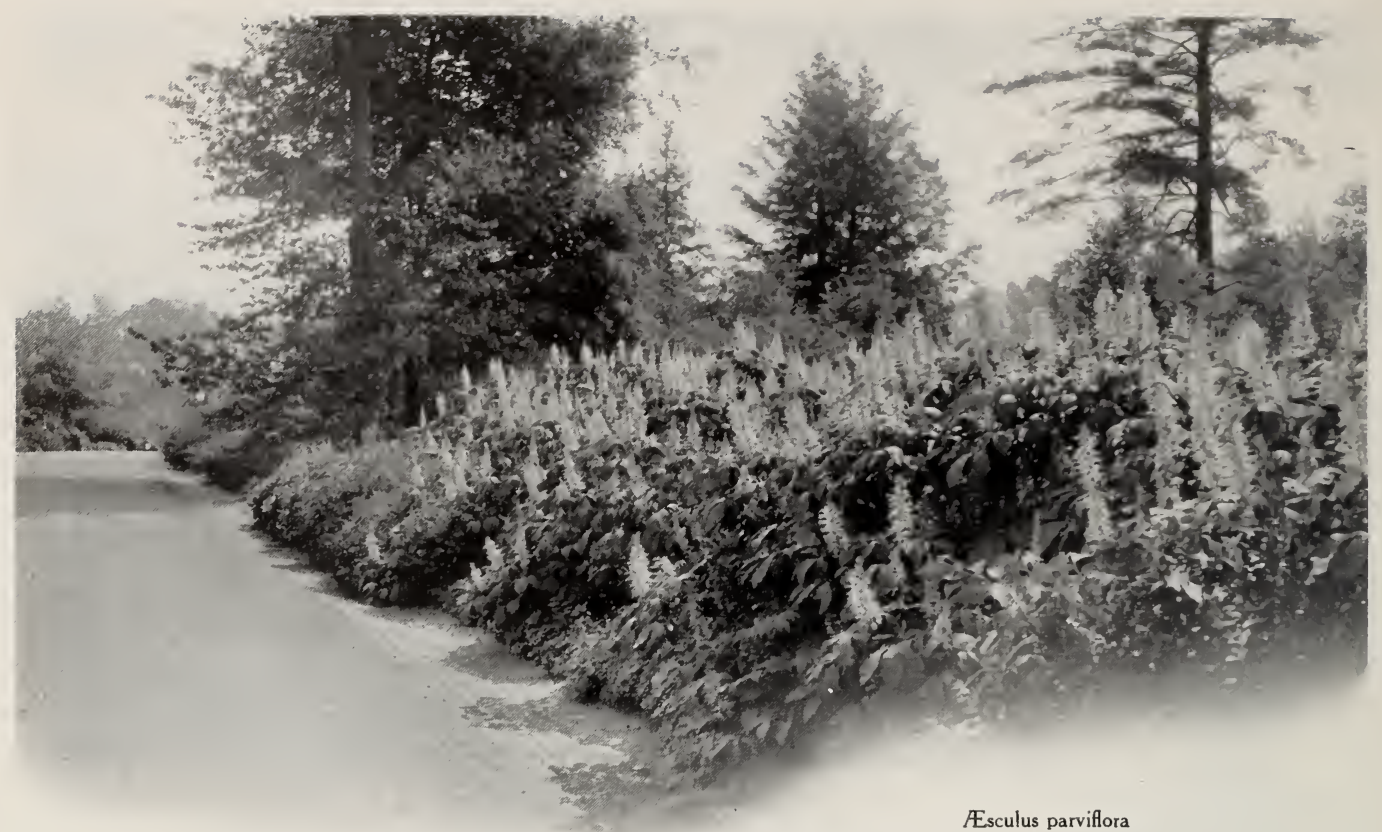

Esculus, continued

AEsculus parviflora (A. macrostachya). LongRACEMED HORSE-CHESTNUT. Charming and unique, this showy shrub deigns to surpass in length of inflorescence all its prototypes, producing its creamy white flowers in panicles io to 15 inches long. Very attractive. Thrifty young plants, prepaid, 5o cts. each ; larger sizes, purchaser paying transportation, $50 \mathrm{cts}$. and 75 cts. each.

A. rubicunda. RED-Flowering HORSE-Chestnut. An extremely handsome tree, producing large panicles of flowers varying in color tone from scarlet to red. Commonly planted and a great favorite. Thrifty young plants, prepaid, 40 cts. each; larger trees, purchaser paying transportation, 40c., 75c. and $\$ \mathrm{I} .50$ each.

\section{Albizzia}

Albizzia julibrissin (Acacia nemu). Mimosa Tree. A remarkably beautiful and very floriferous tree developing a low flat-topped crown. Everywhere associated with Southern gardens, and lending to them, by graceful feathery foliage and showy acacia-like flowers of pink and yellow, a subtle and lasting charm. Hardy

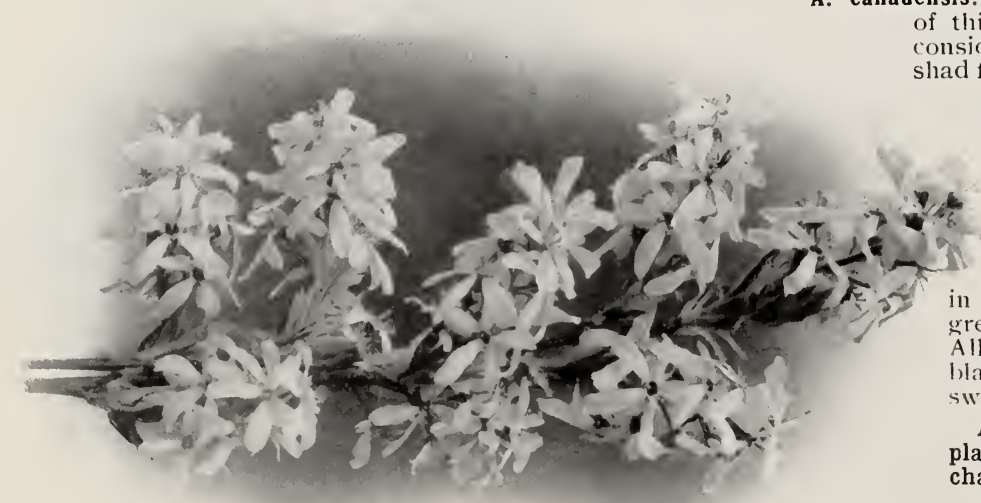

Amelancier botryapium
Albizzia, continued

as far north as Washington and Memphis. Thrifty young plants, prepaid, 25 cts. each; stronger plants, purchaser paying transportation, $25 \mathrm{c}$. and $50 \mathrm{c}$, each.

\section{Amelanchier · Service Trees, Shadbush and Juneberries}

The thrills of joyous life and hope awakened by spring's first flowers revive within us the gardening impulse - the inherent and universal love to cultivate the beautiful. Among the very early-flowering subjects few indeed surpass the dainty Amelanchiers, appearing, as they often do, with a profusion of nodding racemose flowers of purest white. All of the species are extremely hardy, the following being especially recommended:

Amelanchier botryapium. SERvice BERRY. JUNFBERRY. A remarkably floriferousslender tree, possessing rare grace and beauty; the precocious flowers always demanding admiration.

A. canadensis. SHADBLSH. The blossoming period of this beautiful small tree has long been ensidered an index to the movement of the of the Atlantic seaboard, and hence its name, Shadbush. It is a meritorious garden subject, responding to the first call of spring.

A. vulgaris. EUROPEAN JUNEBERRY: An attractive free-growing shrul, producing a profusion of dainty blossoms. It is an uncommon object in our gardens, but decidedly wortly of greater recognition and wider planting. All of the species bear quantities of blueblack or purplish berries which are juicy, sweet and very palatable.

Any of the Amelanchiers, young thrifty plants, prepaid, 25c. ea.; larger sizes, purchaser paying transportation, $25 \mathrm{c}$. and $50 \mathrm{c}$

The 50 deciduous small trees arrived all right a couple of days ago in good condition and have been planted.SAMUEL L. PAR1 ï, Southampton, I. I., Apr. 17, 1908 . 


\section{Amorpha . The Lead Plant and Indigo Bush}

Hardy, free-flowering shrubs, with feathery foliage, adapted to sunny situations. The unusual form and color of the flowers invariably attract attention and admiration. Very valuable for border plantations or for massing on rocky banks or slopes, where their graceful outlines and bright leaves lend most pleasing effects.

Amorpha canescens. LEAH PLANT. A low dense shrub of silvery aspect, both unique and charming in appearance. Flowers light blue, produced in numerous clustered racemes. Splendid for rock gardens.

A. montana. Mountain Indigo. A smooth muchbranched shrub, growing 4 to 6 feet high. The bright green leaves have a decided purplish tone and glaucons bloom when young. Flowers violet-purple, in clustered racemes 4 to 6 inches long. This is the handsomest of all of the species of Indigo Bushes, and is a remarkably meritorous, though uncommon plant.

Either of the above, strong plants, prepaid, $25 \mathrm{cts}$. each; larger sizes, purchaser paying transportation, 25 cts. and $50 \mathrm{cts}$. each.

\section{Aralia . The Angelica Trees}

The luxuriant, tropical aspect of these notable plants is extremely impressive and charming. The mammoth compound leaves, often 3 or 4 feet long; the huge panicles of creamy white flowers, like myriad flecks of foam; and, in autumn, the wealth of dark purple berries disposed in numerous globelike clusters-these constitute some of the glories of the Aralias. They are small trees or bushes, relatively hardy, with the larger or tree-like stems surrounded at the base by smaller, unbranched shoots.

Aralia chinensis. The Chinese Angelica Tree. Generally regarded as the more robust and hardier of the two kinds here listed. Such vigor and sturdy life as is possessed by this subject is truly inspiring. The flowers appear in late summer from the ends of the shoots or branches; the berries hanging until after frost or awaiting only the appetites of feathered songsters.

A. spinosa. Angelica Tree. Hercules' Club. The stout, prickly stems are indeed like giant clubs and the proverbial "Big Stick" need not lack a natural source of origin. Both species are seen at their best in connection with plantations of other shrubs or small trees, to which they add a decided and happy emphasis.

Either of the above, strong plants, prepaid, $40 \mathrm{cts}$. each; larger sizes, purchaser paying transportation, 40 cts. and 60 cts. each.

\section{Azalea . The Azaleas}

Rivals for splendor, the Azaleas seemingly surpass, so gorgeous are the floral crowns that overspread their branches. In colors soft and pure, or flaming bright in dazzling tones, their flowers present a display so extraordinary and commanding that they are universally admired. A location affording partial shade and moist, well-drained soil should be selected. A liberal mulch of forest leaves, held in place by a sprinkling of earth, is also advantageous. Under such conditions, these charming plants will thrive and reward your efforts with a lavish floral tribute.

Azalea amoena. Hardy Evergreen Azalea. A bushy shrub with small green leaves which change in winter to a rich bronze or coppery brown. In spring the whole plant is covered by a wealth of claret-purple flowers which continue to open for a period of two or

\section{Azalea amœna, continued}

three weeks. Beautiful low hedges may be made by planting in single line, or bolder results may be obtained by massing or grouping. Hardy as far north as Missouri and New York. Very highly recommended.

A. arborescens. Fragrant AzALEA. A hardy deciduous shrub with bright green foliage which assumes a rich shade of crimson in autumn. Flowers sweetscented, white tinged with rose, and with long exserted red style and stamens. One of the easiest Azaleas to cultivate. Very showy and desirable.

A. gandavensis. GHent Azalea. Of the deciduous Azaleas this form is classed among the most floriferous and produces the largest flowers. The blossoms are borne in profuse clusters in spring, literally covering the branches with their varied and gorgeous hues, which range chiefly in shades of yellow, orange and red. Hardy.

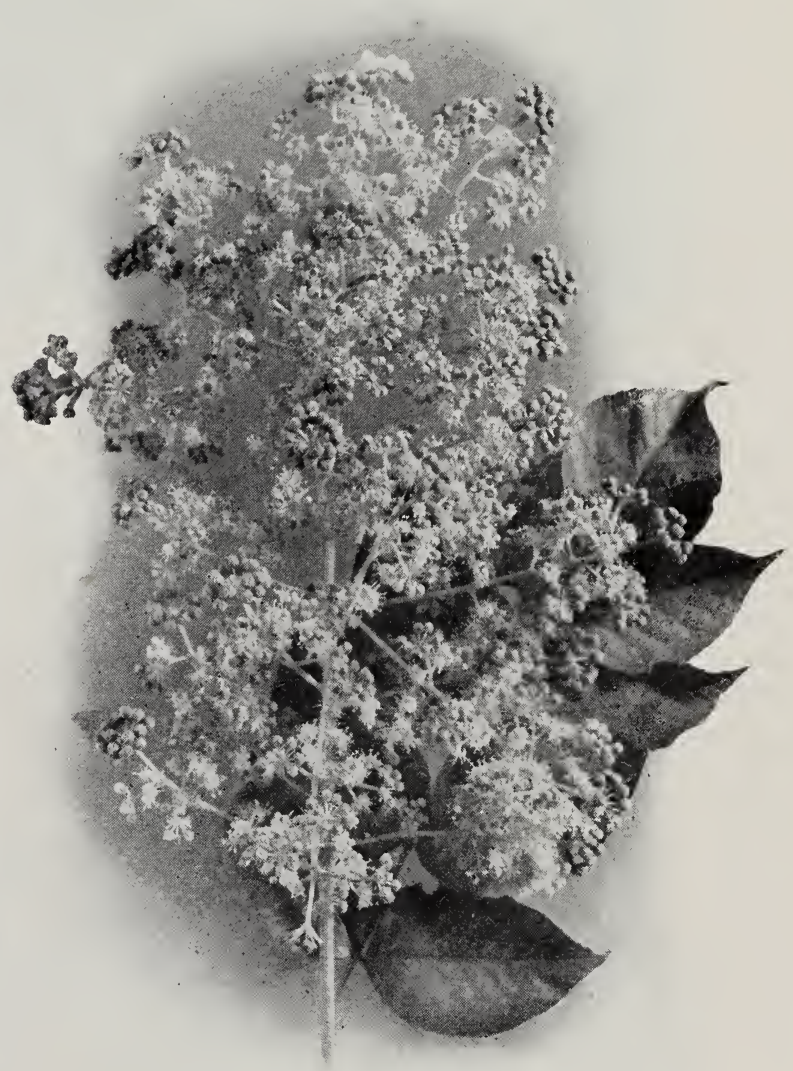

Aralia spinosa

A. indica. Indian Azalea. Without doubt one of the most handsome and showy of flowering shrubs, thriving without protection in the Southern and Pacific States. The colors of the flowers range from pure white and shades of purple, crimson and salmon, to mottled, blotched and striped forms, both in single- and doubleflowered varieties. The pride of Southern gardens.

A. lutea ( $A$. calendulacea). Flame-Colored AzALEA. One of the hardiest and most gorgeous of the deciduous Azaleas, producing in late spring profuse clusters of large flowers ranging from flame-color through shades of red and yellow. A most valuable plant, remaining in bloom for several weeks. 


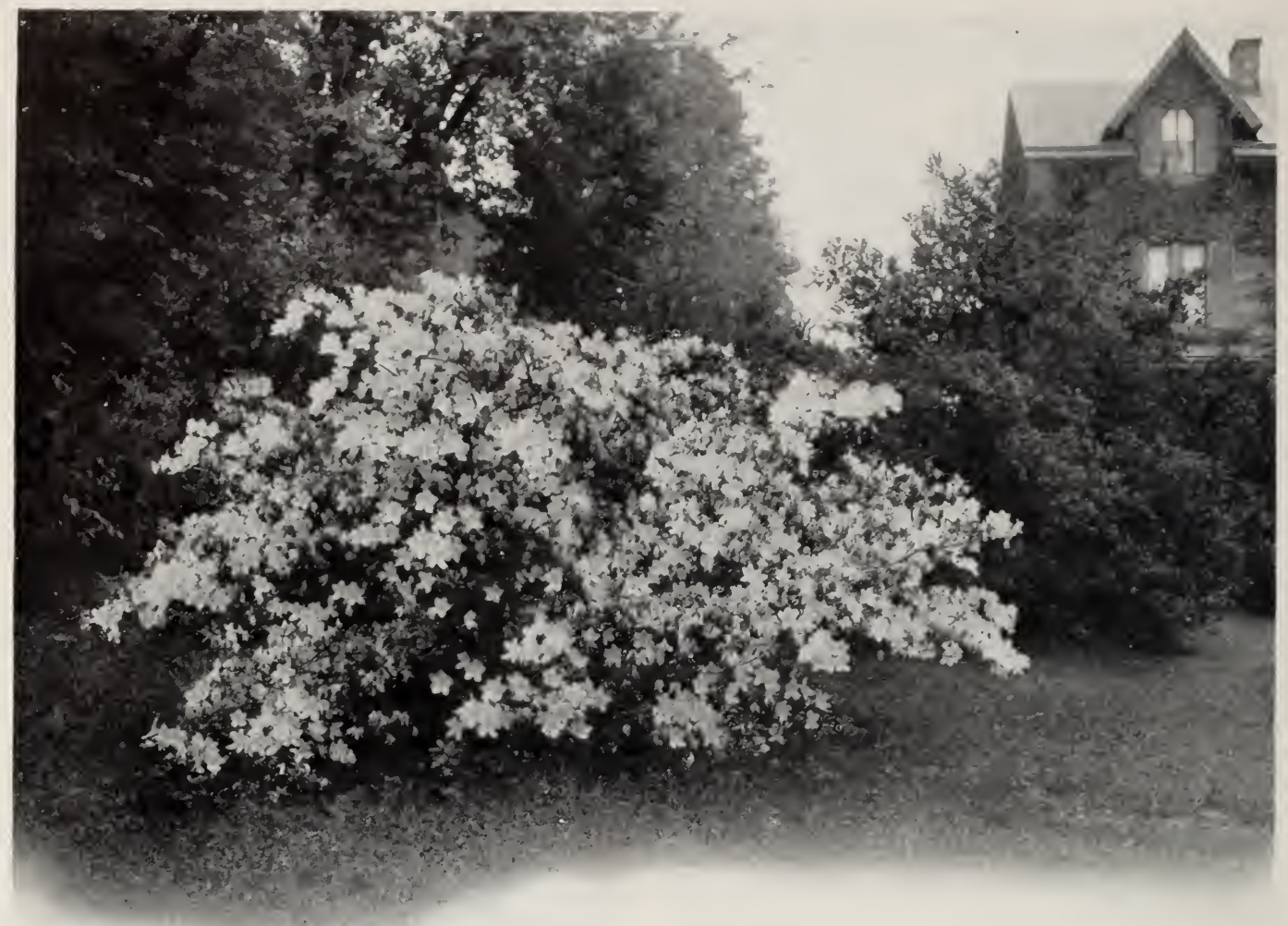

An Azalea in bloom

\section{Azalea, continued}

Azalea mollis. JAPANESE AzALEA. A hardy deciduous shrub with flowers rivaling in size and substance those of the Indian Azalea. Like the Ghent Azalea, which it simulates, this beautiful form is literally a mass of flowers in spring, with colors ranging in tones of yellow, orange and red.

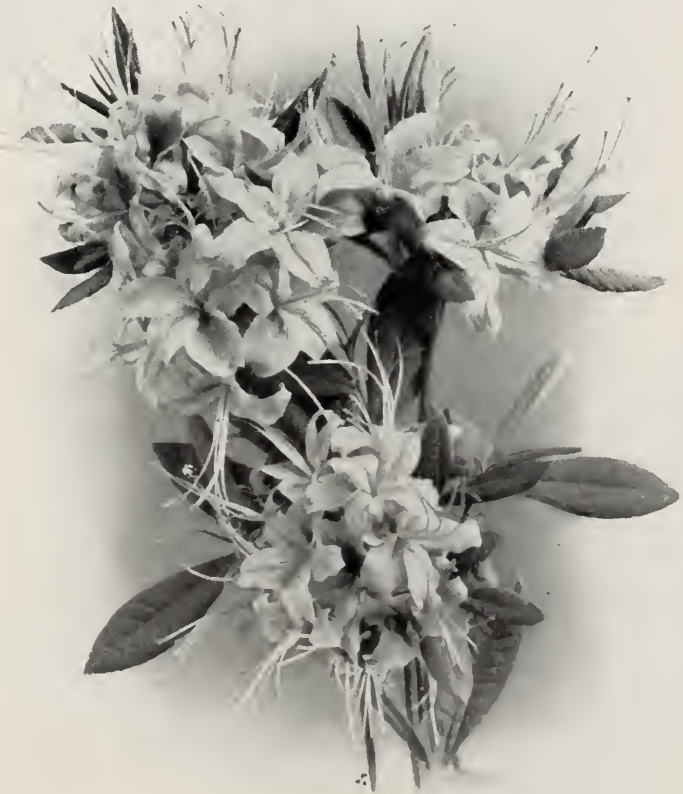

Azalea lutea (see page 7 )
Azalea nudiflora. PIXkSTER Flower. A handsome free-flowering deciduous shrub of renowned hardiness. The blossoms appear in early spring before the leaves, deep pink, profuse and very showy. The extreme earliness and beauty of the flowers commend it to the planter.

A. obtusa ( $A$. hinodigeri). HARDY INDIAN AzALEA. A splendid vigorous type and an excellent companion plant for the $A$. amoena. The profuse showy flowers are of a bright rose-purple color, and literally cover the branches with a fabric of radiant beauty. The dense evergreen foliage is beautifully toned with bronze and copper shades. A decided acquisition and remarkably hardy.

A. vaseyi (Rhododendron vaseyi). CAROLINA AzALEA. A distinct and remarkably free- $f$ - 1 wering hardy shrub of extreme rarity and beauty. The profuse flowers are of an exquisite shade of pink or rose, and appear before the leaves unfold. In autumn the foliage assumes a deep rich tone of vinous red or crimson. Unique.

A. viscosa. Small White Azalea. A low hardy shrub blossoming profusely at an early age. Flowers fragrant, pure white, expanding later than those of other varieties. Strong plants, prepaid, $50 \mathrm{cts}$. each; larger sizes, purchaser paying transportation, 5o cts. and $75 \mathrm{cts}$. each.

Except where noted, any of the above Azaleas, strong plants, prepaid, 75 cts. each; larger sizes, purchaser paying transportation. 75 cts. and $\$ 1$ each.

SPECIAL OFFER A collection of six Azaleas, no two alike, our selection of varieties, chosen with due regard to the requirements of your locality, prepaid strong plants, $\$ 3.75$; larger sizes, purchaser paying transportation, $\$ 3.75$ and $\$ 5$.

Shrubs ordered at hand and I am very much pleased with them and thank you for the choice complimentaries. They are above the average and you could not have sent me anything that I could have appreciated more. Very truly, E. T. HART (The Hart \& Houston Store), Johnson City, Tenn., March 15,1908 . 


\section{BILTMORE, N.C. T N W}

\section{Berberis . The Mahonia and Barberry}

These attractive shrubs are of inestimable value as garden subjects, not alone for their pretty yellow. flowers, but for their peculiar and characteristic foliage and showy fruits. While there are many species in cultivation, each with special adaptation or type of beauty, the following are particularly noteworthy for their flowers:

Berberis aquifolium (.Mahonia aquifolium). OREGON GRAPE. MAHONIA. A handsome ornamental shrub with evergreen, spiny-toothed leaves. Flowers yellow, in dense clusters in early spring, expanding just at the time when we prize so dearly the first blossoms. Berries blue, or nearly black. In winter the foliage assumes a rich bronze or coppery tint that is truly. charming. Strong plants, prepaid, 50 cts. each; larger sizes, purchaser paying transportation, 50 cts. and 75 cts. each.

B. vulgaris. EUROPEAY BARBERRY. A sturdy shrub of renowned hardiness. Flowers golden yellow, in profuse clusters in early spring: very showy. The bright scarlet berries remain on the upright or arching branches throughout the winter, lending cheer and brightness to the scene. In autumn the foliage assumes gorgeous tones of glowing crimson. An old-lime favorite. Strong plants, prepaid, 15 cts. each; larger sizes, purchaser paying transportation, I5 $_{5} \mathrm{cts} ., 25 \mathrm{cts}$. and 35 cts. each.

\section{Bignonia}

Bignonia crucigera ( $B$. capreolata). Cross Vixe. A handsome hardy vine, often climbing 50 feet high, with a drapery of bronze-green persistent foliage. Flowers trumpet-shaped, reddish orange on the exterior, yellow within, large and very showy, displayed in axillary clusters in late spring and early summer. Splendid for climbing on walls or trunks of trees, or for training on arbors or trellises. Try to avoid a southern exposure in choosing the planting site. Strong plants, prepaid, $25 \mathrm{cts}$. each; larger plants, purchaser paying transportation, $2.5 \mathrm{cts}$. and $50 \mathrm{cts}$. each.

Plants on former order were received in good condition. They are the best mailing specimens I hare erer seen. Yours very truly, RICHARD NoYe, JR., 50 Lake View Ave., Buffalo, N. Y., April 7, I908.

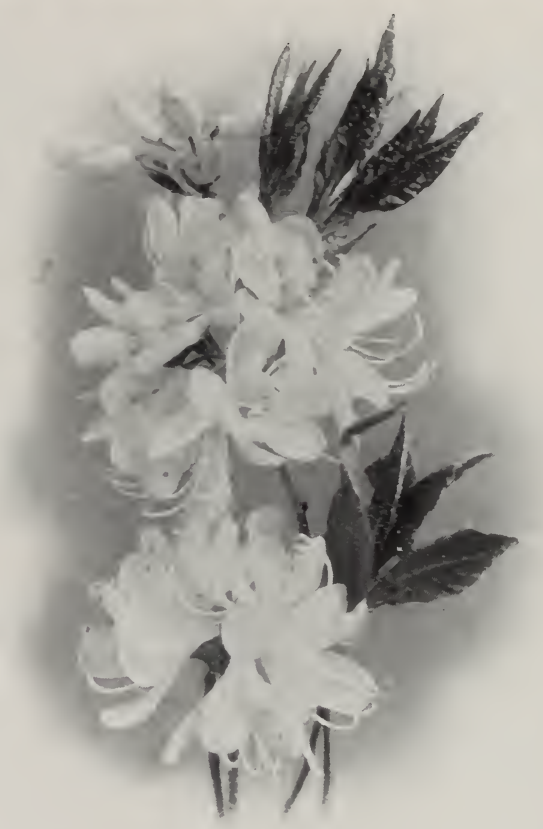

Azalea vaseyi (see page 8 )

\section{Buddleia - The Buddleias}

The rare grace and beauty of these comparatively little-known shrubs calls forth many exclamations of surprise and delight. They are remarkably interesting and free-flowering, producing blossoms throughout the summer season. In the colder sections, where they are not altogether hardy, a sheltered situation should be selected, preferably one affording a sunny exposure, loamy well-drained soil and abundant fertility.

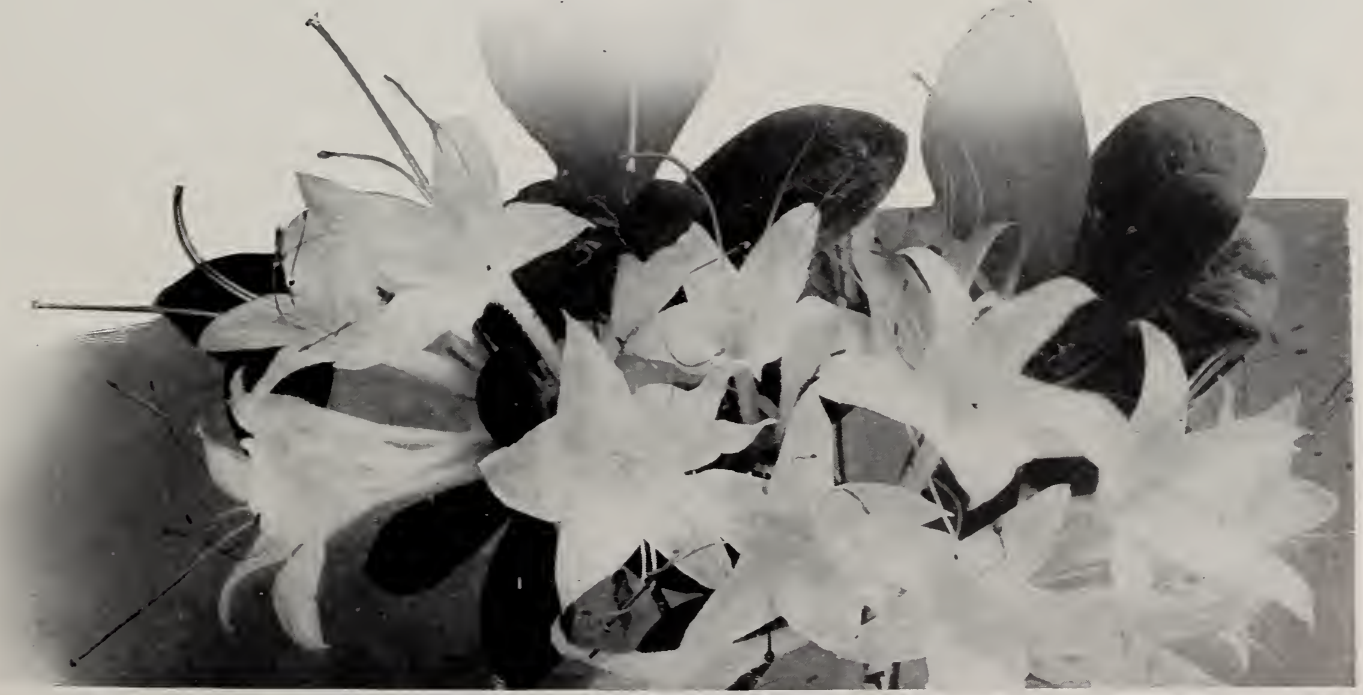

Azalea arborescens (see page 7 ) 


\section{BILTMORE NURSERY T NE}

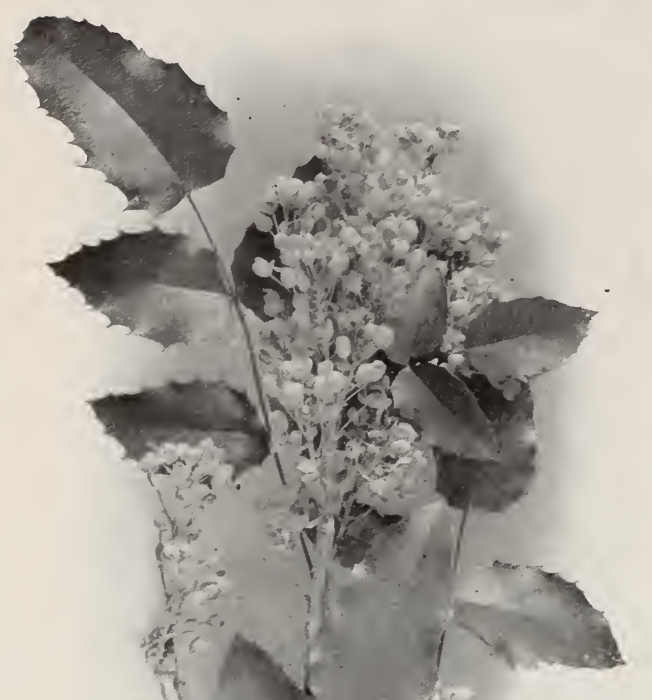

Buddleia, continued

Buddleia lindleyana. CHIx̌se BUdDleia. A charming shrub with very dark green leaves, usually attaining a height of 5 to 8 feet. Flowers violet-purple, in dense arching racemes 4 to 8 inches long. This has proved to be the hardiest species at Biltmore, and retains its foliage until very late in the season. Invites comment wherever seen.

B. variabilis. FRAGRANT BLDDLEIA. Although of comparatively recent introduction, this graceful shrub has gained many enthusiastic admirers by reason of the profuse showy inflorescence which literally bends the shoots and branches with floral burdens. Flowers lilac, with an orange-yellow spot in the throat, produced in dense terminal panicles 4 to 6 inches long. Very ornamental and desirable, and a veritable gem for the garden.

Either of the above, strong plants, prepaid, $25 \mathrm{cts}$. each; larger plants, purchaser paying transportation, 25c. and 50c. each.

\section{Butneria . The Carolina Allspice and Sweet Shrub}

Aromatic shrubs with deliciously fragrant flowers and handsome foliage, everywhere admired and prized for their many ster-

ling qualities. In hardiness and adaptability to various conditions of soil and climate, they have been proved over and over again, always giving satisfaction and reason for Berberis aquifolium (see page 9) their great, yet growing, popularity.

Butneria fertilis (Calycanthus lavigatus and glaucus). CAROLINA AllsPicE. SIVEET SHRUB. A vigorous free-flowering shrub with upright, rigid branches. Flowers chocolate-colored, very fragrant, produced in late spring and early summer. Grows 4 to 6 feet tall.

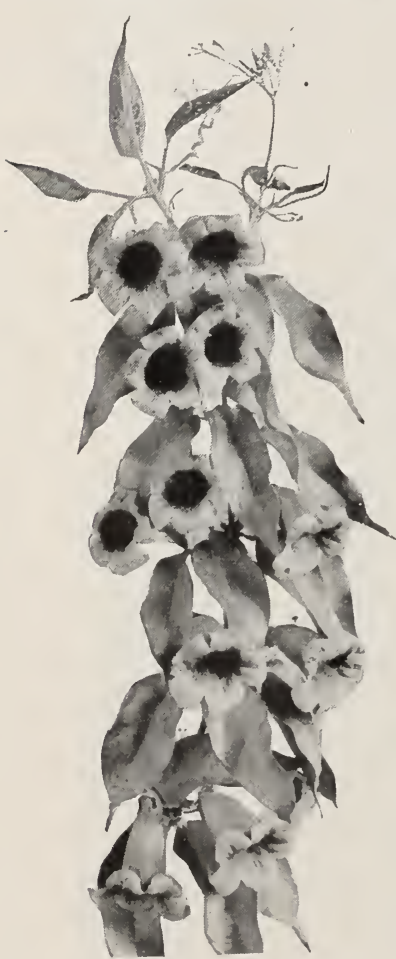

Bignonia crucigera (see page 9) The perfume of the fully developed blossoms is incomparably sweet and delightful.

B. florida (Calycanthus floridus). STRAWBERRY SHRUB. A desirable and very ornamental shrub, widely cultivated for its large fragrant blossoms. Flowers reddish brown, profusely borne in late spring and early summer, exhaling a fragrance so subtle and seductive that the atmosphere about them seems redolent of Oriental incense. Attains a height of 4 to 6 feet.

Either of the above, strong plants, prepaid, 15 cts. each ; larger plants, purchaser paying transportation, 15 cts. and $25 \mathrm{cts}$. each.

\section{Calluna}

Calluna vulgaris. Scotch HeAther. The famous heather of literature-the admiration of all who know its subtle charm. Few realize how easy it is to cultivate this chaste and dainty flower, yet it thrives in almost any well-drained soil and is hardy even in New England. The blossoms appear in great profusion along the slender cedar-like branches, and light with striking

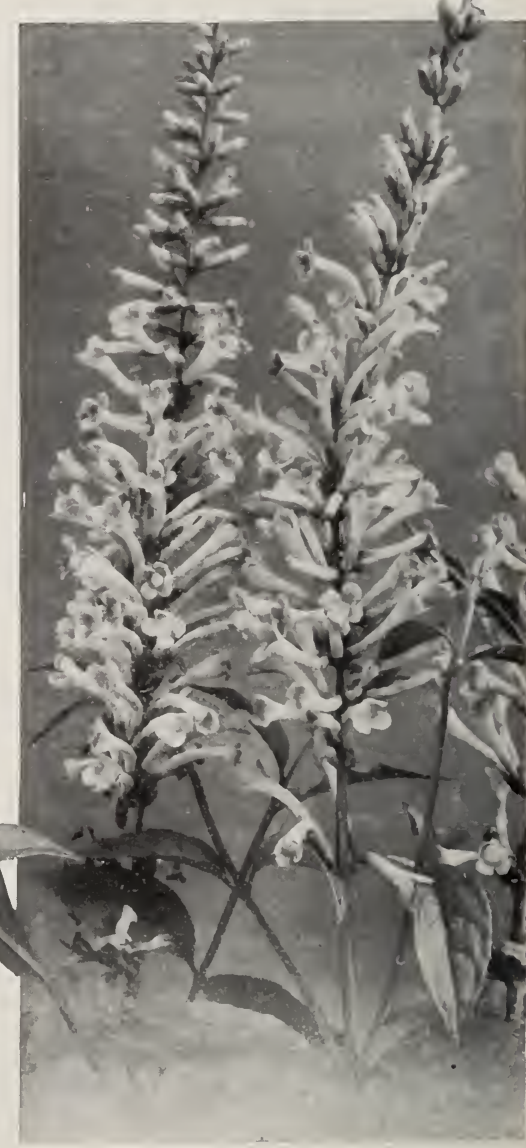

Buddleia lindleyana contrast the greenness of its low and com-

pact crown. A gem for any garden. Strong plants, prepaid, $25 \mathrm{cts}$. each; larger sizes, purchaser paying transportation, $25 \mathrm{cts}$. and $50 \mathrm{cts}$. each.

When I first read the tempting array of ferns in rour Catalogue I hesitated to order them because of the distance and the risk of shipment. But when the ferns came the other day I realized that you had successfully solved the problem of a practical shipment of your yoods. I have never had nursery material reach me in such excellent condition. Thank you and let me congratulate your shipping department. EDIVARD BoK, The Ladies Home Journal, Phila., Pa., April $27,1908$. 


\section{BILTMORE, N.C. TO NO}

\section{Camellia}

Camellia japonica. Camellia. The renowned Camellia, the pride of many gardens of the Southern States and California, and once so frequently used as a pot plant in the North, seems again to be awakening public favor by its meritorious and potent beauty. The handsome wax-like flowers, fashioned in such delicacy and symmetry of outline, are unsurpassed in form and substance, and lange in colors from purest white to pink, red and particolored forms. The double-flowering types are usually preferred. The lustrous deep green foliage is quite evergreen, and always attractive. Thrifty plants, prepaid, $75 \mathrm{cts}$. each: stronger plants, purchaser paying transportation, 75 cts., $\$ \mathrm{I}$ and $\$ \mathrm{I} .50$ each.

\section{Caragana . The Pea Shrubs}

The bright and cheery aspect of these hardy, floriferous shrubs is like sunshine in its influence, so cordial is the greeting The showy yellow blossoms, bending perchance with the weight of gaudy bumblebees, appear in great numbers in spring, and give a warmth and richness both pleasing and inspiring. They thrive in almost any well-drained soil.

Caragana arborescens. Siberian PEA SHRub. A large shrub with bright green feathery foliage, attaining a height of Io to I2 feet. Flowers yellow, produced in numerous small clusters in late spring.

C. chamlagu. Mongolian Pea Shrub. A small shrub, usually 3 to 4 feet high, with spiny branches. Flowers large

\section{and very showy, yellow with an orange shade,
opening in April and May;
very handsome. A rare
and beantiful plant.
Either of the above,
strong plants, prepaid, 25
cts. each ; larger sizes,
purchaser paying trans-
portation, 25 cts. and 50
cts. each.}

Caryopteris mastacan. thus. BLUE SPIREA. CHINESE BEARDWORT. A delightful and extremely free-flowering shrub, usually growing 3 to 4 feet tall. The lavender-blue flowers, which are abundantly pro-

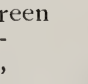 \\ ,
}

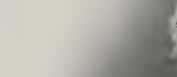

duced from summer until autumn, are of a rare and beautiful color seldom found among our garden subjects. Not quite hardy in the colder sections, where it frequently behaves as a herbaceous plant. Requires a well-drained soil and sunny situation. Thrifty plants, prepaid, 15 cts. each; larger sizes, purchaser paying transportation, I5 cts. and 25 cts. each.

\section{Castanea}

Castanea dentata. American Chestnut. A noble species, and in addition to its grandeur as a shade and nut tree, one of the most beautiful and imposing of summer-flowering subjects. The numerous clustered spikes of ecru appear at the tips of the branches, contrasting boldly and most effectively against the rich green of the clean, handsome foliage. Very hardy and vigorous, but demanding a well-drained soil with sunny exposure. Thrifty young plants, prepaid, 25 cts. each; larger trees, purchaser paying transportation, 25 cts. and 50 cts. each.

\section{Catalpa - The Catalpa Trees}

There are few trees, indeed, which present a more remarkablc floral display in summer than the Catalpas. They are exceptionally quick-growing, the spreading branches densely clothed with very broad leaves, which afford a cool, deep shade, and profusely bear long, upright panicles supporting numbers of large white flowers, beautifully spotted with purple and yellow. The slender, pendent seed-pods, Io to 18 inches long, hang all winter, and are both unique and attractive. 


\section{QF THLTMORE NURSERY W. W}

\section{Catalpa, continued}

Catalpa bignonioides. CATALPA. INDIAN BEAN. The flower-trusses of this species are very large and full, really gorgeous in effect, so strongly are they contrasted against the bright green and luxuriant foliage. Splendid as a specimen tree for the lawn.

C. speciosa. WESTERN CATALPA. The hardier of the two kinds and especially recommended for the colder sections. Extensively planted in the Middle and Western states as a timber tree. The individual flowers are two inches or more broad, borne in large loose trusses.

Either of the above, thrifty young plants, prepaid, 25 cts. each; large trees, purchaser paying transportation, $25 \mathrm{cts}$. and $50 \mathrm{cts}$. each.

\section{Ceanothus}

Ceanothus Americanus. New Jersey TEA. RED Root The great profusion of delicate foam-like flowers whirh enliven the leafy sprays of this extremely hardy little shrub has won many admirers. Indeed it would be difficult to find more delicate beauty than that typified by the dense clusters of white flowers which character ize the midsummer aspect of the Red Root. Splendid for rock-gardens and sunny borders. Strong plants. prepaid, 25 cts. each; larger sizes, purchaser paying transportation. $25 \mathrm{cts}$. and $35 \mathrm{cts}$. each.

\section{Cephalanthus}

Cephalanthus occidentalis. The Button Bush. We are frequently asked to recommend an attractive flowering shrub to occupy a position in damp soil, or for water-side planting. The Button Bush is ideal. Its hardiness and vigor, ample glossy foliage and creamy white flowers disposed in curious dense round heads, like the "buttons" of the Plane Tree, are foremost among the good qualities presented. The fragrant blossoms appear in midsummer, affording a unique and most attractive display. Strong plants, prepaid, 25C each; larger sizes, purchaser paying transportation, $25 \mathrm{cts}$. and $35 \mathrm{cts}$. each.

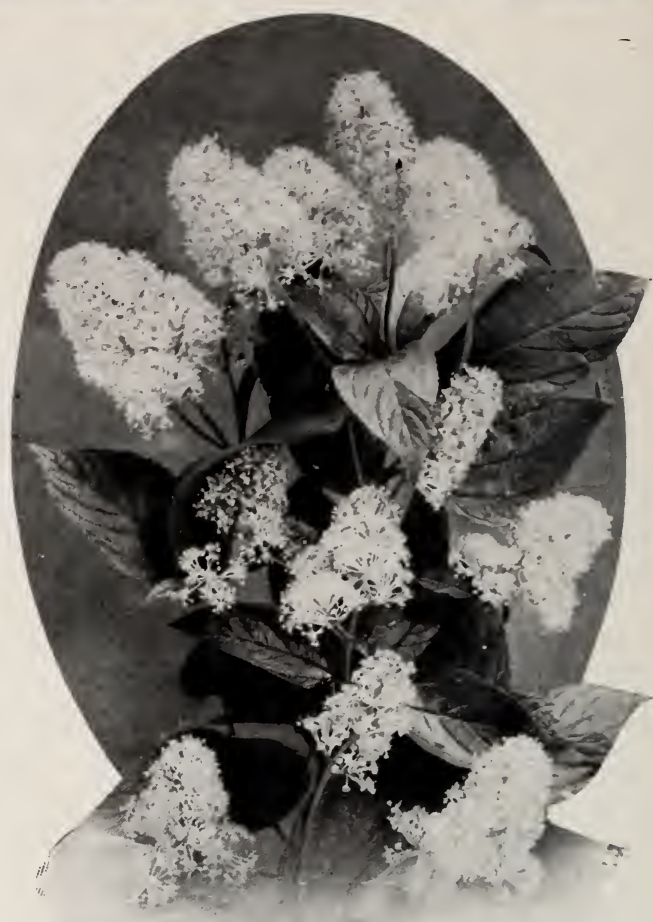

Ceanothus americana

The stock arrived safely and in good condition although they were nearly three weeks on the way. H. S. PEART, Director, Horticultural Exp. Sta., Jordan Harbor, Ont., 5-2-08.

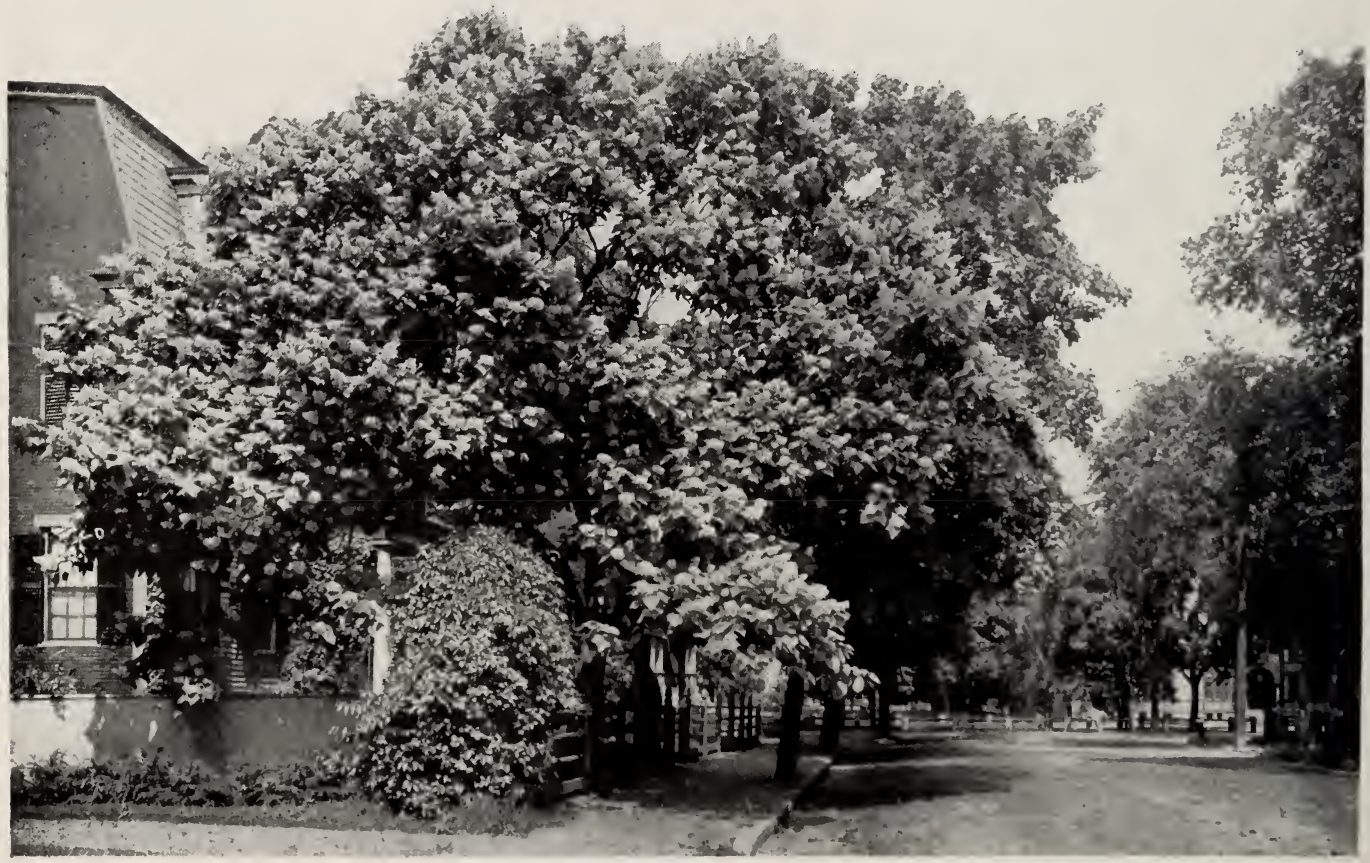

Catalpa speciosa in bloom 


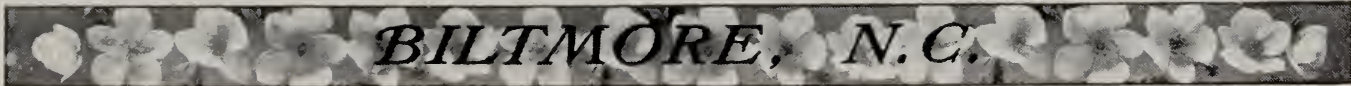

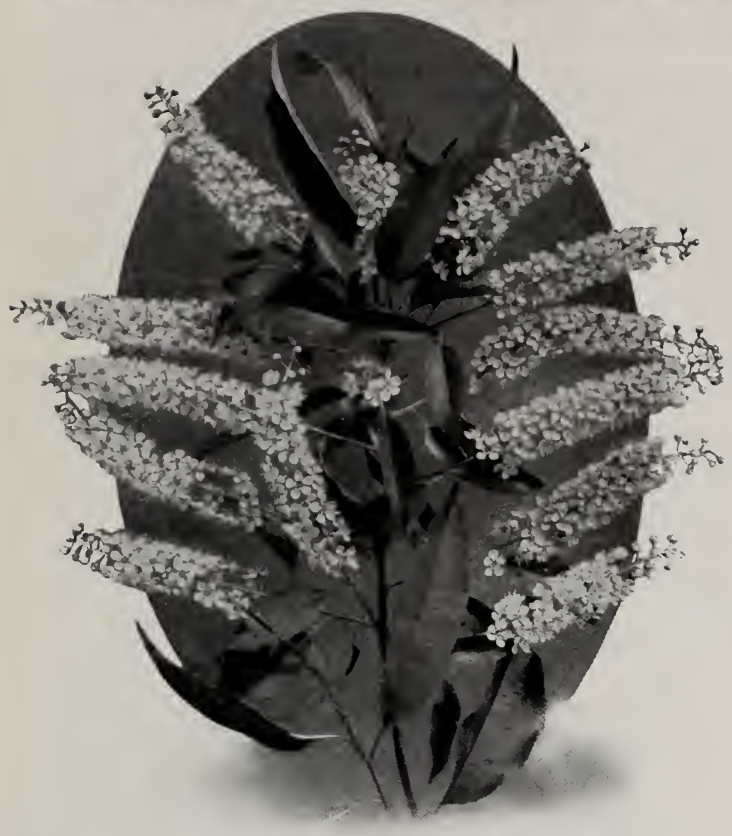

Cerasus serotina

\section{Cerasus - The Cherry Trees}

Do you enjoy the mystic, fairy-like beauty of blossoming Cherry trees? and have you seen the splendor of the enchanting forms which grace the Flowery Kingdom of the Orient? All this beauty may be yours each recurring spring, for they are of easy culture and possess great hardiness. The following are classed among the best:

Cerasus avium flore pleno. EUROPEAN DOUBLE-FLOWERING CHERRY. A charming garden tree of bright and cheerful aspect, literally covered with double white flowers in early spring. More lasting than single-flowered forms, consequently of great service as cutflowers.

C. hortensis. JAPANEse Flowering CherRy. The Famous Flowering Cherry Tree of Japan, so beautifully portrayed in many Japanese scenes. The flowers are very large, pink or blush, and open just as the leaves begin to expand. The single forms have a distinct and airy charm not outclassed by the double flowers, and in our estimation both should be in every garden. We can supply either single- or double-flowered forms, your choice of varieties, strong plants, prepaid, $50 \mathrm{cts}$. each ; larger sizes, purchaser paying transportation, $50 \mathrm{cts}$., $75 \mathrm{cts}$. and $\$ \mathrm{i}$ each.

C. padus. BIRD CherRy. A shrub or small tree bearing dense drooping racemes of white flowers in late spring. Besides its ornamental qualities, the profuse red or purple-black fruits are a great attraction to birds, which eagerly feed upon them. Very showy. Vigorous young plants, prepaid, $50 \mathrm{cts}$. each; larger sizes, purchaser paying transportation, $50 \mathrm{cts}$., $75 \mathrm{cts}$. and $\$$ I each.

C. pendula. JAPANESE WEEPING, or ROSE-BUD CHERRY. One of the handsomest and perhaps the most picturesque of early-flowering trees. The graceful drooping branches are thickly covered with dainty pink blossoms which open just as the leaves begin to unfold in spring. A vision of its loveliness is something never to be forgotten-so enchanting, so subtle is its charm. Thrifty young plants, prepaid, $75 \mathrm{cts}$.
Cerasus pendula, continued

each; larger trees, purchaser paying transportation, 75 cts., $\$ 1.50$ and $\$ 2$ each.

C. pennsylvanica. Wild Red Cherry. A shapely and extremely rapid-growing tree eminently suitable for the lawn. The early-appearing white flowers, so lavishly produced, cover the branches like a mantle of snow.

C. serotina. WILD BLACK CHERRY. A graceful tree and the latest of the Cherries to blossom. The white flowers appear in late spring, disposed in numerous long many-flowered racemes. A splendid subject for the lawn, and as an attraction to birds the fruits of this species seem unsurpassed, continuing to ripen over a period of several weeks.

Except where noted, any of the above Cherries, thrifty young plants, prepaid, 25 cts. each; larger sizes, purchaser paying transportation, 25c., 50c. and 75c. each.

SPECIAL OFFER. A collection of six Cherries, no two alike our selection of varieties, thrifty young plants, prepaid, $\$ 2$; larger sizes, purchaser paying transportation, $\$ 2$ and $\$ 3$.

\section{Cercis - The Judas Tree}

These beautiful hardy trees are among the showiest of ornamentals, being literally covered with handsome rose-pink flowers in early spring, almost concealing the branches and opening before the leaves appear. The flower-laden twigs are ideal for cutting and are remarkably durable when placed in vases containing water. Very highly recommended.

Cercis canadensis. Red Bud. Judas Tree. A small tree with spreading branches, fast growing and wonderfully floriferous. Decidedly one of the best of flowering trees and worthy of your consideration. Thrifty young plants, prepaid, 25 cts. each ; larger sizes, purchaser paying transportation, $25 \mathrm{cts}$. and $50 \mathrm{cts}$. each.

C. chinensis ( $C$. japonica). ORIEntal Judas Tree. A grand large shrub, possessing all of the beauty of

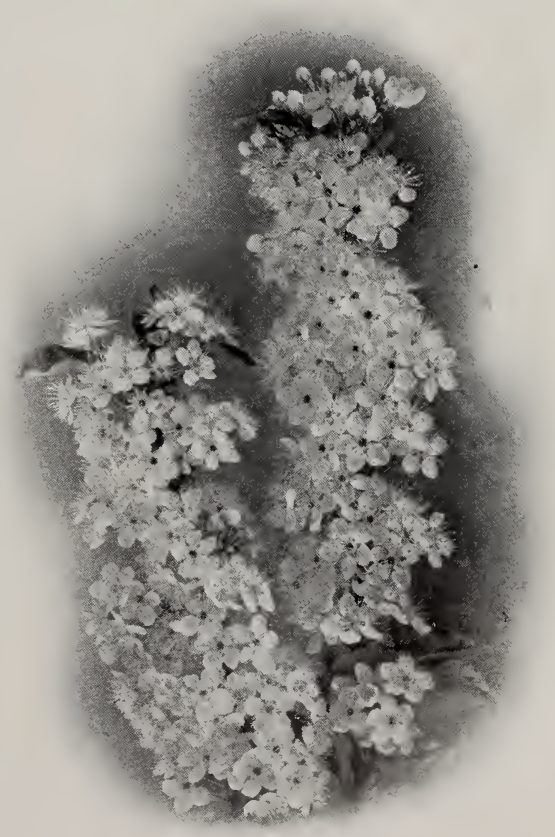

Cerasus pennsylvanica 


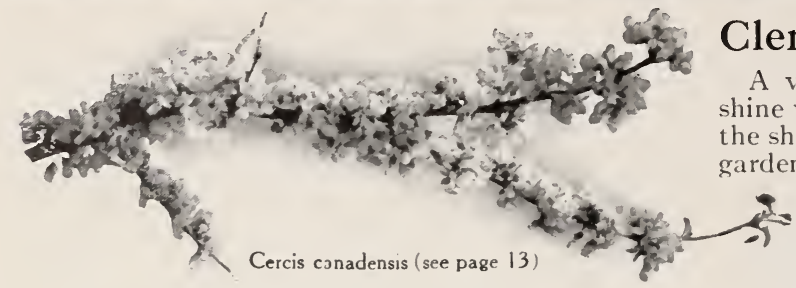

Cercis chinensis, continued

the arborescent species clescribed above, but of much less stature and requiring less space. The flowers are perhaps a little deeper in color tone, rosy-pink with a purple cast. Vigorous young plants, prepaid, $50 \mathrm{cts}$. each; larger sizes, purchaser paying transportation, 5o cts. and $75 \mathrm{cts}$. each.

\section{Chamaedaphne}

Chamaedaphne calyculata (Cassandra calyculata). LEATHERLEAF. A hardy low shrub with evergreen foliage; valuable for the extreme earliness of its pretty white flowers, which nod in leafy racemes with the first breath of spring. While it will flourish in the moist loam of the average garden, it is a splendid subject for wet or boggy land, such as a waterside planting. Thrifty young plants, prepaid, $25 \mathrm{cts}$. each; larger sizes, purchaser paying transportation, $25 \mathrm{cts}$. and 50 cts. each.

\section{Chimonanthus}

Chimonanthus fragrans. ORIExtal SweEt SHRUB. A unique free-flowering shrub, producing in earliest spring a wealth of exquisitely fragrant blossoms which expand before the leaves ap pear. The yellow flowers, often with the inner sepals tinged with purplish brown, deck the branches with a strange but subtle beauty, and cast their perfume everywhere. A splendid plant, especially for Southern gardens, for it is not trustworthy north of Washington and Memphis. Strong young plants, prepaid, $25 \mathrm{cts}$. each; larger sizes, purchaser paying transportation, 25 cts. and 50 cts. each.

\section{Chionanthus}

Chionanthus virginica. White Frixge. The loose drooping panicles of white flowers-so feathery and light-which grace the mid-spring appearance of the Fringe Tree, are borne in great profusion, and lend an airy softness and charm that is both fairy-like and beautiful. W'itl a background of evergreens or dark-leaved trees the showy effect is much intensified, resulting in many exclamations of pleasure and delight. Relatively hardy and extremely ornamental. Strong plants, prepaid, 5octs. each; larger sizes, purchaser paying transportation, $50 \mathrm{cts}$. and 75 cts, each.

\section{Cladrastis}

Cladrastis lutea (IVir-rilia lutea). YELLowwoOD. As a specimen tree for the lawn, the Yellow-wood, with its divided trunk and numerous wide-spreading, somewhat pendulous branches and symmetrical dome-like liead, is both beautiful and renowned. The loose drooping panicles of white flowers appear in early summer, adding a mystical and subtle charm. The bright green compound leaves change in autumn to various shades of gold. Thrifty young plants, prepaid, $25 \mathrm{cts}$. each; larger sizes, purchaser paying transportation, $25 \mathrm{cts}$, , $50 \mathrm{cts}$. and $\$ 1$ each.

\section{Clematis - The Clematis Vines}

A vine-clad bower, deflecting the summer sunshine with feathery foliage and radiant flowers from the shadowy coolness of its quiet retreat, is a joyous garden accessory. And the glorious Clematis vines,

- in company with climbing roses, or other climbers of the lesser rampant type, or even without the support of others, are ideal subjects to attain superb results. They are also splendid and well adapted for training on porches and trellises, where the graceful stems weave curtains of verdure massed with flowers.

Clematis hybrida. LARGE-FLOWERING Clematis, Magnificent, indeed, with glorious starry blossoms renowned for size and brilliant splendor. Like scepters of a throne, the flowers stand out in bold relief on long stout stems above the feathery foliage, and make the summer aspect one of radiant beauty. This type of Clematis requires a depth of good rich earth, and as they are very susceptible to injury by drought or standing water, it is essential to secure moist, yet porous and well-drained situations. There are many varieties in cultivation, among which the following are extra-good: Henryi, creamy white; a robust free-flowering variety. Jackmanni, velvety purple, with a ribled bar in the middle of each sepal: very floriferous and the best and most popular variety: Mme. Edouard Andre, violet-red, profuse and rigorous. Your choice of forms. Strong plants, prepaid, $40 \mathrm{cts}$. each; larger sizes, purchaser paying transportation, $40 \mathrm{cts}$. and 50 cts. each.

C. paniculata. JAPANESE Clemitis. All billowy with fragrant foamy masses of flowers toward the end of summer, so profusely borne that the upper portions of

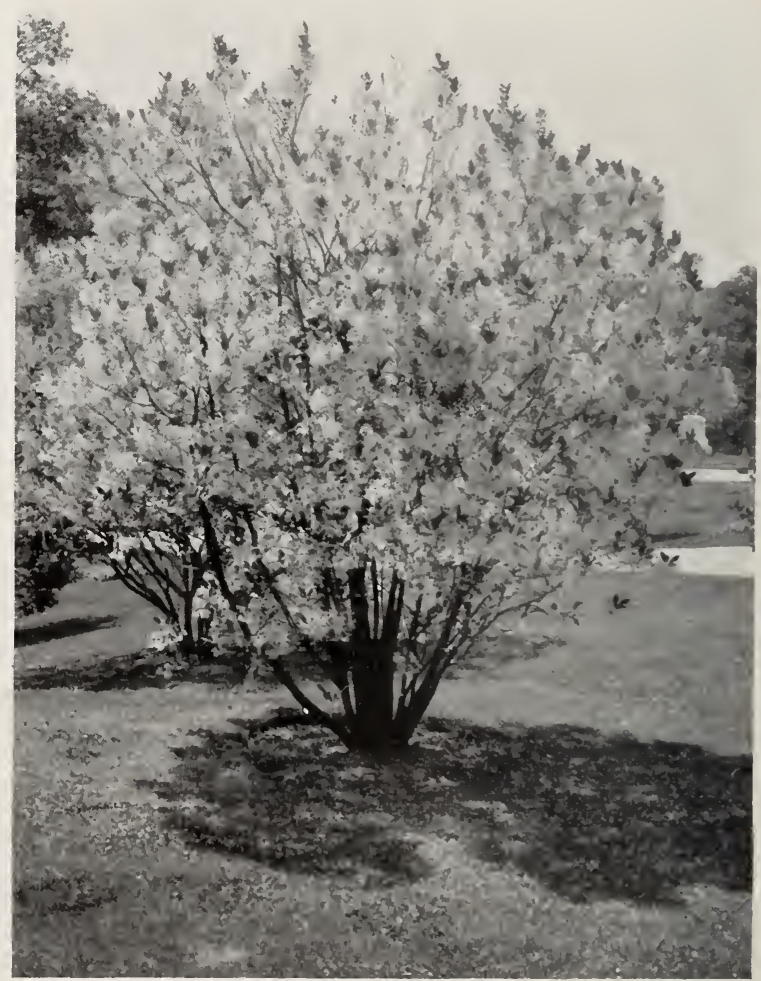

Chionanthus virgin ca 


\section{BILTMORE, N.C. T से?}

Clematis paniculata, continued

the vine are literally robed in dazzling white, the glorious Japanese Clematis presents an appearance both gorgeous and enlirening. The autumn splendor of the feathery seeds prolongs the season of beauty and display. W"ith only here and there a parallel, this splendid vine has won a popularity unique in horticultural annals-a distinction gained alone by sterling worth and merit. You should have it. Strong plants, prepaid, 25 cts. each; larger sizes, purchaser paying transportation, 25 cts. and 35 cts. each.

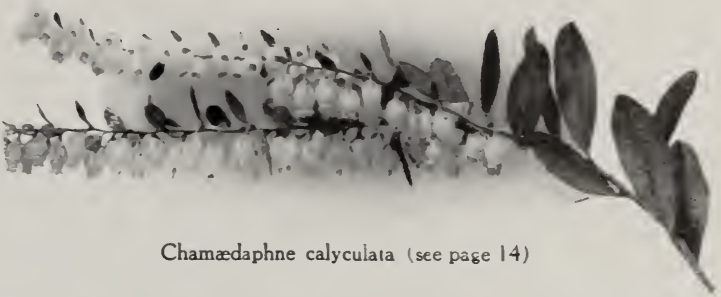

\section{Clethra . The Sweet Pepper Bushes, or White Alders}

Justly classed among the most desirable and ornamental of garden shrubs, the dainty Clethras, noted both for hardiness and the beauty of their profuse and fragrant blossoms, find few rivals that excel in summer flowers. They are splendid garden subjects, sure to grow and sure to please. Clethra acuminata. Mourtaix PEPper Besh. A tall
shrub with dark green, long-pointed leaves. Flowers - creamy white, fragrant, produced in slender nodding racemes. A show plant, but quite rare in cultivation. Thrifty young plants, prepaid, 25 cts. each; larger sizes, purchaser paying transportation, $25 \mathrm{c}$., 35c. and $50 \mathrm{c}$. each.

C. alnifolia. SweEt PePper Bush. A sturdy, compact shrub, grand in all its attributes, and worthy of a prominent place in any garden. Flowers creams white, with wonderful fragrance, produced in numerous upright spikes of slender outline. Just what you want and will appreciate. Vigorous young plants, prepaid, $1_{5} \mathrm{cts}$. each: larger sizes, purchaser paying transportation, $15 \mathrm{c} ., 25 \mathrm{c}$. and 5oc. each.

\section{Colutea}

Colutea arborescens. BLADDER SENrA. Rapid-growing and floriferous, the Bladder Semna presents a stalwart and unique appearance when loaded with its sunny yellow flowers and curious inflated seed-pods, which, like the blossoms, are often tinged with red and brown. Sure to prompt interrogation. Relatively hardy, but appreciates protection from cold and piercing winds. Strong plants, prepaid, $25 \mathrm{cts}$. each; larger sizes, purchaser paying transportation, 25 cts. and $50 \mathrm{cts}$. each.

\section{Cornus . The Dogwoods}

Prominent among the hardiest and showiest of the flowering plants are the glorious Dogwoods, with their radiant crowns of beauty, which lend so majestically to the brightness and enchantment of spring. The wonderful dura tion of the floral display, the grace of outline, green of foliage-especially when considered in connection with the rich and lavish tints of autumn and the glowing red or scarlet of the long-persistent berries-present a list of attributes that challenges a peer.

Cornus florida. White-Flowerisg Dogwood. Some of the most enchanting results in ornamental planting are attained by the use of this beautiful tree. Flowers expanding in early spring, the large white petal like bracts often diffused with pink. Indispensable for lawn or landscape. Thrifty young plants, prepaid, $25 \mathrm{cts}$. each; larger sizes, purchaser paying transportation, $25 \mathrm{cts}$., $50 \mathrm{cts}$. and $75 \mathrm{cts}$. each.

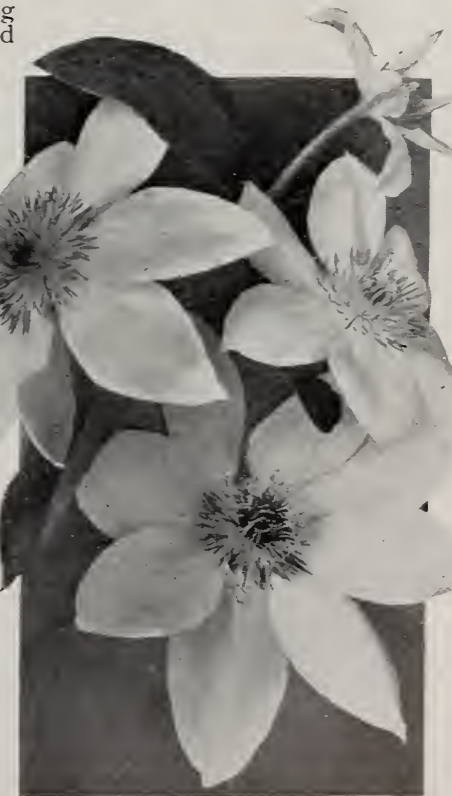

Clematis Henryi (see page 14) 


\section{BILTMORE NURSERY W WE}

\section{Cornus, continued}

Cornus florida pendula. WEEPING DogwooD. This graceful form has the same beautiful flowers and fruit as the type, but the branches are pendulous. Vigorous young plants, prepaid, \$I.50 each; larger sizes, purchaser paying transportation, $\$ 1.50$ and $\$ 2$ each.

C. florida rubra. REDFLOWERING DOGWOOD. A strikingly beautiful tree, and especially when planted in contrast with and as a companion for the whiteflowered or typical form. The floral bracts are of a pleasing bright pink color. Vigorous young plants, prepaid, \$I each; larger sizes, purchaser paying transportation, \$I and \$I.5O each.

\section{Corylus}

Corylus avellana. FILBERT, HAZEL. The long drooping catkins of the Hazel, expanding with the first breath of spring and draping the branches with streamers of brown and gold, are indeed graceful and attractive; their precocity and defiance of chilling winds making them all the more desirable. And few plants are more responsive in the vernal resurrection - the awakening into new lifethan this hardy, vigorous shrub. Vigorous young plants, prepaid, 25c. each ; larger sizes, purchaser paying transportation, $25 \mathrm{cts}$. and $50 \mathrm{cts}$. each.

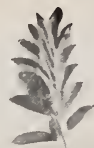

\section{Cratægus - The Hawthorns}

Many forms of these hardy and very ornamental small trees or shrubs have been described, but for all purposes of the garden or lawn the list following, and especially the double-
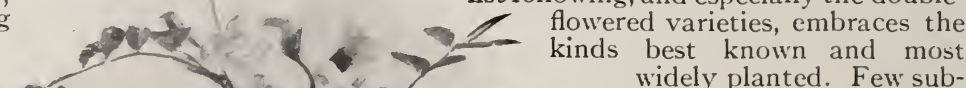
widely planter jects seemingly care so little about the kind of soil they grow in, and few are more lavish with their flowers. Very showy, both in flower and fruit, and effectively used as specimen objects on the lawn, or in combination with shrubs in the borders.

Crataegus cordata. IVASH INGTON THORN. Exceedingly floriferous; the dense clusters of blossoms appearing like a mantle of snow. Fruit scarlet, very lustrous, persisting until the following spring. The heart-shaped, dark shining green leaves fade in autumn with gorgeous tones of orange and scarlet. Assumes the proportions of a small tree.

C. crus-galli. CocksPUR THORN. A broad roundtopped shrub or small tree with very spiny branches. The large clusters of white flowers are very showy, and contrast strikingly with the shining green leaves. The dull red fruits hang from the

Colutea arborescens (see page 15) branches all winter

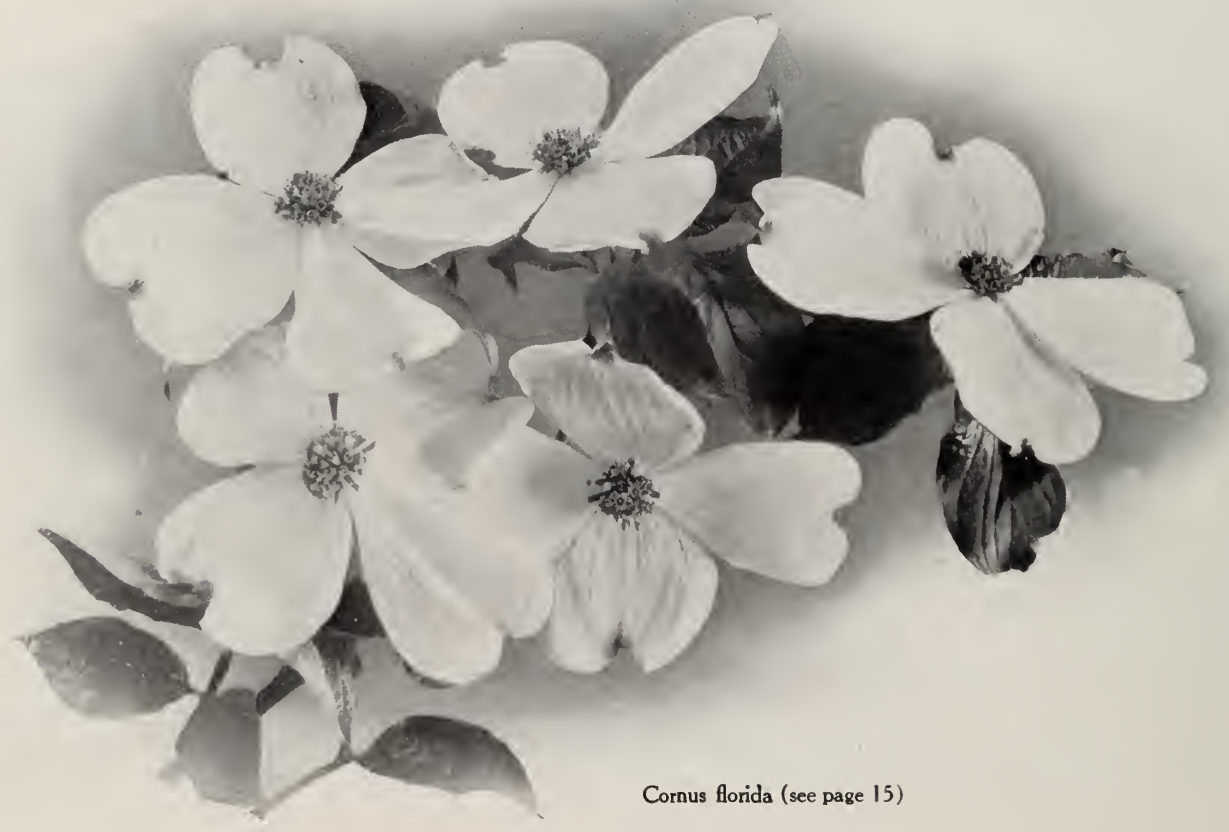




\section{BILTMORE, N.C. H. T.}

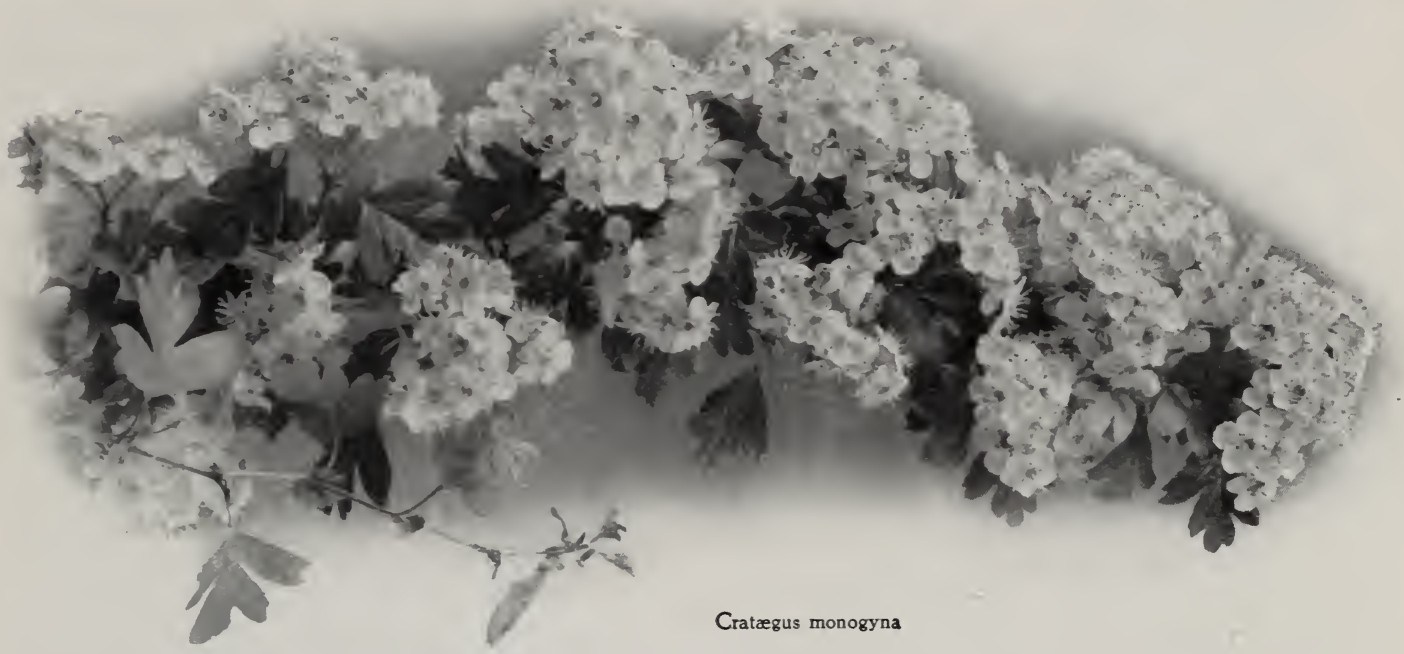

Cratægus, continued

Crataegus monogyna. ExGLish HAwTHORx. When covered with a great mass of snowy blossoms, or gay with its load of scarlet berries, the English Hawthorn is quite worthy the commendation so frequently associated with it by those who know its qualities. The profusion of flowers is truly remarkable, rendering it an extremely desirable subject for specimen plants or hedges.

Any of the above Hawthorns, strong plants, prepaid, 25 cts. each; larger sizes, purchaser paying transportation, $25 \mathrm{cts}$. and 50 cts each.

C. monogyna alba plena. DOUbLE White HAwthorx. An extremely handsome shrub or small tree with beautiful double white flowers. The bright glossy green leaves add much to the attractiveness, rendering the sprays most valuable for cut-flowers and floral decorations. Highly recommended.

C. monogyna pauli. DOUble SCARLET THORX:. Similar to the last, but the flowers are bright scarlet, large, full and very double. A splendid companion tree, and in our estimation the most showy of the double-flowering Thorns.

C. monogyna punicea. SIxgle RED HAwthorx. A vigorous grower, forming a beautiful small tree. Flowers single, deep red.

Any of the above Hawthorns, vigorous young plants, prepaid, 50 cts. each; larger sizes, purchaser paying transportation, 50c. and 75c. ea.

\section{Cydonia}

Cydonia japonica (Pyrus japonica). JAPANESE, Or FLOWERING QUINCE. The glory of this old-fashioned, timehonored shrub, radiant with its garland-decked branches in early spring, is not dimmed by the competition of fairest rivals-so exclusive is its type of beauty. With extreme hardiness and adaptability foremost in its list of attributes, no better plant could be selected for border or garden planting, or for informal

\section{Cydonia japonica, continued}

or clipped hedges. The form with bright scarlet flowers is the most popular, but we can supply for contrast and as companion plants, varieties with crimson, white, and rose-tinted blossoms. Vigorous young plants, prepaid, I5 cts. each; larger sizes, purchaser paying transportation, I5 cts., 25 cts. and $35 \mathrm{cts}$. each.

\section{Cytisus}

Cytisus scoparius (Genista scoparia). Scotch BRoOM. A strange and interesting shrub with long and slender green-barked branches. It thrives in almost an well-drained soil, preferring sumn situations. The bright yellow flowers which bend the branches by their weight and great profusion, illuminate, like sunshine, the verdure of the almost leafless shoots which bear them. Try this pretty plant: it is unique. Strong plants, prepaid, $25 \mathrm{cts}$. each: larger sizes, purchaser paying transportation, $25 \mathrm{cts}$. and $50 \mathrm{cts}$. each.

\section{Daphne . The Garland Flowers}

The fragrance and the charm of dainty Daphne blossoms have won for them a name and fame throughout the land, and iustly, too, for their beauty is captivating.

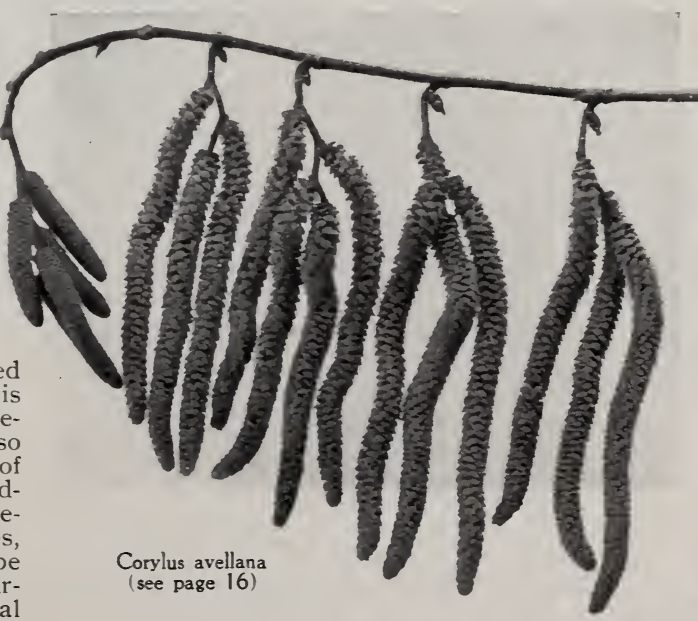
They are hardy; and thrive best in light, well-drained soils, either in full sun or partial shade. Every garden should possess them.

Daphne cneorum. GARI AND Flower. A dwarf shrub of trailing habit,'with dark green persistent foliage. Flowers pink, disposed in numerous compact clusters, delightfully fragrant. Really one of the daintiest of flowering shrubs, and deserving of the highest commendation. Vigorous roung plants. prepaid, 5o cts. each ; larger sizes, purchaser paying transportation, 50 cts. and Si each. 


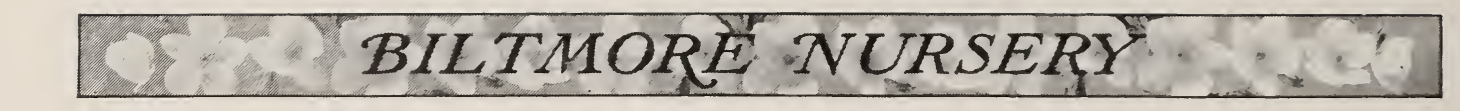

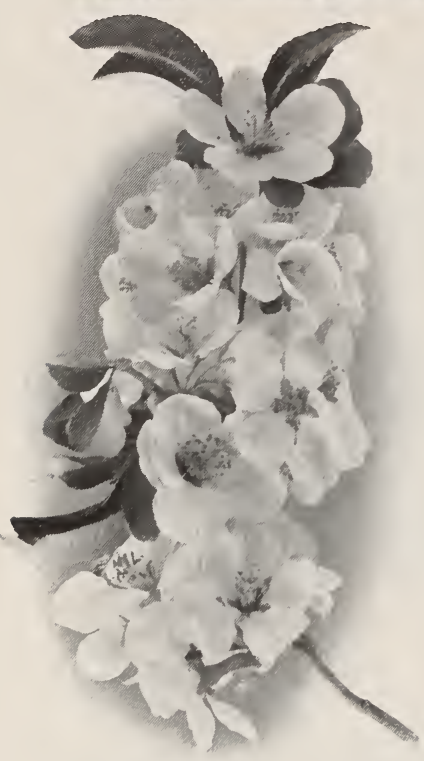

Cydonia japonica (see page 17)

\section{Daphne, continued}

Daphne genkwa. JAPANESE DAPHNE. A small deciduous shrub with slender branches, usually about 2 feet tall. The showy lilac flowers, which appearbefore the leaves unfold, are profuse and fragrant, and completely hide the twigs and stems. A rare and handsome plant. Thrifty roung plants, prepaid, \$I each; larger plants, purchaser paying transportation, \$I and \$I.5O each.

D. mezereum. Mezereon Daphne. A grand shrub, and fortunately, a robust hardy species, usually growing 3 to 4 feet tall. The fragrant lilac-purple flowers expand before the leaves appear, and are so profuscly borne that they almost conceal the naked branches. Should be in every garden. Vigorous young plants, prepaid, $25 \mathrm{cts}$. each ; larger sizes, purchaser paying transportation, $25 \mathrm{cts}$., $50 \mathrm{cts}$. and $75 \mathrm{cts}$. each.

\section{Decumaria}

Decumaria barbara. AMERICAN Clmining HydRANGea. With distinctiveness and rare beauty among its chiefest claims, this show y vine, clinging by aërial rootlets to the trunks of trees or mantling walls of masonry in garments of glossy green, affords a display of fluffy fragrant blossoms in white that is charming and delightful. This unique $\mathrm{climber}$ thrives best in moist, loamy soil in partial shade, and is hardy as far north as Washington and Memphis, but requires protection in colder climates. Strong plants, prepaid, 25 cts. each; larger sizes, purchaser paying transportation, $25 \mathrm{cts}$. and $50 \mathrm{cts}$. each.

\section{Dendrium}

Dendrium buxifolium (Leiophyllum buxifolium). SAND IyrtLe. A dainty, hardy little shrub, quite evergreen, adapting itself in striking conformation in the rock-garden. Flowers white or pinkish, borne in great profusion in spring. Very neat and attractive. Vigorous young plants, prepaid, $25 \mathrm{cts}$ : each ; larger sizes, purchaser paying transportation, 25 cts. and $50 \mathrm{cts}$. each.

\section{Deutzia - The Deutzias}

High praise and unstinted commendation per-

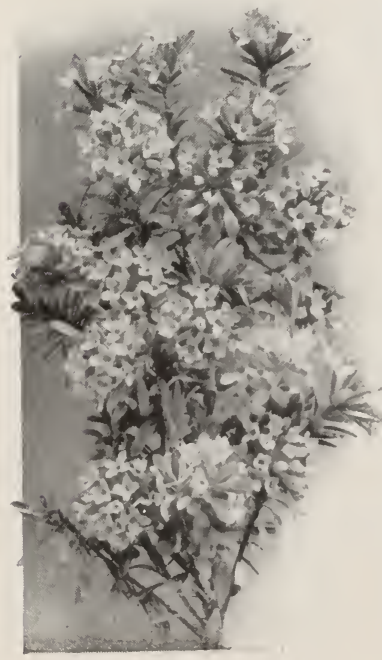

Daphne cneorum (sce page 17) vade every testimonial which we receive from those who have planted the charming Deutzias. Few shrubs are of such casy culture, and still fewer which give such universal satisfaction and such myriads of flowers. The

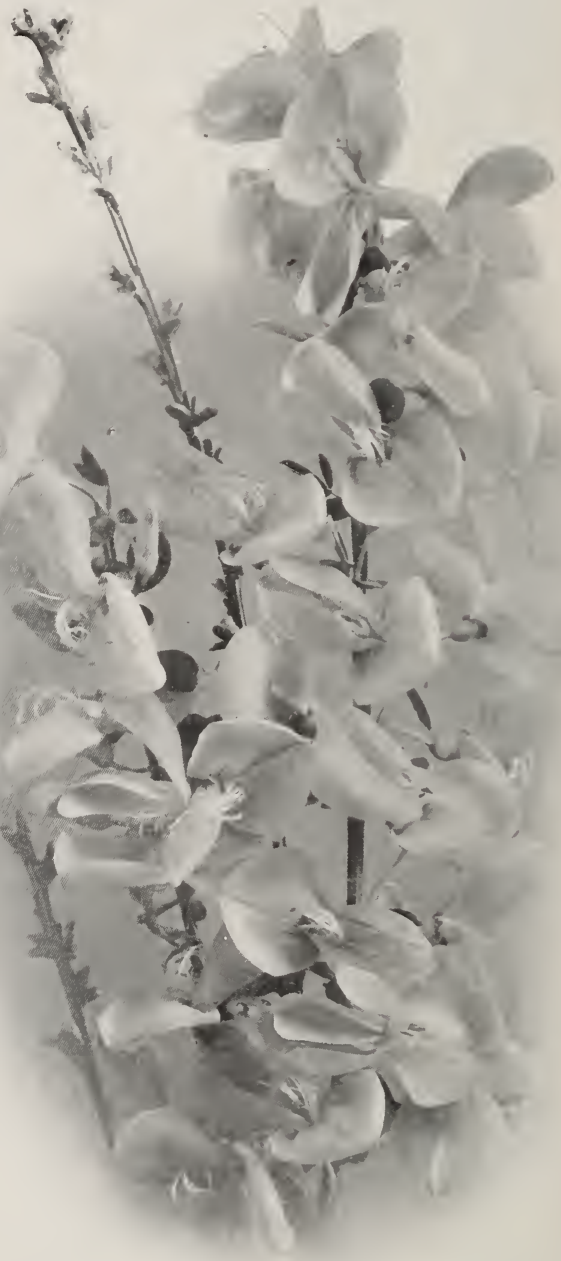

dazzling white or soft rosy pink of their pretty blossoms make possible many striking effects in garden or border plantations. They are really indispensable.

Deutzia crenata candidissima. Double White DeutziA. A tall shrub, usually 6 to 8 feet high, with numerous upright branches. Flowers very double, pure white, disposed in numerous dense clusters 2 to 4 inches long. Remarkably handsome and floriferous.

D. crenata flore roseo plena. DOUbLe PINK DEutziA. Similar to the preceding and a splendid companion plant, but with one or more of the outer row's of petals rosy pink. Very showy.

D. gracilis. SLeNDER Deutzi.. A small shrub, usually about 2 feet tall, with slender, often arching branches. Flowers single, pure dazzling white, borne in graceful nodding racemes. Simply grand. 


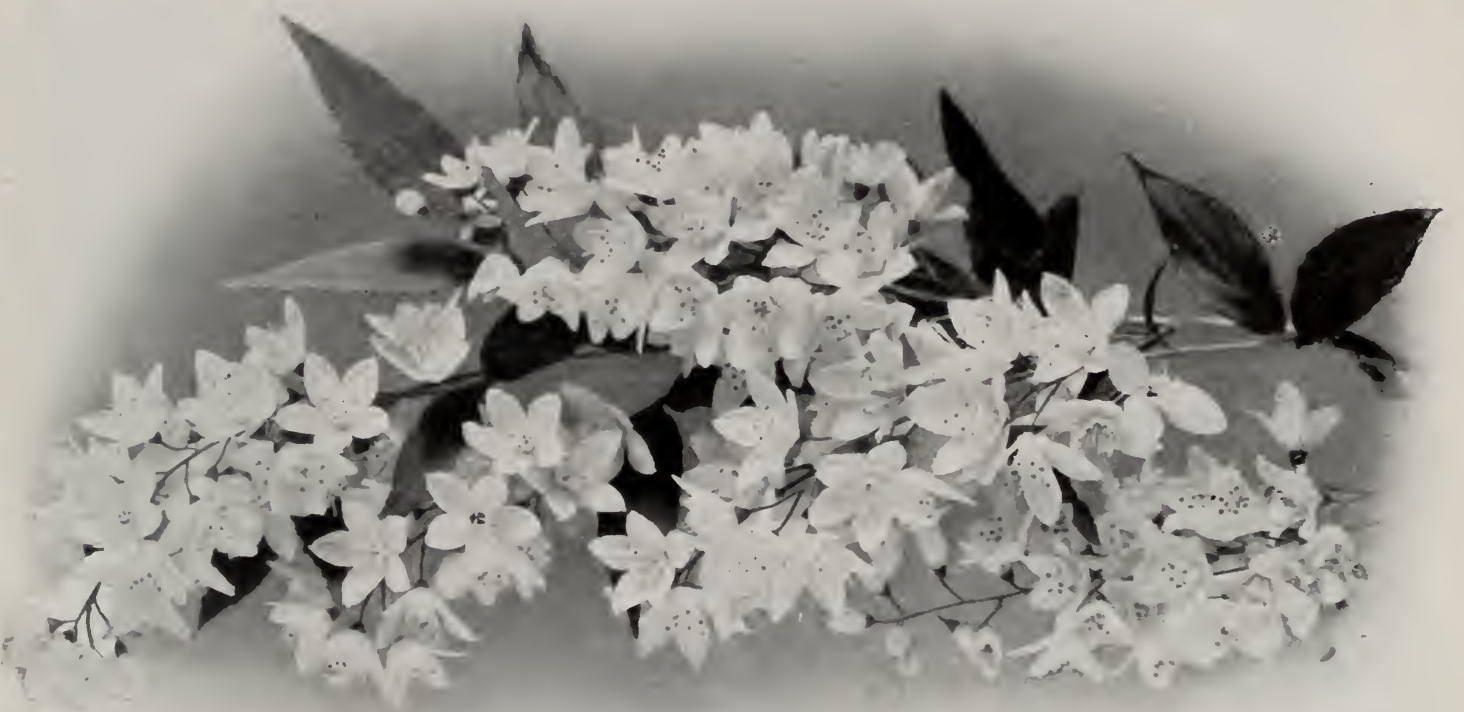

Deutzia gracilis (see page 18)

Deutzia, continued

Deutzia lemoinei. Lemoixe's Hybrid DeutziA. A small shrub with spreading branches, usually about 3 feet tall. The single pure white blossoms are borne in large, often compound clusters, and clothe the branches like a mantle of snow. A gem.

D. scabra. Rough-LeAved Deutzia. A tall shrub, usually 6 to 8 feet high, with the leaves roughened like sand-paper. Flowers single, pure white, profuse and very showy. Charming.

Any of the Deutzias, strong plants, prepaid, $15 \mathrm{cts}$. each; larger sizes, purchaser paying transportation, 15 cts., 25 cts. and 35 cts. each.

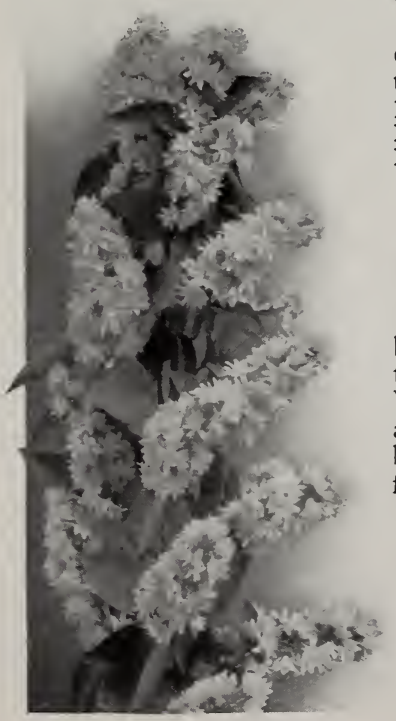

Deutzia crenata flore roseo plena (p. 18)
SPECIAL OFFER. One each of the above, thrifty young plants, prepaid, 60 cts. ; larger sizes, purchaser paying transportation, 60 cts. and $\$ 1$.

\section{Diervilla The Weigelias}

The masses of showy blossoms which deck the branches of the Weigelias in late spring and early summer are bewilderingly beautiful; and the profusion of the flowers and the luxuriance of their setting, make a picture never to be forgotten. All of the varieties are hardy and of easy cultivation. We can recommend but few
Diervilla, continued

other plants that will give such universal satisfaction and such admirable results.

Diervilla florida (Weigelia rosea). WVEIGELIA. A freeflowering and vigorous shrub, usually growing about 6 feet tall. The large and showy rose-colored flowers literally cover the spreading branches, which appear like garlands in their graceful outlines. A rery meritorious and desirable subject. A variety with pure white flowers, known as Candida, is a splendid companion plant. Your choice of colors.

D. hybrida. HrbRID WeIgeli. Similar in habit to the preceding, but affording an extreme variation in the color of the flowers. The variety Eva Rathke, with deep carmine-red flowers is

the best and most popular form

of these hybrids. A splendid floriferous shrub.

Any of the Weigelias, vigorous young plants, prepaid, 15 cts. each; larger sizes, purchaser paying transportation, $15 \mathrm{cts}$. 25 cts. and 35 cts. each.

SPECIAL OFFER. One each of the three superb Weigelias described above, thrifty plants, prepaid, 35 cts.; larger sizes, purchaser paying transportation, 35 cts., 55 cts. and 75 cts.

The trees you sent have all The trees you sent have all arrived and are very fine stock, apparently in excellent condition. We have been
fortunate in the weather and fortunate in the weather and conditions for planting and hope for good results. Very truly yours, S. A. MARTIN, pensburg, Pa., April 2t, zo08. 


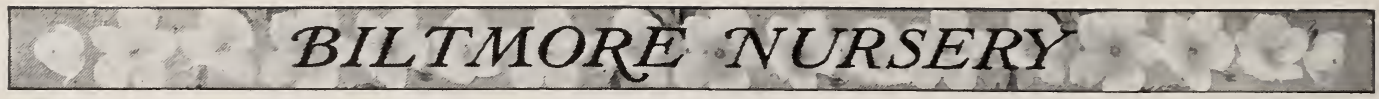

\section{Elæagnus - The Oleasters}

Hardy shrubs, with handsome foliage and showy flowers and fruits. The young branches and leaves are covered with silvery or bronze-brown scales, which impart a singular luster and aspect. The two species here described, when planted side by side, one with silver coating, the other of bronze, present a novel and striking contrast that results in exclamations of wonder and delight.

Elaeagnus angustifolia ( $E$. hortensis). Russian Olive. A large shrub with silvery, often spiny branches. Flowers yellow within, silvery on the outside, very fragrant. Leaves silvery white beneath, deciduous. Berries yellow, coated with silvery scales. Vigorous young plants, prepaid, I5 cts. each; larger sizes, purchaser paying transportation, $15 \mathrm{cts}$. and $25 \mathrm{cts}$. each.

E. longipes. THE "Gouml" OF JAPAN. A large slirub with bronze-brown

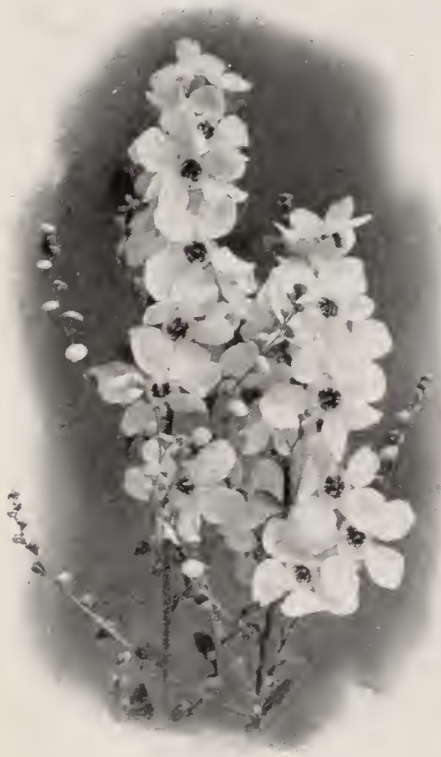
twigs and branches. Flowers yellowish white, fragrant, more or less covered with bronzebrown scales, as also are the lower surfaces of the dark green transient leaves. Berries red, drooping on long and slender pedicels, often used in making delicious jellies and jams. Vigorous young plants, prepaid, $25 \mathrm{cts}$. each; larger sizes, purchaser paying transportation, $25 \mathrm{cts}$. and $50 \mathrm{cts}$. each.

\section{Erica . The Heaths}

Charming little shrubs, densely clothed with small, evergreen, needle-like leaves, thriving in sheltered situations, even in the North. They are very showy plants and are unexcelled tor planting in the rock-garden. The species described are the hardiest, and succeed best in porous, fertile soils.

Erica carnea. MOOR HEATH. A low, dainty shrub. Flowers bright rose, nodding, borne on short pedicels, opening in early spring.

E. stricta. CoRsican Heath. The largest of the forms here described, with erect and rigid branches. Flowers rosy purple, disposed in terminal clusters, opening in summer and early autumn. Very showy.

E. vagans, CORNISH HEath. A free-flowering little shrub with the leaves in whorls of fours and fives. Flowers purplish red, borne on one side of the branches and expanding in summer and early autumn. A gem.

Any of the Heaths, vigorous young plants, prepaid, 25 cts. each; stronger plants, purchaser paying transportation, $25 \mathrm{cts}$. and $50 \mathrm{c}$. each.

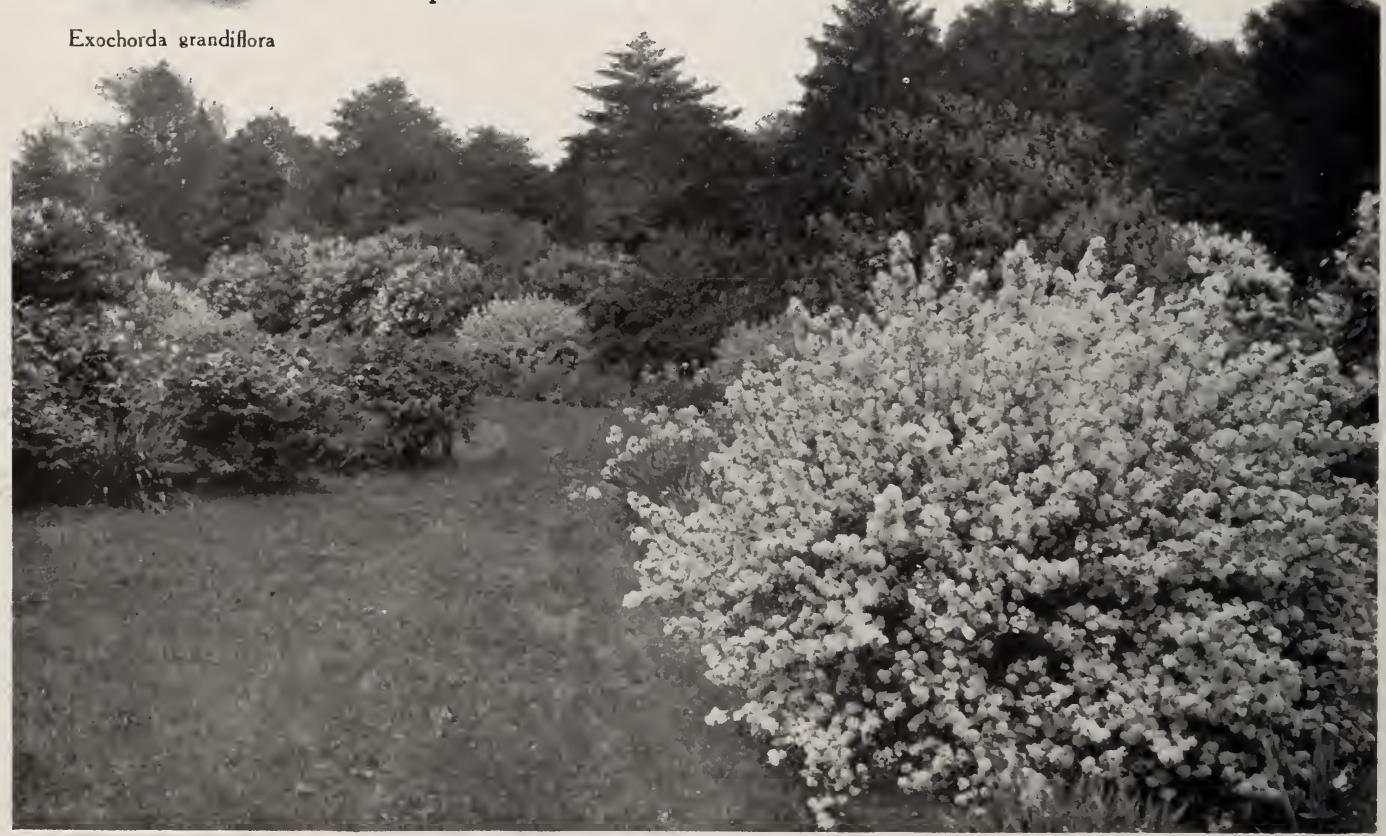

Deutzia lemoinei in full bloom (see page 19) 


\section{Exochorda}

Exochorda grandiflora. PEARL BUSH. This hardy free-flowering shrub is unquestionably one of the floral gems. The magnificence of its dazzling white blossoms, so distinct and exclusive in their outlines, is remarked by almost all who see its wonderful display in early spring. Usually grows from 8 to ro feet tall. Very highly recommended. Strong plants, prepaid, $25 \mathrm{cts}$. each; larger shrubs, purchaser paying transportation, $25 \mathrm{cts}$. and $50 \mathrm{cts}$. each.

\section{Forsythia - The Golden Bells}

Few, if any, of the spring-flowering hardy shrubs can surpass the splendor and brilliancy of the Forsythias. Both grace and beauty are combined in all their attributes and give them rank for any station in the shrub plantations. The brightness of their yellow blossoms, like sunshine in its noon-day glory, illuminates the densely flower-laden branches with rare and subtle floral treasures.

Forsythia suspensa. Drooping Golden Bell. A graceful shrub with $1 /$ long and slender drooping branches. Flowers in great profusion in early spring, golden yellow; very showy. Grows about 8 feet tall. One of the showiest shrubs in cultivation.

F. suspensa fortunei. FORTUNE's GOLdEN BELL. Similar to the preceding species, but of more vigorous upright habit. The arching branches are literally covered in early spring with golden-yellow blossoms with long and often twisted petals. A grand shrub.

F. viridissima. DARK GreEN FORsythia. A large shrub with erect green-barked branches. Flowers golden-yellow, with somewhat reflexed, often twisted petals. Decidedly one of the best and showiest of the Forsythias, but in the very coldest portions of the country perhaps not so hardy as the foregoing varieties.

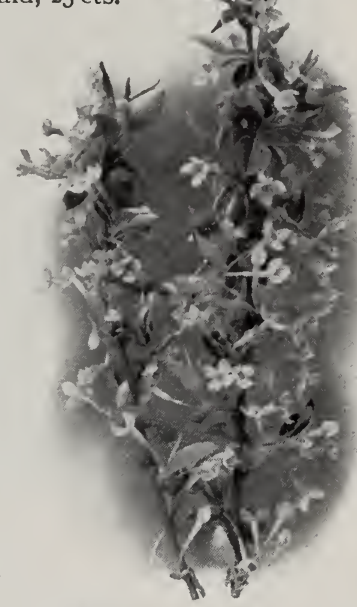

Elæagnus longipes (see p. 20)

Any of the Forsythias, strong plants, prepaid, 15 cts. each; larger shrubs, purchaser paying transportation, $15 \mathrm{cts}$., $25 \mathrm{cts}$. and $35 \mathrm{cts}$. each.

SPECIAL OFFER. One each of the glorious Forsythias, as above, strong plants, prepaid, $35 \mathrm{cts}$; l larger sizes, purchaser paying transportation, $35 \mathrm{cts}$., $55 \mathrm{cts}$. and $75 \mathrm{cts}$.

\section{Fothergilla - The Fothergillas}

Although rarely seen in gardens, the Fothergillas are extremely beautiful and showy, producing in early spring numerous heads or spikes of creamy white, fluffy blossoms from the tips of the shoots and branches. They are admirably adapted for planting in the foreground of shrub borders, and make most attractive and noteworthy subjects

Erica vagans (see p. 20) 


\section{Q. BILTMORE NURSERY}

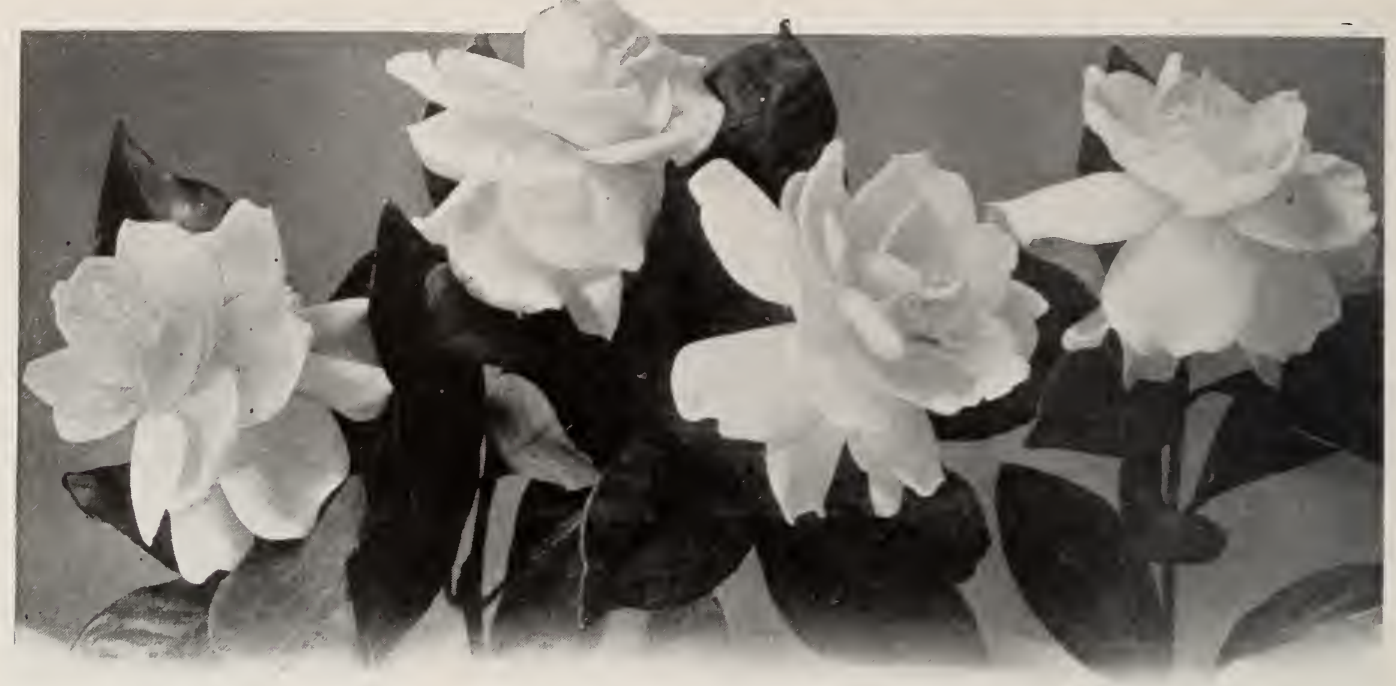

Gardenia jasminoides fortunei

Fothergilla, continued

Fothergilla carolina ( $F$. gardeni and alnifolia). DivarF FOTHERGilla. A low, much-branched shrub, usually attaining a height of about 2 feet. Flowers in dense terminal clusters, very soft and feathery. A dainty and charming plant.

F. major. LARGE Fothergilla. An upright, bushy shrub, eventually 4 to 5 feet high. The large and showy plume-like spikes of flowers are remarkably attractive. A beautiful and extremely rare plant.

Either of the Fothergillas, vigorous young plants, prepaid, 50 cts. each; larger sizes, purchaser paying transportation, $50 \mathrm{cts}$. and $75 \mathrm{cts}$. each.

\section{Fraxinus}

Fraxinus ornus. Flowering AsH. A remarkable small tree producing dense terminal panicles of fragrant white flowers in late spring or early summer. Very showy. Altogether too little known in our gardens, but sought after by the discriminating planter who wants something different, something unique and distinctive. Vigorous young plants, prepaid, 25 cts. each ; larger trees, purchaser paying transportation. 25c. and 5oc. ea.

\section{Gardenia}

\section{Cape Jasmines}

The popularity of these beautiful evergreen shrubs, which are so highly esteemed tor the purity and wonderful fragrance of their showy white blossoms, is again at floodtide. And they merit all of the enthusiasm that has been bestowed upon them. Hardy as far north as Tennessee and Virginia, as garden

Forsythia viridissima (see page 21)
Gardenia, continued

subjects. They are admirable house plants on account of the durability of the flowers.

Gardenia jasminoides ( $G$. florida). CAPE JASMINE. The double wax-like flowers, which are exquisitely fragrant, are greatly in demand for buttonhole bouquets.

G. jasminoides fortunei. LARGE-FLOWERED CAPE JASMINE. Flowers larger than those of the preceding variety. A splendid plant for jardinières.

Either of the Gardenias, vigorous young plants, prepaid, 25 cts. each; larger sizes, purchaser paying transportation, $25 \mathrm{cts}$. and $50 \mathrm{cts}$. each.

\section{Gelsemium}

Gelsemium sempervirens. Carolina Yellow Jasmine. The spring-time glory of this rampant evergreen vine is well known throughout the South, where it is most effectively used in screening arbors and covering unsightly objects. The fragrant bright yellow blossoms, so profusely borne, illuminate the deep green drapery of leafy branches like sunshine and fill the air with subtle perfume. Charming. Hardy as far north as Tennessee and the District of Columbia. Strong plants, prepaid, 25 cts. each ; larger sizes, purchaser paying transportation, 25 cts. and $50 \mathrm{cts}$. each.

\section{Hamamelis}

Hamamelis virginiana. IVITCH Hazel. Late in the autumn, often after the leaves have been killed by frost and when most shrubs are in a quiescent state, the unconventional Witch Hazel brings forth its wealth of singular bright yellow flowers, seemingly in defiance of the

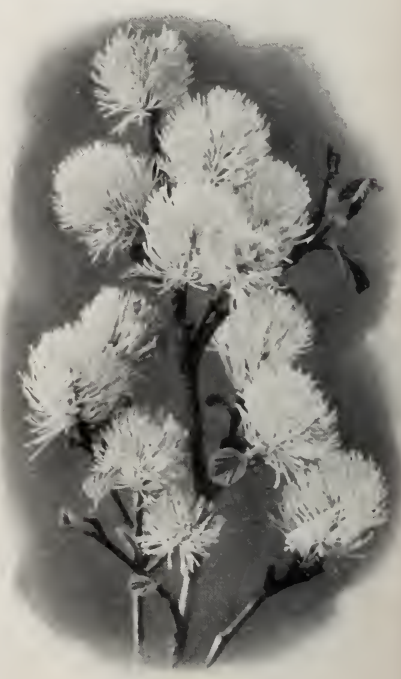

Fothergilla major 


\section{BILTMORE, N.G. W. N W}

Hamamelis, continued approaching chill of winter. It is an extremely hardy large shrub, usually io to 15 feet tall, afiording the latest blossomis of the season. Vigorous young plants, prepaicl, 15 cts. eacls; larger shrubs, purchaser paying transportation, i 5 cts., $25 \mathrm{cts}$. and 50 cts. each.

\section{Hibiscus}

Hibiscus syriacus (Althcea fiutex). ROSE Ol: SHARON. The large and showy flowers of the Althaes, so frecly produced in late summer and at at time when few other shrubs are in blossom, are highly prized and much admired by hosts of planters. And its popularity is well deserved, for few tall shrubs produce such a magnificent display. There are both double- and single-flowered forms, ranging in colors from pure white to rich shades of rose and purple. Your choice of varieties. Strong plants, prepaid, 15 cts. each ; larger sizes, purchaser paying transportation, I5 cts., $25 \mathrm{cts}$. and $50 \mathrm{cts}$. each.
Hydrangea, continued

Hydrangea arborescens. WILD HYDRANGEA. A vigorous upright shrub usually 4 to 6 feet tall. Flowers creamy white, in numerous flat-topped clusters, generally with a few large sterile rays on the marcins. Very hardy and attractive, blossoming profusely in early summer.

H. arborescens sterilis. HiLLs of Sxow. A form of the last with all the flowers ray-like and sterile, resembling a snowball. A splendid shrub, literally loaded with dazzling white blossoms and perpetuating its display for a large part of the summer. A rare and meritorious novelty. Thrifty young plants, prepaid, 75 cts. each; larger sizes, purchaser paying transportation, 75 cts. and \$I each.

H. hortensis. JAPANESE $\mathrm{HY}$ DRANGEA. Beautiful shrubs witli dark glossy green foliage and very showy flowers. They require winter protection in the North, but are extensivel ygrown as pot or tub plants and freely used for decorating piazzas and formal gardens. Hardy in the Southern and Pacific States in the open ground. The color of

Hibiscus syriacus

\section{Hydrangea - The Hydrangeas}

Grand free-flowering, hardy shrubs, with large clusters or panicles of showy flowers. The marvelous display of several varieties, the boldness of inflorescence and duration of beauty, have ranked the Hydrangeas among the most popular garden subjects. They are admirably adapted for border planting, either as specimen plants or in masses; and are most satisfactory and desirable for planting about summer homes and resorts.

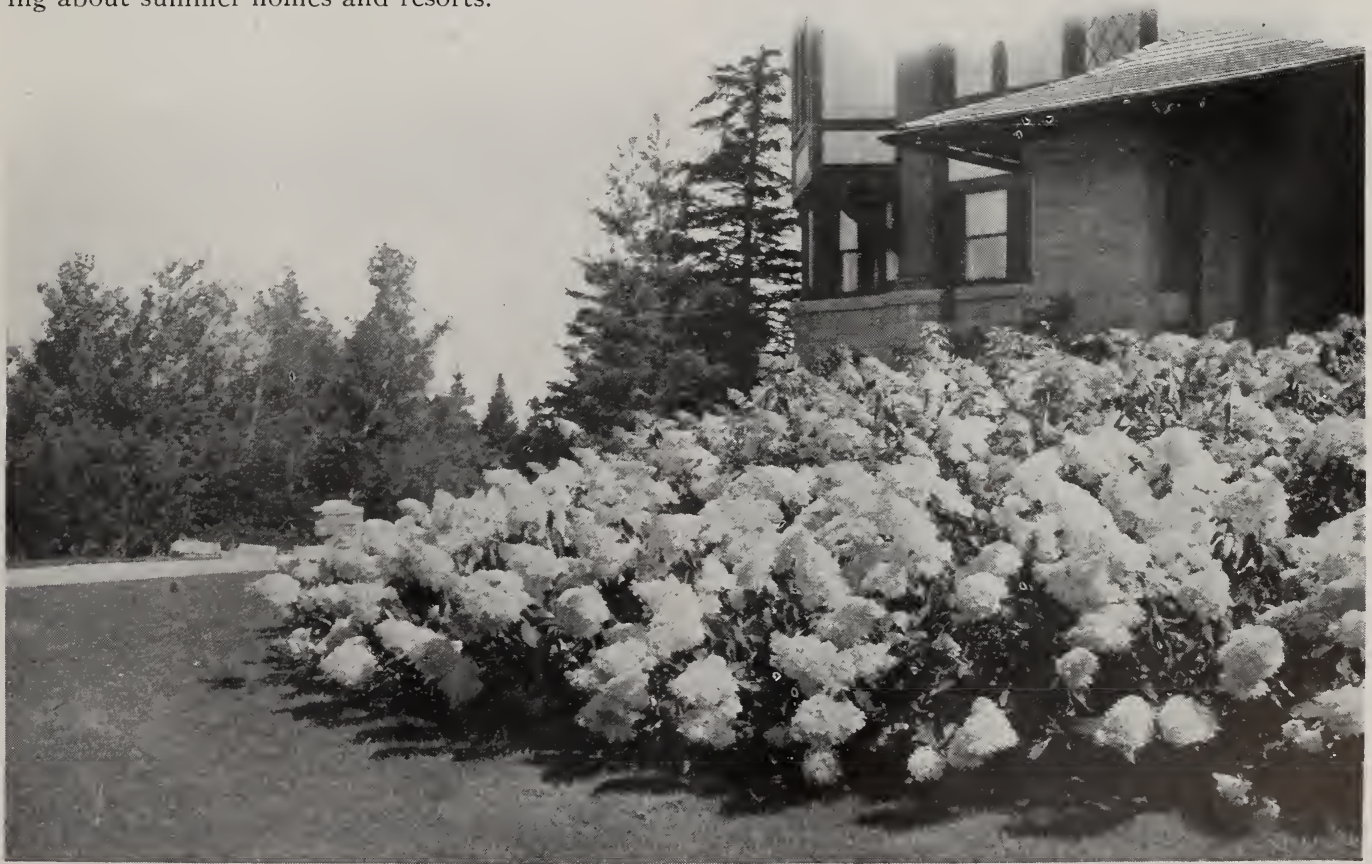

An effective planting of Hydrangea paniculata grandiflora 


\section{Q RILTMORE NURSERY W WE}

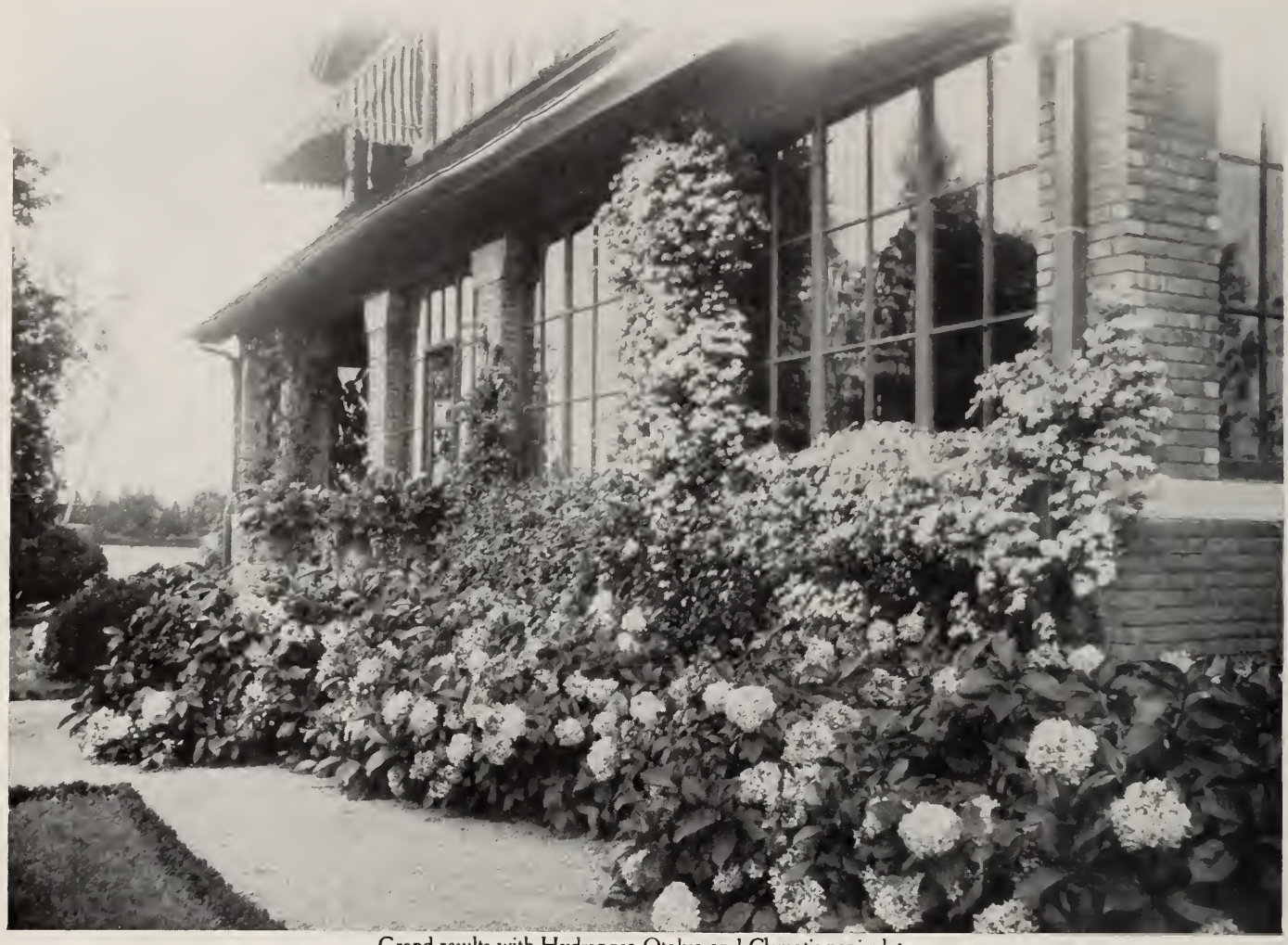

Grand results with Hydrangea Otaksa and Clematis paniculata

Hydrangea, continued

Hydrangea paniculata. PANICLED HydRANGeA. A very hardy tall shrub with numerous panicles of creamy white flowers bountifully flecked with large white rays. The large clusters are 6 to 12 inches long, the sterile flowers changing in age to tones of rose and purple. Very ornamental and graceful, producing charming effects when massed.

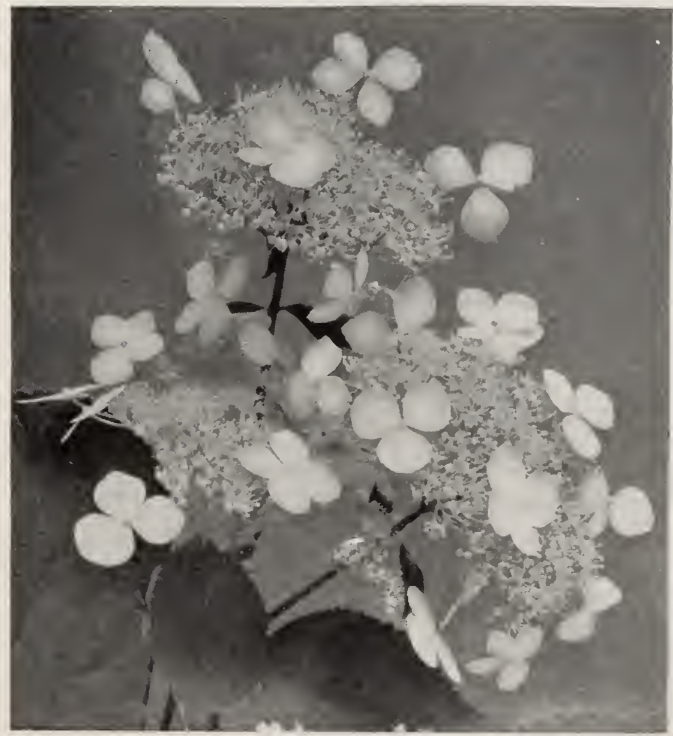

Hydrangea radiata
Hydrangea, continued

Hydrangea paniculata grandiflora. LARGE-FLOWERED HYDRANGEA. Undoubtedly the most popular variety and one of the showiest shrubs in cultivation. The flowers are almost all radiant and sterile, and are produced in mammoth panicles. When fully expanded the flowers are white, but in age assume tones of rose and bronze on the exposed sides. Requires severe pruning in early spring to insure the largest trusses.

H. paniculata praecox. EARLY-FLOWERING HYDRANGE.A. Similar to $H$. paniculata, but blossoms several weeks earlier. By the judicious use of this shrub in connection with its other forms, the floral duration of the Hydrangeas may be considerably extended.

H. quercifolia. O+K-LEAVED HYDRANGEA A remarkably distinct and handsome shrub, the roung branches of which are densely clothed with rusty brown felt-like hairs. Flowers disposed in large panicles, creany white with numerous white or pinkish rays. A beantiful and comparatively rare plant, deserving of every commendation. Strong plants, prepaid, 25 cts. each; larger sizes, purchaser paying transportation, $25 \mathrm{cts}$., 50 cts. and $75 \mathrm{cts}$. each.

H. radiata. Silver-LeAved HYDRANGEA. The leaves of this hardy shrub are silvery white beneath, affording a striking contrast with the deep green of the upper surfaces when moved by the wind. Flowers creamy white, in numerous flat-topped clusters, with several large ray-florets on the margins. Splendid for rocky banks and rock-gardens.

Where not otherwise specified, any of the Hydrangeas as above, prepaid, $15 \mathrm{cts}$. each; larger sizes, purchaser paying transportation, $15 \mathrm{cts} ., 25 \mathrm{cts}$. and $35 \mathrm{cts}$. each.

A collection of six distinct varieties, our selection, but embracing some of the best and showiest forms, strong plants, prepaid, $\$ 1$; larger sizes, purchaser paying transportation, $\$ 1, \$ 1.50$ and $\$ 2$. 


\section{BILTMORE, N.C. Tt TLQ}

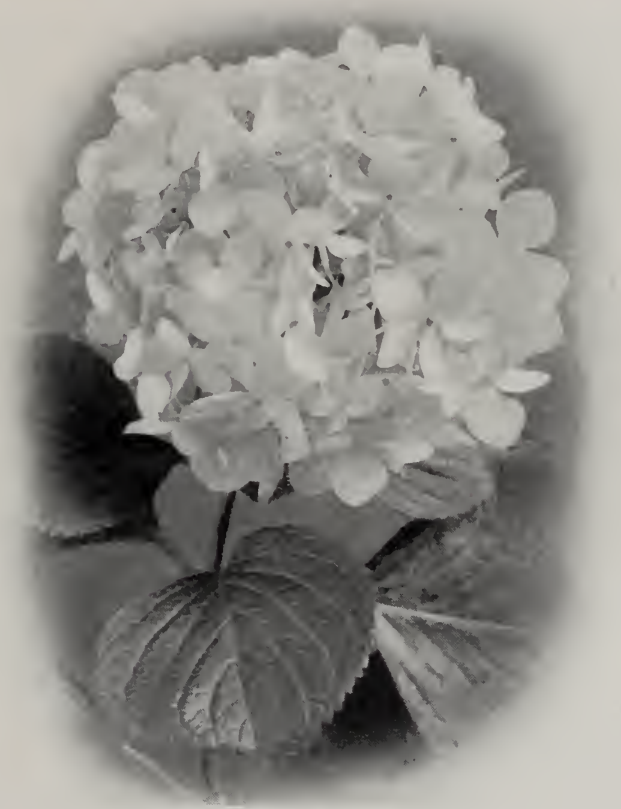

Hydrangea Otaksa (see page 23)

\section{Hypericum - St. John's Worts}

Bright and cheerful are the fuzzy yellow blossoms of the Hypericums, which shine like gold through many weeks of summer-the joy of busy bees that toil with vim and lively action gathering loads of yellow pollen. They are splendid plants for border planting, always pleasant and inspiring, and lend themselves to almost any treatment.

Hypericum aureum. GOLDEN HYPERICUM. LARGEFLOWERED ST. JOHN's IVORT. A glorious free-flowering shrub with golden yellow flowers nearly 2 inches across. The blue-green leaves, persisting until cold weather, form a striking background for the showy blossoms with their hosts of fluffy stamens. Really splendid. Strong plants, prepaid, $25 \mathrm{c}$. each; larger sizes, purchaser paying transportation, $25 \mathrm{c}$. and $35 \mathrm{c}$. each.

H. densiflorum. DENSE-F LOWEREDST. JOHN'S WWORT. A handsome hardy shrub with intricate leafy branches, attaining a height of 3 to $5 \mathrm{ft}$. Flowers very pleasing, bright yellow, produced in compound clusters in bewildering profusion through many weeks of summer. Dainty and attractive.

H. moserianum. Gold Flower. A low and leafy shrub with graceful drooping branches. Flowers shining vellow, 2 inches across, glistening in the sunlight like lustrous golden wax, their centers plumed with almost countless thread-like stamens. Very showy, especially in groups or masses.

H. prolificum. Shrubby St. John's IVort. A vigorous and very hardy shrub with numerous compact branches. Flowers bright yellow, profusely borne in leafy compound clusters that seem to occupy the tips of all the branches and cause the plant to shine in the radiance of its inflorescence. One of the best.

Where not otherwise noted, any of the St. John's Worts, vigorous young plants, prepaid, $15 \mathrm{cts}$. each; larger shrubs, purchaser paying transportation, $15 \mathrm{cts}$. and $25 \mathrm{cts}$. each.

SPECIAL OFFER. A collection of three varieties of St. John's Worts, no two alike, our selection, vigorous plants, 35 cts.; larger plants, purchaser paying transportation, $35 \mathrm{cts}$. and $50 \mathrm{cts}$.

\section{Itea}

Itea virginica. VIRGINiAN WILlow. Strange indeed, that this dainty shrub is so little known or recognized, for when in flower, or when arrayed in autumn colors, it is a thing of joy and beauty. It is a vigorous, freeflowering shrub some 3 or 4 feet tall, with white fragrant blossoms in numerous long racemes in early summer. The bright and lustrous foliage turns to vivid shades of red in autumn, the intensity of which is simply grand. Strong plants, prepaid, 15 cts. each; larger shrubs, purchaser paying transportation, 15 cts. and $25 \mathrm{cts}$ each.

\section{Jasminum - The Jasmines}

Renowned in literature and by tradition handed down as the symbol of subtle fragrance and mystic grace, the Jasmines appeal to all with rare charm and striking emphasis. And the legend of their brightness is not lacking. The graceful arching branches, laden with their pure and dainty blossoms, combine to make both in outline and in splendor a picture of surpassing beauty. In sections where the climate is too severe, they are often and most effectively used as house plants.

Jasminum humile. ItAlian Yellow JASMine. A bright and pretty shrub with numerous angled branches clothed with leaves of deep and lustrous green, quite evergreen in the South. Flowers bright yellow in dainty clusters, glistening in the high light of their waxy petals. Hardy as far north as Tennessee and Maryland, and on the Pacific Coast.

J. nudiflorum. NAKED-FLOWERED JASMINE. An extremely graceful shrub with numerous drooping greenbarked branches, and the hardiest of all the Jasmines. Flowers bright yellow, opening very early in spring, or on warm days throughout the winter. Indeed, so precorious are the blossoms that, from Christmas-tide to Easter, a few days' placid sunshine flames the bushes into floral life and beauty. Hardy as far north as Philadelphia, or with protection from bleak cold winds, to Missouri and New York.

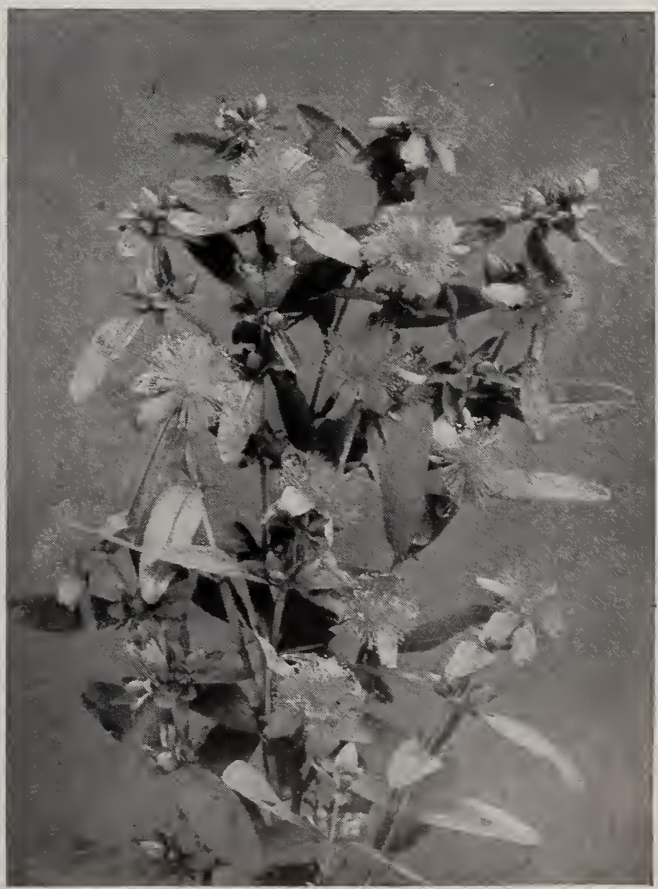

Hypericum prolificum 

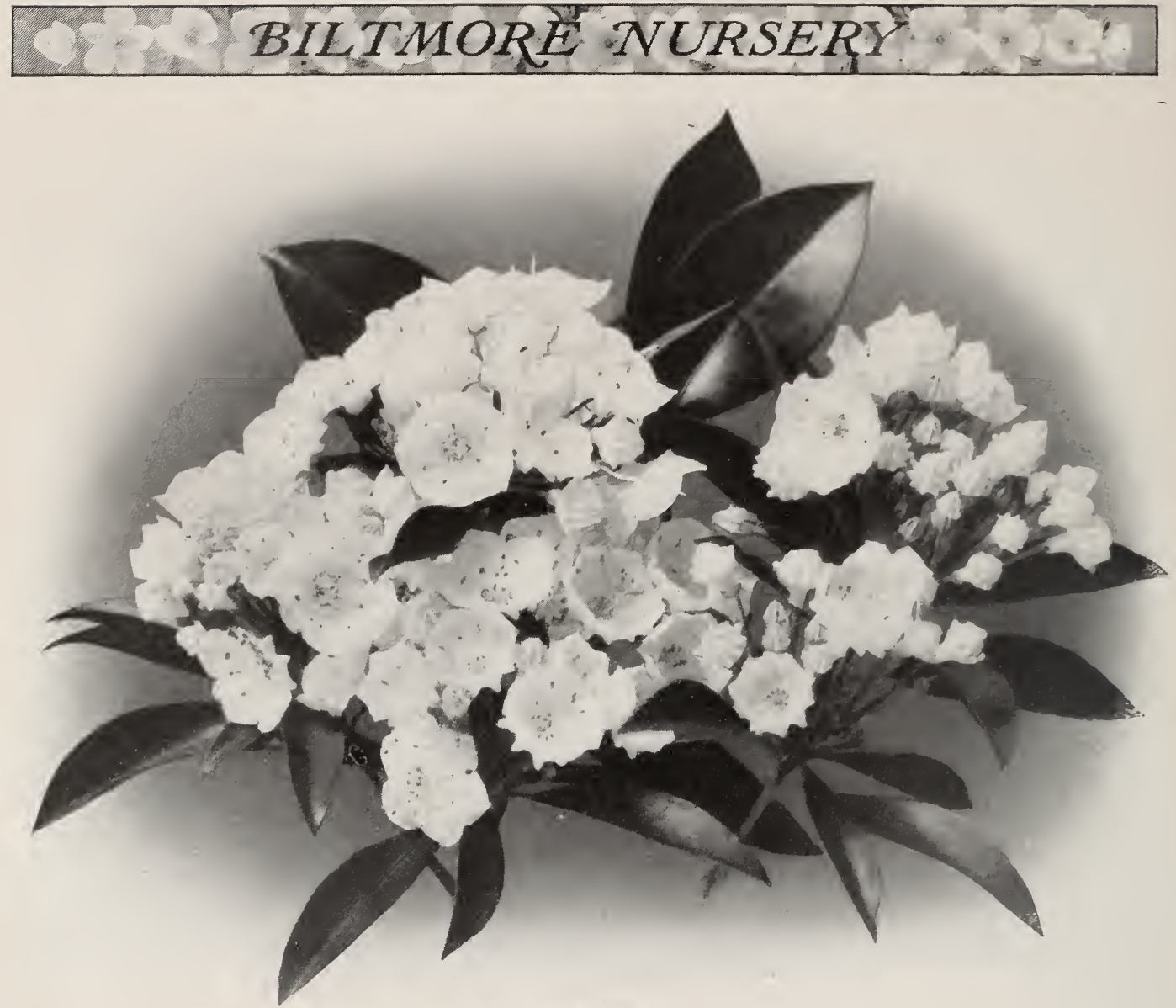

Kalmia latifolia

Jasminum, continued

Jasminum officinale. TRUE JASMINE, or JESSAMINE. This is the classic species and the true Jessamine of literature. A charming, graceful shrub with long and numerous branches, clothed with glossy dark green foliage. Flowers pure waxy white, deliciously fragrant, the perfume of which pervades the whole atmosphere of their enviromment. Hardy South, and as far North with protection, as Tennessee and Maryland. Splendid for a jardinière.

Any of the Jasmines, strong plants, prepaid, 15 cts. each ; larger sizes, purchaser paying transportation, $15 \mathrm{cts}$. and $25 \mathrm{cts}$. each.

SPECIAL OFFER. One each of the above, three strong plants, prepaid, 35 cts.; larger sizes, purchaser paying transportation, $35 \mathrm{cts}$. and $55 \mathrm{cts}$.

\section{Kalmia . The Ameri- can Laurels}

Who has not surrendered to the charm and mystic beauty of the Laurels? Surely only a heart of ice or stone. Their pretty flowers, blushing in shades of pink and rose and outlined in exquisite form, present a type of grace and beauty unsurpassed. With all these enchanting traits, and more, can you pass them by? In partial shade and porous,

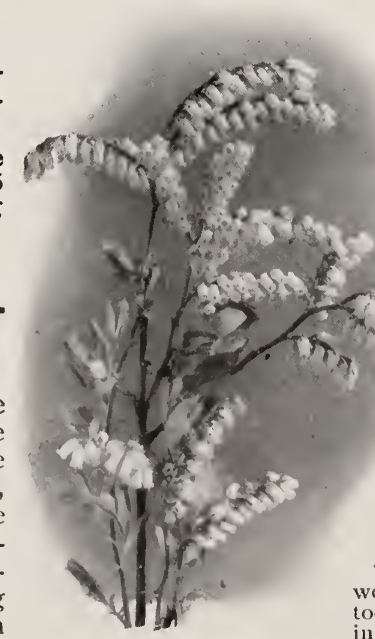

Leucothoe (see page 28)
Kalmia, continued

loamy soil, especially one containing leaf-mould or woods earth, they thrive luxuriantly, enduring the cold of winter and the heat of summer. A mulch of forest leaves or pine needles is beneficial, preventing the rapid evaporation of moisture and sudden changes of temperature from affecting the dense mat of roots.

Kalmia angustifolia. NARROWLEAVED LAUREL. A dwarf evergreen shrub of extreme hardiness. Flowers wheel-shaped, decp rose with crimson marks, borne in great profusion. Thrifty young plants, prepaid, $25 \mathrm{cts}$. each; larger sizes, purchaser paying transportation, 25 cts. and $50 \mathrm{cts}$. each.

K. latifolia. MOUNTAIN LAUREL. Calico Bush This matchless Laurel is without question or doubt one of the most beautiful and attractive of the broad-leaved evergreen shrubs, botl on account of its dark green and lustrous foliage, and for its masses of glorious pink or rose-colored flowers which appear in lavish profusion in early summer. Strong plants, prepaid, 5o cts. each ; larger sizes, purchaser paying transportation, 50 cts.. 75 cts. and \$I each.

The Kalmias I bought of you three years ago did wonderfully well. I did not lose a single plant and today they are $3 \frac{1}{2}$ to 4 feet high. They were planter in sandy soil on the Cape and their growth has simply been wonderful.-S. M. WEk1.D, Boston, Jilly 22, I907. 


\section{BILTMORE, N:C. W.}

\section{Kerria}

Kerria japonica (Corchorus japonica). Globe Flower. A charming and attractive old-fashioned shrub with slender green-barked branches, and pretty bright green foliage which fades in autumn with glorious shades of gold and yellow. The numerous large and showy blossoms of bright rich yellow, either in single- or double-flowered forms, were often classed among the choicest gems of the gardens of long ago. And time has not dimmed its beauty an iota, though, perhaps, its popularity may have seemed to wane. Your choice of forms. Thrifty young plarits, prepaid, $15 \mathrm{cts}$. each; laryer shrubs, purchaser paying transportation, $15 \mathrm{C}$. and $25 \mathrm{C}$. each.

\section{Kœlreuteria}

Koelreuteria paniculata. VARNISH TREE. This thrifty, hardy, small tree is susceptible of the most pleasing combinations with shrub plantations, lending by its handsome foliage and large panicles of yellow flowers a succession of tints and shades until autumn flames the leaves with brilliant tones of gold, coppery red and bronze. We recommend the Kolreuteria with extreme confidence believing that its admirable qualities will place it in high rank in the planter's estimation. Vigorous young plants, prepaid, 25 cts. each ; larger sizes, purchaser paying transportation, 25c., 75c. and \$I each.

The plants arrived in first-class condition and that we are satisfied need not be said.-L. E. BENTON, American Fruit and Produce Company. S. A., Mexico City, Mexico. April 6, 1908 .

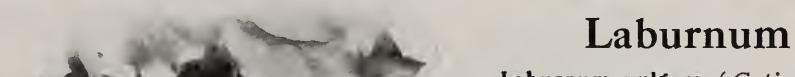

Laburnum vulgare (Cytisus laburnum). GOLDEN CHAIN. This is the Bean Tree of European gardens, with handsome pea-shaped flowers borne in long, silky, drooping racemes, so aptly described by Cowper as " rich in streaming gold." The splendor of this slender small tree few rivals can surpass, when, in late spring, it is a mass of graceful pendent blossoms - the attraction of busy bees and butterflies. It thrives best in moist fertile soil, and is more luxuriant in the North than in the South. Thrifty young plants, prepaid, $25 \mathrm{cts}$. each ; larger sizes, purchaser paying transportation, 25 cts. and $50 \mathrm{cts}$. each.

\section{Lagerstrœmia}

Lagerstroemia indica. CRAPE MYRTLE. The pride of many southern gardens, resplendent in rich and lavish floral setting, is often a group of plants of the beautiful Crape Myrtle with transcendent crowns of crinkled and ruffled blossoms. Oh the joy of matchless beauty, of colors soft, but bright, glimmering in the sunshine of a cloudless sky ! One must see to fully grasp the charming aspect. The flowers, produced in profuse panicles in summer, continue to expand for several months. There are forms with crimson, pink, white and purple blossoms. It makes a splendid house plant. Hardy as far North as Memphis and Baltimore. Vigorous young plants, prepaid, I5 cts. each; larger sizes, purchaser paying transportation, $15 \mathrm{cts}$., $25 \mathrm{cts}$. and $35 \mathrm{cts}$. each.

I beg to state that the nursery stock arrived in fine shape. I have been buying it now for 4 or 5 years and have never gotten better packed stuff. Yours was perfect in every respect, and want to thank you and say further that thank you and say further that
in future you will get my entire in future you will get my entire W. A. LANKFORD, Charlottesville, Va., April 10, 1908

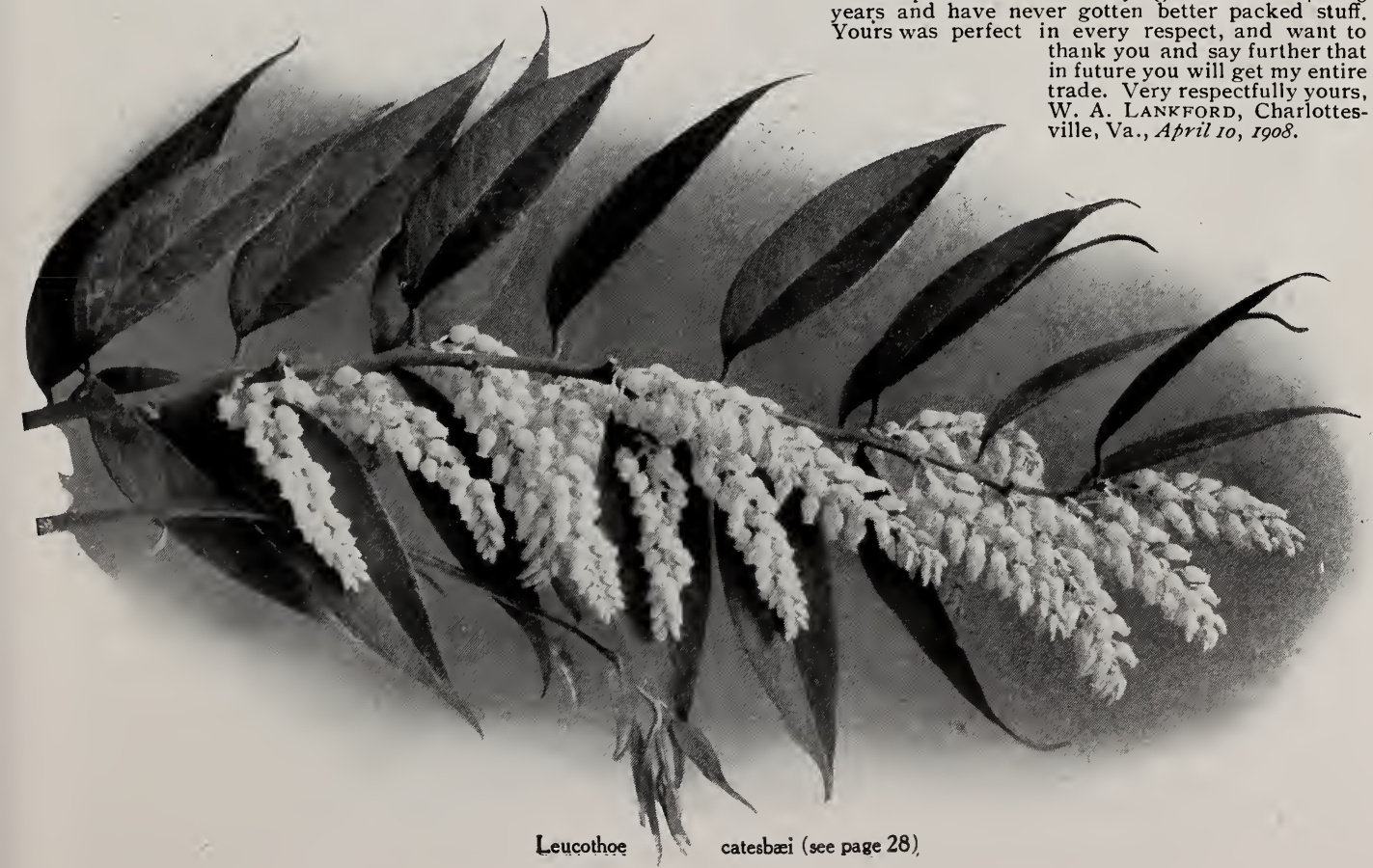




\section{Q BILTMORE NURSERY N WEO}

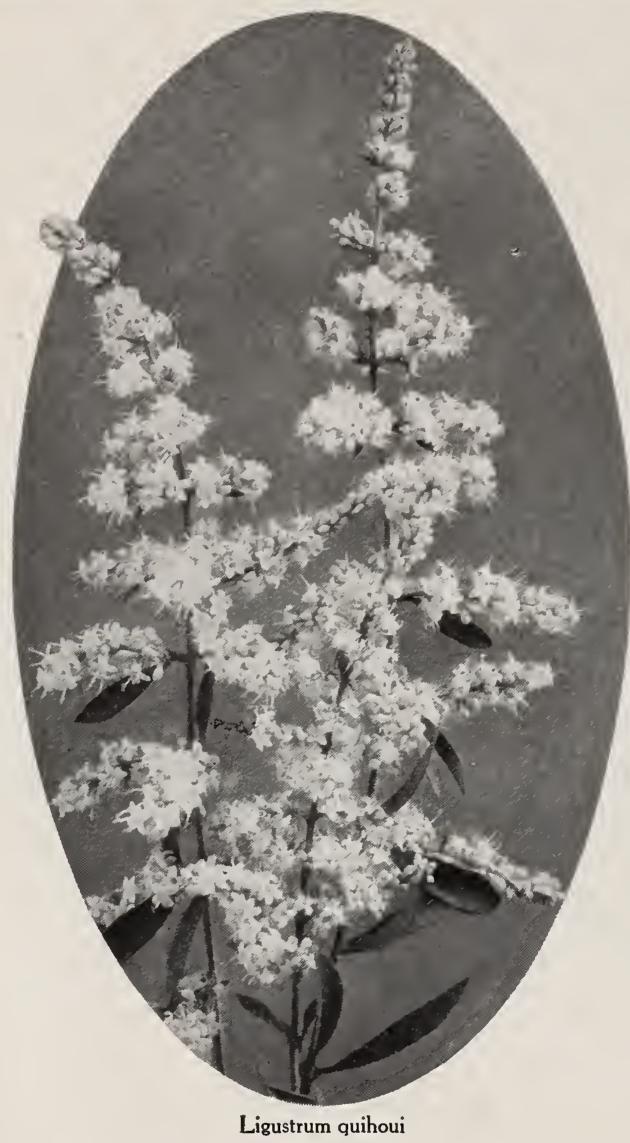

Leucothoë · The Leucothoës

The fascination attending the cultivation of these unusual and meritorious shrubs is freely expressed by enthusiastic planters. As they are comparatively new subjects in many gardens, a few words concerning their simple requirements may help many in attaining the best results. They delight in a moist, porous soil, especially one containing leaf-mould or woods earth. A mulch of forest leaves or similar material adds greatly to their comfort. In the selection of a site, a cool, northern exposure should be chosen, but, failing in this, with sufficient moisture and partial shade, excellent results may be obtained.

Leucothoe catesbaei (Andromeda catesbci). EverGREEN LEUCOTHOE. Few plants in recent years have won such a wave of popular favor as this graceful, evergreen shrub. The leaf-sprays are extensively used as Christmas greens, for the lustrous dark green leaves, borne in fern-like regularity on the arching stems, assume in winter brilliant shades of bronze and vinous red. The creamy white flowers, produced in bewildering profusion in late spring or early summer in pendent or drooping racemes, are both fragrant and extremely beautiful. Charming.

L. racemosa (Andromeda racemosa). Deciduous LEUCOTHOE. A rigid shrub with 1 pright branches, usually growing 3 to 4 feet tall. The leaves are bright green, appearing after the flowers, and fade in autumn with dazzling and intensely vivid tones of red and scarlet. The white blossoms open in spring, and are dis-
Leucothoë racemosa, continued

posed in numerous one-sided racemes 2 to 3 inches long. A rare and interesting plant.

Either of the Leucothoes, vigorous young plants, prepaid, 25 cts. each; larger sizes, purchaser paying transportation, $25 \mathrm{cts}$., $35 \mathrm{cts}$. and $50 \mathrm{cts}$. each.

\section{Ligustrum . The Privets}

"What! Privets as flowering plants?' Yes; yes indeed. The varieties following are remarkably beautiful when loaded, as they are each recurrent season, with a galaxy of flowers transcendent in their brightness and profusion. With seeming indifference as to soil or environment, they impress one with their wonderful traits of adaptability. Try them as flowering shrubs: if your knowledge is limited to their use as hedge plants, you have missed their inherent charm.

Ligustrum quihoui. LATE-FLOWERING PRIVET. A splendid shrub with spreading branches, and the showiest and latest-flowering species. Leaves dark lustrous green, persistent in the South, half-evergreen in the North. Flowers creamy white, in large and showy panicles, appearing, more or less, all summer long. Berries blue-black, with an iridescent bloom. Rare in cultivation; its sterling merit in groups or as single specimens apparently is almost unknown.

L. sinense. Chinese Privet. A tall and graceful shrub with dark green and glossy leaves, fully evergreen in the South. Flowers in bewildering profusion in late spring or early summer, creamy white, disposed in numerous fluffy panicles. Berries blue-black, with an iridescent bloom, literally covering the branches, which bend in willowy outlines with the burden of their loads Really grand for informal groups or as specimen plants.

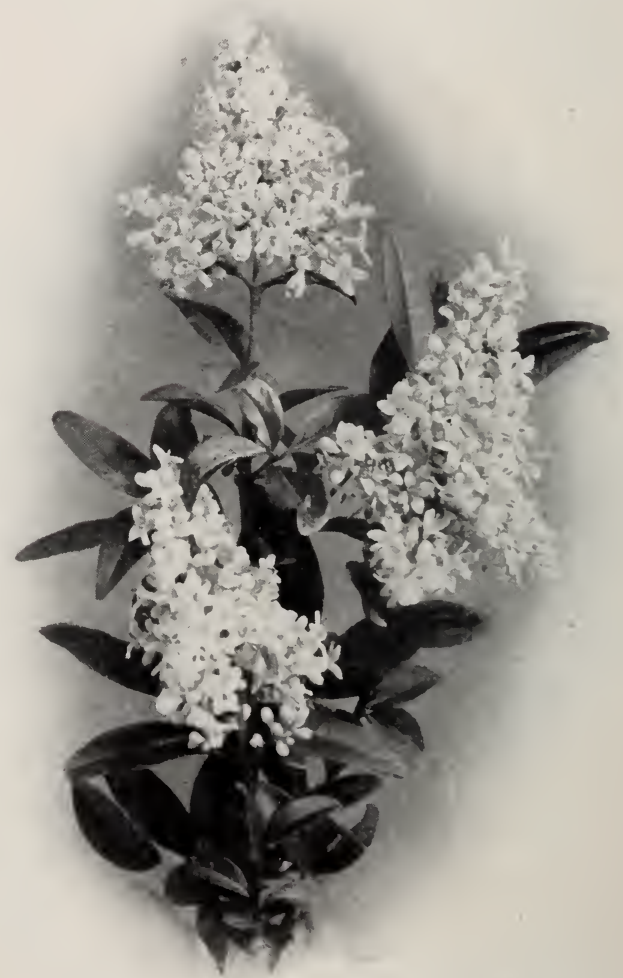

Ligustrum vulgare (see page 29) 

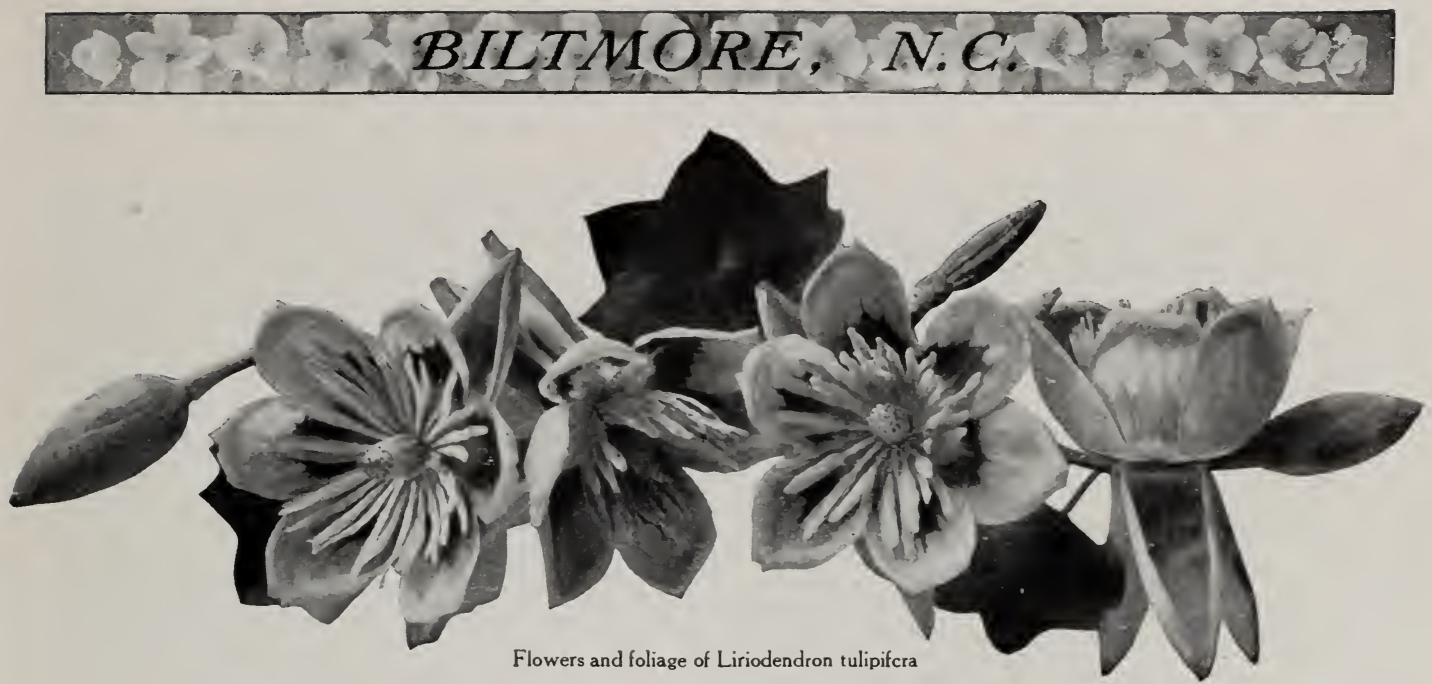

Ligustrum, continued

Ligustrum vulgare. EURopeax Privet, or Prin. A tall and very hardy plant with dark green and lustrous half-evergreen foliage. Flowers white, in dense upright clusters from the tips of the twigs and branches. Berries black, shining. A good old-fashioned shrub. Strong plants, prepaid, 15 cts. each ; larger shrubs, purchaser paying transportation, $15 \mathrm{cts}$. and $25 \mathrm{cts}$. each.

Where not otherwise noted, thrifty plants, prepaid, 25 cts. each; larger sizes, purchaser paying transportation, $25 \mathrm{cts}$. and $50 \mathrm{cts}$. each.

SPECIAL OFFER. One each of the above Privets, strong plants, prepaid, $50 \mathrm{cts}$; larger sizes, purchaser paying transportation, $50 \mathrm{cts}$. and $\$ 1$.

\section{Liriodendron}

Liriodendron tulipifera. TULIP TREE. Unsurpassed for lawns and avenues, by reason of its handsome foliage and wonderfully large tulip-like flowers, this stately, hardy, rapid-growing tree is deserving of highest esteem. Its lofty pyramidal crown, so bountifully furnished with bright and lustrous foliage, is adorned in late spring with numerous cup-shaped flowers of yellow-green, blotched with orange. Remarkably beautiful, grand and inspiring. Grows best in deep rich soil and succeeds best when transplanted in the spring. Thrifty young plants, prepaid, $25 \mathrm{cts}$. each; larger trees, purchaser paying transportation, 25 cts., $50 \mathrm{cts}$. and $75 \mathrm{cts}$. each.

\section{Lonicera}

\section{The Honeysuckles}

The fragrance of Honeysuckles, so sweet and enchanting, to many of us at least, recalls a bright and happy garden scene, or else a bowered porch where warmth and sunshine lurk and busy bees toil with humming wings. Their charm is all-enduring, and their cheerful home-like aspect most inspiring. Few plants afford greater versatility or offer less resentment to conditions of soil, climate or exposure. When in doubt, plant
Honeysuckles. Both the bush forms and the vines are splendid.

Lonicera fragrantissima. EARLY FRAGRANT HONEYSUこKLE. A large shrub with numerous spreading branches and long-persistent bright green leaves that rarely fall before midwinter. Responding to the earliest call of Spring, the creamy white, or eventually light yellow blossoms burst their buds and fill every breath of air with exquisite fragrance. A grand shrub, eventually 6 to 8 feet tall. Should be in every garden.

L. heckrotti. HeCkRotT's Hoversuckle. A shrubby vine with short, sometimes twining stems. The fragrant purple blossoms, borne in great profusion, make an enduring and an inspiring display. Splendid for massing. Strong plants, prepaid, $25 \mathrm{cts}$. each: larger vines, purchaser paying transportation, $25 \mathrm{cts}$. and $35 \mathrm{cts}$. each. L. japonica ( $L$. halleana) JAPANESE HoNeYSUCKLE. A rampant evergreen climber of inestimable value for covering arbors, trellises and unsightly objects, and as a ground cover on steep banks and rocky exposures. Flowers white, changing to yellow, deliciously fragrant, borne in bewildering profusion in summer, and in less display at intervals during the remainder of the growing season. One of the best.

L. morrowi. JAPANESE Bush HoNersuckLe. A shrub with wide-spreading branches, 4 to 6 feet tall. Flowers pure white, changing to yellow, sweetly fragrant, freely produced in early spring. The bright red berries which bend the heavy laden shoots in summer, are simply gorgeous. Highly commended.

L. periclymenum belgica. MONTHLY FRAGRANT HONEYSUCKLE. This, the finest form of the Woodbine, with fragrant bright red flowers freely produced throughout the summer, is a vigorous and hardy vine of wide popularity; a grand and meritorious variet $\mathrm{r}$ and one that is almost constantly in bloom. Strong plants, prepaid, 25 cts. each; larger vines, purchaser paying transportation, 25 cts. and $35 \mathrm{cts}$. each. 


\section{Q. PILTMORE NURSERY N WE}

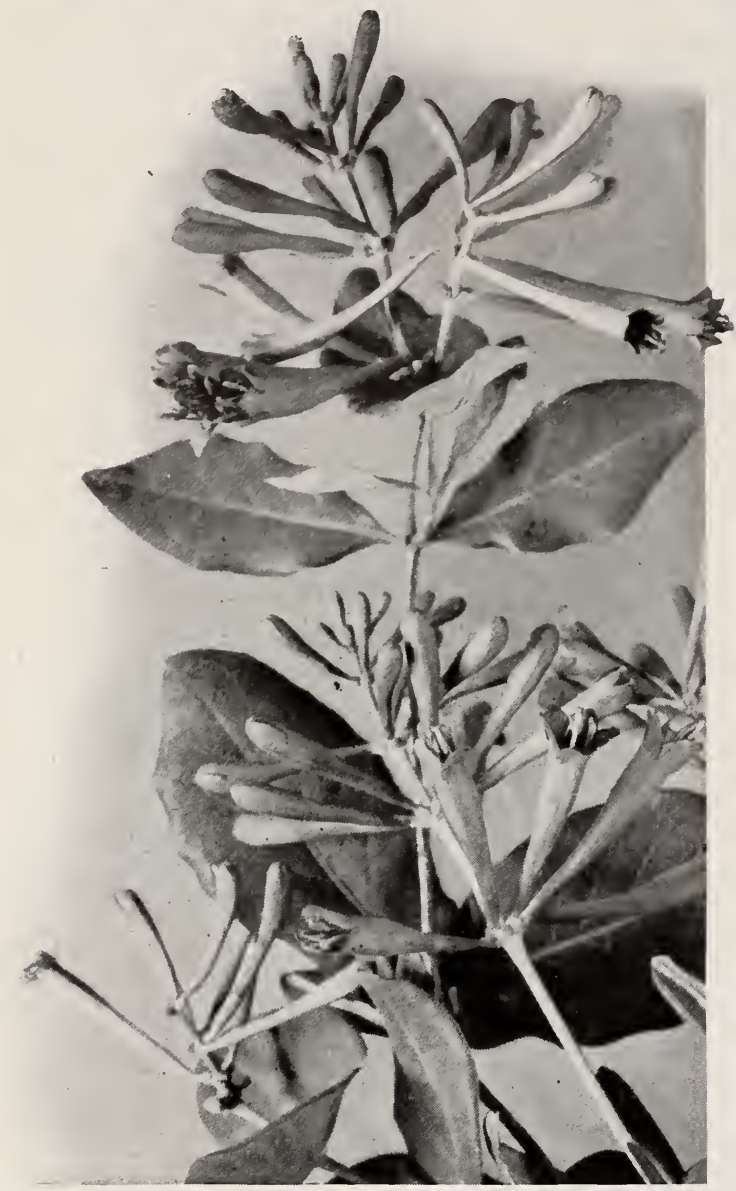

Lonicera sempervirens

\section{Lonicera, continued}

Lonicera sempervirens. TRUMPET, or CORAL HONEY SCCKLE. A high-climbing vine with glorious large scarlet flowers blazing like torches in their fiery array. Both in profusion of blossoms, in brilliant display, hardiness and great vigor, this splendid vine is une $x$ celled among its class for porches and verandas. Strong plants, prepaid, $25 \mathrm{cts}$. each; larger vines, purchaser paying transportation, $25 \mathrm{cts}$. and $35 \mathrm{cts}$. eacli.

L. tatarica. TARTARIAN HONEYSUCKLE. A large and very vigorous shrub often 8 to so feet tall. Flowers white or pink, fragrant, borne in great profusion late in spring. The red or orange berries, which fairly glow in myriad numbers, give wonderful color and vivacity to the summer aspect. Very fine.

Any of the Honeysuckles, unless otherwise noted, strong plants, prepaid, $15 \mathrm{cts}$. each; larger plants purchaser paying transportation, $15 \mathrm{c} ., 25 \mathrm{c}$. and $35 \mathrm{c}$. each.

SPECIAL OFFER. A collection of six Honeysuckles, three of the climbing and three of the shrubby forms, no two alike, our selection of varieties, strong plants, prepaid, $\$ 1$; larger sizes, purchaser paying transportation, $\$ 1$ and $\$ 1.50$.

\section{Magnolia - The Magnolias}

No other group of trees embraces such wealth of floral treasures - such effort on the part of Nature to excel! Beauty, gorgeous beauty, exquisitely fashioned in every petal, every flower, proclaims supreme achievement. Every species is characterized by the splendor of its flowers; some blossoming in earliest spring before the leaves appear, some when the foliage is almost fully grown, while others are evergreen. The larger part are hardy and extremely durable. To do without them is only to deprive yourself of the showiest of all flowering trees; they are indispensable.

Magnolia conspicua. Yulan. A grand lawn or garden tree, literally covered with blossoms in early spring, which expand before the leaves unfold. The sweetscented pure white flowers measure about 6 inches across. Usually branched very low.

M. fraseri. FRASER's MAGNOLIA. A handsome hardy tree of great merit. The creamy white, sweet-scented flowers, 6 to 8 inches in diameter, appear in early sum-

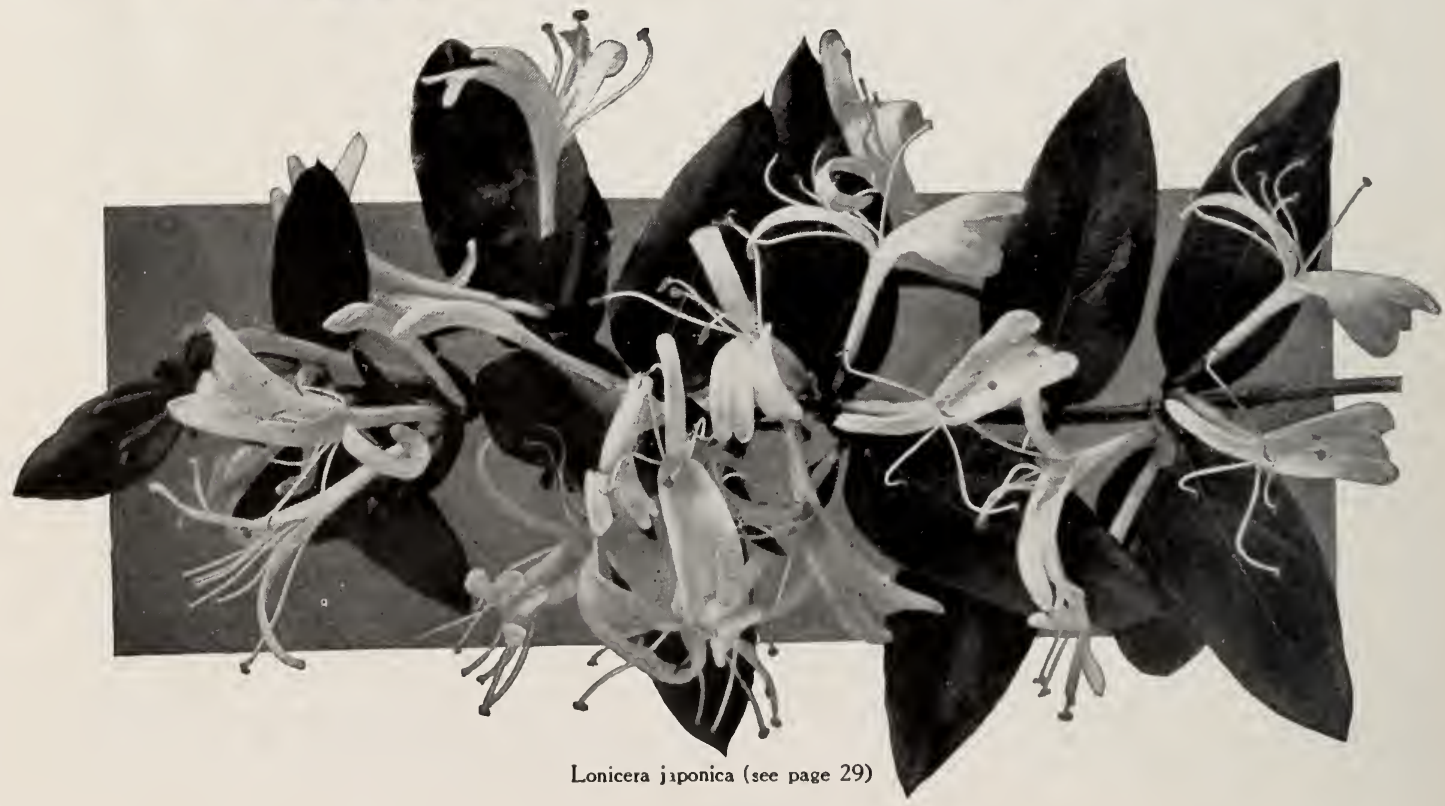




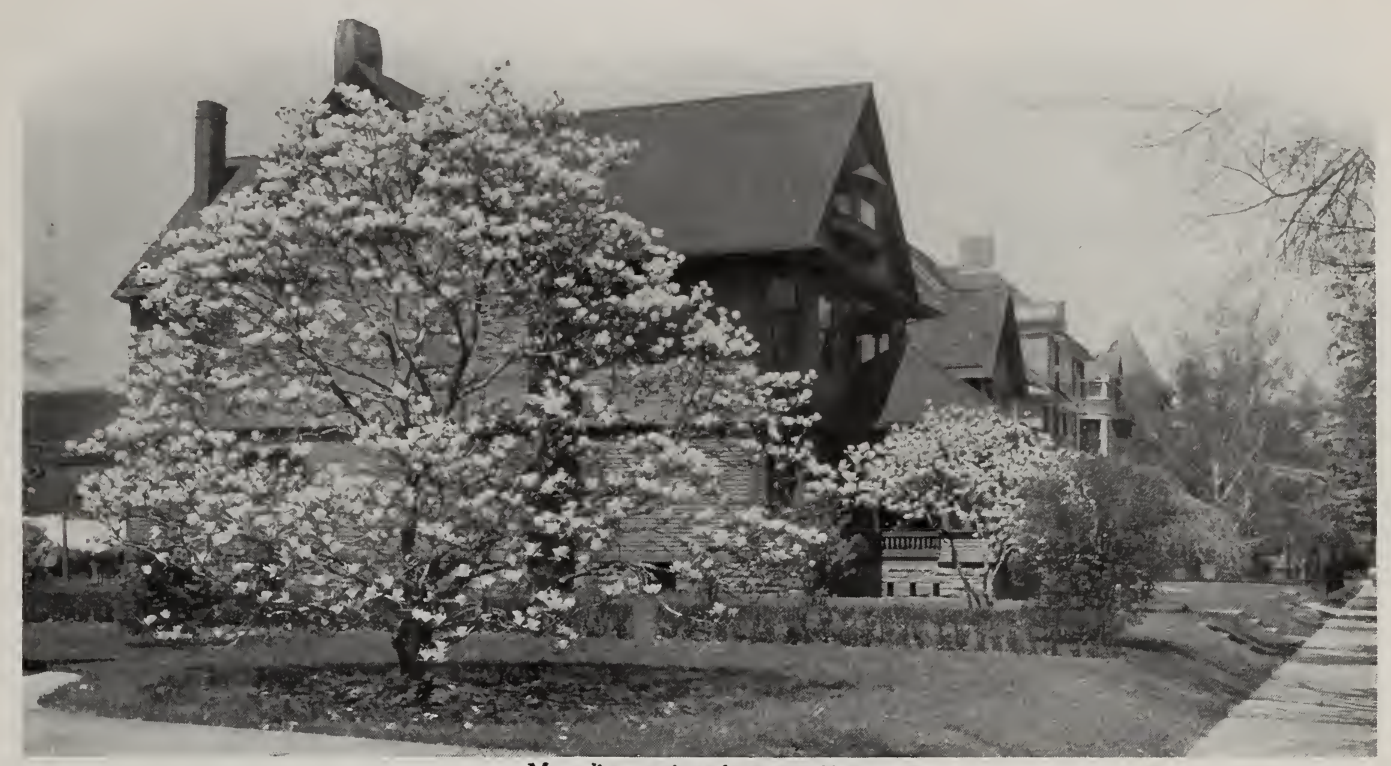

Magnolia conspicua (see page 30)

Magnolia fraseri, continued

mer from the tips of leafy shoots, which form a bold and handsome background. The leaves are deciduous, bright green, with auricles at the base. Thrifty young plants, prepaid, $50 \mathrm{cts}$. each ; larger sizes, purchaser paying transportation, $50 \mathrm{cts}$. and $\$_{\mathrm{I}}$ each.

M. glauca. Siveet, or IVhite BAy. A slender tree or large shrub, evergreen in the South, tardily deciduous in the North. The green and lustrous leaves, of leathery texture, are beautifully whitened on the lower surface. Flowers creamy white, sweet-scented, 2 to 3 inches across, blossoming for several weeks in late spring and early summer. Thrifty young plants, prepaid, $50 \mathrm{cts}$. each; larger sizes, purchaser paying transportation, 50 cts. and $\$ \mathrm{I}$ each.

M. grandiflora. Southern MAgnolia. A grand and stately tree, everywhere associated with typical Southern homes and gardens. The thick evergreen leaves, bright green and glossy on the upper side, and coated with rusty hairs beneath, are magnificent in effect and form an imposing background for the large waxy white

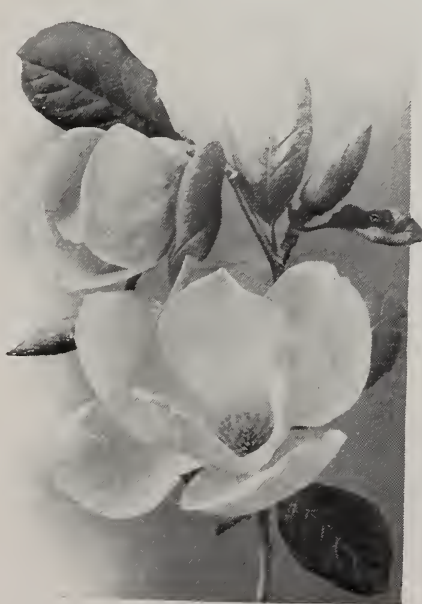

Magnolia soulangeana blossoms which exhale a rich and heavy perfume. The flowers are 6 to 8 inches in diameter and open during late spring and summer. Will stand considerable cold, but not trustworthy north of Philadelphia and Memphis. Vigorous young plants, prepaid, 75 cts. each; larger trees, purchaser paying transportation, 75 cts. and \$I each.

M. kobus. JAPANESE MAGNOLIA. A narrow pyramidal tree, and nine of the hardiest of the early - flowering species. Blossoms pure white, 4 to 5 inches across, appearing before the leaves unfold. Our stock is propa-
Magnolia kobus, continued

gated from an unusually floriferous strain and is highly recommended.

M. macrophylla. Great-LEAved Magnolia. A symmetrical tree with stout wide-spreading branches, producing enormous leaves, 20 to 30 inches long and 9 to Io inches wide. The huge flowers are Io to 12 inches across, creamy white and very fragrant. A beautiful and extremely distinct hardy species. The silver-gray of the lower surfaces of the reaves, when moved by the wind, is very striking and effective.

M. obovata ( $M$. purpurea and $M$. discolor). PURPLE MAGNOLIA. In cultivation usually a large shrub with upright branches. Flowers cup-shaped, purple outside, paler within, appearing when the leaves begin to unfold. Thrifty young plants, prepaid, 50 cts. each ; larger sizes, purchaser paying transportation, $50 \mathrm{cts}$. and \$I each.

M. soulangeana. SOULANGE's, or HyBRID MAGNOLIA. A large shrub or small tree of garden origin and regarded as a hybrid between $M T$. obovata and $M$. conspicua. Flowers large, cup-sliaped, white, more or less suffused with rose or pink; fragrant. Very hardy and showy. Decidedly one of the best. The blossoms appear before the leaves and are borne in wonderful profusion. There are several distinct forms, differing chiefly in the shades of color and time of blossoming.

M. stellata.

MAGNOLIA. A hardy. free-flowering smail tree or shrub, producing a galaxy of starry blossoms in earliest spring. The sweet-scented white flowers, with numerous, often reflexed narrow petals, are ex-

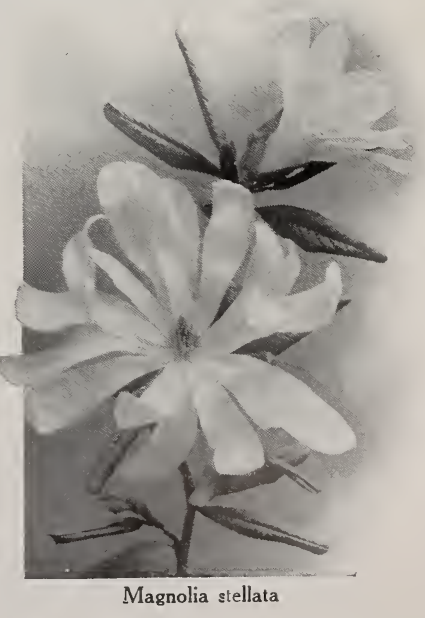




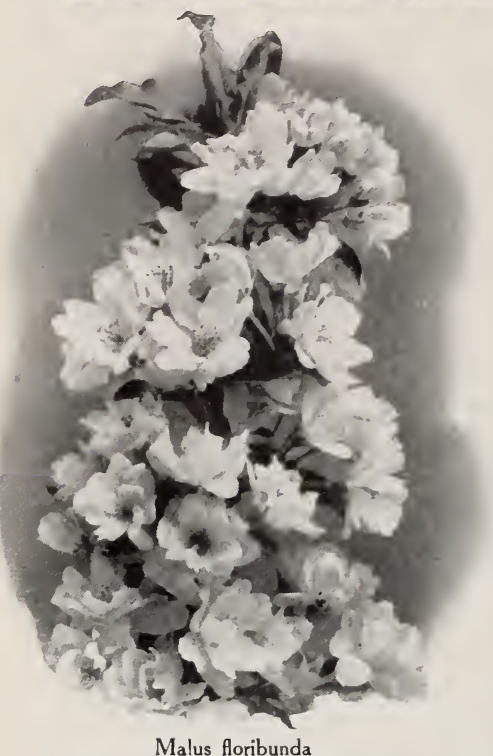

Malus angustifolia, continued nearly round, an inch or less in diameter, spicy - fragrant, often used for preserves. Rarely cultivated, but one of the very best.

M. baccata. SIBERIAN FLOWERING CRAB. A small symmetrical tree with a close dense crown. Flowers appearing with the leaves, borne on long and slender pedicels, white or slightly pink, sweet-scented. Hardy and beautiful. Fruit about the size of a cherry, yellow or ruddy cheeked.

M. coronaria. WILD CRABAPPle. A spiny-branched small tree forming a symmetrical round head. Extremely handsome and hardy. Flowers very fragrant, pink or rosecolor, produced in numerous five- to six-flowered clusters. Fruit yellow-green, fragrant, waxy and translucent at maturity, much esteemed for preserves. A meritorious species.

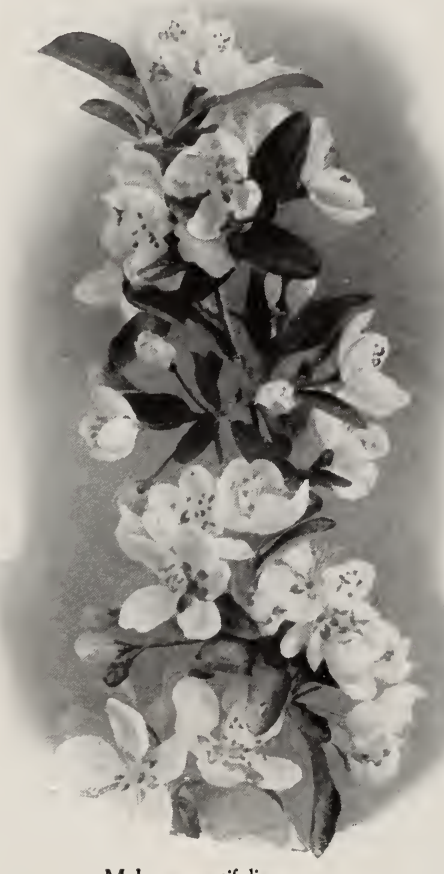

Malus angustifolia

M. floribunda. FLOWERING CRAB. A shrub or small tree of shapely outline. Flowers rose or rose-red, produced in great profusion, sweetscented. Fruit about the size of a pea, on long slender pedicels. A grand specimen plant and one of the best of the spring-flowering trees. Should be included in every collection.

M. floribunda parkmani ( 1 . halleana). PARKMAN'S CRAB. A form with beantiful semi-double rose-colored flowers. Greatly admired and everywhere a favorite.

M. floribunda schiedeckeri. DOUBLE-FLOwERING CRAB. Flowers double, bright rose, of great substance and durability. Splendid for cut-flowers. Thrifty young plants, prepaid, $75 \mathrm{cts}$. each; larger sizes, purchaser paying transportation, 75 cts. and \$1.50 each.

M. ioensis bechteli. Bechtel's Double-Flowering Crab. One of the inost remarkable of flowering trees, possessing extreme hardiness perfection of outline and the acme of floral beauty. The large and very double flowers resemble dainty little roses, of an exquisite shade of pink, with deeper blushes towards the unfolding centers; sweetly fragrant. Worthy of a place in any garden. At least let this one appear on your order.

M. spectabilis. Chinese Flowering CRAB. A small, shapely tree; hardy, handsome and early-flowering. Flowers coral-red in the bud, pink or rose when fully expanded, delightfully fragrant. Superb.

\section{Malus - Flowering Crab-Apples}

With perfume laden-sweet fragrance with every breath wafted here and there by Spring's soft air; with harmony of colorblushing pink and rose from opening bud to falling flower so bright and fair; this is the call of the Wild Crab-Apple. The answer, gentle reader, you know too well, for who has not responded, Their dainty flowers, with enticing sweetness, make fast friends everywhere. They are very hardy and thrive in almost any kind of soil, making both ornamental and desirable specimen trees for lawn or garden.

Malus angustifolia. NARROWLEAVEN CRAB. A small tree with rigid spiny branches, very beautiful and floriferous. Flowers very fragrant, pink or rose, borne in a profusion of small clusters. Fruit

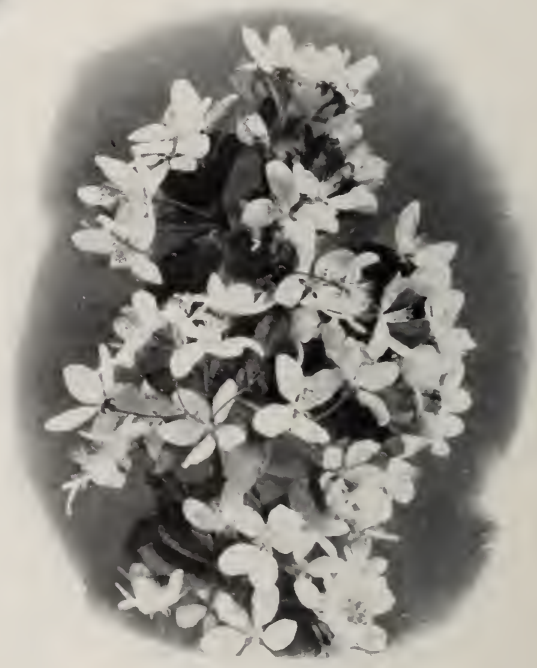

Malus spectabilis 


\section{BILTMORE, N.G. TEXYS}

\section{Malus continued}

Malus spectabilis riversi. DOUBLE-FLUWERING CHI NESE CRAB. Flowers very large, semi-double, bright rose-red. A grand flowering tree. Thrifty young plants, prepaid, $75 \mathrm{cts}$. each; larger plants, purchaser paying transporation, $75 \mathrm{cts}$. and $\$ 1.50$ each.

M. toringo. TORINGO, or DWARF CRAB. A dwarf tree with white or pinkish flowers. Very attractive in spring and literally covered with a halo of surpassing beauty. Unique. Fruit small, about the size of a pea.

Unless otherwise noted, prices of Flowering Crab-Apples, as above, thrifty young plants, prepaid, $25 \mathrm{cts}$. each; larger trees, purchaser paying transportation, 25 cts. and $50 \mathrm{cts}$. each.

SPECIAL OFFER. A collection of six Flowering Crabs, no two alike, our selection, embracing both double- and single-flowered forms, vigorous young plants, prepaid, $\$ 1.25$; larger sizes, purchaser paying transportation, $\$ 1.25$ and $\$ 2.50$.
Mohrodendron, continued

M. carolinum (Halesia tetraptera). Silver BELL. A tree with a narrow crown, blossoming profusely in early spring; the drooping flowers liberally disposed along the shoots and branches. The bright green leaves turn pale yellow in autumn, soon falling and exposing the papery seed-pods with their four-winged sides. Hardy and desirable.

M. dipterum (Halesia diptera). Sxowdrop TREE. A small tree or large shrub forming a low wide head. Needs protection from cold winds north of Philadelphia and Memphis. The flowers are borne in loose drooping clusters, and make an inspiring display of purity and grace. The persistent seed-pods have two papery wings. Very beautiful and commonly cultivated in the South.

Either of the Silver Bell Trees, vigorous young plants, prepaid 25 cts. each; larger sizes, purchaser paying transportation, $25 \mathrm{cts}$. and $50 \mathrm{cts}$. each.

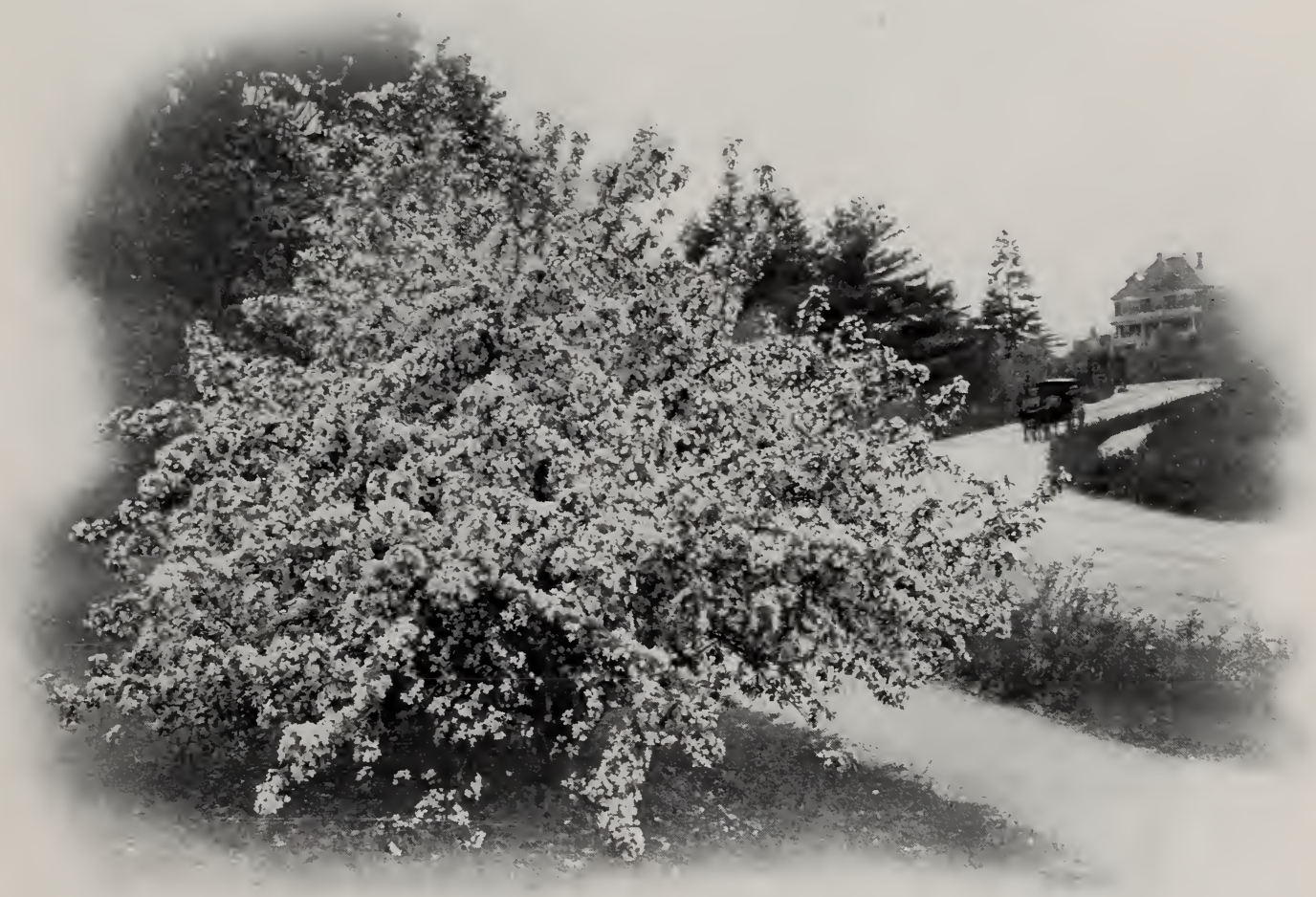

Malus floribunda (see page 32)

\section{Mohrodendron . The Silver Bell Trees}

The charm of distinctiveness never fails to awaken keen interest and admiration, but when the distinctive characters are blended with rare grace and subtle beauty, as they are in the transcendent Silver Bell trees, our enthusiasm is overflowing. The pearly white flowers, like snowdrops in their dainty outline, hang pendent in luxurious fashion from the budding branches, lending brightness, hope and cheer. Thrive best in moist loamy soil, with abundant fertility.

\section{Myrtus}

Myrtus communis. TRUE MYRTLE. This classic shrub, with handsome aromatic foliage, is extensively cultivated as a pot plant in the North, or in the open air in the South and California. The dainty white and deliciously fragrant flowers, so beautifully contrasted against the evergreen lustrous leaves, are ideal symbols of sweetness and purity. Vigorous young plants, prepaid, 25 cts. each; larger sizes, purchaser paying transportation, $25 \mathrm{cts}$. and $50 \mathrm{cts}$. each.

The plants you sent have been received in fine shape. They are fine specimens and I am well pieased with them. Yours are fine specimens and 1 am weil pieased with Spring, Tenn., Nov. 12, 1908 . 


BILTMORE NURSERY W XS

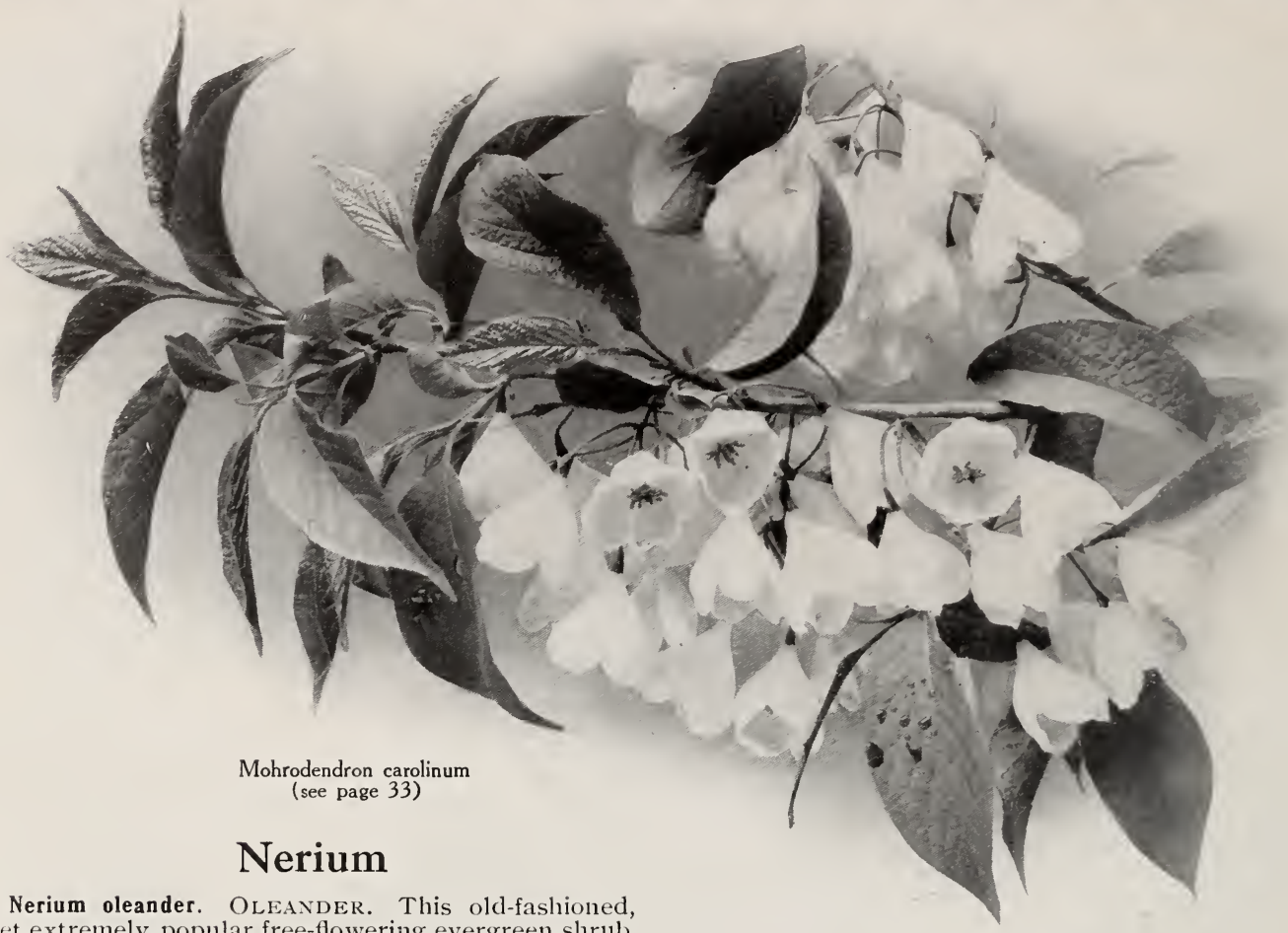

Nerium oleander. OLEANDER, This old-fashione yet extremely popular free-flowering evergreen shrub, is extensively cultivated as a house-plant in the North, and as a garden plant in the Southern States and California. The pretty and showy flowers, in both singleand double-flowered forms, range in colors from white to shades of rose and pink. They are well adapted to

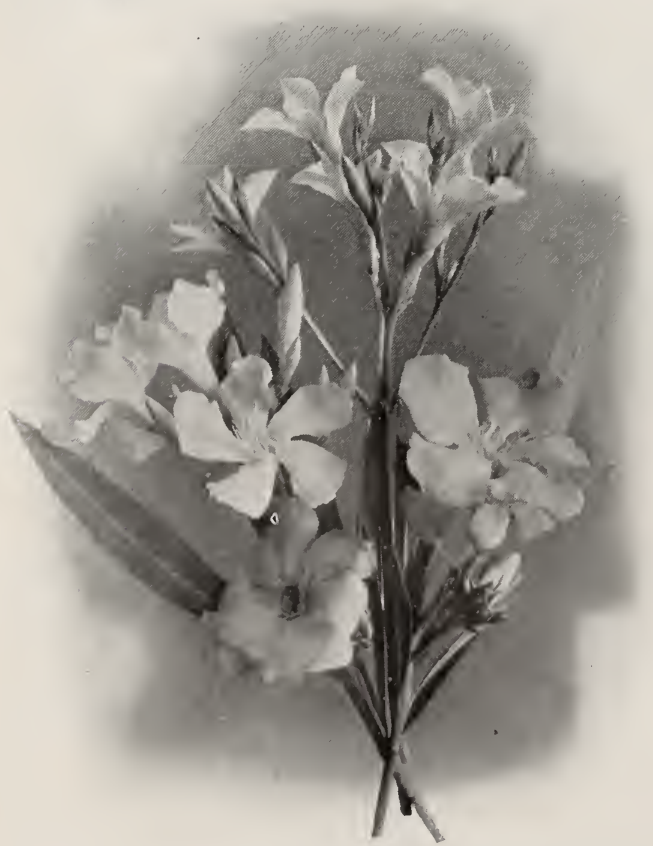

Nerium, continued

city conditions, withstanding smoke and dust without apparent detriment. Thrifty young plants, prepaid, 25 cts. each; larger shrubs, purchaser paying transportation, $25 \mathrm{cts}$. and $50 \mathrm{cts}$. each.

\section{Neviusia}

Neviusia alabamensis. SNow IVREATH. An extremely rare and fascinating shrub with slender, wand-like branches, producing a profusion of feathery blossoms. It is hardy in Missouri and Massachusetts, and thrives in almost any fertile, well-drained soil. The flowers which adorn the graceful, leafy shoots, appear like fluffy, fringe-like clusters from the long white filament. of their numerous stamens. Grows 5 to 8 feet tall. Vigorous voung plants, prepaid, $25 \mathrm{cts}$. each; larger shrubs, purchaser paying transportation, $25 \mathrm{cts}$. and $50 \mathrm{cts}$, each.

\section{Opulaster}

Opulaster opulifolius (Physocarpus opulifolius: Spirae opulifolia). NinEBARK. Both the graceful show' blossoms and the clusters of bright red seed-pods of the vigorous hardy Ninebark lend resplendent beauty to summer aspect of the garden. It makes a handsome specimen plant, when its spreading, often arching branches are well developed, and especially in early summer, when the bright green leaves contrast the dainty arrangement of the cream-white flower-clusters. Strong plants, prepaid, I5 cts. each; larger sizes, purchaser paying transportation, i5 cts. and $25 \mathrm{cts}$. each.

\section{Osmanthus . The Fragrant Olives}

In the South and in California, these handsome shrubs are desirable garden objects, both on account of their attractive evergreen foliage and the wonderful fragrance of their flowers. The Holly-leaved 


\section{Q RILTMORE, N.G. N N.2,}

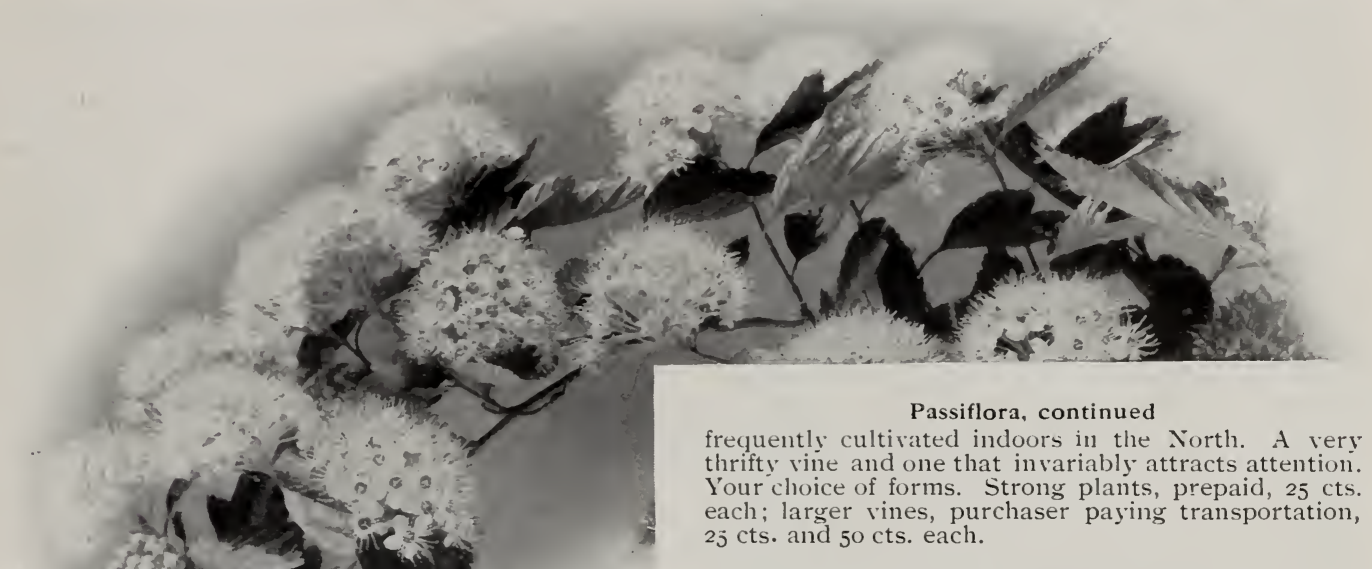

\section{Paulownia}

Paulownia imperialis. EMPRESS TREE. Reflecting its quota of the glamour of the Orient, the native home of this remarkable tree, both in spectacular display of flowers and extraordinary size of leaves, one cannot suppress an exclamation of surprise in viewing the dramatic effect of the Empress Tree. The large erect panicles of flowers of pa!e violet, indescribably beautiful, are produced in lavish profusion before the huge leaves appear. Not entirely hardy north of Massachusetts and Missouri, requiring protection from piercing winds in less favored regions. During the winter the clusters of flower buds for the ensuing year, together with the seed-pods of the past season, hang side by side, and impart a peculiar aspect. It has been successfully used as a street tree in the South, where it withstands admirably the effects of smoke and dust. Thrifty young plants, prepaid, $25 \mathrm{c}$. each; larger trees, purchaser paying transportation, 25c., 50c. and \$I each. Very attractive and the hardiest member of its genus.

0. fragrans. Fragrant Olive. A shrub with thick glossy evergreen leaves. Flowers white, in spreading clusters, exquisitely fragrant. In the North often used as a pot-plant.

Either of the Fragrant Olives, thrifty young plants, prepaid, 50 cts. each; larger sizes, purchaser paying transportation, $50 \mathrm{cts}$. and $75 \mathrm{cts}$. each.

\section{Oxydendrum}

0xydendrum arboreum. SOURwood. This beautiful tree is indeed an object of admiration, not alone for the intense and lively colors of its leaves, which glow in autumn in dazzling shades of scarlet, but for the dainty flowers, like clustered sprays of Lily-of-theValley, which terminate the slender, spreading branches of its crown in midsummer. One of the really fine ornamentals, both hardy and adaptable, thriving in sun or shade. Thrifty young plants, prepaid, 25 cts. each; larger trees, purchaser paring transportation, 25 cts., $50 \mathrm{cts}$. and $75 \mathrm{cts}$. each.

\section{Passiflora}

Passiflora caerulea. PASSION Flower. The early Spanish travelers in South America, who observed this slender but vigorous - growing vine, were deeply impressed by the strange and curious flowers which seemed to them to be srmbolic of the passion of our Lord. The fragrant blossoms, some 3 or 4 inches across, are greenish white, with a fringe-like crown, the numerous rays of which are blue at the tip, white in the middle and purple at the base. A variety known as Constance Elliott, has remarkably fragrant white flowers. Hardy in the Southern States and California, and

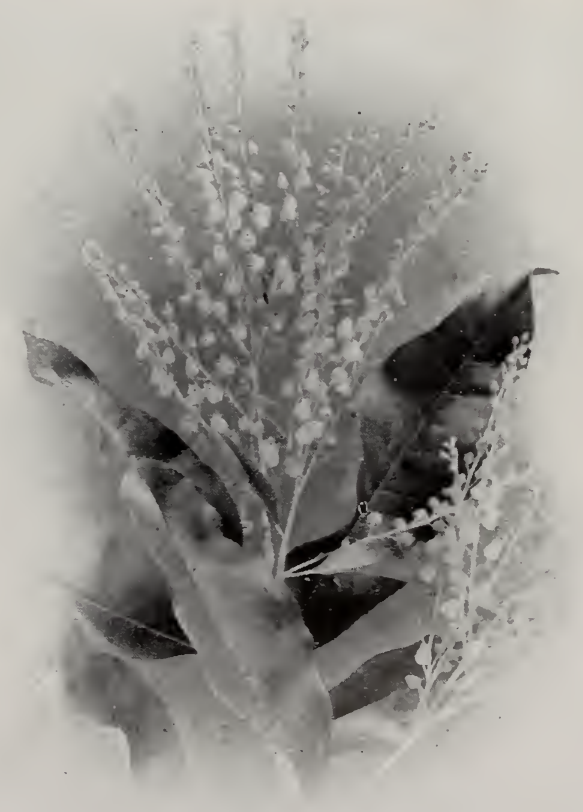

Oxydendrum arboreum 


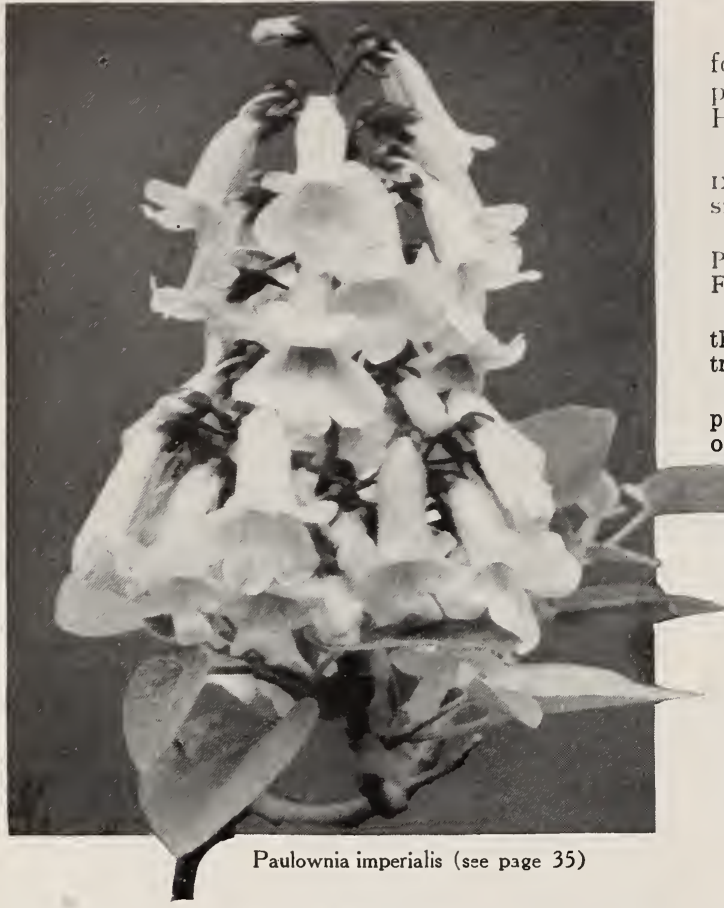

Persica, continued

for cut-flowers. Just try them; they cannot fail to please you with their bright and cheerful blossoms. Hardy wherever the Peach is cultivated.

Persica vulgaris alba plena. DOUBLE IVHITE-FLOWERING P'EACH. Double white flowers, very full, of exquisite form and substance.

P. vulgaris rosea plena. DOUBLE ROSE-FLOWERING PEACH. A splendid companion tree for the above. Flowers rose-colored, full and double. Charming.

Either of the above varieties of the Flowering Peach, thrifty young trees, prepaid, $50 \mathrm{cts}$. each; stronger trees, purchaser paying transportation, $50 \mathrm{cts}$. each.

SPECIAL OFFER. In view of the usual desire of our patrons to plant both forms, we offer one strong plant of each, prepaid, for $75 \mathrm{cts}$. ; larger trees, purchaser pay-

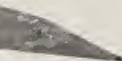
ing transportation. $75 \mathrm{cts}$

\section{Philadelphus . The Mock Oranges}

Among the grandest shrubs, those that add beauty, grace and perfume to our gardens, the Mock Oranges, or Syringas, stand high both in rank and favor. They are such glorious, hardy plants, with flowers so pure and white, and fragrance so rich and sweet, that we unhesitatingly commend them to the attention of every planter. The blossoms, profusely borne in early summer, literally cover the branches like a mantle of snow.

\section{Persica . The Flowering Peach}

Comparatively few planters are acquainted with the beautiful, double-flowered forms of the Peach, or know of their radiant and enchanting flowers, produced in such bewildering affluence during the early days of spring. Not only do they make charming garden trees, but the sprays are very valuable

Philadelphus coronarius. COMMON MOCK ORANGE. SYRINGA. A robust rapid-growing shrub with upright, often arching branches, attaining a height of 8 to Io feet. Flowers deliciously fragrant, borne in bewildering numbers transforming the branches into garlands of surpassing purity and splendor.

P. grandiflorus. LARGE-FLOWERING MOCK ORANGE. A large and gracefu! shrub with spreading, often recurved branches, producing a great wealth of blossoms

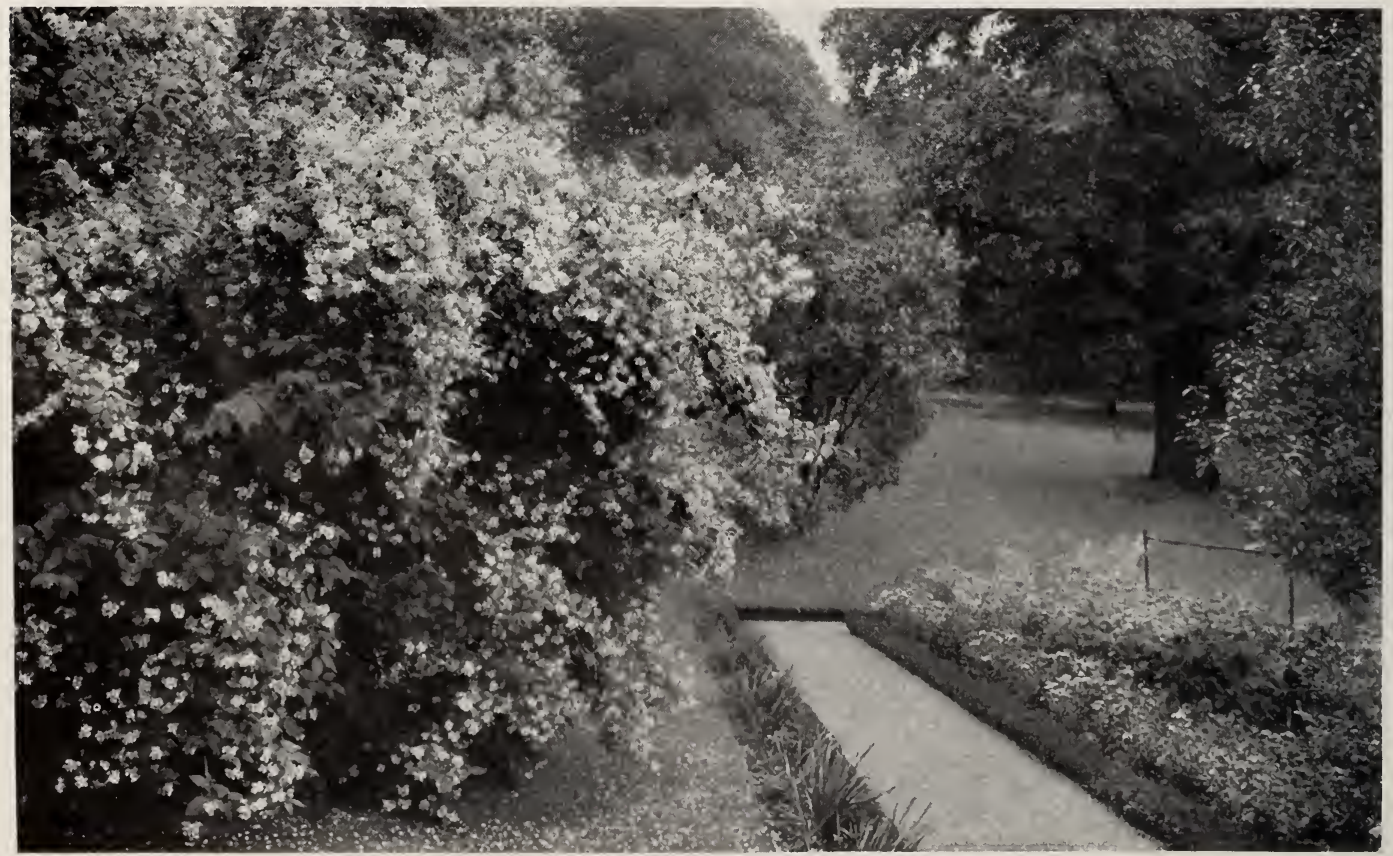

A fine plant of Philadelphus coronarius in blossom 


\section{QF Y RILTMORE. N.G. TS N.ST}

Philadelphus grandiflorus, continued

of unusual size and matchless purity. Our strain of this superb variety is renowned for vigor, large flowers and profusion.

P. latifolius. BROAD-LEAvED MOCK ORANGF. This is the tallest species of Syringa and one of the showiest. The blossoms are produced in numerous many-flowered racemes which grace the branches in such bewildering profusion that the shrub appears to be completely clothed in white. Glorious as a specimen plant.

P. lemoinei. HYBRID MOCK ORAxGe. A very showy and floriferous shrub in which the good qualities of the Syringas have been deftly blended. The graceful habit of growth and marvelous inflorescence have attracted the world-wide attention of planters, who without reserve have endorsed the excellence of this grand hardy strain. Highly recommended. Thrifty young plants, prepaid, 25 ct.s. each : larger shrubs, purchaser paying transportation, $25 \mathrm{cts}$. and $50 \mathrm{cts}$. each.

Unless otherwise noted, any of the above Mock Oranges, thrifty young plants, prepaid, 15 cts. each; larger sizes, purchaser paying transportation, 15 cts., $25 \mathrm{cts}$. and $35 \mathrm{cts}$. each.

SPECIAL OFFER. One each of the four Mock Oranges, strong plants, prepaid, 60 cts.; larger shrubs, purchaser paying transportation, 60 cts. and $\$ 1$.

\section{Pieris . The Fetter Bushes}

Awakened by the first breath of Spring, the beautiful white flowers of the Fetter Bushes expand in joyous brightness, and impart against the verdure of their winter foliage, a mystic contrast most inspiring. They are charming, dainty shrubs, with character and stamp above the ordinary. Partial shade, or situations with northern exposure, should be selected for them

Pieris floribunda (Andromeda floribunda). MounTAIN FETTER BUSH. An extremely hardy evergreen shrub, in cultivation attaining a height of 2 to 4 feet. The showy blossoms are produced in numerous clusters from the tips of the leafy twigs and branches, and adorn the plants in early spring with crowns of white. A gem for any garden. Thrifty young plants, prepaid, \$I ea. larger sizes, purchaser paying transportation, \$I and \$1.25 each.
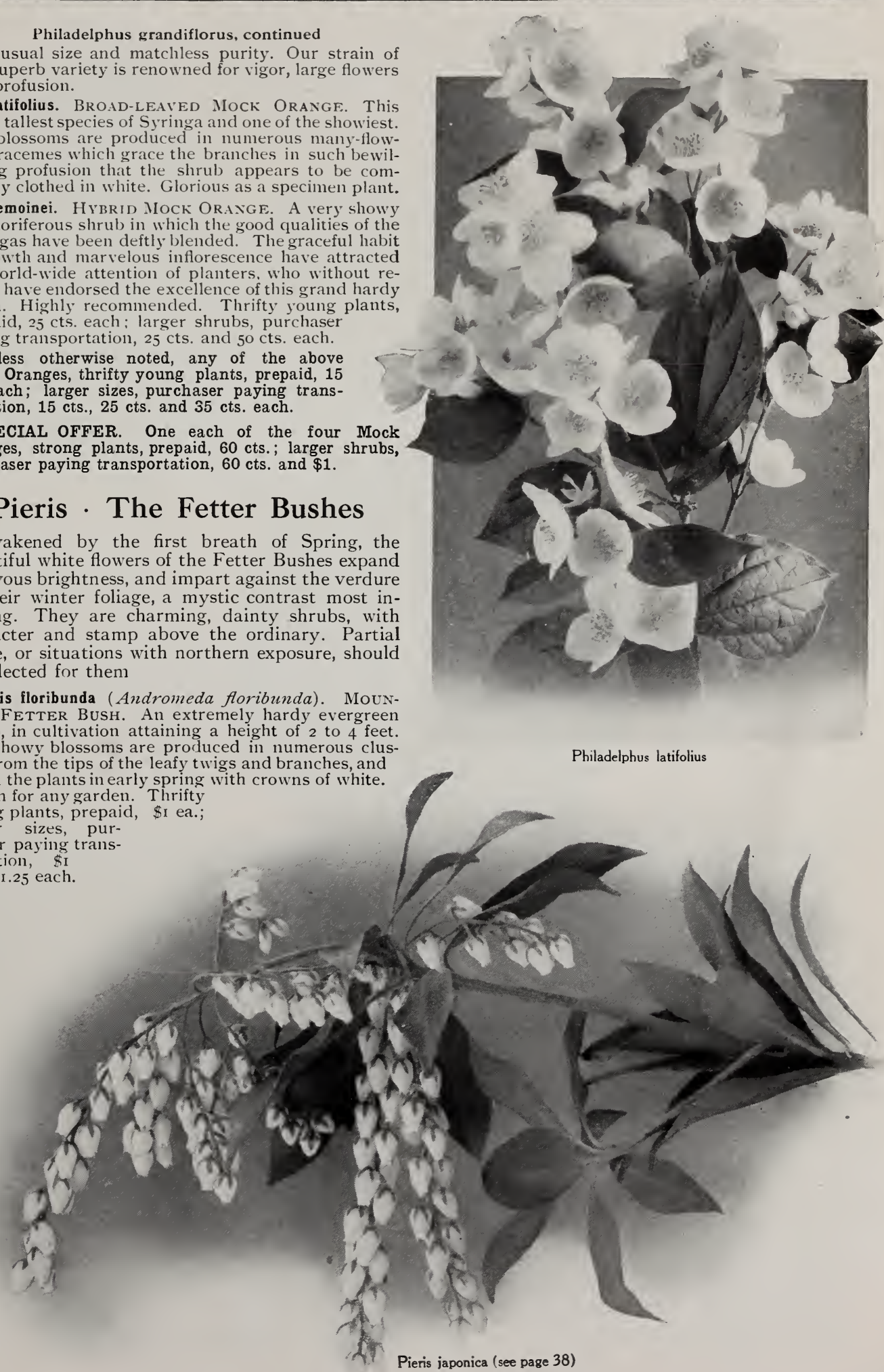

Philadelphus latifolius

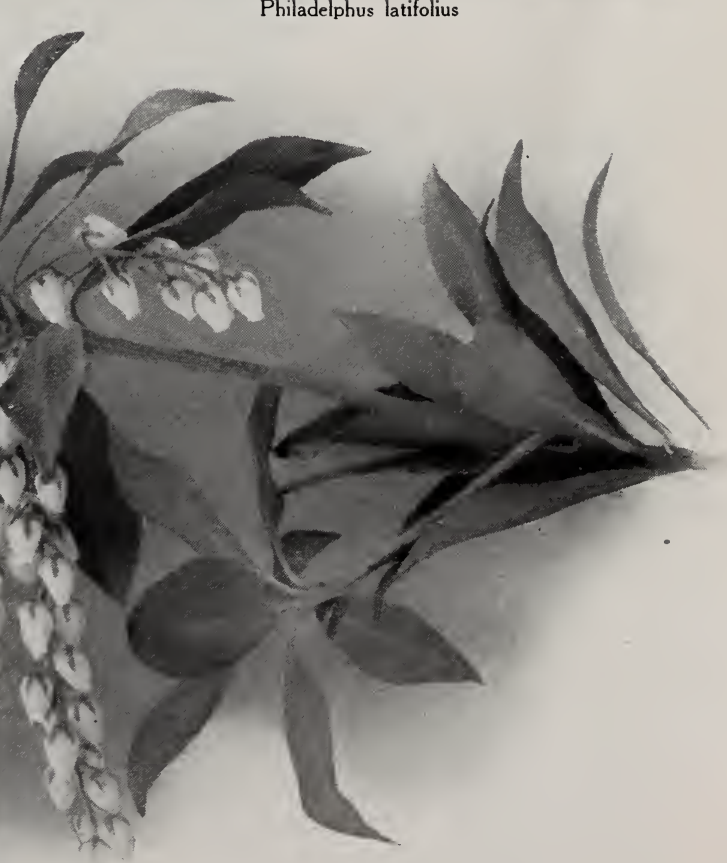

Pieris japonica (see page 38 ) 


\section{BILTMORE NURSERY ' K WE}

Pieris, continued

Pieris japonica (Andromeda japonica). JAPANese Fetter Bush. Of larger size and looser habit than the last. Leaves bright green, assuming in winter rich tones of red and bronze. Flowers in drooping clusters, pearly white, the embodiment of grace and daintiness. Hardy, with protection from cold winds, as far north as Massachusetts and Missouri. Really grand. Thrifty young plants, prepaid, $75 \mathrm{cts}$. each; larger sizes, purchaser paying transportation, 75 cts. and $\$ 1$ each.

\section{Pittosporum}

Pittosporum tobira. Tobira. Fragrant Pittosporum. A handsome evergreen shrub with very glossy foliage and dense clusters of fragrant white flowers, which change to yellow as they fade. It blossoms during the winter months and is largely planted in the South and in California in the open air, and as a house plant in the North. Makes a splendid and attractive specimen. Vigorous young plants, prepaid, $50 \mathrm{cts}$. each : larger sizes, purchaser paying transportation, $50 \mathrm{cts}$. and $75 \mathrm{cts}$. each.

\section{Populus}

Populus tremula. Aspen. The cheery message of Spring's advent, heralded by the fluffy drooping catkins of the Aspen which, like sentinels, are ever alert to give prompt warning, has no sponsor more outspoken in its gladness. These precocious flowers drape in somber but joyous raiment the leafless branches, gayly swinging in the sunshine of their hope. The inspiration one receives from the first spring flowers makes the cultivation of this hardy, fast-growing tree most desirable. Vigorous young trees, prepaid, $25 \mathrm{cts}$. each; larger trees, purchaser paying transporta tion, $25 \mathrm{c}$., $50 \mathrm{c}$. and $75 \mathrm{c}$. ea.

The shipment of trees came in first-class condition and was well pleased with them and the very moderare charge for the same-R. N. KESThRSON, Knoxville, Tenn., Apr. 20,1908 .

My plants received this morning in fine condition. I never saw allything more beautifully packed. Many thanks.-E. K. Rucker, Canton, Miss.

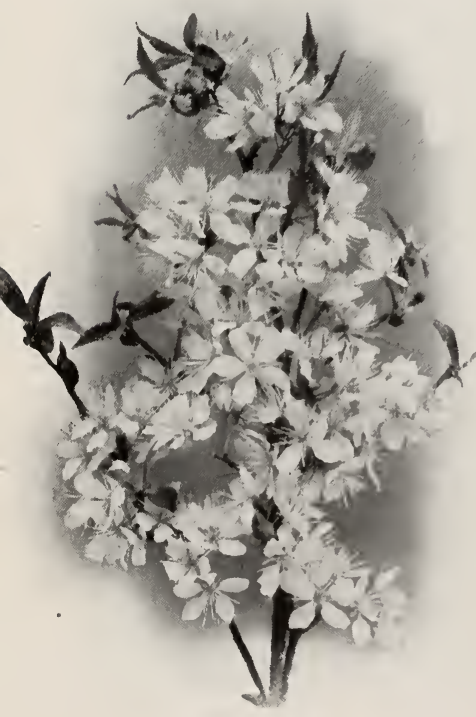

Prunus americana

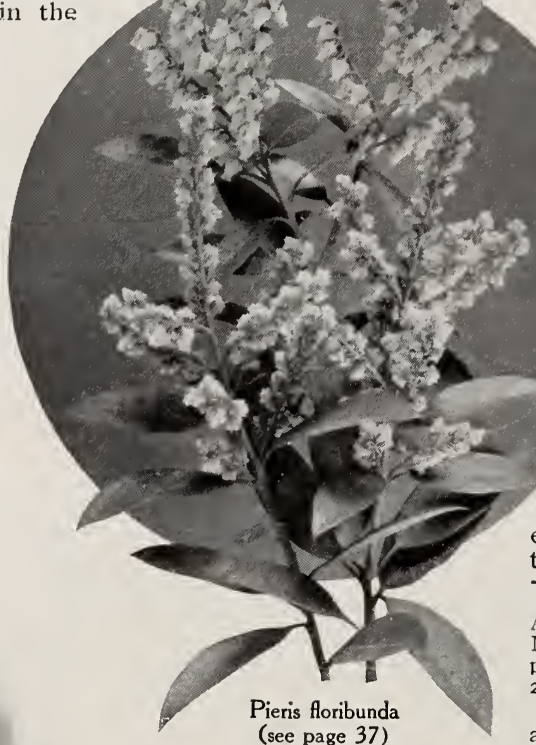

(see page 37 )

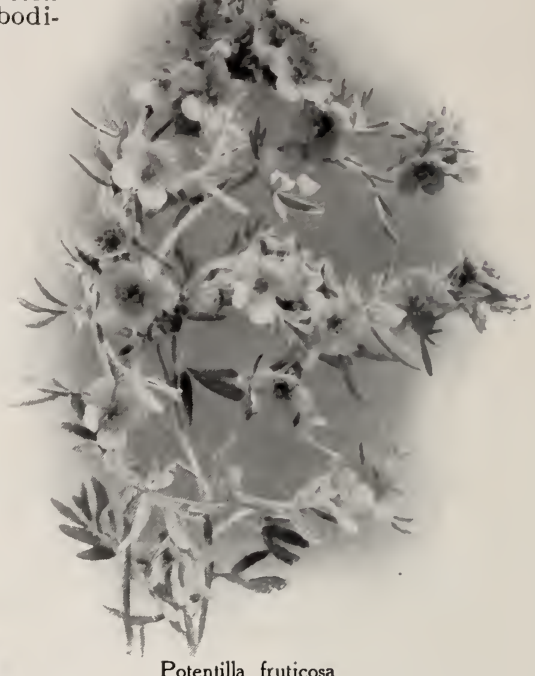

Potentilla fruticosa

\section{Potentilla}

Potentilla fruticosa. SHRLBBY Cinqueforl. Shining like stars in the firmament, the quaint and brilliant rellow blossoms of this distinct and handsome hardy shrub appear throughout the summer season. It is so refined and dainty, and expressive of brightness and good cheer, that a patron asked frankly why we did not exploit its merits with more vim. A splendid border plant, preferring sunny situations. Strong plants, prepaid, $15 \mathrm{cts}$. each; larger sizes, purchaser paying transportation, 15c., 25c. and $35 \mathrm{c}$. each.

I want to thank you for the selection of Arborvitæs you sent me in answer to my order No 45 . They are very ornamental and I am pleased with them.-Mrs. ROBT. C. Rogers, 217 N. Limestone Si., Springfield, O., May 2.

The Roses ordered some days ago have arrived and are doing fine-E. W. PARKER, Columbia, S. C., Apr. 8,1908 .

\section{Prunus . The Flowering Plums, Dwarf Almond and Sand Cherry}

Beaming with brightness and radiancy of beauty, the members of this little group of spring-flowering trees and shrubs transform our cheerless gardens, as sunshine lights our lives. Their hardiness and earliness commend them, but the crowning glory is the profuse display of showy flowers - the delight of humming bees and fairy butterflies.

Prunus americana. WILD PLUM. A small tree with a broad and intricately branched crown. The myriads of white flowers clothe the leafless branches like a canopy of snow. Very showy when in tlower, and clesirable in border planting.

P. japonica (P. nana and P. sinensis; Amvgdalus pumila). Dwarf, or FLOWERING ALMOND. One of the best of flowering shrubs, attaining a height of about 3 feet. Flowers very full and double, densely clustered along the shoots and branches. There are two forms, white and rose, each of strpassing beauty. Old and well-tried favorites.

P. maritima. BEACH Plum. A decumbent, ustially spiny shrub, producing a wealth of white flowers before the leaves appear. A gem for the rock-garden. 


\section{Prunus, continued}

Prunus pissardi. PURPLE-LEAVED PLUM. A handsome small tree with purple foliage, very hardy and the best of purple-leaved trees, enduring the hot stin without injury to the leaves. The blush-pink flowers are borne in great profusion, and harmonize with the color tone of the unfolding leaves. Splendid for specimen planting.

P. pumila. SAND ChERRY. Shrubby, the upright branches from 3 to 5 feet tall. The white flowers appear in numerous small clusters before the unfolding of the leaves. The foliage fades in autumn with brilliant colors.

P. triloba. FLOWERING Plum. A small shrub with downy, often 3 -lobed leaves. Flowers double, pink or rosecolor, appearing just before the leaves unfold, very profuse and showy. A favorite.

Any of the Flowering Plums and Dwarf Almonds, vigorous young plants, prepaid, 25 cts. each; larger sizes, purchaser paying transportation, 25 cts., $35 \mathrm{cts}$. and $50 \mathrm{cts}$. each.

SPECIAL OFFER. A collection of four of the above, no two alike, our selection of varieties, embracing some of the best forms, thrifty young plants, prepaid, 85 cts. ; larger sizes, purchaser paying transportation, 85 cts. and $\$ 1.25$.

\section{Pterostyrax}

Pterostyrax hispida (Halesia hispida). JAPANESE SILVER BELl. A rare and handsome small tree, closely related to the Silver Bell. In the Middle and Southern States, where it is hardy, it is justly prized for its wealth of showy blossoms. Flowers fragrant, creamy white, resembling the Deutzias, borne in drooping panicles in early summer. Strong plants, prepaid, 50 cts. each ; larger shrubs, purchaser paying transportation, 5o cts. and \$I each.

\section{Rhododendron - The Rose Bay and Laurels}

It is the ambition of every planter to successiully cultivate the glorious Rhododendrons-the show iest of all ornamentals. And they are justly popular, for their handsome evergreen foliage and superb flowers make possible some of the most enchanting results, giving zest and interest that cannot be obtained with other plants. They thrive in porous, fertile soils, preferring a northern exposure with partial shade. When in the open, it is advisable to shelter the plantations against drying winds and hot sun by a belt of tall coniferous evergreens. After planting, the surface of the ground should be liberally covered with forest leaves or pine needles to protect the roots from sudden changes of temperature. The dwarf varieties are more effective when planted by themselves, as their smaller leaves and Howers do not harmonize with those of larger varieties. The Great Laurel is the largest and hardiest, while the Catawba Rhododendron ranks second; a happy crincidence in parity with value.

Rhododendron arbutifolium ( $R$. wilsonianum). DWARF RHODODENDRON. A beautiful dwarf shrub of compact habit. Leaves 2 to 3 inches long, dark green, densely clothing the short branches. Flowers pink, or very light rose, freely produced in early summer. This variety is very hardy and is one of the best of the dwarf sorts. Splendid for a rockery.

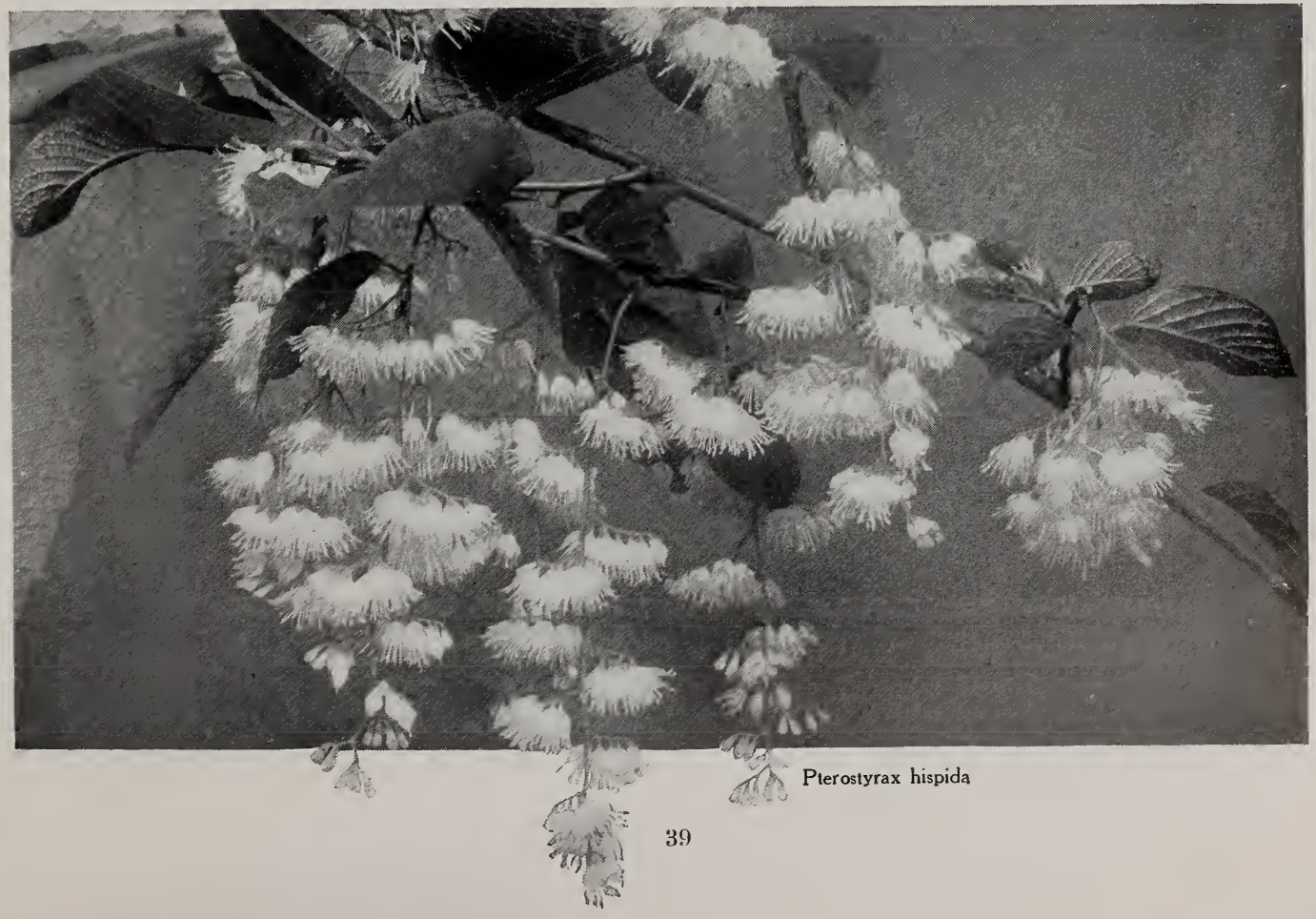




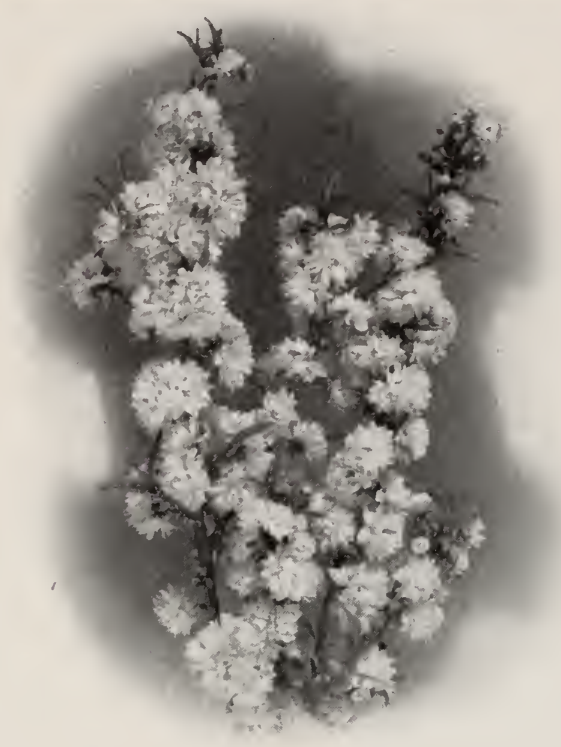

Prunus japonica (see page 38 )

Rhododendron, continued

Rhododendron catawbiense. CATAWBA RHODODENDRON. A magnificent hardy flowering shrub, portraying the highest type of beauty. The large bright green leaves are clustered at the ends of the branches, and form a fitting background against which the majestic clusters of transcendent rose-purple flowers are contrasted in sublime splendor.

\section{Rhododendron, continued}

Rhododendron catawbiense hybridum. CATAWBA HYBRID RHODUDENDRON. Glorious, hardy shrubs, in which the good traits of several races have been deftlyblended, the flowers displaying a great diversity of colors, ranging from white to pink, rose, red, crimson and purple. They embrace all of the attractions of the Catawba Rhododendron, with wonderful color effects thrown in. Your choice of colors. Thrifty young plants, prepaid, \$I each: larger sizes, purchaser paying transportation, \$1, \$1.50, \$2 and $\$ 2.50$ each.

R. maximum. ROSE BAY. GREAT LAUREL. This noble shrub, the grandest of the Rhododendrons and seemingly near the climax of Nature's achievement. is magnificent beyond comparison. The beautiful large leaves, varying from 6 to 10 inches in length, clothe the graceful branches with a mantle of clark rich green, the luxuriance of which is simply regal. In early summer the profuse large clusters of pinkish white flowers, gleaming brightly in the richness of their setting, transform the aspect to one of radiant beauty.

R. myrtifolium. IYrTLE-LEAVED RHODODENDRON A low dense shrub of great hardiness and bealuty: Leaves dark green, assuming in winter rich shades of bronze and ruddy green. Flowers pink or rose color, very profuse. A charming plant.

R. punctatum. SIIALL, OR EARLY-FLOWERING RHODODENDRON. This is the earliest-flowering species, and particularly valuable on this account. Leaves dark green, dotted beneath. Flowers in spring, pale rose, spotted with yellow-green within. Very pretty.

Except where noted, the price of the above Rhododendrons, thrifty young plants, prepaid, $\$ 1$ each ; larger plants, purchaser paying transportation, $\$ 1, \$ 1.25$ and $\$ 1.50$ each.

SPECIAL OFFER. One plant each of the above varieties including one Catawba Hybrid Rhododendron, six plants in all, vigorous young stock, prepaid, $\$ 5$. larger plants, purchaser paying transportation, $\$ 5$ and $\$ 6.50$.

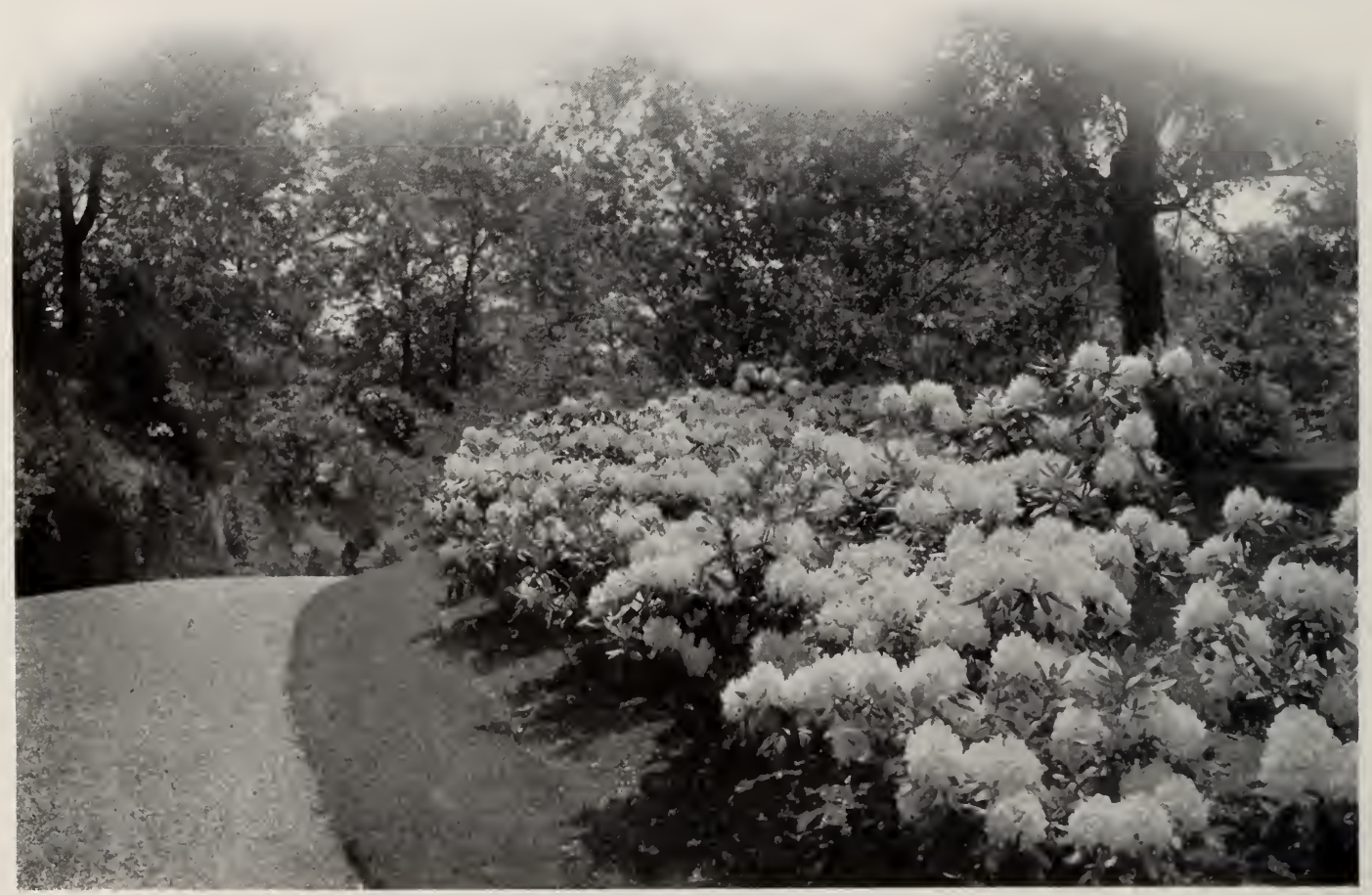

Observe the splendor of a Rhododendron planting 

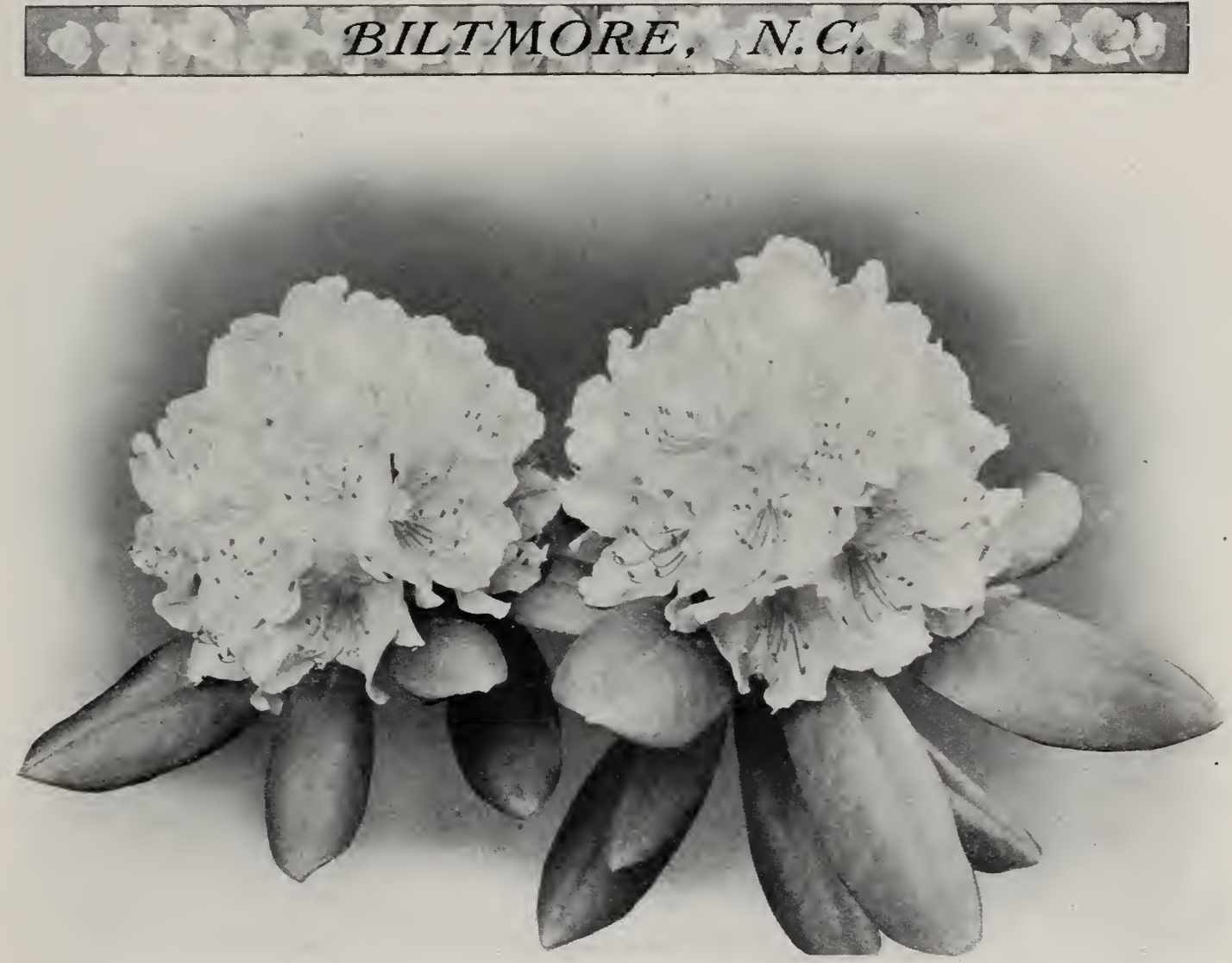

Catawba Hybrid Rhododendron (see page 40)

\section{Rhodotypus}

Rhodotypus kerrioides. WHHTE KERRIA. With green and lustrous plaited leaves, pure white and ample flowers, and seeds of shining black like jewels in their sun-burst settings, the glorious white Kerria in gay attire is nothing if not distinctive and refined. A hardy, thrifty shrub, usually 4 to 5 feet tall-one that will surely attract attention. Strong plants, prepaid, I5 cts. each; larger shrubs, purchaser paying transportation, 15 cts., 25 cts. and 35 cts. each.

\section{Ribes - The Flowering Currants}

Impatient of delay in Spring's advent, the precocious blossoms of the Flowering Currants await only a prelude to unfold in pendulous clusters their bright colors and spicy fragrance. They are attractive and showy objects of extreme hardiness and adaptability, and worthy of universal culture.

Ribes aureum. Missouri, or Flowering CurRant. A vigorous shrub with upright branches, eventually 5 to 8 feet tall. Flowers yellow, large and showy, produced in numerous leafy-bracted clusters in early spring, attracting noisy bees and gaudy butterflies like the fabled fairy garden. The dark brown or jetblack berries are edible. A splendid shrub.

R. sanguineum. RED-FLOWERED CURRANT. A large shrub of upright habit with many red-barked twigs. Blossoms rose-red or ruddy purple in long drooping racemes in early spring. Berries bluish black with gland-tipped hairs. Very ornamental and a splendid companion plant for the preceding kind.

Either of the Flowering Currants, strong plants, prepaid, 25 cts. each; larger sizes, purchaser paying transportation, $25 \mathrm{cts}$. and $35 \mathrm{cts}$. each

\section{Robinia - The Locusts and Rose Acacia}

The sweet fragrance of the Locust blossoms, drifting with the air currents of a tranquil day toward the end of spring, is a sensation never to be forgotten, so delightful and seductive is the charm.

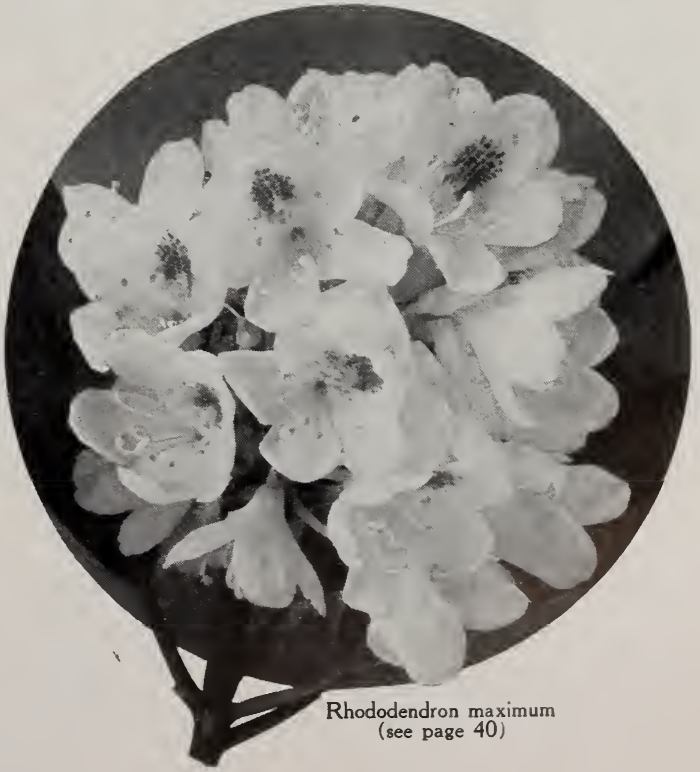




\section{BILTMORE NURSERY}

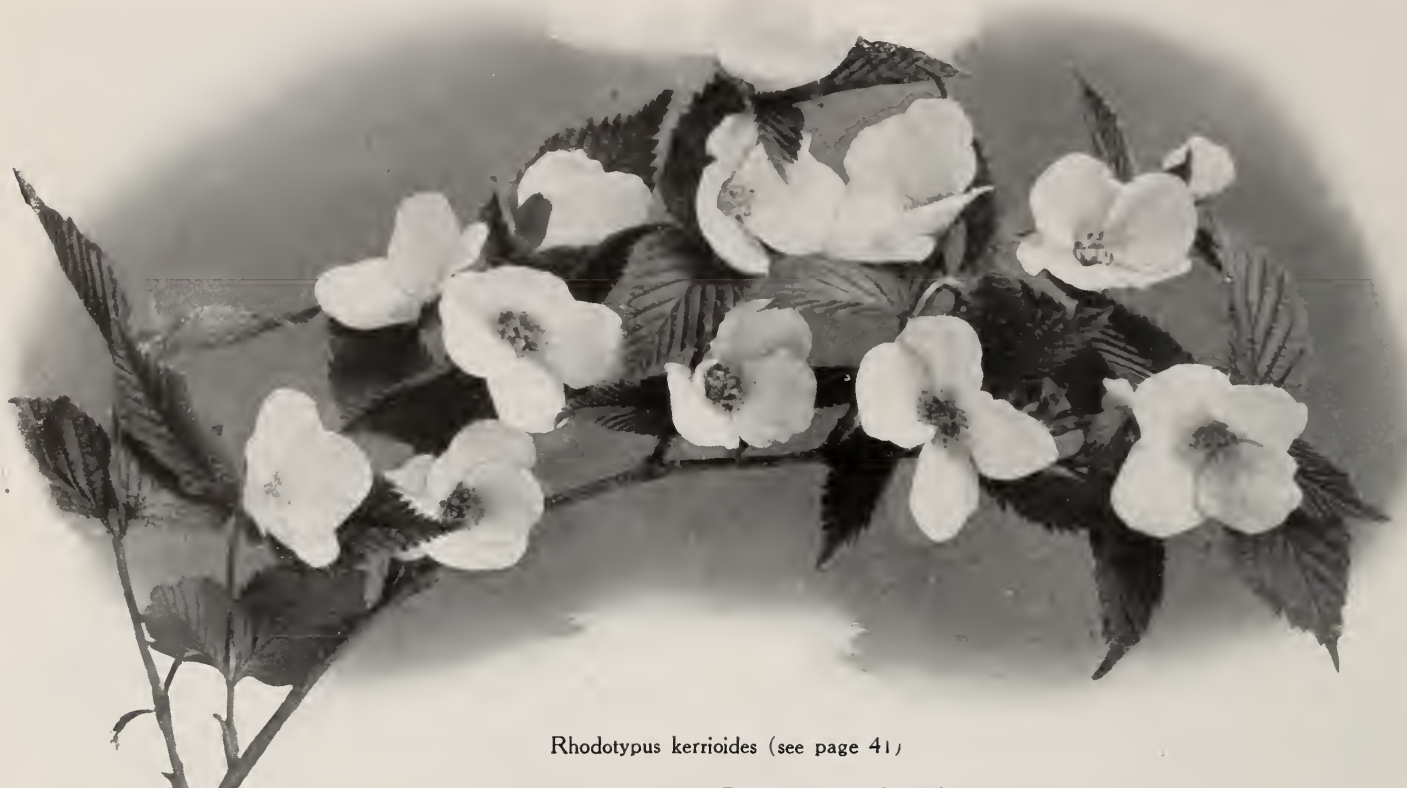

Robinia, continued

A perfume rich and sweet and pure from hosts of showy flowers drooping in grapelike clusters from the leafy branches. Graceful in outline, feathery in foliage, handsome in flower, hardy and rapid in growth, they embody many attributes of merit and adornment. They thrive best in light, well-drained soils.

Robinia hispida. Rose ACACIA. A small shrub, usually 2 to 3 feet tall, the branches more or less bristly-hairy: Flowers rose-color, very showy, in loose nodding racemes. Splendid for a rock-garden.

R. pseudacacia. Black Locust. A beautiful specimen tree for the lawn and one that is widely planted as an ornamental. The profuse clusters of white flowers are extremely pretty and effective. Well adapted to sunny situations.

R. viscosa. Claniry Locust, A small tree with viscid, clammy twigs. The flowers are very handsome, pale rose, borne in dense glandular racemes. Try this interesting, attractive subject-its beauty will impress you deeply.

Any of the Robinias, thrifty, young plants, prepaid, 25 cts. each; larger sizes, purchaser paying transportation, $25 \mathrm{cts}$. $35 \mathrm{cts}$, and $50 \mathrm{cts}$, each.

\section{Rubus}

Rubus odoratus. FlowerING RASPBERRY. Blossoming for weeks during late spring and summer, the large and showy rosy purple flowers of this hardy and remarkably attractive plant make a prolonged and pleasing display. It is a vigorous upright shrub with numerous spineless branches and large lobed leaves resembling those of the Maple in outline. Grows 3 to 5 feet tall. Really fine. Strong plants, prepaid, I5c. each larger shrubs, purchaser paying transportation, $15 \mathrm{cts}$, and 25 cts. each.

The plants of order No. 349 were received in fine condition. I wish to thank you for sending such nice ones. They were much better than I expected to secure by mail. I wish also to thank you for the extra plant I am arreatly pleased to have it.-MRS. H. N. Ponv, Topeka, Kail., April 7, 1908 .
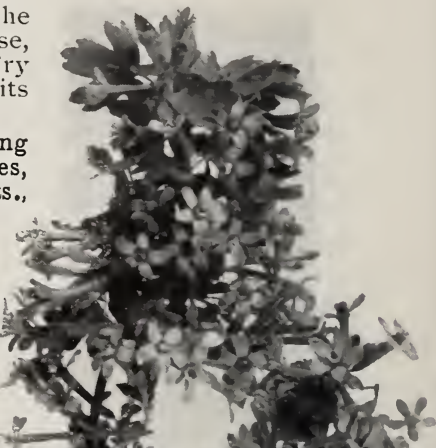

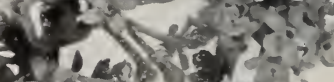

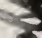
1. $2 x+\frac{1}{2} \div 2$
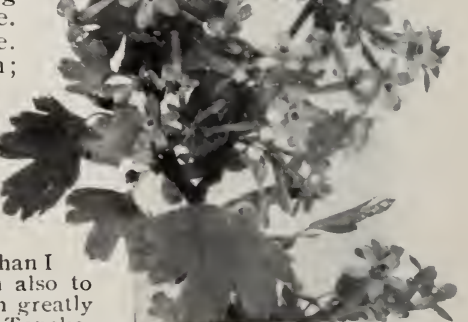

Ribes aureum (see page 41) 


\section{Q BILTMORE, N.C. TI. T.2S}

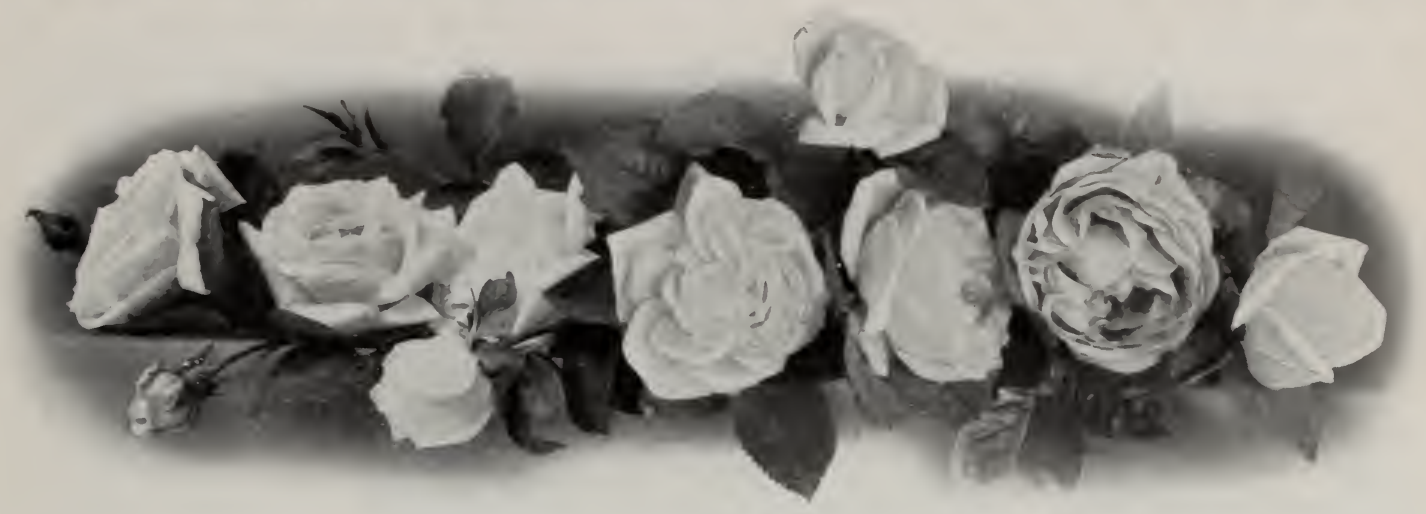

\section{Rosa . The Roses}

The Rose, the Queen of Flowers, with blossoms richly robed in satin and fragrant with attar interposed between each dainty petal, no rival can surpass. Nature in supreme achievement has prepared in many matchless forms and colors the flowers that are, and will be for ages ret to come, among the choicest treasures of our gardens. No wonder, then, the gardening impulse so often finds expression in cultivating the Rose-the flower of all the flowers that has moved and thrilled the human race for centuries.

THE Rose-the mere name an inspiration to garden lovers-so fortunately and generously favored in versatility, is adaptable to almost every requirement by selection from the numerous species and limitless garden forms. Thriving in a wide range of soils, but amply repaying any effort made to afford fertile and congenial surroundings, all varieties, for convenience, are classed in special groups, where mention is made of other conditions or treatment that may influence or safeguard successful growth and culture.

Concerming Biltyore Roses. The superb Roses which we offer are strong, vigorous plants two and three years old, all of them once or twice transplanted. They are grown with painstaking care and consideration, in order to prepare them for safe handling and the adaptation they must assume under the varying conditions of many homes. Those who have experimented with tinv plants from greenhouse benches and reaped little in success or much in disappointment, will find in thrifty Biltmore Roses enduring strength and hardiness-the birthright imparted by our mountain air.

\section{The Wild Roses, or Rose Species}

Hardy, vigorous-growing shrubs or climbers that require very little attention or pruning. They are very valuable for planting in the shrub borders, producing showy, single flowers in great profusion, together with a wealth of bright-colored fruits that prolong the period of beauty throughout the season, and, in instances, well into the winter months. The climbing species are well adapted for covering trellises, fences and similar supports, or they may be permitted to assume informal outlines by the unrestricted development of their branches.

Rosa alba. White Rose. An upright shrub with prickly branches, of uncertain ortgin. This is the single form of the Old White Cottage Garden Rose, with the beautiful fragrant white flowers which are used for the manufacture of "Attar of Roses." Very showy throughout the winter on account of the wealth of bright scarlet fruits. Height + to 6 feet. The delightful perfume of this Rose and its derivatives is renowned. Vigorous young plants, prepaid, 25 cts. each; larger sizes, purchaser paying transportation, $25 \mathrm{cts}$. and $50 \mathrm{cts}$. each.

R. alpina: AlpINe Rose. A handsome free-flowering shrub, with slender, upright branches 2 to 3 feet high. Flowers bright rose or pink, 2 inches across. Fruit nodding, bright scarlet, very showy. Splendid for rockeries. Thrifty roung plants, prepaid, 25 cts. each ; larger sizes, purchaser paying transportation, $25 \mathrm{cts}$. and $50 \mathrm{cts}$. each.

R. arvensis ( $R$. repens). EtropeAx RUXyixg ROSE. A creeping shrub with long slender stems. Flowers white, about 2 inches across, produced in numerous clusters in early summer. A very" pleasing groundcover. Strong plants, prepaid, 25 cts. each; larger
Rosa arvensis, continued

sizes, purchaser paying transportation, $25 \mathrm{cts}$. and 50 cts. each.

R. blanda. MEADow Rose. An erect shrub, 3 to 5 feet tall, with reddish purple, often ylaucous branches, armed with slender prickles. Leaves dull or bluish green. Flowers pink, large and showy. Fruit red, with a bloom.

R. bracteata. MACARTNEY Rose. A handsome climbing shrub with glossy bright green foliage and stout and very thorny stems. Flowers very large, pure white, with numerous golden yellow stamens. Not hardy north of Memphis and Washington. Nearly evergreen in the Southern and Pacific States, where it is freely planted. Thrifty roung plants, prepaid, $25 \mathrm{cts}$. each; larger sizes, purchaser paying transportation, $25 \mathrm{cts}$. and 50 cts. each.

R. carolina. CAROLINA Rose. An upright shrub with numerous spiny branches. Flowers pink, in flat-topped clusters in summer. Fruit red, profuse and showr. Splendid for massing and for waterside planting.

R. gallica. PROVExce Rose. A low upright shrub, usually 2 to 3 feet tall, with dark green leaves. Flowers pink, very large and showy; individual flowers often 2 to 3 inches across. Fruit brick-red, persisting until late fall. One of the grandest single Roses in cultivation. Vigorous roung plants, prepaid, $25 \mathrm{cts}$. each: larger sizes, purchaser paying transportation. 25 cts. and 50 cts. each.

R. humilis. LOW, OR PASTURE ROSE. An upright shrub, 2 to 3 feet high, with numerous prickly branches. Flowers pink, in early summer. A capital little plant for massing or ground-cover.

My first order was received in fine condition, and the plants are standing up nicely. Yours very truly. EDw. D. STEvexs, 629 IV. North Ave., Baltimore, Md., Misy I5, I908. 


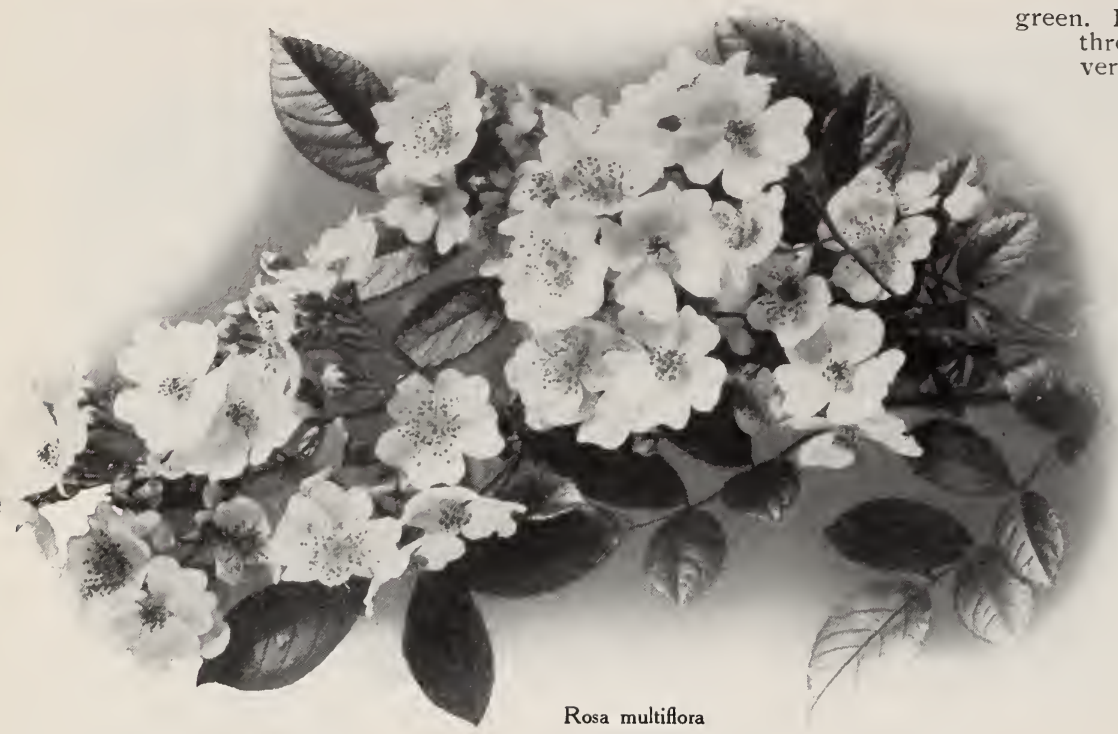

Rosa rugosa, continued

Flowers purple or white, three inches or more across, very showy. Fruits bright red, very large and effective. A grand Rose.

R. setigera. PRAIRIE RuSE. A liandsome shrub with long and slender recurved or climbing branches. Flowers deep rose, produced in great profusion in many-flowered clusters in early summer. Fruits bright red, long persistent Very ornamental. One of the hardiest Roses.

R. spinosissima. SCOTCH ROSE. A low shrub with upright and densely prickly branches. Flowers very numerous a long the branches, pink, white or creamy white, about 2 inches across. Fruit black. A re-

Wild Roses, continued

Rosa laevigata. Cheroke rose. A climbing shrub with slender prickly branches. Leaves dark green and shining. Flowers white, 2 to 3 inches across, fragrant and very showy. Not hardy in the North. Vigorous young plants, prepaid, $25 \mathrm{cts}$. each; larger sizes, purchaser paying transportation, $25 \mathrm{cts}$. and $50 \mathrm{cts}$. each.

R. multiflora. JAPANESE Climbing Rose. A vigorous shrub with long, recurved or climbing branches. Leaves bright green and lustrous. Flowers white, borne in great profusion in pyramidal clusters, covering almost the entire length of the arching branches. Handsome and showy.

R. rubiginosa. Eglantine, or Sweet Brier. An upright shrub, with numerous prickly branches. Leaves bright green, emitting an agreeable aromatic odor when bruised. Flowers bright pink, on mossy pedicels. Fruit orange-red or scarlet.

R. rubrifolia. RED-LEAvED ROSE. An upright shrub with slender purplish branches, covered with a glaucous bloom. Leaves blue-green, deeply tinged with purplish red. Flowers pink, an inch and a half in diameter. Fruit scarlet. A remarkable plant. Vigorous young plants, prepaid, $25 \mathrm{cts}$. each : larger sizes, purchaser paying transportation, $25 \mathrm{c}$. and $50 \mathrm{c}$. each.

R. rugosa. Wrinkled JAPANEsE Rose. An upright shrub with spreading branches, densely beset with spines and prickles. Leaves wrinkled, dark lustrous markably attractive and hardy shrub. Thrifty plants, prepaid, 25 cts. each ; larger shrubs, purchaser paying transportation, $25 \mathrm{cts}$. and $50 \mathrm{cts}$. each.

R. watsoni. WATSON's Rose. A curious Rose of unknown origin, with numerous arching branches. Height 2 to 3 feet. Flowers small, white, in denseflowered pyramidal corymbs. Makes an attractive low hedge for a rose-garden. Strong plants, prepaid, $25 \mathrm{c}$. each; larger sizes, purchaser paying transportation, $25 \mathrm{cts}$. and $50 \mathrm{cts}$. each.

R. wichuraiana. MEMorial Rose. A hardy half-evergreen shrub with long and slender creeping branches. Leaves dark green and shining. Flowers pure white, fragrant, about 2 inches across, borne in many-flowered pyramidal clusters. A handsome and desirable Rose for covering banks and rockeries or for training on fences and trellises.

Unless otherwise noted, any of the above Roses, thrifty young plants, prepaid, 15 cts. each; larger sizes, purchaser paying transportation, $15 \mathrm{cts}$. and $25 \mathrm{c}$. each.

I take this occasion to thank you very much for your generous treatment, quite as much as for the excellence of the stock. and the admirable manner in which they are packed. Very truly yours, J. H. WRight, Meridian, Miss., May 18,1908 .

Permit us to say that we are greatly pleased incleed with the good strong stock shipped and also the manner in which same good packed. In fact, altogether we wish to express our satis faction faction in placing this order with your. Yons truly, H. H. Decatur, Ill., Oct. 26, 1908 .'

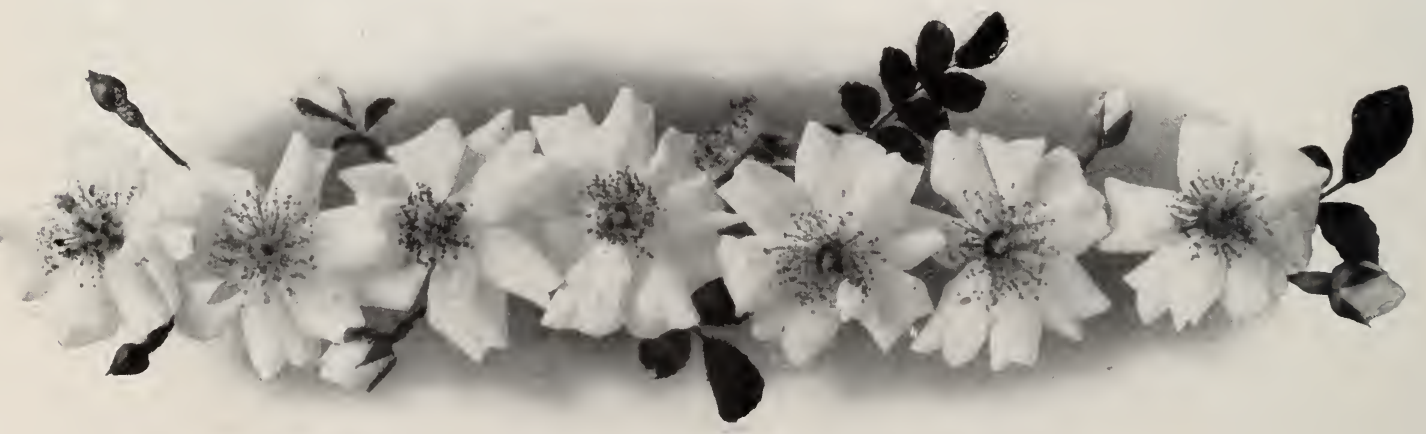

Rosa Wichuraiana 


\section{Bourbon Roses}

Very floriferous, compact shrubs, with bright, glossy foliage. The flowers are most profuse in late summer and autumn, and are noted for their exquisite form and color. They require close pruning in early spring.

Appolline. Rosy pink; flowers large and cupped. One of the best varieties.

Champion of the World. Deep rosy pink, large and double, very fragrant. A vigorous, free-flowering variety, valuable for bedding.

Hermosa. Bright rose, very double and fragrant; a constant bloomer. A universal favorite.

Souv. de la Malmaison. Delicate flesh, tinted with fawn; large and very double, deliciously fragrant. A grand Rose.

Any of the Bourbon Roses, vigorous, thrifty young plants, prepaid, 30 cts. each; larger size, purchaser paying transportation, 30 cts. each.

SPECIAL OFFER. A set of three Bourbon Roses, our selection of varieties, no two alike, thrifty plants, prepaid, 75 cts.; stronger plants, purchaser paying transportation, 75 cts.

\section{Brier Roses}

Handsome flowering shrubs, perhaps more useful as garden plants than for cut-flowers. They require very little in the way of pruning, and the shoots should be shortened only a few inches. If severely trimmed, they will not blossom until another season's growth has been produced. It is common practice to grow several plants, severely pruning a part of them in alternate years.

Austrian Copper. Flowers single, bright coppery red, the reverse of the petals golden yellow. Very effective.

Austrian Yellow. Flowers single, bright golden yellow. Handsome and showy.

Harrison's Yellow. Golden yellow semidouble flowers. Very free-flowering.

Persian Yellow. Bright yellow, nearly double flowers of exquisite form. An oldtime favorite.

Any of the Brier Roses, vigorous young plants, prepaid, 35 cts. each; stronger plants, purchaser paying transportation, 35 cts. each.

SPECIAL OFFER. A collection of three Brier Roses, no two alike, our selection, vigorous stock, prepaid, 85 cts.; stronger plants, purchaser paying transportation, $85 \mathrm{cts}$.

\section{Lord Penzance Sweet Briers}

Beautiful and interesting hybrids between the Common Sweet Brier and other Roses. The foliage is deliciously fragrant when bruised. The flowers are single and of exquisite tones of color. Very valuable for specimen plants or hedges. The following are desirable varieties:

Amy Robsart. Bright satiny rose.

Anne of Geierstein. Dark velvety crimson.

Brenda. Blush, or peach-color.

Catherine Seyton. Soft rosy pink.
Lord Penzance Sweet Briers, continued

Flora McIvor. Pure white, flushed with rose.

Lady Penzance. Soft copper, shaded with rose.

Lord Penzance. Fawn and lemon-color.

Lucy Ashton. White with pink edges.

Meg Merrilies. Rosy crimson.

Rose Bradwardine. Beautiful clear rose.

Any of the Lord Penzance Sweet Briers, thrifty plants, prepaid, $40 \mathrm{cts}$. each; stronger plants, purchaser paying transportation, $40 \mathrm{cts}$. each.

SPECIAL OFFER. A collection of six Lord Penzance Sweet Brier Roses, our selection, no two alike, vigorous plants, prepaid, $\$ 2$; stronger plants, purchaser paying transportation, $\$ 2$. Half sets, in either instance, as offered above, $\$ 1$.

\section{Climbing Tea and Noisette Roses}

Free-flowering climbing Roses with an almost continuous succession of handsome, fragrant flowers. They are especially valuable for trailing over porches, pillars or other supports, and require very little pruning. They are partial to fertile, moist soils, with a sunny exposure, and it is recommended that so far as possible, positions should be chosen that are protected from the collest winds.

Climbing Clothilde Soupert. White shaded with silvery rose. Flowers throughout the summer. Very hardy. A favorite 


\section{BILTMORE NURSERY N WQ}

Climbing Tea and Noisette Roses, continued in many localities. Strong thrifty plants, prepaid, 35 cts. each; larger size, purchaser paying transportation, 35 cts. each.

Climbing Wootton. Deep crimson; richly perfumed. Flowers large and double, blossoming throughout the summer. Vigorous plants, prepaid, 35 cts. each: larger size, purchaser paying transportation, $35 \mathrm{cts}$. each.

Gloire de Dijon. Creamy white with a blush tint, large and very double. Needs protection in the North.

Keystone. Deep lemon-yellow; flowers double, of exquisite form and fragrance. Relatively hardy and blossoms with remarkable freedom. IVe commend this Rose to the attention of planters. Thrifty plants, prepaid, 35 cts. each; larger size, purchaser paying transportation, 35 cts. each.

Lamarque. Pure white with a lemon-yellow center beautiful large buds; flowers very double and sweet. Hardy in the Southern and Pacific States.

Marechal Niel. Golden yellow; flowers large and very double, very sweetly scented, produced in great profusion. A great favorite in California and the South. Not hardy in the colder sections.

Mary Washington. Pure white, with double, sweetscented flowers, produced in great profusion in large showy clusters. Relatively hardy.

Mrs. Robert Peary. Pure white; with large double flowers of exquisite form a $\mathrm{n} \mathrm{d} \mathrm{s} \mathrm{u} \mathrm{b}$. stance: very fragrant. A
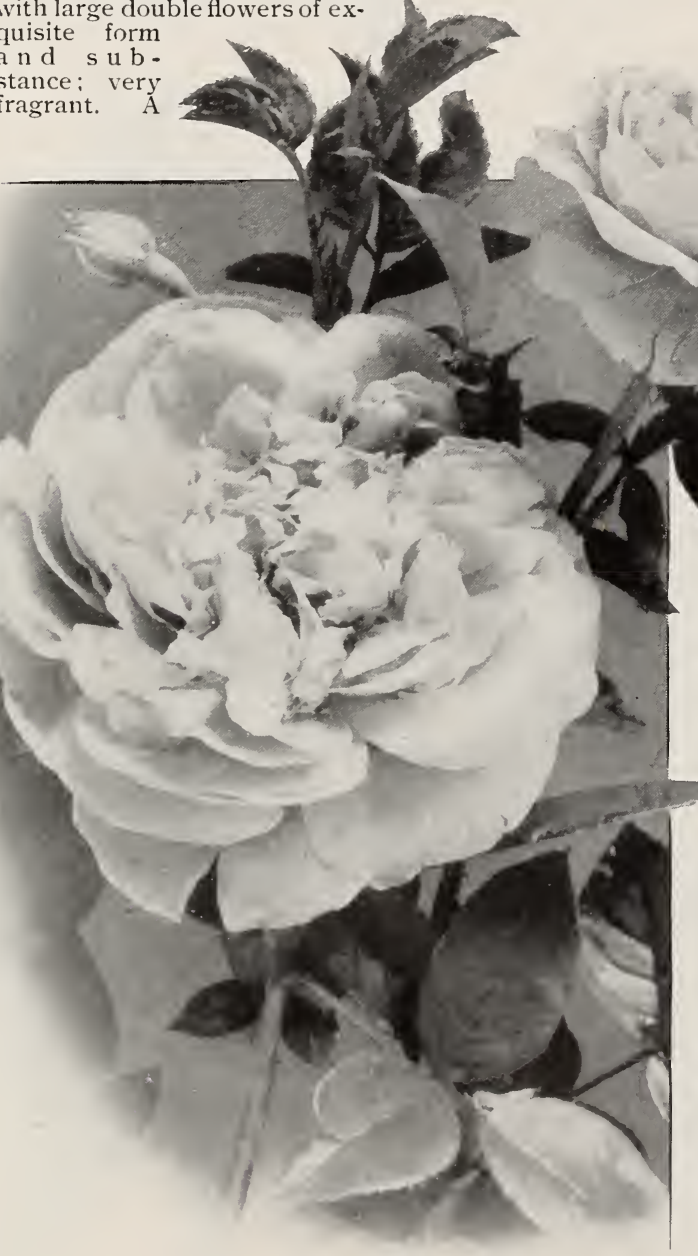

Paul Neyron (see page 47) grand hardy Rose. Vigorous plants, prepaiel, fo cts. each; larger size, purchaser paying transportation, f') cts. each.

Reine Marie Henriette. Glowing crimson, the flowers large and very double, produced in profuse clusters. Relatively hardy.

Any of the Climbing Tea and Noisette Roses, except where noted, strong plants, prepaid, $30 \mathrm{cts}$. each; larger size, purchaser paying transportation, $30 \mathrm{cts}$. each

SPECIAL OFFER. A collection of six of the above, no two alike, our selection of varieties, thrifty plants $\$ 1.65$; stronger plants, purchaser paying transportation $\$ 1.65$.

\section{Hardy Climbing Roses}

Remarkably hardy climbing Roses, which are much esteemed for training over arbors, porches, fences and other objects. They blossom profusely once in each season, the wealth of flowers almost covering the branches. Very little in the way of pruning is necessary, and the plants require no protection.

Baltimore Belle. Blush-white; flowers very double. profusely borne in large showy clusters. Very hardy.

Queen of the Prairies. Bright pink; flowers full and compact, produced in profuse showy clusters. Very hardy.

Tennessee Belle. Blush-rose; flowers large and double, very sweet-scented. Floriferous and hardy.

Any of the Hardy Climbing Roses, strong plants, prepaid, $25 \mathrm{cts}$. each; extra large plants, purchaser paying transportation, $25 \mathrm{cts}$. each.

SPECIAL OFFER. One each of the above, strong thrifty plants, prepaid, 50 cts ; extra strong, purchaser paying transportation, $50 \mathrm{c}$.

\section{Hybrid Perpetual Roses}

Shrubs of vigorous, upright growth, with large, double flowers, which sometimes measure 4 5 inches across. They are very hardy plants, and thrive in almost all localities. It is recommended that a protection of leaves or straw litter be afforded in the colder portions of the country. They are among the most valuable and beautiful of all the Roses. As to pruning, they should be cut back moderately, or if very long stems are wanted at the sacrifice of numbers of flowers, more severe pruning is necessary. The following are among the most noteworthy and desirable varieties:

Abel Carriere. Dark velvety crimson with fiery center; large and very double, of fine form and fragrance.

Alfred Colomb. Bright cherry-red to deep rich crimson; large and extremely fragrant, of good form and substance. A grand Rose.

American Beauty. Rich rosy crimson: remarkably fragrant; large and deep-petaled. A universal favorite. Thrifty plants, prepaid, to cts. each; larger size, purchaser paying transportation, fo cts. each.

Anne de Diesbach. Brilliant carmine; very large and double, delightfully fragrant. A very desirable Rose.

Clio. Flesh-color with rosy pink center ; large globu. lar form; fragrant. A splendid Rose in every way. Strong plants, prepaid, $40 \mathrm{cts}$. each ; larger size, purchaser paying transportation, $40 \mathrm{cts}$. each,

Dinsmore. Glowing crimson, large and showy; flowers very double, clelightfully fragrant. A popular variety

Duke of Edinburgh. Bright crimson, large and full; foliage vigorous and attractive. 
Hybrid Perpetual Roses, continued

Fisher Holmes. Deep velvety crimson with brilliant scarlet center; of good form and substance.

Francois Levet. One of the grand Roses. Cherry-rose; very floriferous and fragrant.

Frau Karl Druschki. Pure white; flowers large and full, of exquisite form and substance. Strong plants, prepaid, 5o cts. each; larger size, purchaser paying transportation, $50 \mathrm{cts}$, each.

Gen. Jacqueminot. Glowing crimson, very soft and velvety. Perliaps the most popular garden Rose.

Giant of Battles. Deep fiery crimson, very brilliant : thowers of good form and substance, delightfully fragrant.

Gloire de Lyonnaise. A rare sliade of salmon-rellow, and the nearest approach to yellow in the Hybrid Perpetual Roses. Flowers full and very sweet-sented.

John Hopper. Bright rose with carmine center; flowers large and full, with excuisite perfume. A grand old stand-by.

Mme. Charles Wood. Bright scarlet, passing to rosy crimson ; flowers large and full, sweetly fragrant. Very free-flowering.

Mme. Gabriel Luizet. Pink or coral-rose, large and very double of good form and substance. A splendid variety. Thrifty plants, prepaid, 4oc. each; larger size, purchaser paying transportation, $40 \mathrm{O}$.

Mme. Masson. Bright rose ; large and full, with exquisite fragrance. A splendid free-flowering variety.

Mme. Plantier. A grand hardy Rose; and one of the best white varieties in the Hybrid Perpetual class. Pure white, large and very double, sweetly fragrant.

Magna Charta. Pink suffused with carmine, large and very double; of fine form and substance. One of the very best.

Margaret Dickson. A magnificent white Rose. Very large, of excellent form and substance, delightfully fragrant. A vigorous and free-flowering variety. Vigorous plants, prepaid, $50 \mathrm{cts}$. each; larger size, purchaser paying transportation, 5o cts. each.

Mrs. John Laing. A very freeflowering, sweetly fragrant Rose. Bright pink, exquisitely shaded; flowers large and double.

Paul Neyron. Probably the largest flower of any Rose. Deep rose to bright pink, very full and double; exquisitely scented. One of the very best. Often blooms with considerable freedom in the autumn.

Prince Camille de Rohan. Deep velvety crimson, almost shaded with black; flowers large and handsome, delightfully fragrant. The darkest-colored Rose. Should be in every collection.

Ulrich Brunner. Cherry-red, flamed with scarlet; flowers large and full, of exquisite form and substance. The buds are perfection in outline and color.

Except where noted, strong plants, prepaid, 35c. each; larger size, purchaser paying transportation, 35c. each.

SPECIAL OFFER. A collection of twelve Hybrid Perpetual Roses, our selection of varieties, no two alike, chosen with regard to a wide range of colors, strong, vigorous plants, prepaid, $\$ 3.50$; larger size, purchaser paying transportation, $\$ 3.50$.

\section{Hybrid Tea Roses}

Vigorous, shrubby Roses, producing a profusion of handsome, fragrant flowers, many of them unsurpassed in brilliancy of color and grace of outline. They are hardy as far north as Memphis and Washington, but require protection in colder climates. 
Hybrid Tea Roses, continued

Meteor. Rich velvety crimson, with wonderfully bright high-lights; flowers large and very double. Splendid for cutting on account of the long stems.

Mme. Abel Chatenay. Rosy carmine, with deeper shades; flowers large, full and double, freely produced throughout the summer.

Mme. Caroline Testout. Satiny rose, deepening to red at the center; flowers large and full, with revolute petals exquisitely burdered with silvery rose.

Pierre Guillot. Brilliant crimson, shading to carmine; flowers large and very double, sweetly scented; very floriferous and remarkable for the dazzling color of the flowers.

Souv. du President Carnot. Blush-rose, with deeper shade at the center: flowers large and double, of extremely graceful outline. Buds long and pointed, very handsome.

Any of the above, prepaid, 35 cts. each; larger size, purchaser paying transportation, $35 \mathrm{cts}$. each.

SPECIAL OFFER. A collection of six Hybrid Tea Roses, our selection of varieties, no two alike, vigorous plants, prepaid, $\$ 1.75$; heavier plants, purchaser paying transportation, $\$ 1.75$.

\section{Japanese Roses}

A comparatively new class of Roses of great hardiness and beauty. They are vigorous-growing shrubs; usually 4 to 5 feet tall, with deep green, more or less

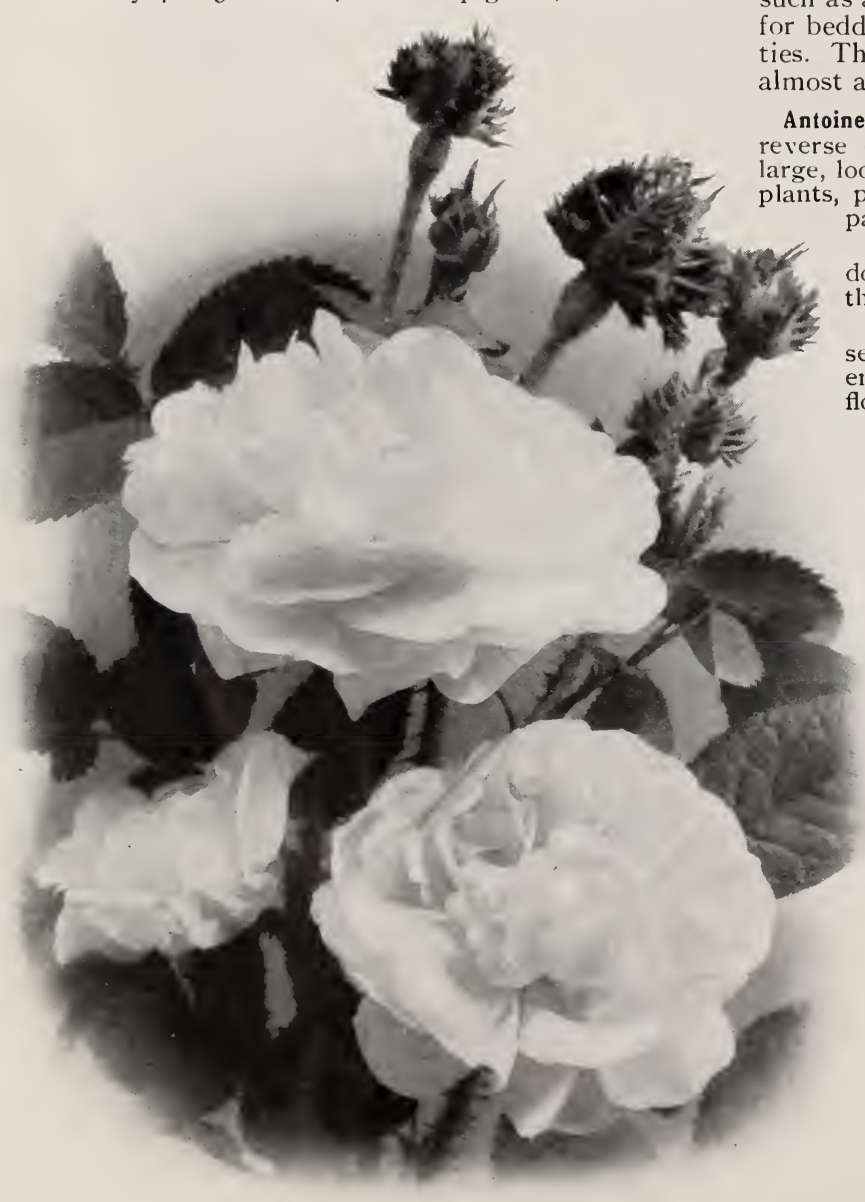

Moss Rose, White Perpetual (see page 49) rugose foliage. They require very little pruning and thrive in almost any soil.

Chedane Guinnoseau. Reddish crimson; flowers double, sweetly scented, continuously borne throughout the summer; berries bright coral-red, very showy.

Conrad F. Meyer. Silvery rose; flowers double, deliciously fragrant, freely produced throughout the season. One of the best.

Mme. Charles F. Worth. Reddish carmine; flowers full and double, produced in large clusters, very sweetscented.

Mme. Georges Bruant. Pure white: flowers loosely double, very fragrant, freely produced throughout the summer.

Any of the Japanese Roses, strong plants, prepaid, 50 cts. each; heavier plants, purchaser paying transportation, 50 cts. each.

SPECIAL OFFER. A collection of three Japanese Roses, our selection, no two alike, strong plants, prepaid, $\$ 1$; heavier plants, purchaser paying transportation, $\$ 1$.

\section{Monthly, or China Roses}

Remarkably free-flowering, and without doubt the most continuous-blooming of the Roses. They are hardy throughout the Southern and Pacific States, but require some protection in the North. such as a covering of straw or loose litter. Splendid for bedding or for grouping in front of taller varieies. They require moderate pruning and thrive in most any garden soil.

Antoinette Cuillerat. White with yellowish center, the A the outer petals carmine-tinted; flowers arge, loosely double, borne in great profusion. Thrifty prepaid, 35 cts. each; larger size, purchaser paying transportation, $35 \mathrm{cts}$. each.

Fellenberg. Deep rosy red; flowers loosely double, very showy, borne in large clusters throughout the season.

Gloire de Rosomanes. Glowing crimson ; flowers semi-double, produced in large clusters at the ends of the branches. Very vigorous and freeflowering. Thrifty plants, prepaid, 35 cts. each larger size, purchaser paying transportation, 35 cts. each.

Lemesie. Clear rose, gradually changing to red; flowers large and full, borne profusely throughout the season. A beautiful and distinct variety.

Serratipetala. Bright rose, gradually deepening to crimson t curious old fashioned variety, with five broad petals and a cluster of numerous narrow petals in the center. Very attractive, exciting comment wherever seen. Thrifty plants, prepaid, 40 cts. each; larger size, purchaser paying transportation, 40c. each.

Viridiflora. Deep green. A curiosity with numerous double, deep green flowers.

Except where noted, strong plants, prepaid, 30 cts, each; heavier plants, purchaser paying transportation, $30 \mathrm{cts}$. each.

SPECIAL OFFER. A collection of three Monthly or China Roses, our selection of varieties, no two alike, strong plants, prepaid, 75 cts. ; larger size, purchaser paying transportation, $75 \mathrm{cts}$.

I am now ready for some more plants and would be glad if you would forward me as promptly as possible the enclosed order. I wish to add that I was very well pleased witl the first shipment of plants received. Yours very truly, C. THOMpsov, Decatur, Ala Nov. 23,1908 . 


\section{BILTMORE, N.C.}

\section{Moss Roses}

Hardy, vigorous-growing shrubs. thriving in a wide range of soil and climate. They require moderate pruning, or, if longer stems are required at the sacrifice of many flowers, they may be more severely cut back. Most of the varieties flower but once during the season.

Blanche Moreau. Pure white; flowers large and sweet, produced in clusters, both flowers and buds invested with a wealth of deep green moss.

Common Moss. Pink or pale rose; flowers large and full, beautifully crested. A strong grower.

Crimson Globe. Crimson; flowers large and very double, of globular outline, very sweet, beautifully mossed.

Crested Moss. Rose or rosy pink: flowers large and full, of exquisite form and substance. One of the most popular varieties.

Salet. Light rose; flowers flattened. very freely produced. Both flowers and buds are crested with moss.

White Perpetual. White; flowers in profuse clusters ; very mossy. A well-known and popular old favorite.

Any of the above, strong plants, prepaid, 35 cts. each; larger size, purchaser paying transportation, $35 \mathrm{cts}$. each.

SPECIAL OFFER. A collection of three Moss Roses, our selection of varieties, no two alike, vigorous plants, prepaid, 85 cts.; larger size, purchaser paying transportation, 85 cts.

\section{Old-Fashioned Roses}

These grand Roses are hardy and very adaptable, thriving in almost any garden soil. They require comparatively little pruning and attention.

Cabbage or Provence. There are both white and red forms. Flowers large, full and double, deliciously fragrant.

Celestial. The old-fashioned Celestial Rose, white and fragrant. No sweeter Rose in cultivation.

Damask. Deep rose, flowers large and double, very fragrant. Forms a round compact shrub with handsome deep green foliage which is retained until late autumn.

Maiden's Blush. Blush-white; flowers full and double, very sweet.

Perpetual. Delicate blush; very fragrant, blossoming throughout the season.

Tuscany. Dark velvety crimson. One of the richest colored of all the old-fashioned Roses.

Any of the above, strong plants, prepaid $35 \mathrm{cts}$. each; larger size, purchaser paying transportation, 35 cts. each.

SPECIAL OFFER. A collection of three Old-Fashioned Roses, our selection, no two alike, strong plants, prepaid, 85 cts.; larger size, purchaser paying transportation, 85 cts.

\section{Polyantha Roses}

Dwarf, bushy shrubs, with very double, fragrant flowers, produced in large and profuse clusters. They are often and most successfully used as hedge plants or for bordering garden beds. They require rather severe pruning in spring in order to perpetuate a

leafy, floriferous growth. They are relatively hardy, but require protection in very cold climates.

Baby Rambler. Crimson-red; flowers borne in great profusion, in broad clusters, throughout the season. Forms a compact bush about 2 feet high. Vigorous plants, prepaid, $35 \mathrm{cts}$. each; heavier plants, purchaser paying transportation, $35 \mathrm{cts}$. each.

Clothilde Soupert. Irory-white, shading towards the center to silvery rose; flowers freely produced in clusters, throughout the season. A grand free-flowering variety.

Etoile d'0r. Pale vellow, changing to rosy red at the center: flowers full and very double, borne in large clusters.

Marie Pavie. Creamy white, flushed with rose, full and double, borne in great profusion in broad clusters; delightfully perfumed.

Except where noted, strong plants, prepaid, $30 \mathrm{cts}$. each; larger size, purchaser paying transportation, 30 cts. each.

SPECIAL OFFER. A collection of three Polyantha Roses, our selection of varieties, no two alike, strong plants, prepaid, $75 \mathrm{cts}$; heavier plants, purchaser paying transportation, 75 cts.

Enclosed herewith please find remittance for which kindly send me Iris Germanica, "Prince of Wales," to that value. I was well pleased with what vou sent me a short time ago.F. S. KINSEY, 920 Church St., Reading, Pa., April II, 1908 . 


\section{Rambler Roses}

Remarkably vigorous and rapid-growing Roses, often producing shoots 10 to 20 feet in length in a single season. They are well adapted for training against pillars or other supports, and produce a brilliant effect by the wonderful profusion of their flowers, which appear in early summer. They are very hardy and thrive in any fertile soil.

Crimson Rambler. Glowing crimson ; flowers produced in great profusion, in large pyramidal russes. A grand Rose for porches or arbors, or for training on fences. One of the most popular Roses of the period.

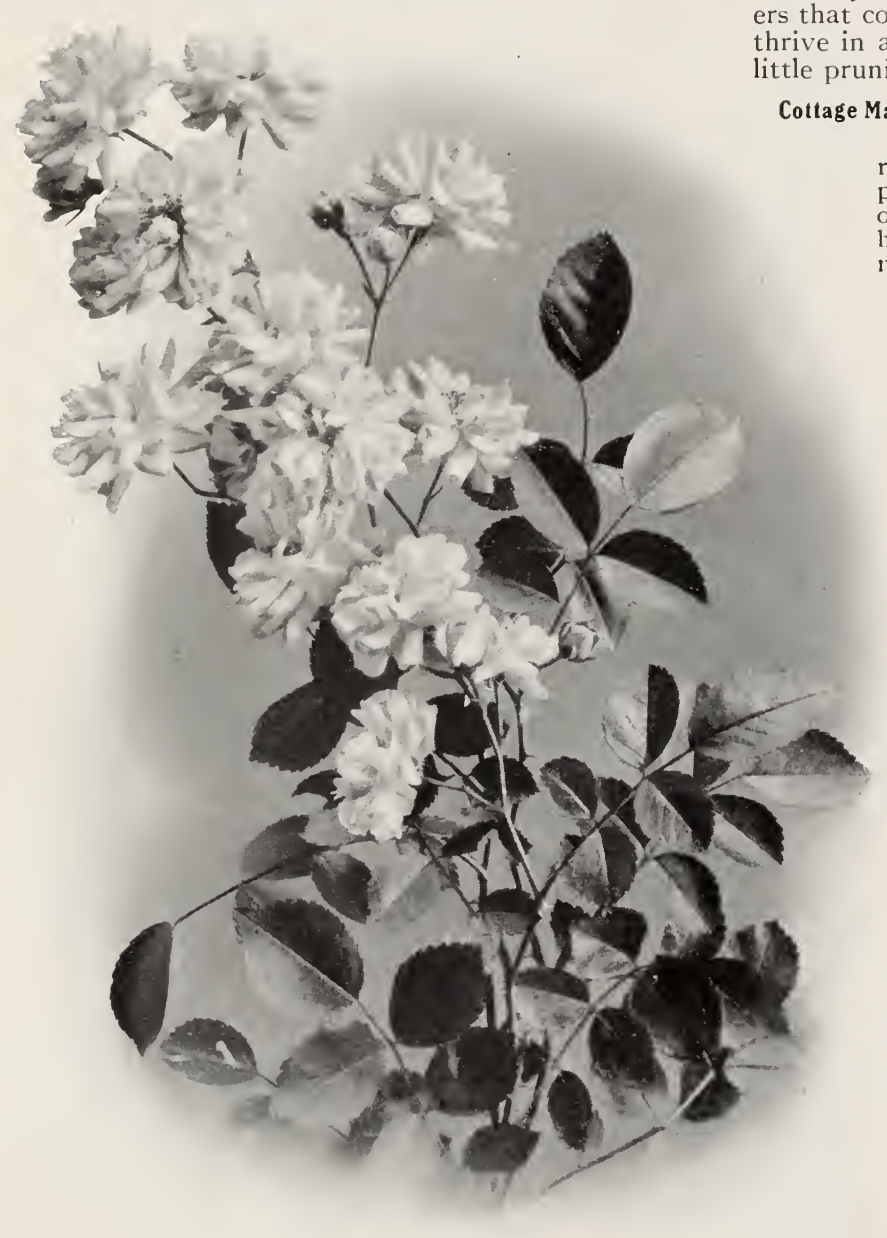

Dorothy Perkins (see page 51)

Philadelphia Rambler. A variety of the Crimson Rambler with brighter and more deeply colored, perfectly double flowers. Of exquisite form and substance, and lacking the faded appearance sometimes seen in the typical form. Strong plants, prepaid, $35 \mathrm{cts}$. each ; lieavier plants, purchaser paying transportation, 35 cts. each.

Pink Rambler (Psyche). Light pink, suffused with salmon-rose and deeper pink, the base of the petals pale yellow. Very vigorous.

Yellow Rambler (Aglaia). Light yellow, changing to straw-color. Very floriferous. The very double flowers are produced in large clusters, and continue to appear for three or four weeks.
White Rambler (Thalia), IIhite, sonetimes with faint blush; flowers profuse and very fragrant, borne in large compact clusters.

Except where noted, strong plants, prepaid, $30 \mathrm{cts}$. each; larger size, purchaser paying transportation, 30 cts. each.

SPECIAL OFFER. A collection of four Rambler Roses, our selection of varieties, no two alike, prepaid, $\$ 1$; larger size, purchaser paying transportation, $\$ 1$.

\section{Striped Roses}

Hardy shrubs, with quaint and very pretty flowers that command attention wherever seen. They thrive in almost any garden soil, and require very e pruning.

Cottage Maid. White, striped with rose. Very dainty: York and Lancaster. IIhite, striped with red. A legend associated with this Rose proclaims the blending of the warring clans of York and Lancaster, who fought in the historic IVars of the Roses under the insignia of white and red Roses.

Either of the Striped Roses, strong plants, prepaid, 50 cts. each; larger size, purchaser paying transportation, $50 \mathrm{cts}$.

\section{Tea Roses}

Handsome free-flowering shrubs, with showy and delightfully fragrant flowers. They are well adapted for bedding in the open ground and thrive in any good garden soil. They require protection in cold climates during the winter, such as would be afforded by litter, straw or evergreen boughs.

Aline Sisley. Reddish purple, toned with crimson and maroon; flowers large and double, of exquisite form and fragrance. Highly recommended.

Bon Silene. Deep rose, or rosy crimson; flowers full and fragrant. The buds are very large and of superb outline. One of the best.

Bridesmaid. Clear rich pink; flowers large and fragrant, especially beautiful in the bud. A grand bedding Rose.

Cornelia Cook. Creamy white, faintly tinged with lemon-yellow; flowers very double, produced in great profusion, of exquisite form and substance. Splendid for bedding.

Devoniensis. This is the Magnolia Rose of the South. Creamy white with rosy center; flowers large and double, deliciously fragrant. A deservedly universal favorite.

Etoile de Lyon. Golden vellow; flow ers very deep and full, sweet-perfumed. One of the best Roses in its class.

Maman Cochet. Clear pink, changing to silvery rose; flowers large and double, of graceful outline and delicate fragrance. A superb bedding Rose.

Marie Guillot. White, faintly tinged witl pale vellow ; flowers large, full and double, very fragrant and showy. One of the best white Roses for outdoor culture of its class.

Papa Gontier. Cherry-red, changing to glowing crimson, very fragrant ; buds very large, of exquisite outline. Highly recommended.

Perle des Jardins. Golden yellow; flowers large, of a distinct globular form, richly perfumed. An old-time favorite, and one of the finest yellow Roses. 


\section{BILTMORE, N.C. T. W W}

Tea Roses, continued

Safrano. Apricot-yellow, changing to deeper tones of orange, rose and fawn.

The Bride. Pure white; flowers large and very double, richly perfumed. V'ery beautiful in bud. In the open ground the flowers are often tinged with pink.

Any of the above thrifty plants, prepaid, 30 cts. each; larger size, purchaser paying transportation, 30 cts. each.

SPECIAL OFFER. A collection of twelve Tea Roses, our selection, no two alike, embracing a wide range of colors, vigorous plants, prepaid, $\$ 3$; heavier plants, purchaser paying transportation, $\$ 3$; half sets as above, $\$ 1.50$.

\section{Wichuraiana Hybrid Roses}

A comparatively new race of hardy Roses, adapted for training on pillars, fences or trellises, or as a ground cover where other Roses would be unlikely to thrive. They thrive in almost any kind of soil, but of course amply repay the planter for providing fertile and congenial surroundings The flowers are borne in great profusion in late spring or early summer, and continue for a period of three or four weeks. The foliage is remarkably lustrous and remains green until midwinter

Debutante. Soft pink; flowers double, in clusters, very fragrant, with the delicate odor of the Sweet Brier. Foliage dark glossy green. Splendid for training on trellises or trailing on the ground.

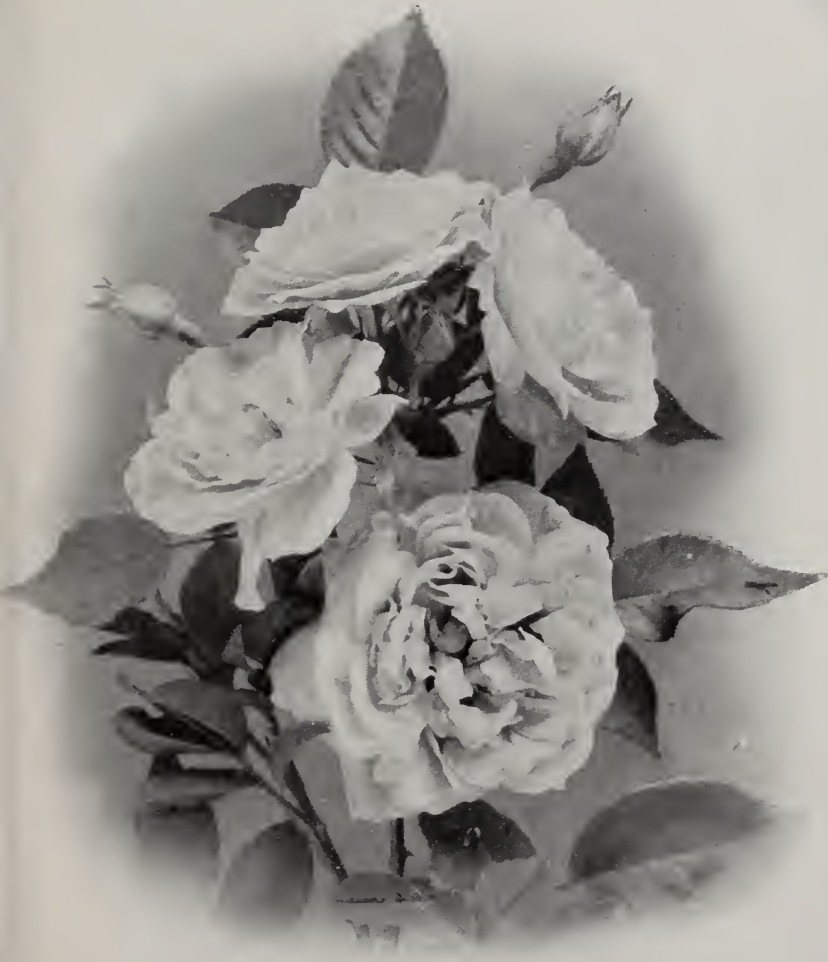

Hermosa (see page 45 )

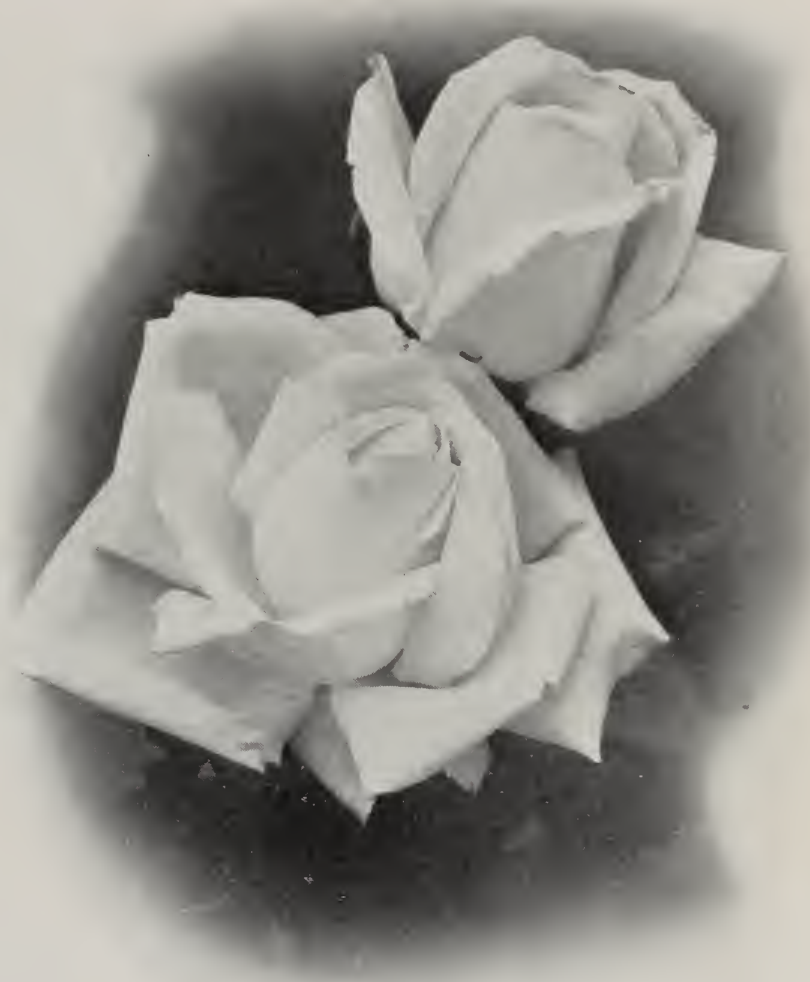

Frau Karl Druschki (see page 47)

Dorothy Perkins. Clear shell-pink; flowers profusely borne in numerous clusters, full and double, with crinkled petals. Leaves bright green and lustrous, persisting until early winter. A grand Rose for training or for ground cover. In our estimation this is one of the best varieties of its class for planting against porches and verandas. Try it.

Pink Roamer. Bright pink with a white center, often flushed with red; flowers profuse, large and showy, with the fragrance of the Sweet Brier. Foliage rich green and lustrous, persistent until early winter.

Sweetheart. Bright pink in bud, changing to white when fully expanded; flowers large and showy, deliciously fragrant. Foliage dark glossy green, persisting until early winter.

Wm. C. Egan. Rosy pink; flowers large and very double, sweetly fragrant, borne in great profusion in late spring or early summer. Foliage bright green and lustrous, persisting until early winter. A grand Rose.

Any of the above, strong plants, prepaid, $30 \mathrm{cts}$. each; heavier stock, purchaser paying transportation, 30 cts. each.

SPECIAL OFFER. Three Wichuraiana Hybrid Roses, our selection, no two alike, strong plants, prepaid, 75 cts.; heavier plants, purchaser paying transportation, 75 cts.

The plants came yesterday and in fine condition. I shall remember where to ret good plants or shrubs in the future. H. W. RoBERTS, Ottumwa, Iowa, April 27, 1907.

The package of plants sent me to Leesport, Pa., was received in due time and I am delighted with the articles. Frank B. Brown, Editorial Dept. "Reading Eagle," Reading, Pa., May $10,1807$. 


\section{BILTMORE NURSERY W XE}

\section{Salix}

Salix caprea. Pussy WILlow. GOAT Willow. Fair harbinger of Spring-the joy of children and the awakening messenger of sweet memories for the contemplation of their elders! The fuzzy catkins, glistening in their robes of silk and gold, present an aspect full of charm and bright ness. A small and hardy tree, handsome in flower and greatly esteemed by reason of its extreme earliness. Vigorous young plants, prepaid, 25 cts. each ; larger sizes, purchaser paying transportation, 25c. and 50c. each.

\section{Sambucus - The Elders}

The effect of blossoming Elders, with their huge and flattened flowerclusters of creamy white so boldly contrasted against the greenery of the feathery foliage, is dramatic and delightful. They are splendid border plants, of a most vigorous, hardy type, and besides their showy flowers, afford large quantities of early ripening berries which attract many kinds of birds that love to feast upon them

Sambucus canadensis. AMERICAN ELDER. A tall and rapid growing shrub deserving of more extended cultivation. Flowers creamy white, in huge flat-topped clusters in early summer, soon followed by a wealth of black or purplish berries. Grows 6 to io feet tall.

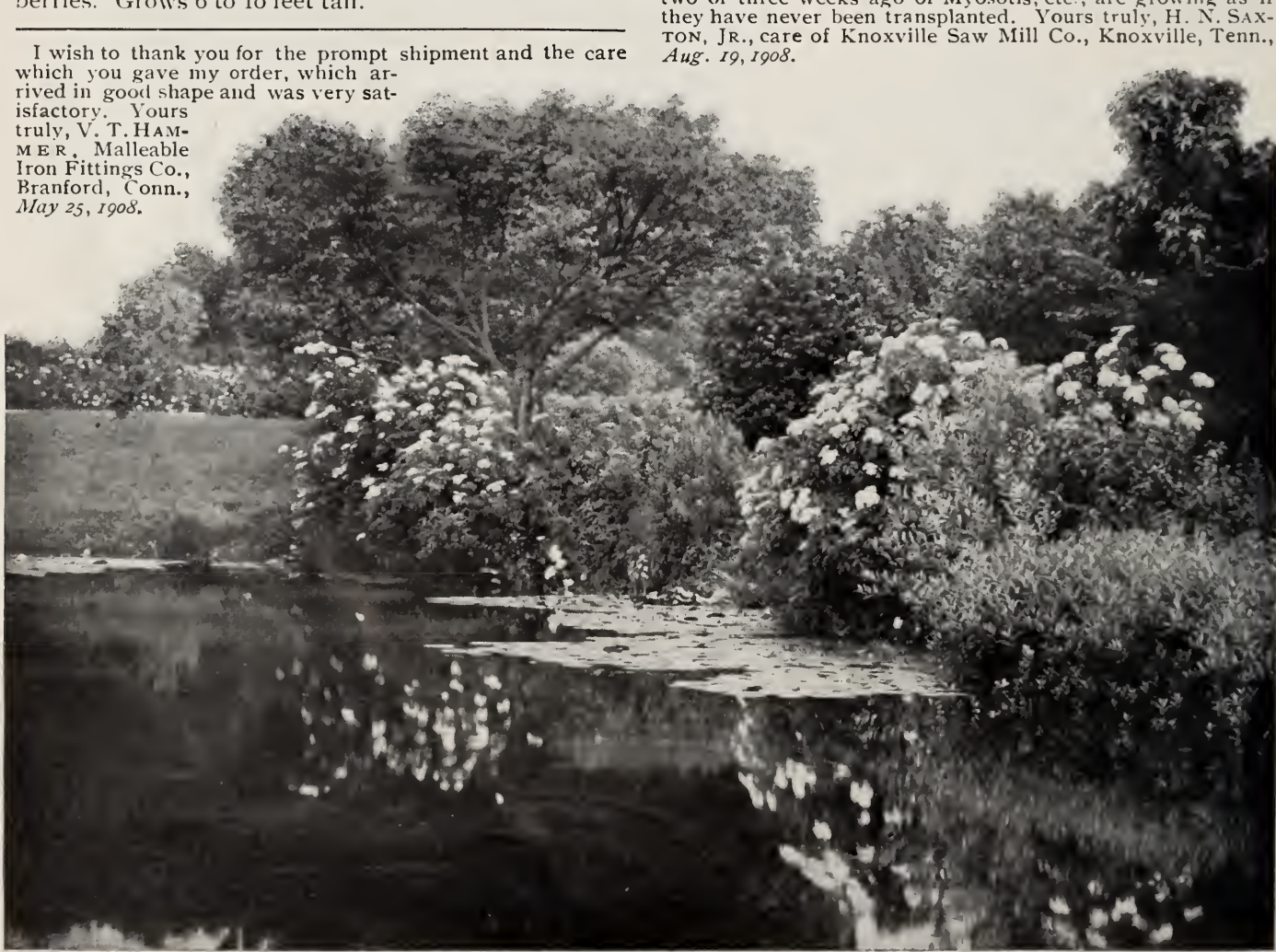

The delightful and dramatic effect of Sambucus canadensis

\section{Sambucus, continued}

Sambucus pubens. RED-BERRIED ELDER. A splenoften with ripe fruit when the latter is in blossom. Flowers creamy white, in large showy clusters in late spring. Berrie bright red, ripening in early summer. Attains a height of 5 to - feet.

Either of the Elders, strong plants prepaid, $25 \mathrm{cts}$. each; larger shrubs, purchaser paying transportation, 25 cts. and 35 cts. each.

\section{Schizophragma}

Schizophragmahydrangeoides. CLIMBING HVDRANGEA. Something new in vines-one with large showy blossoms-is found in the beautifu Climbing Hydrangea, which is par ticularly well adapted for covering with a rich drapery of green, walls of wood or masonry. The handsome white flowers are profusely borne in broad flat-topped clusters, with the marginal flowers radiate and vei showy. Thrives best in moist rich loam in partial shade, and is hardy as far north as Missouri and Massachusetts. Thrifty plants, prepaid, 5 cts. each ; larger sizes, purchaser paying transportation, $50 \mathrm{cts}$. and $75 \mathrm{cts}$. each.

As I wrote you before, everything I have ordered from you is growing nicel, , ever
the plants 1 ordered too late last spring. ordered from you is growing nicel, , ever
the plants 1 ordered too late last spring. have not lost one of them, and the little order you sent me two or three weeks ago of Myosotis, etc, are growing as if they have never been transplanted Yours truly, H S SAX. did companion plant for the American Elder 


\section{BILTMORE, N.C.}

\section{Sophora}

Sophora japonica. PAGODA TREE. With grace and beauty hand in hand, this rare and relatively hardy tree appeals to those who prize distinctiveness. The green-barked twigs, which retain their verdant color even in midwinter, uphold the feathery foliage as a background for the large loose panicles of cream-white flowers, so bountifully produced in midsummer. In the autimn the leaves assume soft tones of gold and yellow. Unique. Thrifty young trees, prepaid, $75 \mathrm{cts}$. each; larger sizes, purchaser paying transportation, 75 cts., \$I and \$I.5O each.

\section{Sorbus . The Mountain Ash and White Beam Trees}

Particularly bright and attractive trees for the lawn, both for their broad clusters of showy flowers and brilliant berries. The marked individuality of these hardy ornamentals is delightful; in foliage, in flower and in fruit, the traits are peculiarly their own. Birds eagerly seek the ripening berries, and a few trees near the house will give bird-lovers much pleasure in early autumn.

Sorbus aria. White BeAll Tree. A small tree with a compact oval crown. Flowers white, in broad, flat topped clusters, opening in late spring or early summer. The leaves are simple, deep green above, whitewoolly beneath, turning yellow in autumn. Berries orange-red. When the foliage is ruffled by the winds the contrasting colors of the leaf-surfaces are very effective. Strong plants, prepaid, 50 cts. each; larger sizes, purchaser paying transportation, 50 cts. and 75 cts. each.

S. aucuparia. Mountain Ash. Rowan Tree. The broad flat clusters of white flowers which open towards the end of spring are extremeiy beautiful, and contrast strongly against the dark green of the feathery foliage. Before the golden tints of autumn light the leaves, the profuse and showy berries glow in ruddy splendor from the tips of heavy-laden branches. Strong plants, prepaid, 25 cts. each; larger sizes, purchaser paying transportation, 25 cts., $50 \mathrm{cts}$. and 75 cts. each.

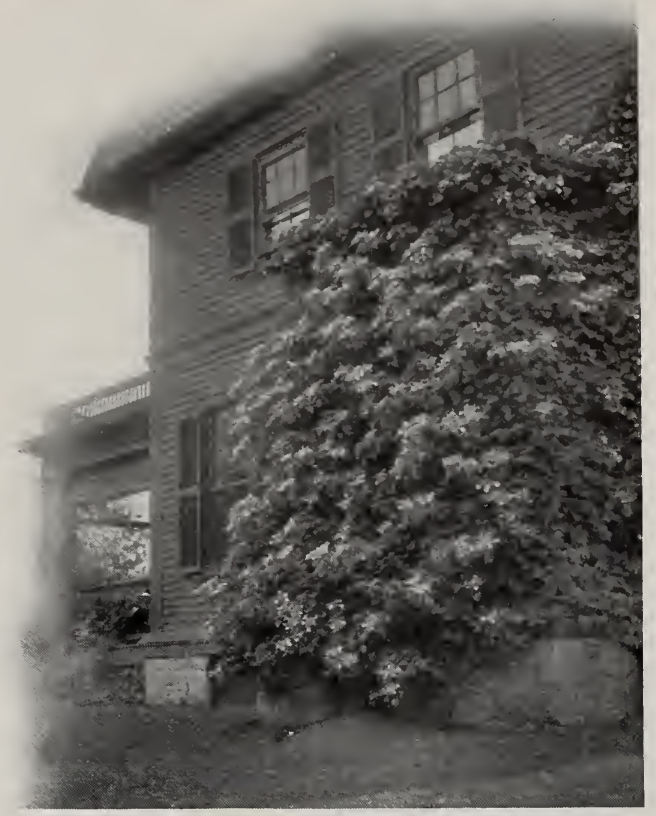

Schizophragma hydrangeoides (see page 52)

\section{Spartium}

Spartium junceum. SPANish BroOM. A strange and curious plant with long and rush-like green-barked branches. Flowers yellow, in showy clusters or racemes, blossoming for long periods, or, in the South, almost throughout the year. Hardy as far north as Memphis and Washington, and especially valuable for the Southern and Pacific States. Grows 4 to 6 feet tall. Extremely interesting, attracting attention wherever seen. Thrifty plants, prepaid, 25 cts. each; larger sizes, purchaser paying transportation, $25 \mathrm{c}$. and $5 \mathrm{Oc}$. ea.

\section{Spiræa - The Spireas}

Of all the garden shrubs, and there are keen rivals in many noble ranks, the Spireas have won and held a popularity for hardiness, showiness and free-flowering traits, that is unexcelled. Really of inestimable value in plantations, for among the species may be found those that produce a profusion of blossoms in earliest spring, others that bloom at later intervals, and even varieties that continue to produce flowers from midsummer until checked by frost. In general, they are graceful, compact bushes, thriving in almost any sunny situation.

Spiraea alba. MEADOW SwEET. An upright free flowering shrub with reddish brown branches, eventually 3 to 5 feet high. Flowers white, in large dense, plume-like clusters in summer. A splendid companion plant for the pink-

Sophora japonica 


\section{BILTMORE NURSERY W W}

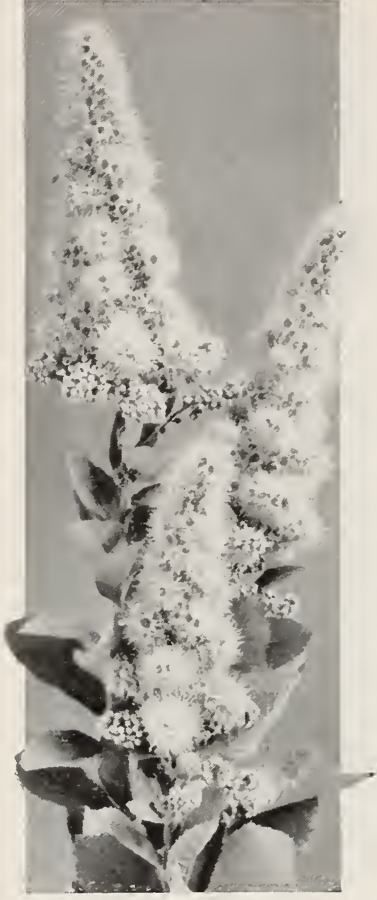

Spiræa billardi
Spiraea, continued plumed Spirea, contrasting the color effects in a most happy manner.

S. albiflora ( $S$. japonica $a ! b a)$. DWARF IVhite SPIREA. A low dense shrub with rigid upright branches. Flowers white, in numerous flat-topped clusters in summer, appearing like a crown of blossoms set with infinite skill and bea uty. Remarkably neat and attractive.

S. arguta. HYBR I D S NOW-GARLAND. A wonderfully showy and floriferous shrub, growing 3 to 5 feet tall. Flowers pure white, appearing in bewildering profusion in early spring, covering the plant like a mantle of snow. Very hardy, and one of the best of the very early Spireas. Strong plants, prepaid, 25 cts. each; larger sizes, purchaser paying transportation, $25 \mathrm{cts}$. and $35 \mathrm{cts}$. each.

S. billardi. P INK PLUMED SPIREA. An erect, free-flowering shrub with brownish branches, growing 3 to 5 feet tall. Flowers bright pink, in dense fluffy plumes in summer. Very showy and attractive, and splendid for cut-flowers.

S. bumalda, Anthony Waterer. CRIMSON SPIREA. A remarkably floriferous shrub with upright branches, attaining a height of 2 to 3 feet. Flowers bright rosy crimson, displayed in large flat-topped clusters throughout the summer and autumn. Magnificent.
Spiraea cantonensis flore pleno ( $S$. reevesiana). LANCE LEAVED DOUBLI. SIIREA. A graceful, hand some shrub with slender arching branches, attaininu a height of 3 to 5 feet. Flowers pure white and very double, pr ssessing remarkable texture and durability. The blossoms unfold in midspring.

S prunifolia flore pleno. BRIDAL Wreath. One of the grandest of garden shrubs. A charming tall-growing form with slender, often recurved branches that are densely laden in early spring with showy blossoms. The snow-white flowers, like miniature roses, are very full and double; the climax of perfection in every detail. The lustrous bright green leaves assume brilliant orange tints in autumn.

S. thunbergi. SNow GARLAND. A beautiful shrub with numerous slender

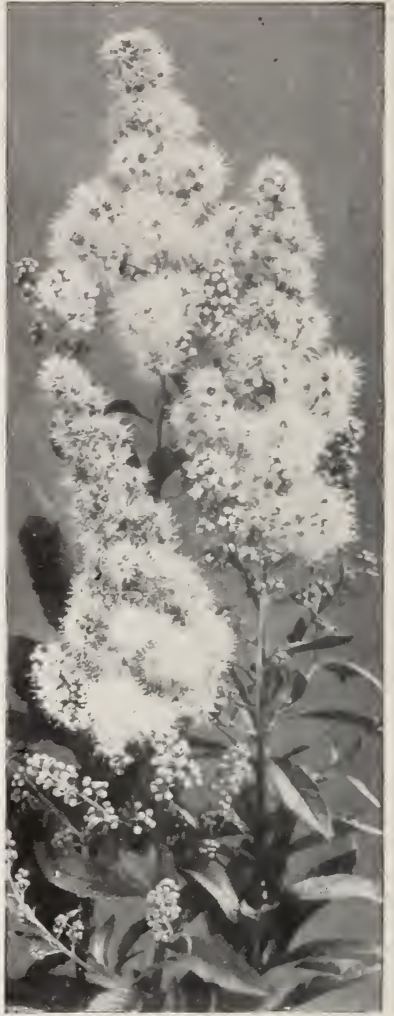

Spiræa alba dense feathery bush 3 to 4 feet tall. Flowers pure white, so profusely borne in earliest spring as to appear like a snow mantle. The bright green foliage assumes in autumn brilliant tones of orange and scarlet. Splendid, really splendid.

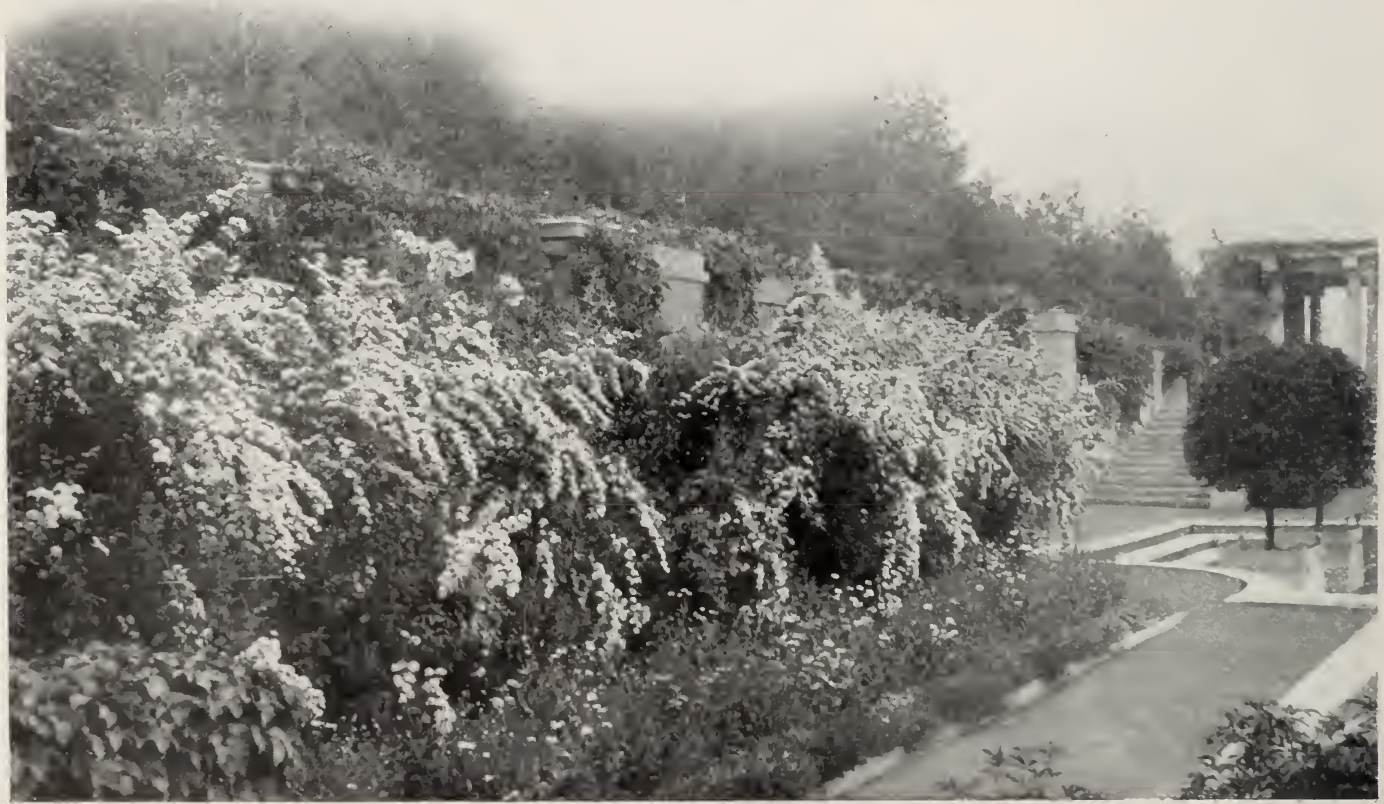

The grace and charm of Spiræa vanhouttei 


\section{BILTMORE, N.C.}

\section{Spiraea, continued}

Spiraea vanhouttei. VAX HOUTTE'S BRIDAL WREATH. A grand and graceful shrub with numerous arching branches, attaining a height of 5 to 6 feet. Blossoms white, produced in a wonderful galaxy of dainty clusters in harmonious arratlgement along the densely flower-laden branches towards the end of spring. One of the best.

Except where noted, strong plants, prepaid, 15 cts. each; larger sizes, purchaser paying transportation, 15 cts. and 25 cts, each.

SPECIAL OFFER. A collection of six Spireas, our selection of varieties, embracing both early-and summer-flowering forms, no two alike, strong plants, prepaid, 75 cts.; larger sizes, purchaser paying transportation, 75 cts. and $\$ 1.25$.

\section{Staphylea - The Bladder-nuts}

How often it is that the unusual shrub or plant gives us zest and keen interest in our garden! With an aspect of exclusiveness, both in outline and in inflorescence, the Staphyleas invariably attract attention by their dainty white blossoms and curious inflated seed-pods. That they are rare in cultivation only makes them more inviting, and their hardiness and vigor adapt them to almost any situation.

Staphylea colchica. Colchicax BLADDER-NTT. A tall upright shrub usually growing io to 12 feet tall. Flowers white, disposed in broad, often nodding, showy clusters in early summer. Pods large and much inflated. Very ornamental and attractive.

S. trifolia. AYERICAN BLADDER-NCT. A vigorous and very hardy shrub with stout upright branches, attaining a height of Io to I2 feet. Blossoms white, in nodding raceme-like clusters in late spring. Pods 3lobed, much inflated.

Either of the Bladder-nuts, strong plants, prepaid, 25 cts. each; larger sizes, purchaser paying transportation, 25 cts., 35 cts. and 50 cts. each.

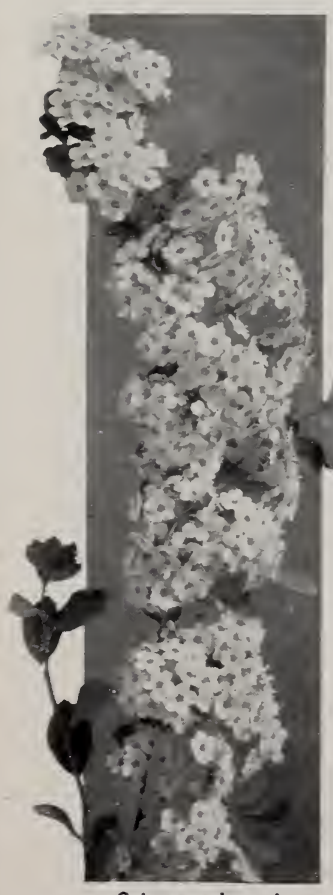

Spiræa vanhouttei

\section{Stephanandra}

Stephanandra flexuosa. STEPHA.AXDRA. When beauty, grace and daintiness combine in plenteous measure to perfect the work of Nature, the result can only be superlative and grand. And so it is with the Stephanandra, where all these attributes are in accord and, blended, form the type of excellence which has made it popular and renowned. The deep green lustrous leaves which clothe the arching branches are tinged with red as they unfold, and in autumn fade with brilliant tones of vellow, red and purple. The flowers are creamy white, and appear in early summer in soft feathery racemes in great profusion. Grows 3 to 4 feet tall. A gem. Thrifty plants, prepaid, I5 cts. each; larger sizes, purchaser paying transportation, I5 cts. and 25 cts. each.

The plants you sent us arrived in good condition and are started al good condition and are started al-
ready. IVe are very much pleased with them and appreciate the extra plants you put in. Yours truly, L. Macl. Howell North Vancouver B. C., May 30, 1908 .

\section{Stuartia - The Stuartias}

These handsome shrubs have been aptly called the Hardy Camellias," for in many respects the blossoms closely resemble those of the charming single-flowered white Camellia. The foliage of the Stuartias is deciduous, bright lustrous green during the growing season, changing in autumn to brilliant, often glowing, shades of orange, red and scarlet. They thrive in moist, fertile soils, preferring sunny exposures. Worthy of a prominent place.

Stuartia pentagyna. ALLEGHANY STLARTIA. A rare and splendid shrub with spreading branches, usually growing 5 to 8 feet tall. Flowers white, large and very beautiful, with rosebordered petals and numerous gold-tipped stamens, opening for severa! weeks in summer. Really grand. Vigorous plants, prepaid, $25 \mathrm{cts}$. each ; larger shrubs, purchaser paying transportation, $25 \mathrm{cts}$. and $50 \mathrm{cts}$. each.

S. pseudo=camellia. JAPANESE STUARTIA. A large shrub with upright branches, growing 8 to Io feet tall. Flowers very showy, about two inches across, pure white, with silky petals and numerous orange stamens, blossoming in summer Exquisite. Thrifty plants, prepaid, $50 \mathrm{cts}$. each: larger sizes, purchaser paying transportation, 5oc. and $75 \mathrm{c}$.

\section{Styrax - The Storax Shrubs}

Closely grouped together under the sequence here adopted, the letter "S" presents a galaxy of flowering shrubs of unusual excellence, of which the present subjects are no exceptions to the illustrious group. The Storax bushes are handsome and freeflowering, producing in early summer a bright array of fragrant blossoms, the acme of grace and purity. They thrive in well-drained, loam soils, and are hardy as far north as Massachusetts and Missouri.

Styrax americana. AMERICAX STORAX. A spreading shrub, usually growing + to 6 feet tall. Flowers brilliant white, nodding in graceful clusters amid the leaves of slender branches. A refined and dainty object. Vigorous plants, prepaid, $50 \mathrm{cts}$. each; larger sizes, purchaser paying transportation, $50 \mathrm{cts}$. and 75 cts. each.

S. japonica. JAPANESE STORAX. A graceful shrub with spreading branches and pleasing bright green foliage. Flowers snow-white, in numerous drooping racemes, both fragrant and showy. A remarkable and really splendid plant as an outstanding specimen on the borders of the lawn, usually growing \& to Io feet tall. Vigorous plants, prepaid, 50 cts. each; larger sizes, purchaser paying transportation, $50 \mathrm{cts}$. and 75 cts. each.

S. obassia. BROAD-LEATED STORAX. A vigorous tall shrub with large broad leaves. Flowers pure white sweetly fragrant, freely produced in graceful drooping racemes + to 6 inches long. A very showy and distinct variety. Thrifty plants, prepaid, 75 cts. each: larger shrubs, purchaser paying transportation, $75 \mathrm{cts}$. and \$i.5o each. 

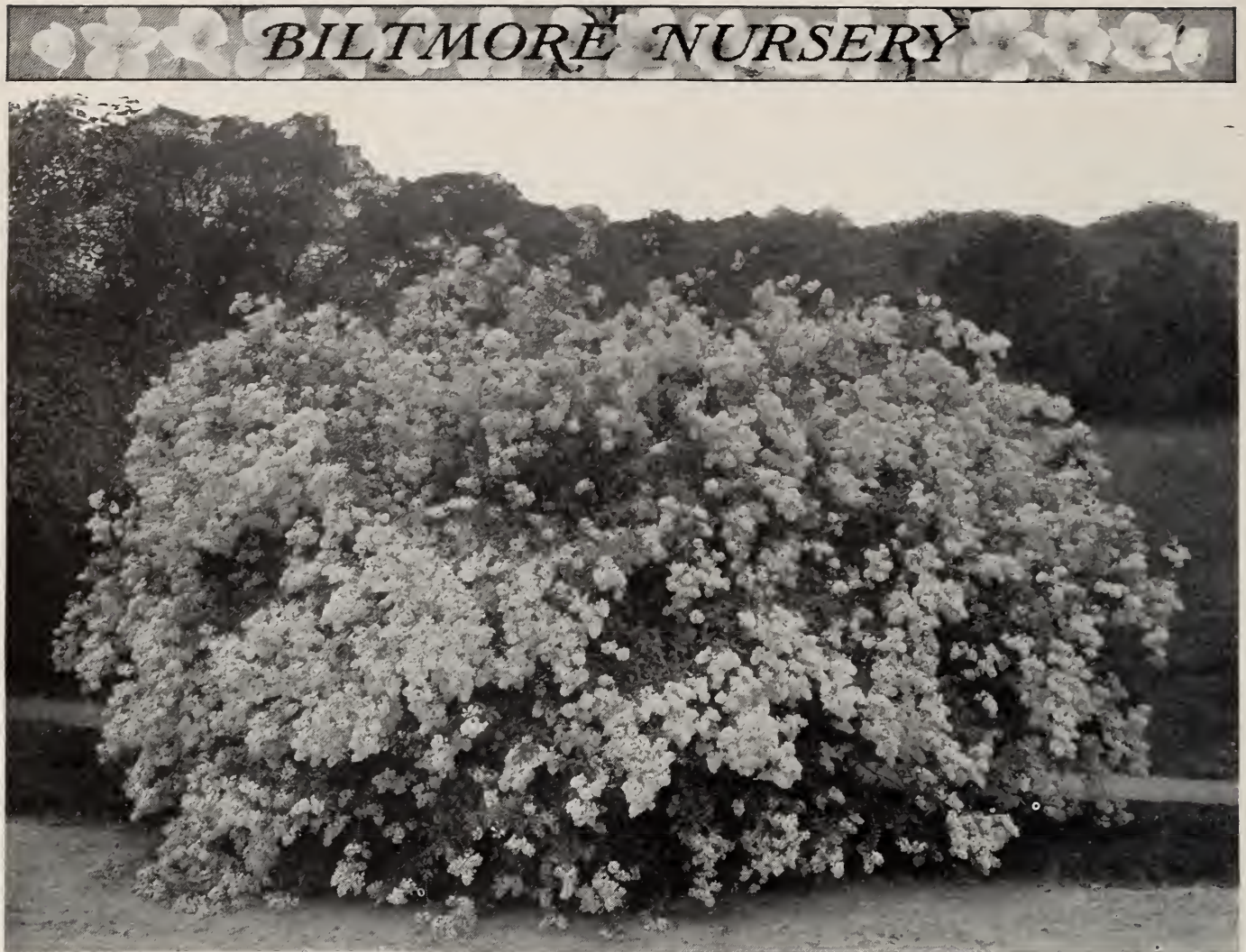

\section{The mid-spring beauty of Syrnga chinensis}

\section{Syringa - The Lilacs}

"Flowers preach to us, if we will hear." Yes, and few there are who have not viewed them with silent lips in contemplation of their joyous message. The uplift is inspiring, and more so when the flowers

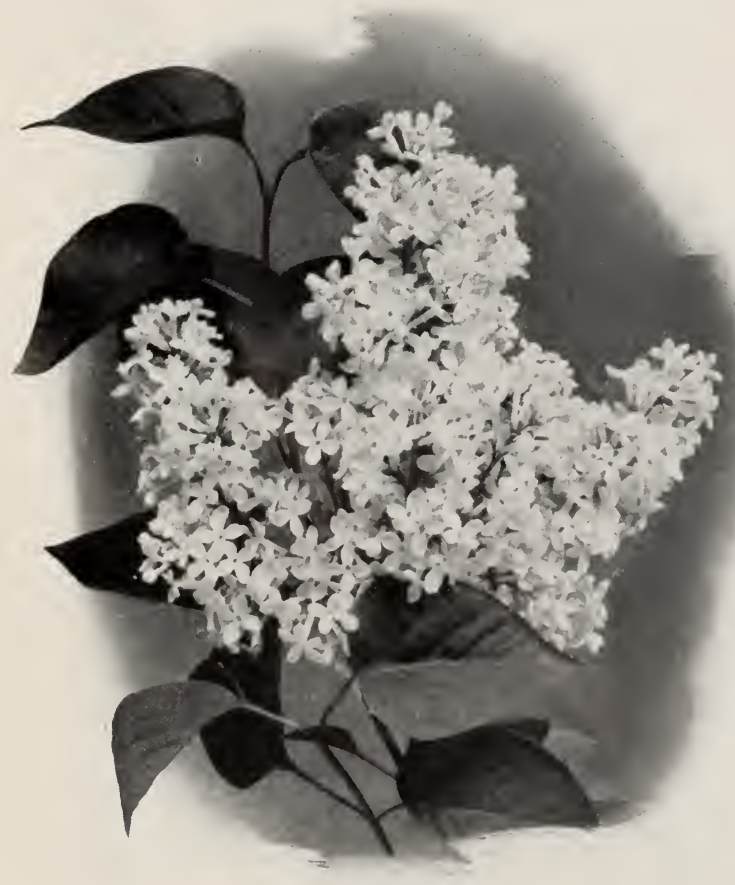

Syringa vulgaris that speak are those we love and know so well. The message of the Lilacs, these glorious old-time flowers, is like a ray of sunshine, dispelling clouds and mist. Their beautiful and fragrant blossoms are among the garden's choicest gifts, and impart a cheerful radiance to the home.

Syringa chinensis (S. rothomagensis). ROUEX LILAC. A graceful shrub with slender, often arching branches, growing 8 to ro feet tall. The showy lilac-purple flowers which mark the mid-spring beauty and display, are so lavish in their numbers that they bend the branches by sheer weight. Very handsome and free-flowering.

S. persica. PERsidx LiLAC. With graceful slender stems reaching a height of 6 to 8 feet, this distinct and pretty Lilac makes an attractive shrub for specimen planting or massing in the borders. The flowers are pale lilac or white, opening in late spring, and appear in garland-like masses along the curving branches. Your choice of colors.

S. vulgaris. Commox Lit.Ac. The grand old Lilac, the spring-time glory of many gardens, still claims our friendship and esteem, and the circle of its popularity yearly widens. The handsome, richly fragrant blossoms, in pyramids and spires, are costumed in white or shades of pink. lilac and blue, both in single- or double-flowered forms. The range of selection is very great, and the splendid effect of a well-chosen group with contrasting colors is a life-long inspiration. Your choice of colors and forms.

Any of the Lilacs, strong plants, prepaid, $15 \mathrm{cts}$. each; larger sizes, purchaser paying transportation, $15 \mathrm{cts}$., $25 \mathrm{cts}$. and $35 \mathrm{cts}$. each.

SPECIAL OFFER. A collection of six distinct varieties of the Common Lilac, our selection of kinds, embracing both single- and double-flowered forms of sterling merit, strong plants, prepaid, $75 \mathrm{cts}$.; larger sizes, purchaser paying transportation, 75 cts. $\$ 1$ and $\$ 1.25$. 


\section{Tamarix - The Tamarisks}

The feathery aspect of Tamarisks, when densely clothed with myriads of flowers of pink, is an impressive and beautiful sight. The slender branches, fairly hidden by the affluence of the blossoms, appear like garlands deftly made of plumes. They are graceful, quick-growing shrubs of easy culture, thriving in almost any soil, and are also well arlapted for seaside planting.

Tamarix gallica $(T$. pentand, $a)$. FRENCH TANAARISK. A tall shrub with slender spreading branches and blue-green leares resembling those of Cedars. The showy pink flowers appear in late spring or early summer, and adorn the plant with a bewildering array of fluffy plumes. Remarkably attractive and distinct.

T.parviflora. EARLY-FLOWERING TAMARlsk. A vigorous slirub witl spreading branches and bright green leaves, resembling a Cedar. In early spring the branches are so thickly set with flowers that they appear as if robed in a fabric of pink, of soft and fluffy texture.

Dainty showy and refined, with an enchantment rare and füll.

Either of the Tamarisks, strong plants, prepaid, 25 cts. each; larger sizes, purchaser paying transportation, $25 \mathrm{cts}$. and $35 \mathrm{cts}$. each.

\section{Tecoma - The Trumpet Vines}

With abounding vigor and sturdy growth characterizing every phase of development, the Trumpet Vines present pictures of vital energy and strength of plant life that are inspiring. They a re very showy climbers, clinging to walls and trunks of trees by means of aërial rootlets, and blossom profusely for several weeks in summer. Few subjects so quickly and so pleasingly cover the canopies of arbors. When impatient of results, plant Trumpet Vines.

Tecoma grandiflora. Chinese Trumpet Vine. A high-climbing vine with numerous stout and spreading branches. Flowers in large terminal clusters, bright scarlet, freely produced and very showy. Superb. Hardy as far north as Tennessee and the District of Columbia.

T. radicans. AMERICAN TRUMPET VINE. A highclimbing vigorous vine with stout spreading branches. Flowers in large terminal clusters, orange-red within, bright scarlet on the outside, profusely borne and very showy. In many respects similar to the foregoing species, but possessing the quality of greater hardiness Withstands the winters of Missouri and Massachusetts.

Either of the Trumpet Vines, vigorous plants, prepaid, 25 cts. each; stronger vines, purchaser paying transportation, $25 \mathrm{cts}$. and $50 \mathrm{cts}$. each.

\section{Tilia . The Lindens}

Very few of us, perhaps, associate the Lindens with flowering trees, but, in truth, they are very beautiful during the summer blossoming season. The air about them is redolent of fragrance and melodious by the humming of bees. These hardy, noble trees are excellent for shade, both on the lawn and street.
Tilia americana. ANERICAN LIN1)Ex. Basswoon A large tree with a broad and shapely crown. Flowers creamy white, borne in great profusion. The heart-shaped deep green leaves fade in autumn with pleasung tones of yellow. Impressively grand.

T. europaea. EUROPEAN LINDEN LIME TREE, Like the last, a large and majestic tree, with a symmetrical broad crown. Flowers creamy white, very fragrant. The obliquely heart-shaped leaves are bright green, assuming tones of yellow and brown in autumn. Valuable for street planting.

Either of the Lindens, vigorous young plants, prepaid, $25 \mathrm{cts}$. each ; larger trees, purchaser paying transportation, $25 \mathrm{cts}$., $50 \mathrm{cts}$. and $75 \mathrm{cts}$. each.

My plants-fine ones-came several days ago in splendid condition. Thank you for the extra Clematis. Very truly, MrS. LeE Newrury, 666 Swiss Ave., Dallas, Texas, April 24, 1908 .

The case of plants which you shipped to :me on Appil 10, via Southern Railway and 1). L. \& W. Railroad, were delivered here safely on April 26. They were finely packed and arrived moist and in perfect condition. I am entirely satisfied with the filling of the order and consider it done not only justly, but generously. ROBERT
IV. ROGERS, Drew Theo. Seminary, Madison, N. J., 4-29-07.

Plants came in perfect order. Am delighted beyond expression. F. L. SeELy, publisher "Atlanta Georgian," Feb. 26 , 'o9.

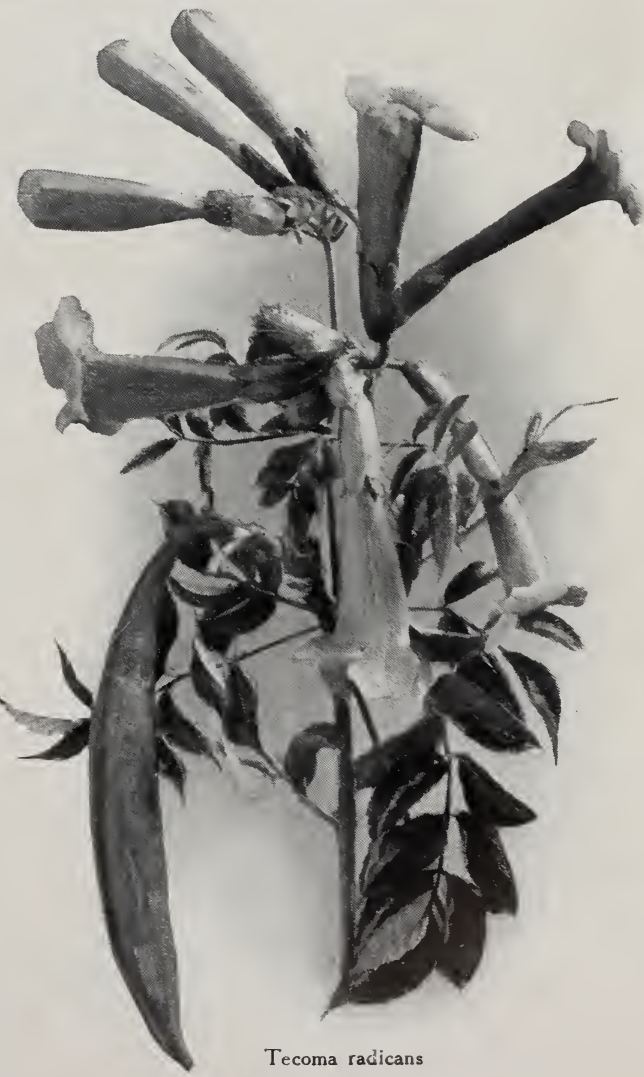




\section{BILTMORE NURSERY ' WRP}

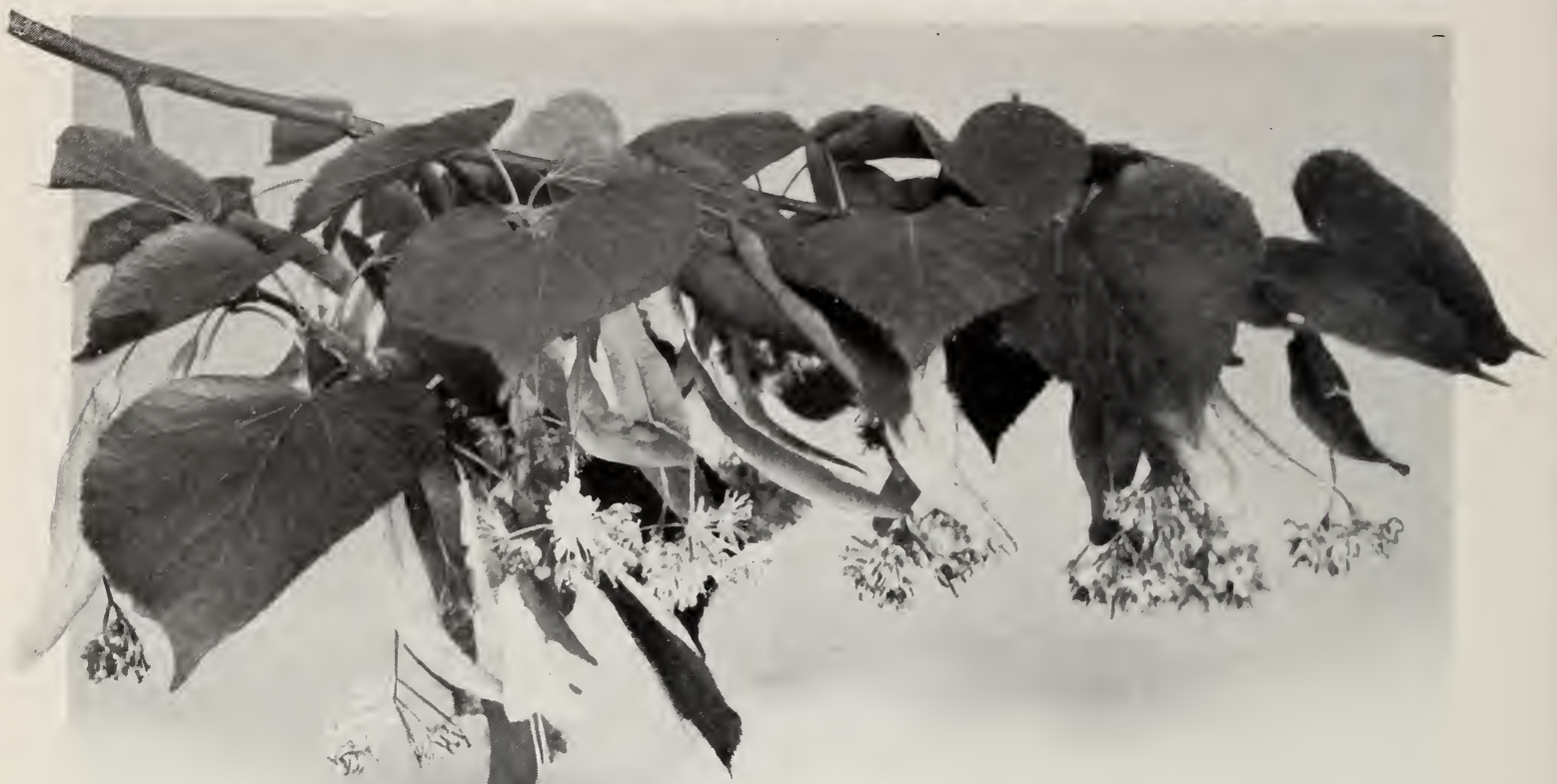

Tilia americana (see page 57 )

and is hardy with protection from cold winds as far north as Missouri and Massachusetts. Blossoms usually both in spring and fall, or in California, almost throughout the season. Thrifty plants, prepaid, $25 \mathrm{cts}$. each; larger sizes, purchaser paying transportation, $25 \mathrm{cts}$. and $35 \mathrm{cts}$. each.

Ulex europaeus. Furze, Gorse, or Whin. Dear to the hearts of those who knew in childhood's days a home beyond the Atlantic, is the Spiny Furze, with its verdant branches glowing with a wealth of yellow flowers. It is so quaint and curious, yet so sunny in its armour of defence, that no wonder memory lingers to its charms. It thrives in sandy or well-drained soils,

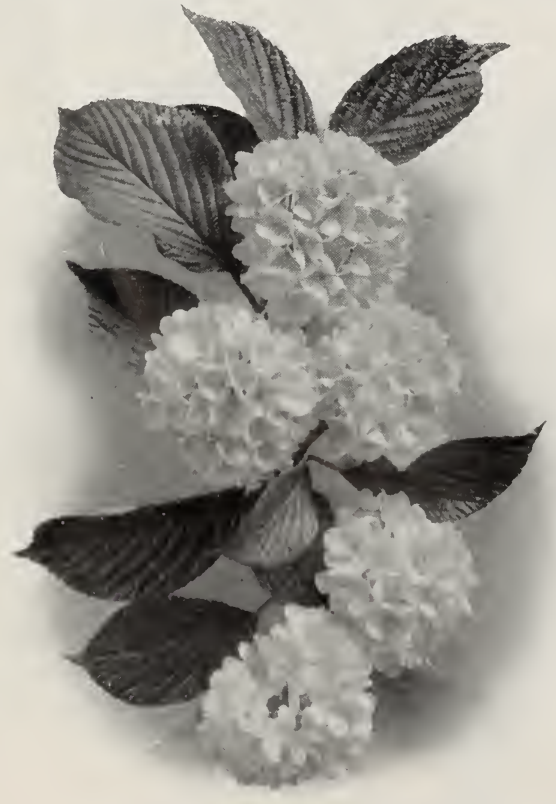

Viburnum tomentosum pl.catum (see page 59)

\section{Viburnum - The Black Haws, Arrow-woods and Snowballs}

Handsome, hardy shrubs and little trees, with showy flowers and foliage. They are not only strikingly attractive, when in flower, but several species produce large and profuse clusters of bright or glistening berries, and the foliage frequently assumes brilliant and intense color-tones in autumn. As specimen plants, the showier forms, like the Snowballs, have few rivals, and for grouping or massing, the humbler forms make possible many charming effects. The sterling qualities of these splendid plants are rapidly being recognized by discriminating planters both far and near.

Viburnum cassinoides. WITHE-ROD. A very hardy free-flowering shrub, in cultivation usually 4 to 8 feet tall. Flowers creamy or yellowish white, in broad flattopped clusters in late spring or early summer. Berries pink, changing to dark blue. Leaves dull green, fading with rich tones of purple and red. Splendid for grouping in the shrub borders.

V. dentatum. ARROw-woOD. A bushy shrub with upright branches, handsome and symmetrical, from \& to I2 feet tall. Flowers creamy white, in profuse flat topped clusters towards the end of spring. Leaves bright green, changing in autumn to ricli shades of purple and red. Berries blue-black. Showy and desirable.

V.lantana. IVAYFARING TREE. A large shrub or small tree with scurfy branches. usually growing to to 15 feet tall. Flowers white, disposed in dense flattopped clusters, usually with seven showy white rayflowers on the margins. Berries bright red, changing to black. Leaves deeply wrinkled, dark green. A splendid specimen plant. 


\section{BILTMORE, N.G. W W}

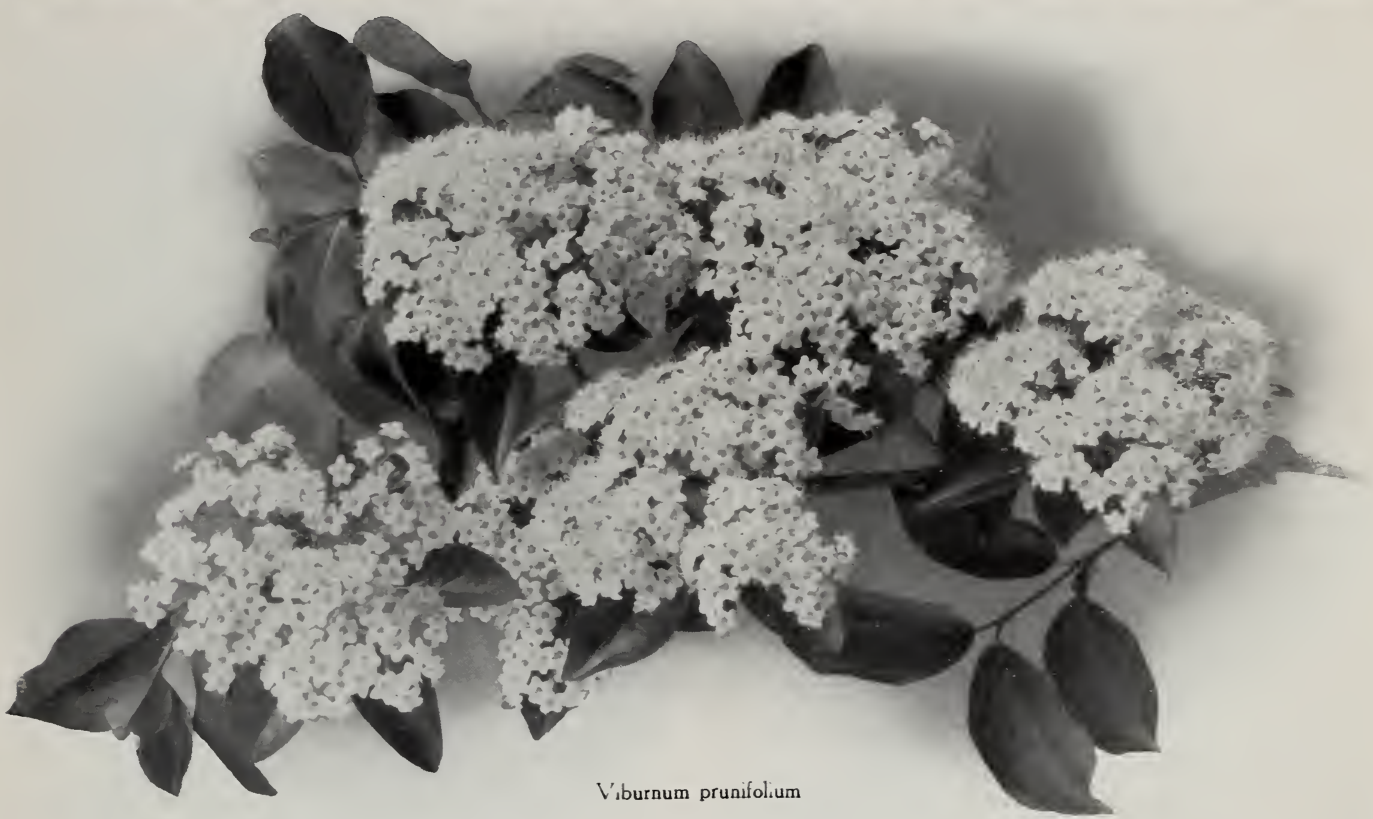

Viburnum, continued

Viburnum lentago. SheepberRy. NANyiberry. A remarkably symmetrical and decorative large shrub or small tree. Flowers creamy white, opening in spring, followed in autumn by red-stemmed clusters of black or dark blue berries. Leaves bronze-green as they unfold in earliest spring, at maturity bright shining green, turning red and orange in the fall. Very highly recommended, and rery beautiful.

V. opulus. High Bush CRANBERry. A tall shrub with upright and spreading branches, 8 to ro feet tall. Flowers white, disposed in flat-topped clusters in late spring, with many of the marginal flowers ray-like. The bright scarlet berries, persisting all winter, are wonderfully vivid and showy.

V. opulus sterile. SNOWBALL. GLELDER Rose. A grand hardy shrub with handsome showy flowers produced in large globular clusters. All of the flowers are sterile and radiant, and appear in numerous compact balls in spring. An old-time favorite, well known and justly popular. Strong plants, prepaid, I5 cts. each; larger sizes, purchaser paying transportation i5 cts., 25 cts. and 35 cts. each.

V. prunifolium. BLACK HAw. STAG Bush. A buchy tree with stiff, spreading branches. The creamy white flowers which deck the pliant twigs in spring in profuse bewilderment are succeeded in the autumn by showy red-stemmed clusters of glaucous blue berries. Leaves pale yellow-green as they unfold, dark green at maturity, turning brilliant scarlet or vinous red in autumn. Tery ornamental and splendid for a specimen plant.

V. tomentosum. SINGr.E-FrowERED JAPANESE SNOWBALL. The half has never been told of the glorious effect of this vigorous hardy shrub. Flowers white, produced in numerous flat-topped clusters, with the marginal sterile and radiant. Berries red, changing to bluish black. Leaves dark green with bronzy margins, very handsome. Height 6 to 8 feet. A splendid companion plant for the next following and more popular form.

V. tomentosum plicatum. JAPAxese Sxombal. L. The climax of the Snowballs! A handsome shrub with showy flowers and beautiful foliage. The large globose flower-clusters are 3 to 4 inches across, and consist wholly of sterile radiant flowers of purest white.
Very highly recommended. Hardy in Missouri and Massachusetts, but should be protected from piercing winds in colder sections. It would be difficult to find a shrub combining a greater number of points of real excellence.

Except where noted, any of the above, strong plants, prepaid, 25 cts. each; larger sizes, purchaser paying transportation, 25 cts., 35 cts. and 50 cts. each.

SPECIAL OFFER. A collection of six Viburnums, our selection of varieties, no two alike, but including two Snowballs, strong plants, prepaid, $\$ 1.25$; larger sizes, purchaser paying transportation, $\$ 1.25$ and $\$ 2.25$.

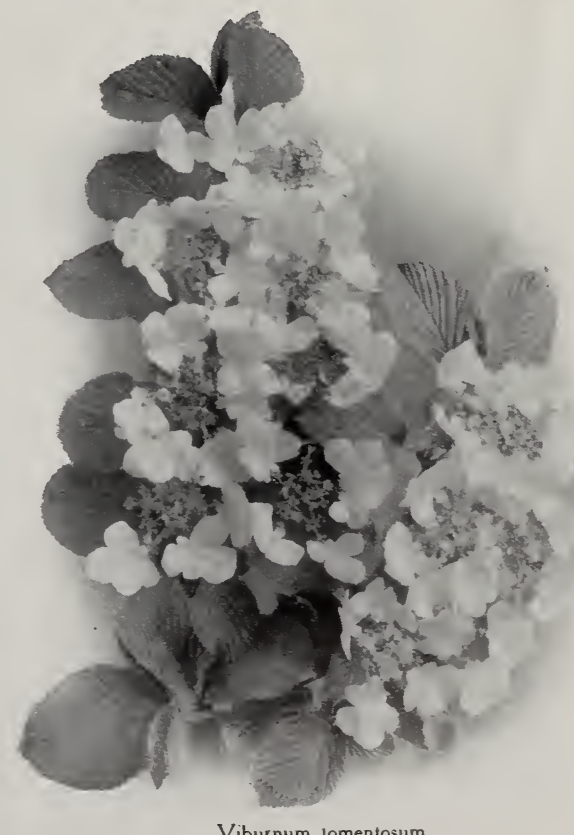

Viburnum lomentosum 


\section{BILTMORE NURSERY X YE}

\section{Vitex}

Vitex agnus castus. Chaste TrEe. An extremely showy shrub or small tree with wide-spreading branches. Hardy as far north as Kentucky and Pennsylvania, or with protection from cold winds it may be grown in colder localities. Flowers lilac or violet-purple, disposed in dense terminal racemes in late summer. All parts of the plant exhale an agreeable aromatic odor when bruised. Really charming. Vigorous plants, prepaid, 25 cts. each; larger sizes, purcliaser paying transportation, $25 \mathrm{cts}$. and $50 \mathrm{cts}$. each.

\section{Wistaria - The Wistarias}

A contributor to a recent issue of a horticultural journal tritely states : "A porch without vines is like a house without occupants." Not only does the wonderful grace and beauty of well-placed vines add to the comfort and enjoyment of the home, but they give a soft, artistic effect and animation to the architectural design that no other treatment can produce. And of all the flowering vines, the grand Wistarias, with their gorgeous blossoms, scarcely have a peer. We confidently recommend them $f(r$ they are beyond a doubt among the best and hardiest of ornamental vines.

Wistaria chinensis. ChINese IVISTARIA. A rapidgrowing tall vine with feathery foliage and handsome flowers. The glorious blossoms, radiant in their inherent Oriental splendor, are profusely borne in long drooping clusters in mid-spring and gleam in soft tones of violet-purple. Very showy and desirable, and decidedly one of the best.

W. chinensis alba. White IVIstaRia. A form of the preceding with pure white flowers.

W. chinensis flore pleno. DOUBLE-FLOWERED WISTARIA. A free-flowering variety with very double

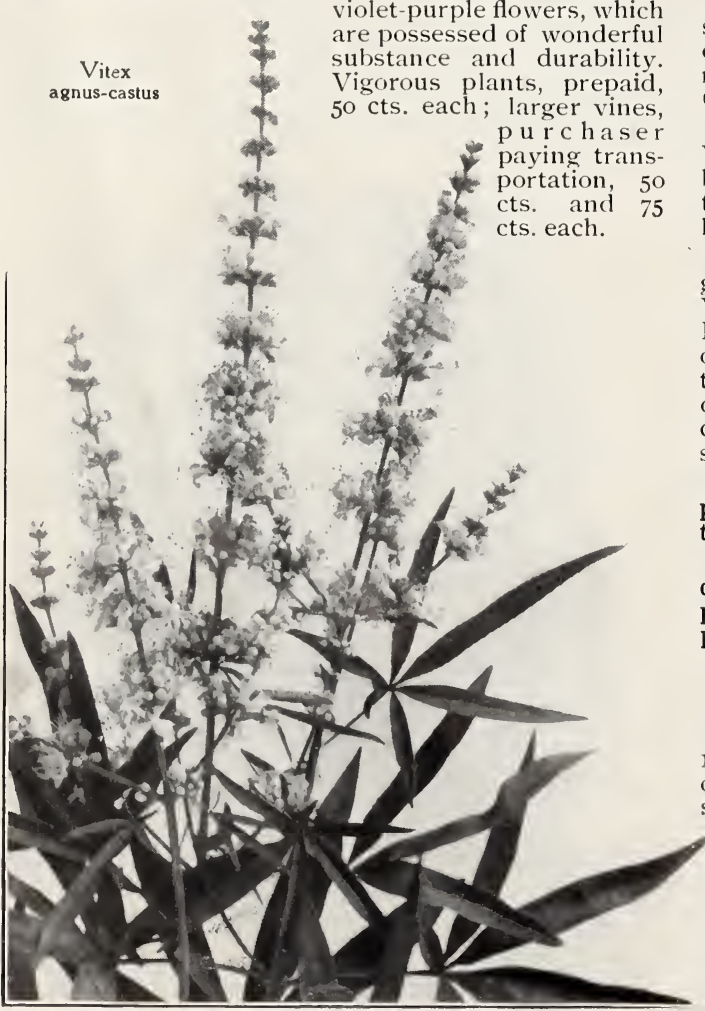

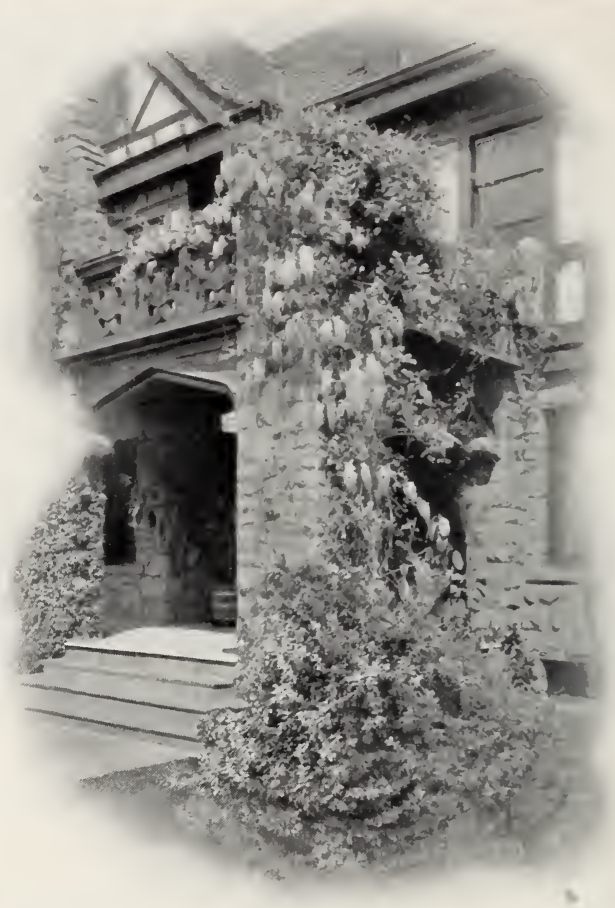

Wistarıa chinensis

Wistaria, continued

Wistaria frutescens. ANERICAN IVISTAR1A. A tall and slender vine, producing an airy light shade. Flower: deep lilac-purple, borne in numerous, dense, short racemes, blossoming about three weeks later than the Chinese Wistaria.

W. macrostachys. LARGE-FLOWERED AMERICAN WISTARIA. A thrifty tall vine with graceful drapery of bright green foliage. Flowers in drooping clusters to 8 inches long, varying in color from lilac-purple to light blue; very showy.

W. multijuga. JAPANESE W1STARIA. A vigorous tallgrowing vine with feathery foliage. This is the famous Vistaria concerning which travelers in the Flowery Kingdom have written in words of superlative degree of its exquisite grace and beauty, yet only to admit that its subtle charm eluded true analysis. The wonderful light purple flowers are borne in loose pendent clusters from I to 3 feet long, and are lavish in profusion towards the end of spring. Exceptionally good.

Except where noted, any of the Wistarias, strong plants, 25 cts. each; larger sizes, purchaser paying transportation, $25 \mathrm{cts}$. and $50 \mathrm{cts}$. each.

SPECIAL OFFER. A collection of three Wistarias, different varieties of our own selection, strong plants, prepaid, 50 cts.; larger vines, purchaser paying transportation, $50 \mathrm{cts}$. and $\$ 1$.

\section{Xanthoceras}

Xanthoceras sorbifolia. CHINESE FlowERING CHLSTNUT. A rare and handsome free-flowering small tree or large shrub, providing a galaxy of floril tribute in spring. While relatively hardy, enduring temperature below zero, it is so infrequent in cultivation that it is best to afford protection from cold winds when planted in the colder sections of the North. Flowers in long racentes, pure white, with an orange blotch at the base of each petal. One of the most beautiful of ornamentals. Thrifty plants, prepaid, 25 cts. each: larger sizes, purchaser paying transportation, 25 cts. and $50 \mathrm{cts}$. each. 


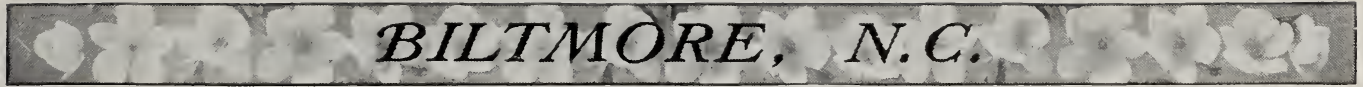

\section{Zenobia}

Zenobia cassinifolia (Andromeda speciosa). ZeNobia. Resembling huge, dense clusters of the flowers of the Lily-of-the-Valley, so wax-like and dainty in their purity, the nodding blossoms of this charming shrub fairly startle one, so unusual and yet so pleasing is their greeting. The Zenobia is a small shrub with upright, often curving branches, and is hardy as far north as Missouri and Massachusetts. In autumn the foliage fairly glows in the richest shades of crimson. Remarkably beautiful. V'igorous plants, prepaid, 50 cts. each: larger sizes, purchaser paying transportation, 50 cts. and $75 \mathrm{cts}$. each.

If the foregoing pages have failed to contain descriptions or illustrations of the plants which you have thought to find, we would again call attention to the first and second paragraphs of the introduction on page 3 . This booklet is confessedly an abridged catalogue, and contains only, as its title would imply, the more important forms of "Flowering Trees and Shrubs" Again we invite patrons or prospective buyers to apply for our complete catalogue, in which is described, and in many instances illustrated, a large and remarkably complete line of ornamental plants. This large book, which established a new record in nursery literature, is printed on fine book paper; has been carefully written and is illustrated from specially made photographs used by no other nursery. No promiscuous distribution to uninterested persons is practicable; but we will gladly send a copy free of all charge to any one who owns a home, or expects to own one soon and wishes to plan the planting of its grounds.

The shrubs you shipped me recently came in good condition, thanks to their excellent packing.- HARRISON ROBERTSON, 234 E. College St., Louisville, Ky., April 26, 1908.

The stock you sent the Quincy Boulevard and Park Assocition last spring gave good satisfaction and you may look for another order.-Ô. I. WW HEELER, Quincy, Ill., Nov. 30, 1908 .

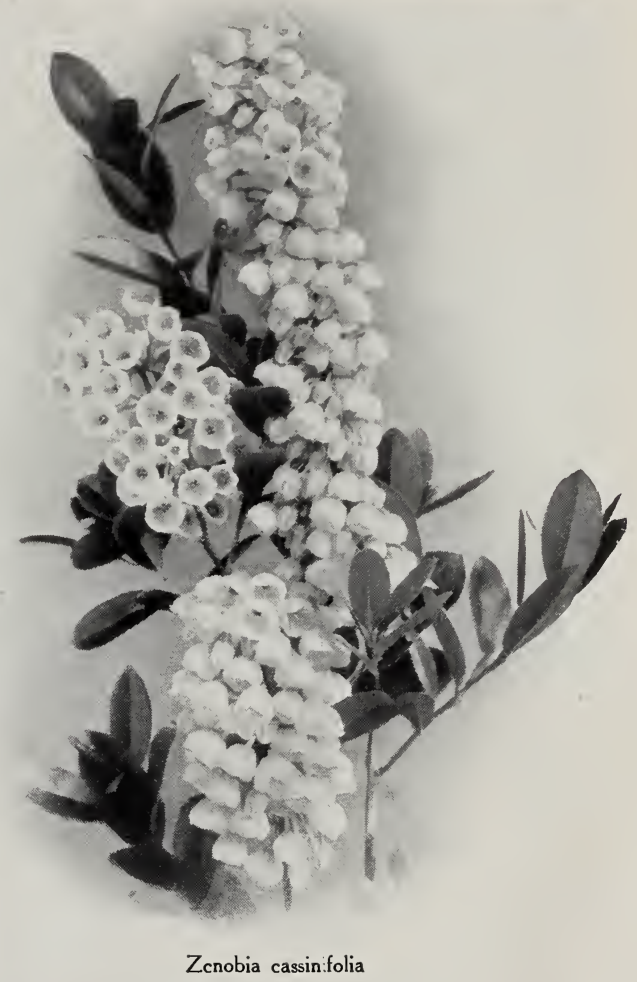

Received plants in good condition. You certainly deserve much credit for the way in which you pack vour goods. Silas Reynolds, Mt. Carroll, I11., April $28,1908$.

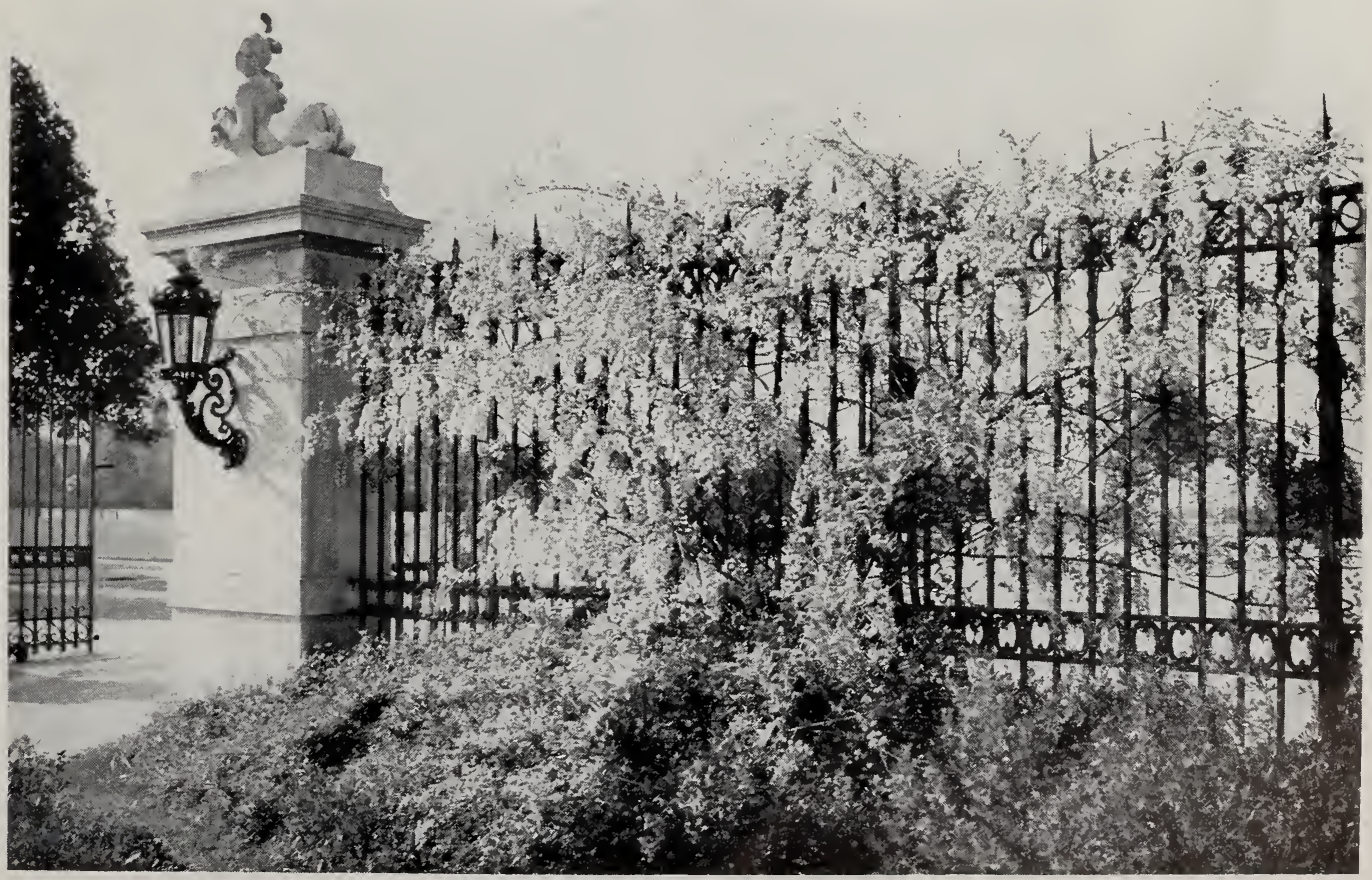

The airy splendor of Wistaria chinensis (see page 60) 


\section{BILTMORE NURSERY}

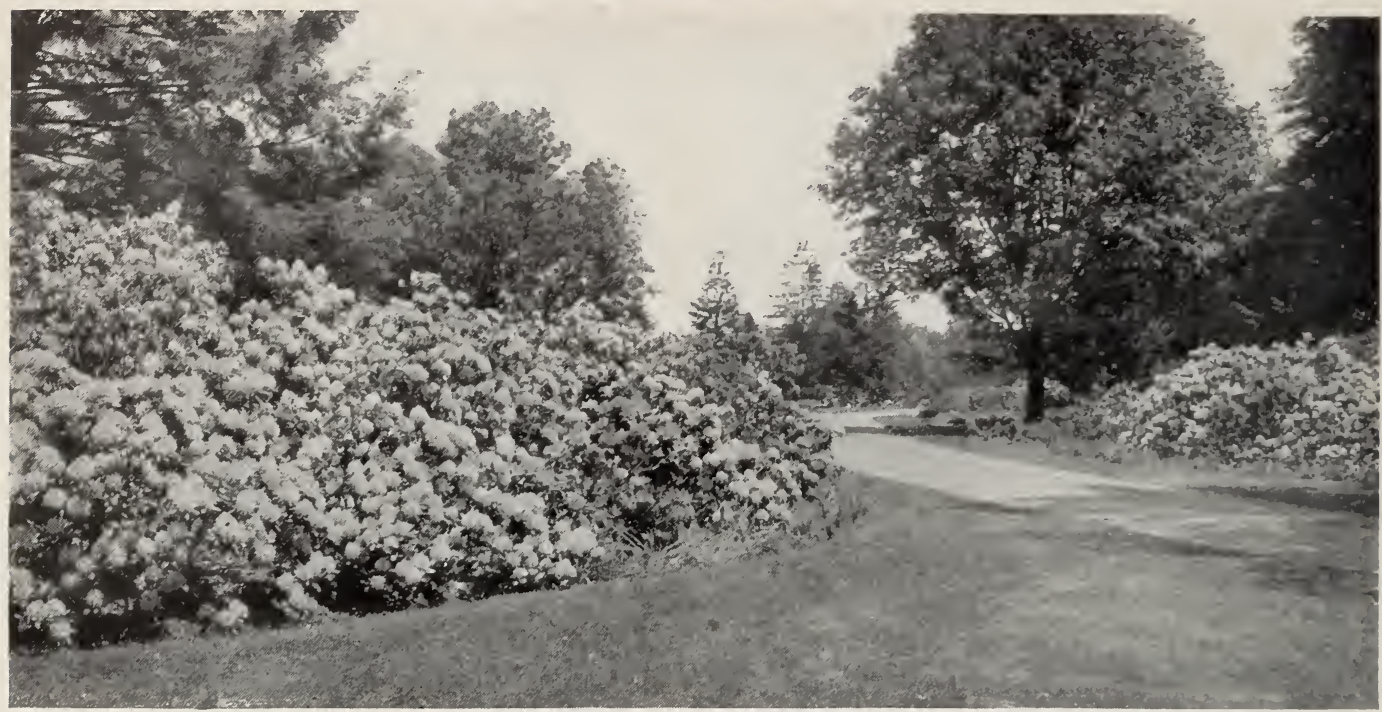

\section{The Biltmore Sets of Flowering Trees and Shrubs}

The collections embrace some of the showiest and best of ornamentals, and are offered with a view of aiding the novice in securing flowering trees and shrubs that are famous for their beauty. For convenience in ordering, patrons may designate by key letter as indicated.

\section{Twelve Hardy Flowering Trees, Set "A"}

AEsculus hippocastanum. Horse-Chestnut. Amelanchier botryapium. June Berry.

Catalpa speciosa. WVestern Catalpa.

Cerasus hortensis. Flowering Cherry.

Cercis canadensis. Red Bud, or Judas Tree.

Cornus florida. White-flowering Dogwood.

Crataegus monogyna plena. Double-flowered Hawthorn. Laburnum vulgare. Golden Chain.

Magnolia stellata. Starry Magnolia.

Malus ioensis bechteli. Double-flowering Crab.

Persica vulgaris plena. Double-flowering Peach.

Robinia pseudacacia. Black Locust.

One each of the above, twelve in all, thrifty young trees, prepaid, $\$ 3.75$; larger sizes, purchaser paying transportation, $\$ 3.75$ and $\$ 5$.

\section{Six Hardy Flowering Trees, Set "B'}

Cerasus hortensis. Flowering Cherry.

Cercis canadensis. Red Bud, or Judas Tree.

Cornus florida. White-flowering Dogwood.

Crataegus monogyna plena. Double-flowered Hawthorn. Laburnum vulgare. Golden Chain.

Malus ioensis bechteli. Bechtel's Flowering Crab.

One each of the above, six in all, thrifty young trees, prepaid, $\$ 1.65$; larger sizes, purchaser paying transportation, $\$ 1.65$ and $\$ 2.50$.

My previous experience with your nursery has been so sat is factory that I hope to give a considerable order in Septemher. Truly yours, IVILBUR DUBoIs, Arusby Place, Madisonville, Ohio, August 27, 1908 .

\section{Six Flowering Trees for the South, Set "G"}

Albizzia julibrissin. Mimosa Tree.

Magnolia grandiflora. Southern Magnolia.

Mohrodendron dipterum. Snowdrop Tree.

Paulownia imperialis. Empress Tree.

Vitex agnus=castus. Chaste Tree.

Xanthoceras sorbifolia. Chinese Flowering Chestnut.

One each of the above, six in all, thrifty young trees, prepaid, $\$ 1.65$; larger sizes, purchaser paying transportation, $\$ 1.65$ and $\$ 2.50$.

\section{Six Hardy Flowering Shrubs} with Evergreen Leaves, Set "D'

Calluna vulgaris. Scotch Heather.

Daphne cneorum. Garland Flower.

Kalmia latifolia. Mountain Laurel.

Leucothoe catesbaei. Catesby's Leucothoe.

Pieris floribunda. Mountain Fetter Bush.

Rhododendron maximum. Rose Bay.

One each of the above, six in all, vigorous plants, prepaid, \$3; larger sizes, purchaser paying transportation, $\$ 3$ and $\$ 4$.

\section{Six Flowering Shrubs with Evergreen Foliage for the South, Set "E"'}

Abelia grandiflora. Hybrid Abelia.

Gardenia jasminoides. Cape Jasmine.

Jasminum officinale. True Jasmine, or Jessamine.

Nerium oleander. Oleander.

0smanthus fragrans. Fragrant Olive.

Rosa laevigata. Cherokee Rose.

One each of the above, six in all, vigorous plants, prepaid, $\$ 1.35$; larger sizes, purchaser paying transportation, $\$ 1.35$ and $\$ 2$. 


\section{Twenty-five Hardy Flowering Shrubs, Set "F"}

Butneria florida. Strawberry Shrub. Clethra alnifolia. Sweet Pepper Bush. Cydonia japonica. Japanese, or Flowering Quince. Deutzia crenata plena. Double-flowered Deutzia. Deutzia gracilis. Slender Deutzia.

Diervilla florida. IVeigelia.

Exochorda grandiflora. Pearl Bush.

Forsythia suspensa. Golden Bell.

Hibiscus syriacus. Rose of Sharon.

Hydrangea pan culata grandiflora. Large-flowered

Hydrangea.

Kerria japonica. Globe Flower.

Lonicera fragrantissima. Fragrant Honeysuckle.

Lonicera tatarica. Tartarian Honeysuckle.

Philadelphus coronarius. Mock Orange.

Philadelphus latifolius. Broad-leaved Mock Orange.

Prunus japonica. Flowering Almond.

Rhodotypos kerrioides. White Kerria.

Spiraea bumalda Anthony Waterer. Crimson Spirea.

Spiraea prunifolia plena. Bridal Wreath.

Spiraea vanhouttei. Van Houtte's Bridal Wreath.

Syringa chinensis. Rouen Lilac.

Syringa vulgaris. Common Lilac.

Tamarix parviflora. Tamarisk.

Viburnum opulus sterile. Snowball, or Guelder Rose Viburnum tomentosum plicatum. Japanese Snowball.

One each of the above, twenty-five in all, thrifty young shrubs, prepaid, $\$ 3.50$; larger sizes, purchaser paying transportation, $\$ 3.50$ and $\$ 5$.

\section{Twelve Hardy Flowering Shrubs, Set "G",}

Cydonia japonica. Japanese, or Flowering Quince. Deutzia crenata plena. Double-flowered Deutzia. Diervilla florida. Weigelia.
Twelve Hardy Flowering Shrubs, continued Forsythia suspensa. Golden Bell.

Hibiscus syriacus. Rose of Sharon.

Hydrangea paniculata grandiflora. Large-flowered $\mathrm{H}$. drangea.

Philadelphus coronarius. Mock Orange.

Prunus japonica. Flowering Almond.

Spiraea bumalda Anthony Waterer. Crimson Spirea.

Spiraea vanhouttei. Van Houtte's Bridal Wreath.

Syringa vulgaris. Common Lilac.

Viburnum tomentosum plicatum. Japanese Snowball.

One each of the above, twelve in all, vigorous young shrubs, prepaid, $\$ 1.65$; larger sizes, purchaser paying transportation, $\$ 1.65$ and $\$ 2.50$.

\section{Six Flowering Shrubs for the South, Set "H"}

Buddleia variabilis. Sweet-scented Buddleia.

Caryopteris mastacanthus. Blue Spirea.

Chimonanthus fragrans. Oriental Sweet Shrub.

Cytisus scoparius. Scotch Broom.

Hydrangea hortensis. Japanese Hydrangea.

Lagerstroemia indica. Crape Myrtle.

One each of the above, six in all, vigorous young plants, prepaid, $\$ 1$; larger sizes, purchaser paying transportation, $\$ 1$ and $\$ 1.75$.

\section{Seven Hardy Vines, Set " K"}

Clematis hybrida jackmanni. Large-flowering Clematis. Clematis paniculata. Japanese Clematis.

Lonicera japonica. Japanese Honeysuckle.

Lonicera sempervirens. Coral Honeysuckle.

Tecoma radicans. Trumpet Vine.

Wistaria chinensis. Chinese Wistaria.

Wistaria multijuga. Japanese Wistaria.

One each of the above, seven in all, strong plants, prepaid, $\$ 1.50$; larger sizes, purchaser paying transportation, $\$ 1.50$ and $\$ 2.50$.

The plants came yesterday and in fine condition. I shall lemember where to get good plants or shrubs in the future:H. W. RoBERTs, Ottumwa, Iowa, April 27, 1907.

I wish to express my appreciation of the nursery stock you sent me on my last order, and also of the way in which it was packed.-Al'stin T. PARK, The Rediands National Bank, Redlands, Cal., April 13,1908.

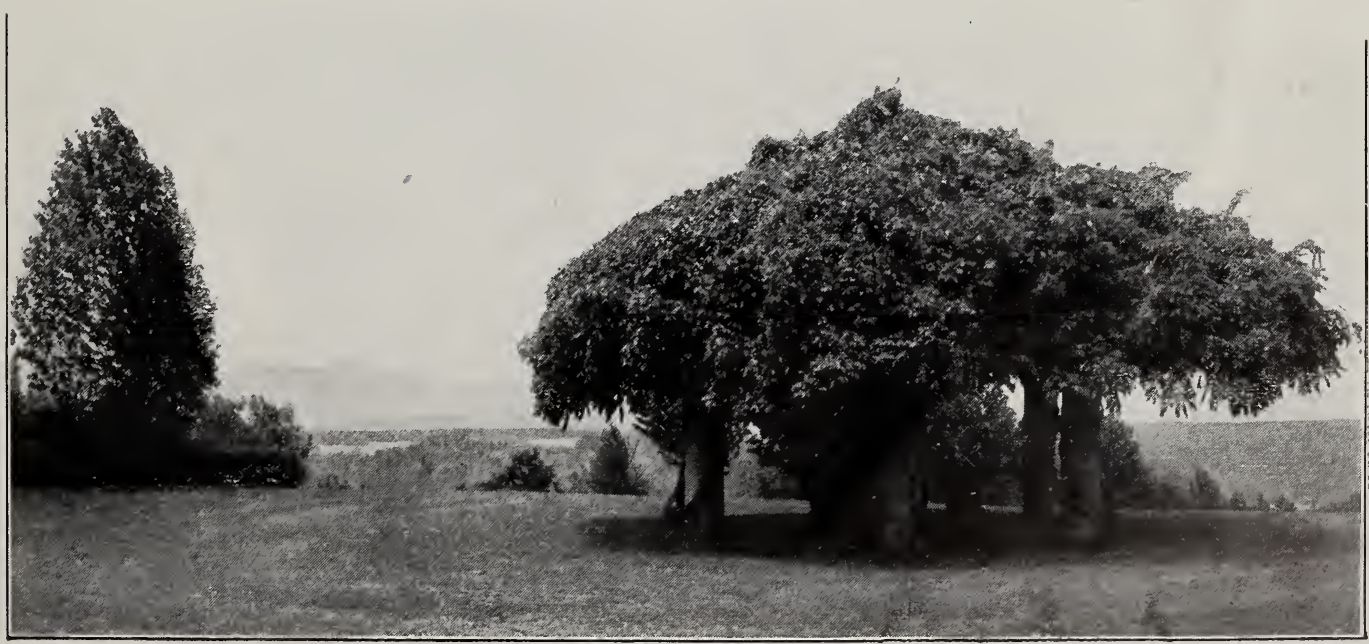

An arbor of Wistaria (see page 60) 


\section{INDEX}

\begin{tabular}{|c|c|c|}
\hline belia . & $\ldots \ldots \ldots \ldots \ldots, \ldots$ & \\
\hline 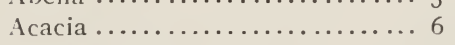 & 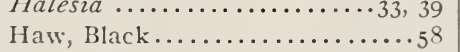 & $\begin{array}{l}\text { Quince, Flowering .............. } \\
\text { Quince, Japanese .............. }\end{array}$ \\
\hline acia, Rose................ & Hawthorn .................. & \\
\hline e, Carolina.............. & $\ldots \ldots \ldots \ldots \ldots \ldots \ldots \ldots \ldots \ldots \ldots$ & aspberry, Flowering $\ldots \ldots \ldots \ldots 42$ \\
\hline ond, Dwarf $\ldots \ldots \ldots \ldots \ldots \cdot 3^{8}$ & 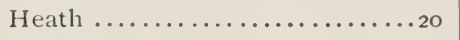 & …, \\
\hline thaca...................23 & , Scotch $\ldots \ldots \ldots \ldots \ldots \cdot$ I $_{0}$ & Red Root .................. I 2 \\
\hline ndromeda..........2s, 37, 38,6 I & Iercules' Club ............. 7 & Rhododendron $\ldots \ldots \ldots \ldots \ldots \ldots \ldots$ \\
\hline a Tree..$\ldots \ldots \ldots \ldots \ldots \ldots$ & ills of Snow...............23 & Rose $\ldots \ldots \ldots \ldots \ldots \ldots \ldots+3$ \\
\hline$\cdots \cdots \cdots \cdots \cdots \cdots \cdots 5^{8}$ & e................29 & Rose Bay.................. 39, 40 \\
\hline $\lg \ldots \ldots \ldots \ldots \ldots+22$ & nut................ 5 & Rose, Guelder .................. 59 \\
\hline n................53 & a $\ldots \ldots \ldots \ldots \ldots \ldots+23$ & Rose of Sharon ................23 \\
\hline spen $\ldots \ldots \ldots \ldots \ldots \cdots \cdots \cdots \cdots \cdot 3^{8}$ & limbing......... 8 , 52 & n Tree $\ldots \ldots \ldots \ldots \ldots \ldots \ldots, \ldots 3$ \\
\hline zalea $\ldots \ldots \ldots \ldots \ldots \ldots \ldots \ldots \ldots, 7$ & $\ldots \ldots \ldots \ldots \ldots$ & Berry ............ \\
\hline arberry $\ldots \ldots \ldots \ldots \ldots \ldots \ldots, 9$ & Bush ................ & 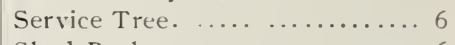 \\
\hline$\because \ldots \cdots \cdots+\cdots \cdots+57$ & $\cdots \cdot$ & $\cdots \ldots \ldots \ldots \ldots$, \\
\hline inese ............. I I & $\ldots \ldots \ldots \ldots$ & ….......59 \\
\hline$\cdots \cdots \cdots \cdots \cdots+\cdots 5$ & 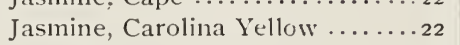 & $\ldots \ldots \ldots+33$ \\
\hline$\ldots \ldots \ldots \ldots \ldots \ldots \ldots$ & . & , \\
\hline$\ldots \ldots \ldots \ldots \ldots+54$ & & Tree............. 33 \\
\hline$\ldots \ldots \ldots \ldots \cdots \cdots \cdots \cdots+17$ & 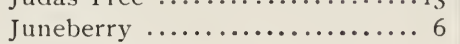 & 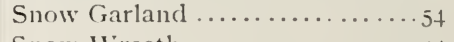 \\
\hline$h \ldots \ldots \ldots \ldots, 53$ & & $\cdots \cdots \cdots \cdots 34$ \\
\hline$\cdots \cdots \cdots \cdots \cdots \cdots \cdots \cdots \cdots \cdots$ & $\cdots \cdots \cdots 4^{r}$ & 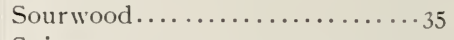 \\
\hline$\ldots \ldots \ldots+\ldots, \ldots+\cdots, 9$ & $\ldots \ldots \ldots \ldots \ldots$ & \\
\hline$\ldots \ldots \ldots \ldots \ldots \ldots \ldots \ldots \ldots$ & & $\cdots \cdots \cdots \cdots \cdots \cdots \cdots+\mathrm{II}_{\mathrm{I}}$ \\
\hline 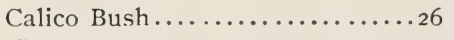 & 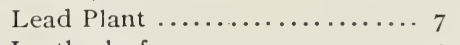 & $\cdots \cdots \cdots \cdots \cdots \cdots \cdots+59$ \\
\hline$s \ldots \ldots \ldots \ldots \ldots \ldots$ ro & $\ldots \ldots \ldots \ldots \ldots \ldots 14$ & $\cdots \cdots$ \\
\hline$\ldots \ldots \ldots \ldots \ldots \ldots \ldots \ldots$ I $\mathrm{r}$ & 2 $\ldots \ldots \ldots \ldots \ldots \ldots \ldots$ & ort ..... \\
\hline$\ldots \ldots \ldots \ldots \ldots \ldots \ldots \ldots$ 14 & 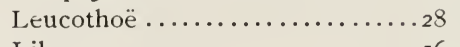 & $\cdots 55$ \\
\hline (n... & $\ldots \ldots \ldots \ldots \ldots \cdots \cdots+5^{6}$ & $\cdots 10$ \\
\hline$\ldots \ldots \ldots \ldots 6,60$ & $\ldots \ldots \cdots \cdots \cdots \cdots \cdots \cdots+57$ & $\cdots \cdots \cdot 55$ \\
\hline$\ldots \ldots \ldots \ldots \ldots \ldots \ldots \ldots \ldots$ & $\cdots \cdots \cdots \cdots \cdots \cdots \cdots \cdots+57$ & $\cdots \cdots \cdots$ \\
\hline .................39 & $\cdots \cdots \cdots \cdots \cdots \cdots+4^{I}$ & \\
\hline$\ldots \ldots \ldots \ldots \ldots$ II & & \\
\hline e Flowering ....6o & $\cdots \cdots \cdots$ & \\
\hline rubby $\ldots \ldots \ldots \cdot \ldots \cdot 38$ & 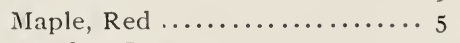 & \\
\hline , $\ldots \ldots \cdots \cdots \cdots \cdots$ & 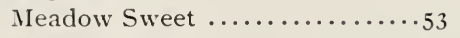 & $\cdots$ \\
\hline$\ldots \ldots \ldots \ldots \ldots$ & $\ldots \ldots \ldots \ldots \ldots \ldots 6$ & …... \\
\hline $19 \ldots \cdots \cdots \cdots \cdots \cdot 32$ & $\cdots \cdots \cdots \cdots \cdots \cdots \cdots+36$ & $\cdots \cdots \cdots+3$ \\
\hline gh Bush ...........59 & .27 & e.......... \\
\hline$\cdots \ldots+\ldots+\cdots \cdots+9$ & . I 8 & Tulip Tree...$\ldots \ldots \ldots \ldots$ \\
\hline ring $\ldots \ldots \ldots \cdots+1$ & n.............. & \\
\hline & & \\
\hline & te & \\
\hline & & 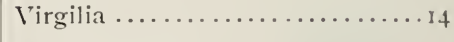 \\
\hline 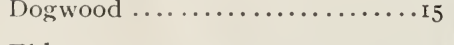 & & \\
\hline & $\cdot 34$ & \\
\hline & Olive, Russian ................. & \\
\hline & & \\
\hline & .35 & \\
\hline & $g \ldots \ldots \cdots \cdots \cdots \cdots \cdots+36$ & e. \\
\hline & & ........ \\
\hline$\cdots 17$ & $\ldots 11$ & \\
\hline$\cdots 17$ & & \\
\hline$\ldots 27$ & & \\
\hline$\cdots 2 \mathrm{I}$ & & \\
\hline$\cdots 27$ & & \\
\hline$\ldots \ldots \ldots \cdots \cdots$ & 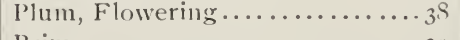 & \\
\hline & & \\
\hline & & \\
\hline & & \\
\hline
\end{tabular}




\section{ORDER}

THIS BLANK MATERIALLY AIDS IN FILLING YOUR ORDER PROMPTLY AND ACCURATELY

\section{BILTMORE NURSERY Biltmore, North Carolina}

Send

State if you have selected prepaid sizes of plants, or those upon which you will assume transportation charges

To

P. O. Box, Street

or Rural Delivery

Post Office

County

State

Name of Railway

Station or

Express Office

Only when different from Post Office

Forward Now or About

The prices in the Catalog are net. To avoid confusion, please extend the price of each item.

Diaft

P. O. or Exp. Order

Stamps
Date

AMOUNT ENCLOSED

Cash.

If goods are wanted by express

C. O. D., 25 per cent of the amount of the order must be paid in advance.

\section{RECORDED}

\begin{tabular}{c|c|c|c|c}
\hline \hline QUANTITY & NAME OF PLANTS & \multicolumn{2}{c}{ PRICE } \\
\hline & & Dollars & Cenis \\
\hline & & & & \\
\hline
\end{tabular}




$$
\text { (15) }
$$$$
\text { * }
$$ 


\section{BILTMORE NURSERY}

Biltmore, North Carolina 